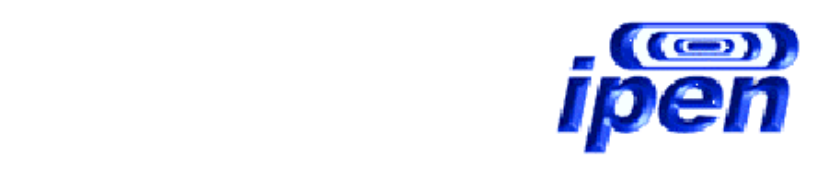

INSTITUTO DE PESQUISAS ENERGÉTICAS E NUCLEARES

"AUTARQUIA ASSOCIADA À UNIVERSIDADE DE SÃO PAULO"

\title{
PERSPECTIVAS DA GERAÇÃO DE CRÉDITOS DE CARBONO COM BASE NA OBTENÇÃO DE UM FERTILIZANTE - APROVEITAMENTO DE RESÍDUOS DE BIOMASSA DA AGRICULTURA BRASILEIRA
}

Caterina Velleca Bernardi

Tese apresentada como parte dos requisitos para obtenção do Grau de Doutor em Ciências na Área de Tecnologia Nuclear - Aplicações.

Orientadora:

Profa. Drª. Fátima Maria Sequeira de Carvalho

São Paulo 


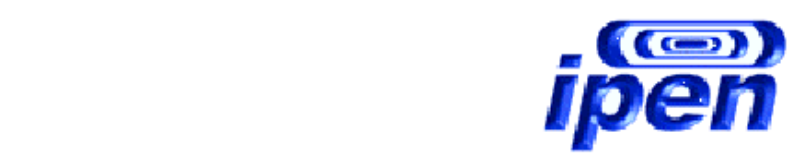

INSTITUTO DE PESQUISAS ENERGÉTICAS E NUCLEARES

"AUTARQUIA ASSOCIADA À UNIVERSIDADE DE SÃO PAULO”

\title{
PERSPECTIVAS DA GERAÇÃO DE CRÉDITOS DE CARBONO COM BASE NA OBTENÇÃO DE UM FERTILIZANTE - APROVEITAMENTO DE RESÍDUOS DE BIOMASSA DA AGRICULTURA BRASILEIRA
}

Caterina Velleca Bernardi

\begin{abstract}
Tese apresentada como parte dos requisitos para obtenção do Grau de Doutor em Ciências na Área de Tecnologia Nuclear - Aplicações.
\end{abstract}

Orientadora:

Prof ${ }^{\text {a }}$ Drª. Fátima Maria Sequeira de Carvalho

São Paulo 


\section{AGRADECIMENTOS}

Agradeço, em primeiro lugar, aquele Ser Supremo que sempre atendeu, da melhor forma, todas as minhas inúmeras preces, colocando em meu caminho desafios na proporção e intensidade que eu pude conquistar.

Agradeço, com todo amor e carinho, aos meus pais, Angela e Nunzio, cujo esforço e trabalho que, incondicionalmente tiveram em toda sua vida, me levaram a alcançar o degrau em que estou.

Agradeço também aos meus professores e colegas do programa de PósGraduação, pois cada um trouxe um ensinamento único à minha vida.

Agradeço a colaboração da Dra. Eliana Maria Arico pelo valioso auxílio e apoio dado nas análises realizadas no composto obtido.

Agradeço especialmente à minha querida e paciente orientadora Fátima Maria Sequeira de Carvalho, de quem tenho muito carinho e que entre outras coisas me ensinou a acreditar que tudo é possível.

E agradeço, com muita emoção, ao meu amado marido Paulo pelo amor incondicional, pela presença, confiança, apoio e inabalável fé e força em persistir que me transmitia em cada sorriso e em cada palavra. A ti o agradecimento especial pelo constante apoio e incentivo, e por estar sempre ao meu lado na trilha desta vida. 
"Em relação ao meio ambiente, às vezes penso que estamos como em 1939, quando o mundo todo sabia que havia a iminência de uma guerra mundial, mas mesmo assim ninguém se dava por convencido" 


\title{
PERSPECTIVAS DA GERAÇÃO DE CRÉDITOS DE CARBONO COM BASE NA OBTENÇÃO DE UM FERTILIZANTE - APROVEITAMENTO DE RESÍDUOS DE BIOMASSA DA AGRICULTURA BRASILEIRA
}

\author{
Caterina Velleca Bernardi
}

\section{RESUMO}

Neste trabalho, cujo enfoque é inédito na literatura, apresentam-se as principais diretrizes para a implementação de um Mecanismo de Desenvolvimento Limpo, bem como as possibilidades de geração de Redução Certificada de Emissão e sua valoração. Por meio de sistemas adequados, indicados em literatura, estimaram-se as quantidades de gás carbônico que poderiam ser obtidos, elegendo-se para este trabalho, o processo de gaseificação de resíduos de biomassa em algumas culturas agrícolas brasileiras.

Em relação ao gás carbônico gerado no processo sugere-se, para avaliar a obtenção de créditos de carbono, que sua captura seja feita através da sua fixação na produção de um fertilizante, que teve seu valor estimado no mercado.

Para comprovar essa possibilidade fizeram-se experimentos em escala laboratorial, retendo-se $\quad \mathrm{O}^{\mathrm{CO}_{2}} \mathrm{em}$ hidróxido de amônio. Análises termogravimétricas, espectroscopia no infravermelho, de difração de raios- $\mathrm{X} e$ $\mathrm{CHN}$ comprovaram a obtenção do bicarbonato de amônio. Para os valores numéricos foram consultadas nas bibliografias referentes, as culturas agrícolas brasileiras com índices de produção de resíduos conhecidos, estabelecendo-se então uma base de dados numéricos para a formação dos valores correspondentes.

Os resultados deste trabalho permitem afirmar que existe uma grande potencialidade para o aproveitamento dos gases resultantes da gaseificação dos resíduos de biomassa, principalmente do gás carbônico na produção de um fertilizante e, com a possibilidade de implementação de um Mecanismo de Desenvolvimento Limpo no país. 


\title{
PERSPECTIVES OF THE GENERATION OF CARBON CREDITS ON THE BASIS OF THE ATTAINMENT OF A FERTILIZER - EXPLOITATION OF RESIDUES OF BIOMASS OF BRAZILIAN AGRICULTURE
}

\author{
Caterina Velleca Bernardi
}

\begin{abstract}
In this work, whose approach is unknown in literature, the main lines of direction for the implementation of a Mechanism of Clean Development are presented, as well as the possibilities of generation of Certified Reduction of Emission and its valuation.

By means of adjusted systems, indicated in literature, the approach amounts of carbonic gas had been raised that could be gotten, choosing itself for this work, the process of gasification of residues of biomass in some Brazilian agricultural cultures.

In relation to the carbonic gas produced in the process it is suggested that to quantify the carbon credits, the capture is made through its setting in the production of a fertilizer that had its approach value searched in the market.

To prove this possibility experiments in laboratorial scale had become, holding back the $\mathrm{CO}_{2}$ in the fertilizer ammonium bicarbonate. Termogravimetics analyses, spectra infra-red ray, x-rays diffratograms and $\mathrm{CHN}$ had been made and had confirmed that the product was the fertilizer ammonium bicarbonate. For the numerical values, it had been consulted in referring bibliographies, the Brazilian agricultural cultures with indices of production of known residues, establishing then a numerical database for the formation of the corresponding values.

The results of this wok allow to affirm that a great potentiality for the exploitation of the resultant gases of the gasification of the residues of biomass, mainly of the carbonic gas in the production of a fertilizer exists and, with the possibility of implementation of a Mechanism of Clean Development in the country.
\end{abstract}


1. LISTA DE ACRÔNIMOS ….......................................................... 10

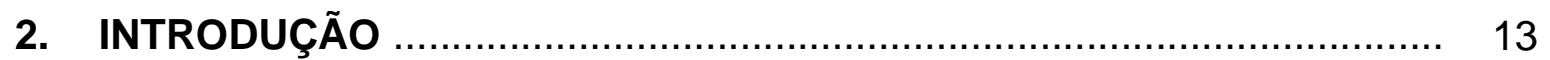

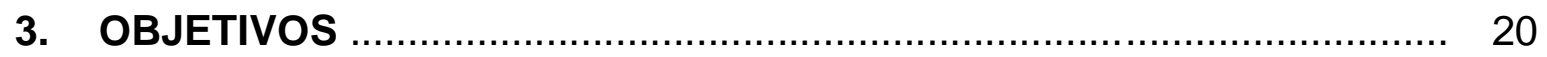

4. REVISÃO DA LITERATURA ..................................................... 21

4. 1. A "intensificação" do efeito estufa .............................................. 21

4. 2. O ciclo do carbono ........................................................................ 28

4. 3. A Convenção-Quadro das Nações Unidas sobre Mudanças do Clima-CQNUMC ................................................................ 31

4. 3. 1. O objetivo da CQNUMC ................................................. 32

4. 3. 2. A CQNUMC e as Conferências das Partes - COP's .......... $\quad 35$

4. 3. 3. Breve histórico das Conferência das Partes ....................... 44

4. 4. O Protocolo de Kyoto .............................................................. $\quad 50$

4. 4. 1. Mecanismos de flexibilização …………........................... 60

4. 4. 2. O Mecanismo de Desenvolvimento Limpo - MDL ............. 62

4. 4. 3. Artigos $M D L$ e sua aplicação no mercado ........................... 63

4. 4. 4. Locais de projetos MDL no mundo .................................. 66

4. 4. 5. Um exemplo de MDL no Brasil - Nova Gerar ...................... 67

4. 5. Estrutura Institucional de um MDL ............................................ 69

4. 5.1. Conselho Executivo do MDL .......................................... 69

4. 5. 2. Autoridade Nacional Designada (AND) ............................ 69

4. 5. 3. Autoridade Nacional Designada no Brasil .......................... 69

4. 5. 4. Entidades Operacionais Designadas (EOD's)...................... 71

4. 5. 5. Elegibilidade de um MDL ……......................................... 72

4. 5. 6. O ciclo do projeto de MDL ............................................... 73

4. 5. 7. Documento de Concepção do Projeto (DCP) …….............. 73

4. 5. 8. Linha de base ............................................................... 74

4. 5. 9. Cálculo de emissões da linha de base ............................... 75

4. 5. 10. Limites do projeto …………....................................... 76

4. 5. 11. Fuga ……............................................................... 76 
4. 5. 12. Adicionalidade ........................................................... 76

4. 5. 13. Monitoramento ............................................................... 78

4. 5. 14. Documentos e referências sobre impactos ambientais ....... 78

4. 5. 15. Comentários dos atores ............................................... 79

4. 5. 16. Informações sobre fontes adicionais de financiamento ....... 79

4. 5. 17. Validação e Aprovação ...................................................... 79

4. 5. 18. Registro pelo Conselho Executivo …………..................... 81

4. 5. 19. Verificação e Certificação .................................................... 81

4. 5. 20. Emissão das RCE's …................................................... 82

4. 6. Distribuição das atividades de projeto ............................................ 84

4. 6. 1. Projetos de MDL de grande escala ................................. 84

4. 6. 2. Projetos de MDL de pequena escala ................................ 85

4. 7. Panorama mundial e brasileiro de projetos MDL e RCE's ............... 89

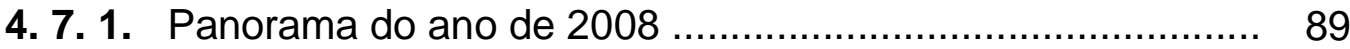

4. 7. 2. Panorama do ano de 2009 ............................................... 91

4. 8. Os custos de transação de um MDL ............................................. 94

4. 8. 1. Atratividade de um MDL e inventário de emissões ........... 96

4. 9. A crescente demanda de energia no mundo ................................ 98

4. 10. A crescente demanda de energia no Brasil ................................. 101

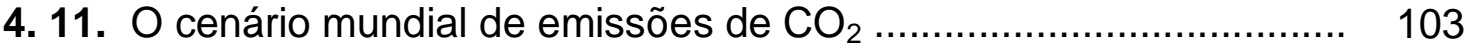

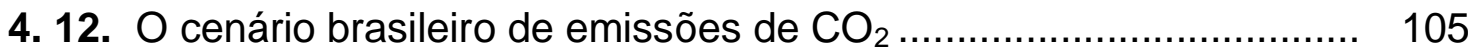

4. 13. A escala de Pacala e Socolow ...................................................... 111

4. 14. Captura, sequestro e armazenamento de gás carbônico - CAC .... 115

4. 14.1. Sequestro de carbono indireto ou terrestre - CAC indireto.. 116

4. 14. 2. Sequestro de carbono direto - CAC direto ....................... 117

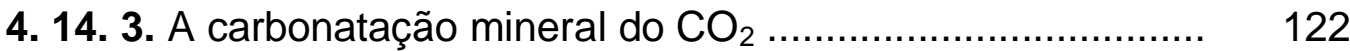

4. 14. 4. Os custos do CAC direto ................................................ 123

4. 15. Uma das energias renováveis - a biomassa ................................. 125

4. 15. 1. Conversão da biomassa ................................................ 128

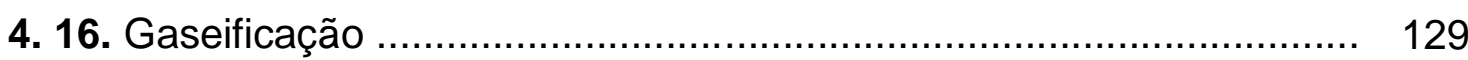

4. 16. 1. A tecnologia da gaseificação ........................................ 129

4. 16. 2. As etapas da gaseificação ............................................ 130

4. 16. 3. Principais tipos de gaseificadores .................................. 131 
4. 16. 4. Gaseificadores de leito fixo ......................................... 131

4. 16. 4. 1. Gaseificador contracorrente - "updraft" ........... 132

4. 16. 4. 2. Gaseificador co-corrente - "downdraft" ........... 135

4. 17. A gaseificação no mundo ...................................................... 137

4. 18. A gaseificação no Brasil .......................................................... 139

4. 18. 1. Organizações de pesquisa de gaseificação no Brasil...... 139

4. 19. Gás de síntese .................................................................. 142

4. 19. 1. Composição do gás de síntese .................................... 142

4. 20. Considerações iniciais sobre captura e fixação do $\mathrm{CO}_{2} \ldots \ldots \ldots \ldots \ldots \ldots . . . . .144$

4. 20. 1. Processo de captura do $\mathrm{CO}_{2}$ por absorção em hidróxido de amônio ....................................................................... 144

4. 20. 2. Processo de fixação de $\mathrm{CO}_{2}$ pela formação de compostos no solo

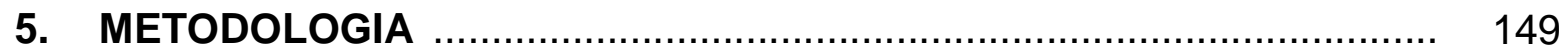

5. 1. Captura de $\mathrm{CO}_{2}$ e a produção de fertilizante ................................. 149

5. 2. Sistema gaseificação-sequestro de $\mathrm{CO}_{2}$ em escala laboratorial ....... 150

5. 2. 1. Procedimento ................................................................. 150

5. 3. Apuração das quantidades de resíduos de agrícolas brasileiros....... 152

6. RESULTADOS E DISCUSSÃO ….................................................... 161

6. 1. Síntese e caracterização do bicarbonato de amônio ......................... 161

6. 2. Determinação de $\mathrm{C}, \mathrm{H}, \mathrm{N}$........................................................... 163

6. 3. Análise térmica TG/DTA …...................................................... 164

6. 4. Espectros de absorção na região do infravermelho ........................ 165

6. 5. Espectros de difração de raios $X$ (método do pó) ........................... 167

6. 6. Estimativa da quantidade de $\mathrm{CO}_{2}$ e do fertilizante em função da produção de resíduos da agricultura brasileira ............................... 169

6. 7. Valoração do fertilizante produzido .............................................. 171

6. 8. Valoração das RCE's ................................................................... 172

7. CONCLUSÕES, PERSPECTIVAS E RECOMENDAÇÕES .................... 174

8. PROPOSTAS DE TRABALHOS FUTUROS .......................................... 178

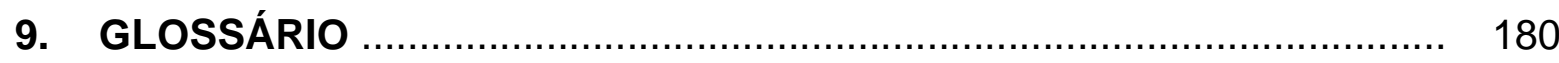

10 REFERÊNCIAS BIBLIOGRÁFICAS …................................................. 195 


\section{LISTA DE ACRÔNIMOS}

AAU (Assigned Amount Unit) - Unidade de Quantidade Atribuída.

AND Autoridade Nacional Designada

AOD Assistência Oficial ao Desenvolvimento

AOSIS Aliança de Pequenos Países Insulares.

BAU (Business-as-usual) - A expressão Business-as-usual Scenario equivale ao Cenário de Referência.

CDM (Clean Development Mechanism) - Mecanismo de Desenvolvimento Limpo.

CERs (Certified Emission Reductions) - Reduções Certificadas de Emissões.

CERT (Carbon Emission Reduction Trade) - É um modelo desenvolvido para o Banco Mundial, cujo objetivo é simular o emergente mercado de comercialização de redução de emissões de GEE. ${ }^{39}$

CIMGC Comissão Interministerial sobre Mudança Global do Clima.

CMMAD Comissão Mundial sobre Meio Ambiente e Desenvolvimento

COP (Conference of the Parties) - Conferência das Partes.

COP / MOP (Conference of the Parties serving as the Meeting of the Parties to the Kyoto Protocol) - Conferência das Partes na qualidade da Reunião das Partes do Protocolo de Kyoto.

CQNUMC Convenção-Quadro das Nações Unidas sobre Mudanças do Clima

CSI Corpo Subsidiário de Implementação - (SBI - Subsidiary Body for Implementation).

CSCCT Corpo Subsidiário para Conselho Científico e Técnico - (SBSTA Subsidiary Body for Scientific and Technical Advice).

CNUMAD Conferência das Nações Unidas sobre Meio Ambiente e Desenvolvimento.

DCP Documento de Concepção do Projeto

DDF Development Dividend Framework - Estrutura de desenvolvimento do dividendo. 
DNA (Designated National Authority) - Autoridade Nacional Designada.

DOE (Designated Operational Entity) - Entidade Operacional Designada.

EB (Executive Board) - Conselho Executivo.

EPE Empresa de Pesquisa Energética

EIA Estudo de Impacto Ambiental.

EOD Entidade Operacional Designada.

EPA (Environmental Protection Agency) - Agência de proteção ambiental sediada nos EUA.

ERU (Emission Reduction Unit) - Unidade de Redução de Emissões.

FGMA Fundo Global para o Meio Ambiente ou GEF - (Global Environment Facility).

GHG - GEE (Greenhouse Gases) - Gases de Efeito Estufa.

GWh Gigawatt-hora equivale a $10^{9}$ Wh ou 3,6 $\times 10^{12}$ joules.

GWP (Global Warming Potential) - Potencial de Aquecimento Global.

IBGE Instituto Brasileiro de Geografia e Estatística.

IEA (International Energy Agência) - Agência Internacional de Energia.

INC/FCCC Comitê Intergovernamental de Negociação para a Convenção-Quadro sobre Mudança do Clima.

IPCC (Intergovernmental Panel on Climate Change) Painel Intergovernamental sobre Mudança Climática.

JOULE - J É uma unidade de medida de energia e trabalho no sistema internacional de unidades e pode ser definida como, o trabalho necessário para exercer uma força de um newton por uma distância de um metro (N.m). Outra definição para joule é, o trabalho realizado para produzir um watt de energia durante um segundo (W.s).

JUSCANNZ Reúne as Partes que representam os países cujas emissões per capita são mais elevadas - Japão, EUA, Canadá, Austrália, Suíça, Noruega e Nova Zelândia. São parte desse grupo: Islândia, México e República da Coréia.

kWh Quilowatt-hora. É uma unidade de medida de energia. 1 kWh é a quantidade de energia dissipada por uma carga de 1.000 Watts durante uma hora. Equivalências: $1 \mathrm{kWh}=1000 \mathrm{Wh}$ ou $1 \mathrm{kWh}=3,6 \mathrm{x}$ $10^{6}$ joules ou $1 \mathrm{kWh}=3.412,14 \mathrm{Btu}$ ou $1 \mathrm{kWh}=859,845 \mathrm{Kcal}$ 
LULUCF Uso da Terra, Mudança de Uso da Terra e Florestas.

MWh Megawatt-hora equivale a 1.000 .000 Wh ou 3,6 $\times 10^{9}$ joules.

MCT Ministério de Ciência e Tecnologia.

MDL Mecanismo de Desenvolvimento Limpo.

MMA Ministério do Meio Ambiente.

MME Ministério de Minas e Energia.

ODA (Official Development Assistance) - Assistência Oficial ao Desenvolvimento.

OCDE Organização para a Cooperação e Desenvolvimento Econômico ou OECD - Organisation for Economic Co-Operationand Development.

OPEP Organização dos Países Exportadores de Petróleo.

PIMC Painel Intergovernamental em Mudanças Climáticas ou IPCC Intergovernmental Panel on Climate Change.

PDD (Project Design Document) - Documento de Concepção do Projeto.

RCEs Reduções Certificadas de Emissões.

RIMA Relatório de Impacto Ambiental

RMU (Removal Unit) Unidade de Remoção.

SAP (Structural Adjustment Programme) - Programa de ajuste estrutural.

TWh Terawatts-hora - equivale 10 elevado a $12 \mathrm{Wh}\left(10{ }^{12} \mathrm{Wh}\right)$

UNCTAD United Nations Conference on Trade and Development - Conferência das Nações Unidas sobre Comércio e Desenvolvimento.

UNEP (United Nations Environment Programme) - Programa das Nações Unidas para o Meio Ambiente.

UNFCCC (United Nations Framework Convention on Climate Change) Convenção - Quadro das Nações Unidas sobre Mudança do Clima.

UQA Unidade de Quantidade Atribuída.

URE Unidade de Redução de Emissões.

URM Unidade de Remoção.

Wh Watt-hora - equivale a 3.600 joules. Watt-hora é uma unidade de enegia e indica uma taxa de variação da potência com o tempo.

WMO (World Meteorological Organization) - Organização Meteorológica Mundial. 


\section{INTRODUÇÃO}

Já há algumas décadas, o aumento das emissões de gases poluentes apresenta-se como um problema global, apoiado por evidências científicas que constatam sua elevada concentração na atmosfera. É inegável que esse fato anda no mesmo compasso que o uso crescente das fontes de energia.

A Revolução Industrial, iniciada na Europa no século XVIII, provocou a exumação do carvão enterrado há milhões de anos, em proporções gigantescas, com o objetivo de girar as máquinas a vapor recém inventadas.

A extração de carvão mineral ainda é muito grande. Para se ter uma ideia do volume de carvão que necessita ser minerado no mundo, basta dizer que 52\% de toda a energia elétrica consumida nos Estados Unidos são provenientes da queima de carvão mineral ${ }^{1}$.

Proporções semelhantes ou ainda maiores são utilizadas na China, Rússia e Alemanha. Considerando o consumo atual e futuro, calcula-se que ainda exista carvão para mais 400 anos ${ }^{1,2,3}$.

Com o advento da produção em escala industrial dos automóveis, no início do século $X X$, iniciou-se a extração e o consumo em massa do petróleo e, de utilização mais recente, o gás natural na produção da energia elétrica, aquecimento doméstico e industrial e no uso de automóveis.

Nas projeções do caso de referência do IEO 2009, o consumo mundial de energia tem sido estimado para crescer $59 \%$ no horizonte de previsão de 30 anos, de 2000 a $2030^{4}$.

A maior parte do crescimento no uso mundial de energia é esperada nos países em desenvolvimento conforme projeção do caso de referência do IEO 2009, aumentando de 472 Quad (quadrilhão de BTU - 1 BTU = 1.055,05585 joules) em 2006 para 678 Quad em 2030, como se apresenta indicado na FIG. 1. Em virtude disso, a emissão de gases poluentes acompanhará essas tendências, crescendo em volume na atmosfera. 


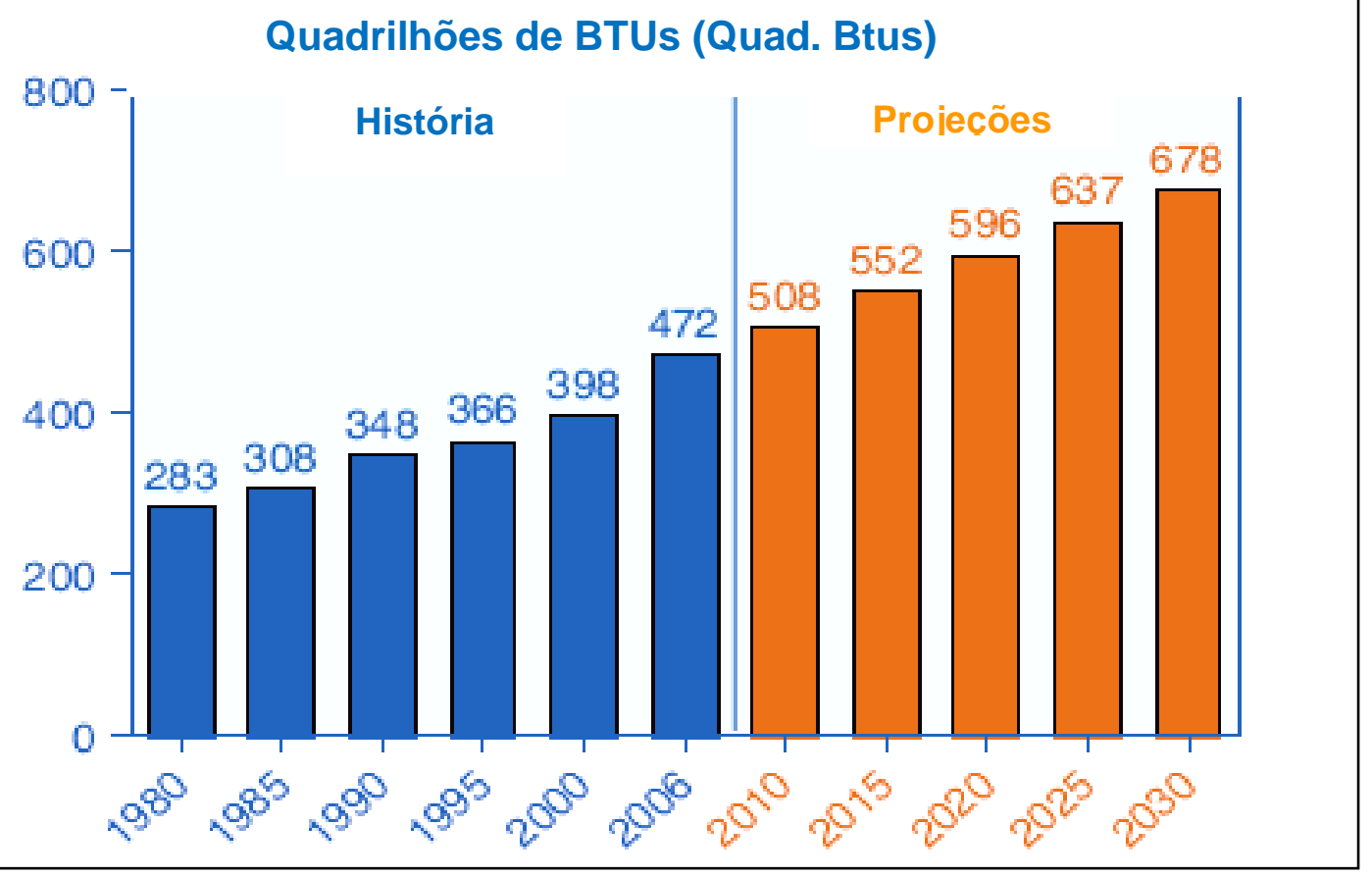

FIGURA 1 - Mercado mundial de consumo de energia, $1980-2030^{4}$.

Muitos acontecimentos influenciaram essa perspectiva, incluindo os altos preços persistentes do petróleo no mercado mundial. A explicação de que esse grande aumento projetado de emissões de gases de efeito estufa, destacando-se o gás carbônico, ocorra no mundo em desenvolvimento, é que nele estão as economias emergentes e, portanto, é onde haverá os maiores aumentos no consumo de energia também. Países em desenvolvimento sozinhos serão responsáveis por $81 \%$ do aumento projetado dessas emissões de dióxido de carbono entre 1990 e 2010 e $76 \%$ entre 1990 e $2020^{5}$.

A forte dependência contínua do carvão e outros combustíveis fósseis projetada para os países em desenvolvimento significa que, mesmo que o mundo industrializado exercitasse esforços para reduzir as emissões, estas aumentariam substancialmente no horizonte de previsão.

O processo da queima de combustíveis fósseis nos mais diferentes setores cria condições para a melhoria da qualidade de vida da humanidade, porém produz como resíduos, entre outros, muitas substâncias químicas condensadas e gases, todos muito poluidores. 
Estes gases conhecidos como gases de efeito estufa (GEE) são: gás carbônico $\left(\mathrm{CO}_{2}\right)$, o ozônio $\left(\mathrm{O}_{3}\right)$, óxido nitroso $\left(\mathrm{N}_{2} \mathrm{O}\right)$, metano $\left(\mathrm{CH}_{4}\right)$, hexafluoreto de enxofre $\left(\mathrm{SF}_{6}\right)$, acompanhado por suas famílias de gases, hidrofluorcarbonos (HFCs) e perfluorcarbonos (PFCs) 6,7,8,9, emitidos em razão das atividades antropogênicas, decorrentes principalmente da queima de combustíveis fósseis como carvão, gás natural, além do petróleo e seus derivados, em usinas termelétricas, indústrias, veículos em circulação e sistemas domésticos de aquecimento, e também de atividades agro-pastoris, lixões, aterros, do desflorestamento, da queima de resíduos agrícolas, entre outros ${ }^{10,11}$.

Essas atividades têm resultado na quase duplicação da concentração de gases de efeito estufa (GEE) e essa alteração poderá desencadear um aumento na temperatura média no planeta entre 1,4 e $5,8{ }^{\circ} \mathrm{C}$ nos próximos cem anos, em uma estimativa otimista ${ }^{8,12,13,14}$.

Para tratar do problema e suas possíveis consequências sobre a humanidade foi estabelecida em 1982, durante a Rio 92, a Convenção Quadro das Nações Unidas sobre Mudanças Climáticas (CQNUMC).

Em uma das reuniões após a Rio 92, realizada em Kyoto em 1997, buscouse estabelecer um acordo onde foram definidas metas de redução de emissões para todos os países envolvidos e seu comprometimento, além de critérios e diretrizes para a utilização dos mecanismos de mercado.

Este acordo, conhecido como Protocolo de Kyoto, estabeleceu que os países ditos industrializados devam reduzir suas emissões em 5,2\% abaixo dos níveis observados em 1990. Um dos resultados desse Protocolo foi a elaboração do Mecanismo de Desenvolvimento Limpo (MDL), cujo foco consiste em que, cada tonelada de $\mathrm{CO}_{2}$ deixada de ser emitida, ou retirada da atmosfera por um país em desenvolvimento, poderá ser negociada no mercado mundial através de Reduções Certificadas de Emissões (RCEs) ${ }^{15,16,17}$.

As RCEs, geradas em projetos MDL, em especial por projetos de sequestro de carbono, deixam claro que este mercado de carbono já é uma realidade, apesar de encontrar-se em estágio inicial de formação.

Quantitativamente, para se ter uma noção da evolução do quadro citado, os níveis de $\mathrm{CO}_{2}$ na atmosfera aumentaram 278 partes por milhão [ppm] em volume desde o período que antecede a Revolução Industrial, para cerca de 379 ppm em volume atualmente, ${ }^{18,19}$ como é mostrado na FIG 2. 
Embora o clima tenha sempre variado de modo natural, a velocidade e a intensidade no aumento da temperatura nesse período são incompatíveis com o tempo necessário à adaptação natural da biodiversidade e dos ecossistemas.

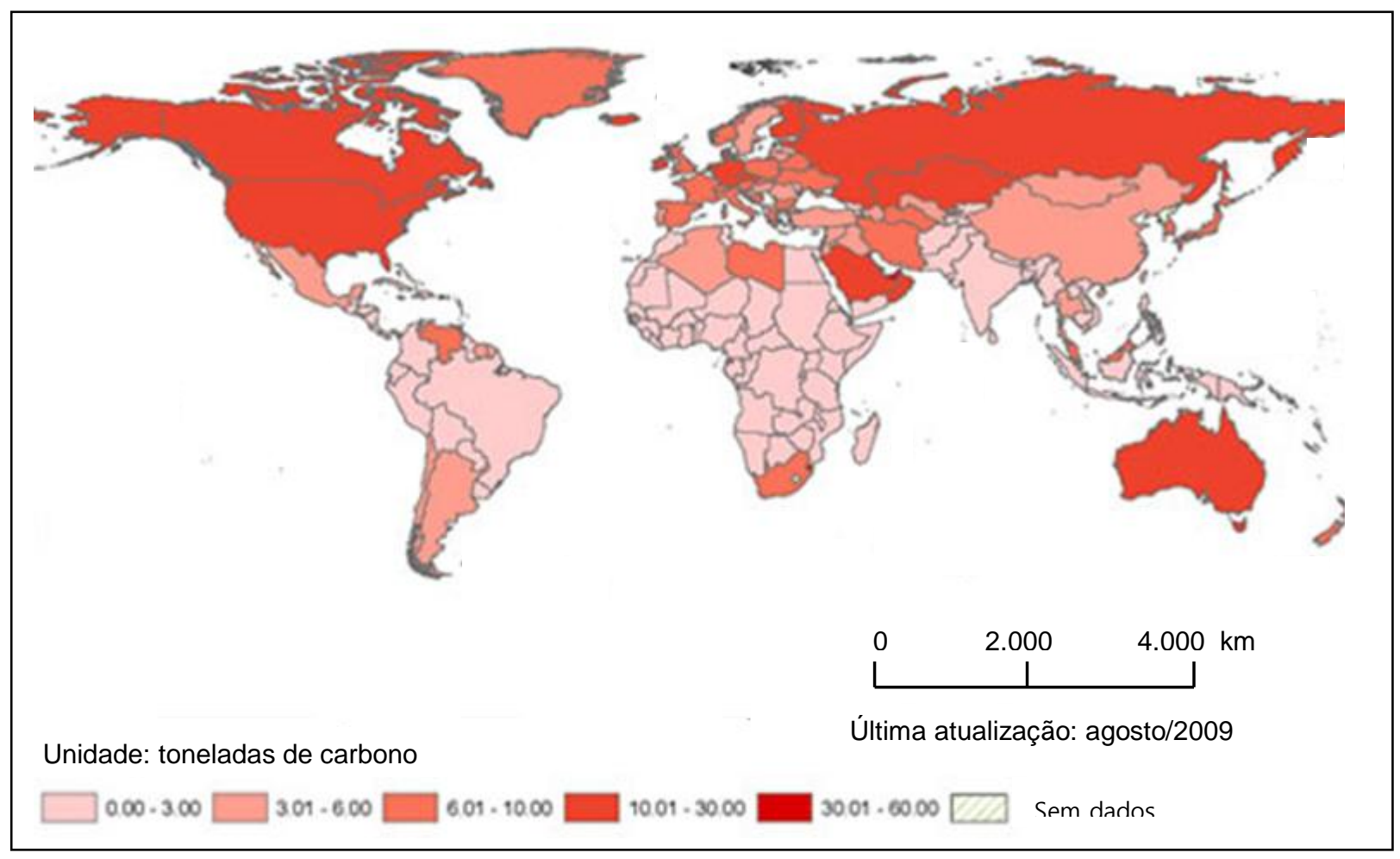

FIGURA 2 - Emissões per capita, de carbono, no mundo ${ }^{20}$.

Algumas alternativas para diminuir esse problema podem ser discutidas, como a otimização de processos, ganhos de eficiência energética e/ou substituição de combustíveis fósseis, sendo que esta opção ainda oferece resistência da maioria dos países pela dificuldade em encontrar substitutos viáveis tanto em grande escala quanto economicamente, ou uma redução no desflorestamento nas áreas tropicais, também de difícil implantação, visto que em grande parte dessas áreas existem as fronteiras agrícolas em expansão.

Uma das alternativas consideradas mais viáveis seria a não queima de resíduos agrícolas no campo de forma aleatória e descontrolada, o que contribui significativamente para a diminuição dos GEE na atmosfera ${ }^{21}$.

No cenário brasileiro, estima-se que, entre 1998 e 2000, o país tenha emitido, cerca de 285 milhões de toneladas de carbono, das quais 85 milhões são o resultado da queima de combustíveis fósseis, numa estimativa de $71 \%$ do uso 
de combustíveis líquidos, $15,6 \%$ da queima de carvão mineral e $4 \%$ de gás natural $22,23,24$.

Esse número é relativamente pequeno quando comparado às emissões provenientes da queima de combustíveis fósseis de outros países, já que a matriz energética brasileira é considerada relativamente limpa pelos padrões internacionais, uma vez que se baseia na energia hidrelétrica, que é renovável.

Cerca de dois terços das emissões do Brasil provém de atividades de uso da terra, tais como o desmatamento e as queimadas, o que, atualmente, representam $3 \%$ das emissões globais ${ }^{25}$.

Citando um exemplo, temos a cana-de-açúcar, responsável por cerca de $98 \%$ das emissões dos gases provenientes da queima de resíduos agrícolas no Brasil $^{26}$.

As queimadas, largamente empregadas, liberam na atmosfera uma grande quantidade de gases que provocam a elevação de suas concentrações auxiliando no fenômeno de intensificação do efeito estufa ${ }^{27,28}$.

Caminhando nesse sentido, o Estado de São Paulo elaborou a Lei Estadual no 11.241, de 19 de setembro de 2002 que prevê a redução gradativa da queima prévia de material orgânico nas áreas mecanizáveis, em terrenos acima de 150 hectares, com declividade igual ou inferior a 12\%, firmando o compromisso da eliminação total deste procedimento até o ano de 2021. E nas áreas onde não houver a possibilidade de mecanização, a queima será eliminada até $\mathrm{o}$ ano de $2031^{29}$.

Assim sendo, o aproveitamento da biomassa representa um potencial mitigador das emissões de gases e um atrativo maior para a implantação de Mecanismos de Desenvolvimento Limpo (MDL).

Com o manejo e a colheita dessa biomassa, sem as queimadas frequentes desse resíduo agrícola, o carbono eventualmente emitido, fica retido na palhada e no solo, permitindo que a agricultura nacional, ofereça novas oportunidades e atrativos para o investimento externo nos países em desenvolvimento e, ao mesmo tempo, contribuam para que os países ditos desenvolvidos ou industrializados atinjam suas metas de redução de emissão de GEE de forma custo-efetiva. 
Um dos processos mais conhecidos é o da gaseificação da biomassa, onde ocorre a formação de alguns dos GEE, dentre eles o $\mathrm{CO}_{2}$, cuja quantificação pode fornecer dados que trabalhados, demonstrarão as possibilidades de geração de créditos de carbono e os benefícios que trarão ao fluxo financeiro de projetos energéticos, visto que essa gaseificação também poderá gerar hidrogênio para o uso em células a combustível na geração de energia elétrica distribuída.

Concomitantemente, em relação aos benefícios ambientais, a quantificação e captura de carbono pode ser demonstrada mais especificamente com sua fixação na produção de fertilizantes nas camadas de solo e subsolo da terra, reduzindo a contaminação do ambiente em geral.

As conseqüências da implementação de um MDL enfocando esse ponto são positivas, já que trazem benefícios a todas as partes envolvidas no que tange:

i. ao aumento da eficiência energética global do próprio projeto;

ii. a um incremento no retorno financeiro do projeto através da venda de créditos de carbono;

iii. a um exemplo para o Brasil e o mundo da elegibilidade de políticas de desenvolvimento sustentável, pois a implantação de projetos que viabilizem a aplicação de um MDL foi idéia sugerida pelo Brasil, projetando de forma positiva nossa imagem para o exterior;

iv. ao fato de incrementar uma realidade já existente em muitas comunidades: a substituição das fontes convencionais de energia por fontes renováveis, diminuindo os impactos ambientais;

v. por último, mas não menos importante, apresenta-se neste trabalho um método que pode capturar e sequestrar o $\mathrm{CO}_{2}$ da gaseificação da biomassa. Este sequestro envolvendo o carbono pode beneficiar, ao mesmo tempo, a agricultura e a economia. A estratégia proposta utiliza uma aplicação para converter $\circ \mathrm{CO}_{2}$ em um fertilizante valioso, formando o bicarbonato de amônio $\left(\mathrm{NH}_{4} \mathrm{HCO}_{3}\right)$ favorecendo o sequestro de $\mathrm{CO}_{2}$ nas camadas de solo e subsolo da terra, reduzindo a contaminação por nitrato $\left(\mathrm{NO}_{3}{ }^{-}\right)$na água subterrânea e estimulando a fixação por fotossíntese do $\mathrm{CO}_{2}$ da atmosfera ${ }^{30,31,32}$. 
Todos esses enfoques demonstram que é possível diminuir as barreiras para a utilização e conversão da biomassa como fonte de energia, reforçando a sua contribuição para com o desenvolvimento sustentável, de acordo com os moldes do MDL e sua aprovação, fornecendo o aval e a credibilidade necessários que justificam um estudo do processo e uma análise dos passos que culminaram em sua implantação.

Projetos que buscam a obtenção de créditos de carbono, com base na formação de um fertilizante utilizando resíduos de biomassa, em sistemas de gaseificação para a geração de energia elétrica, ainda não aparecem no cenário nacional ou internacional.

Desta forma, mediante o desenvolvimento deste trabalho, o IPEN, por meio do Centro de Célula a Combustível e Hidrogênio $(\mathrm{CCCH})$ estaria fornecendo dados importantes aos programas instituídos pelo Ministério de Ciência e Tecnologia (MCT) 


\section{OBJETIVOS}

O objetivo primeiro desse trabalho é o de buscar quantificar o chamado "mercado de carbono", em especial, a participação do Brasil através do MDL e a sua formação e evolução até a obtenção das Reduções Certificadas de Emissão (RCEs). Nessa quantificação, o gás de síntese emitido na gaseificação dos resíduos de biomassa vegetal, dentro do contexto da utilização destes resíduos na geração de energia elétrica distribuída, será direcionado para a captura do $\mathrm{CO}_{2}$ através da produção de fertilizante.

Para tanto é necessário atingir os seguintes objetivos secundários:

i. Através do levantamento na literatura, em bibliografias das principais fontes conhecidas de resíduos de biomassa agrícola brasileira e, através de dados de gaseificação fornecidos na literatura, estimar e quantificar a produção de gás carbônico;

ii. Confirmar a captura do $\mathrm{CO}_{2}$, potencialmente emitido nessa gaseificação, na produção de um fertilizante, o bicarbonato de amônio.

iii. Estimar o valor deste fertilizante;

iv. Analisar a geração de "créditos de carbono", que são obtidos como consequência da captura do $\mathrm{CO}_{2}$, através do mercado de certificados de redução de emissão por meio da implantação de um MDL. 


\section{REVISÃO DA LITERATURA}

\section{1. A "Intensificação" do efeito estufa ${ }^{33,34,35,36,37,38,39}$}

Desde que o problema ambiental se apresentou com toda a força, na década de 1980, não pararam de crescer as preocupações e intensificaram-se estudos visando melhor caracterizar problemas específicos, na busca de possíveis soluções.

Houve conscientização da gravidade das agressões ao meio ambiente, dando lugar à mobilização da opinião pública, mormente nos países industrializados, tanto pelo desmatamento como pelo mau uso do solo e dos recursos hídricos. Nos países menos favorecidos, a questão ambiental passou a ser, dominantemente, um problema de poluição urbana nas grandes cidades.

Por toda parte fortaleceram-se administrativa e financeiramente grupos de ação com o objetivo de intervir no processo de deterioração generalizada.

Muitas dessas ações contribuíram para o encaminhamento de soluções. No entanto, o crescimento populacional, a ocupação de territórios finitos, a intensificação das atividades produtivas e a presença da pobreza continuaram a afetar negativa e inexoravelmente a natureza.

Um dos maiores e mais complexos processos se atém às emissões de gases poluentes decorrentes do uso da energia, de forma geral, seja de origem fóssil, seja de hidrelétricas e até de fontes domésticas. Agrava-se particularmente naqueles locais situados em áreas mais quentes, onde a flora e a fauna sofrem diretamente suas conseqüências, não deixando de ser relevante também no resto do planeta.

O efeito estufa é um fenômeno físico natural, que existindo independentemente das atividades humanas e dos sistemas econômicos, é responsável pela manutenção de uma temperatura superficial na Terra propícia à vida. Sem o efeito estufa a energia recebida do Sol que atravessa a atmosfera e é refletida pela superfície da Terra, retornaria ao espaço, integralmente. 
A primeira descrição do efeito estufa foi realizada no início do século XVIII pelo filósofo francês Jean-Baptiste Fourier que concebeu a Terra como uma estufa gigante que viabilizava a vida de plantas e animais ${ }^{18}$.

Entretanto, o primeiro a chamar a atenção sobre os possíveis impactos ambientais dos GEE foi o cientista sueco Svante Arrhenius, em 1896, ao determinar uma relação comparando a concentração atmosférica de gás carbônico com o efeito estufa ${ }^{40,41}$.

Em agosto de 1979 a expressão efeito estufa foi usada pela primeira vez pelo cientista e escritor Isaac Asimov ao escrever um artigo de caráter pioneiro comentando informações recentes sobre a atmosfera do planeta Vênus, muito quente, com seus $95 \%$ de $\mathrm{CO}_{2}{ }^{30}$.

Os GEE representam menos de um décimo da composição atmosférica, formada basicamente de oxigênio (21\%) e nitrogênio (78\%), mas desempenham um papel vital na manutenção da temperatura média no planeta, atualmente em aproximadamente $15 \stackrel{\circ}{\circ}$ positivos. Sem sua presença a temperatura da Terra seria cerca de 30 graus Celsius mais fria do que é hoje ${ }^{28}$.

Quanto maior a concentração de GEE maior também é a capacidade de retenção de calor na atmosfera e conseqüentemente maior a temperatura na superfície da Terra.

Apesar de o vapor de água ser abundante na atmosfera, o mais importante gás causador do efeito estufa é o gás carbônico, que vem sendo lançado de maneira natural pelos vulcões ao longo da história da Terra e agora tem suas concentrações elevadas pelas ações humanas.

Entretanto, é necessário distinguir o efeito estufa natural daquele acentuado pelas atividades humanas.

Para efeito deste trabalho, o uso da expressão "efeito estufa" estará sempre associado ao processo de aquecimento global provocado pelas emissões antropogênicas de GEE. Pelo fato dessa expressão já estar consagrada pelo uso, será assim usada neste trabalho. Entretanto o correto seria a "intensificação do efeito estufa".

O balanço de energia no sistema terra-atmosfera, como é mostrado na FIG. 3, apresenta, de forma esquemática, o efeito estufa natural, que pode ser acirrado com a emissão desenfreada de GEE. 


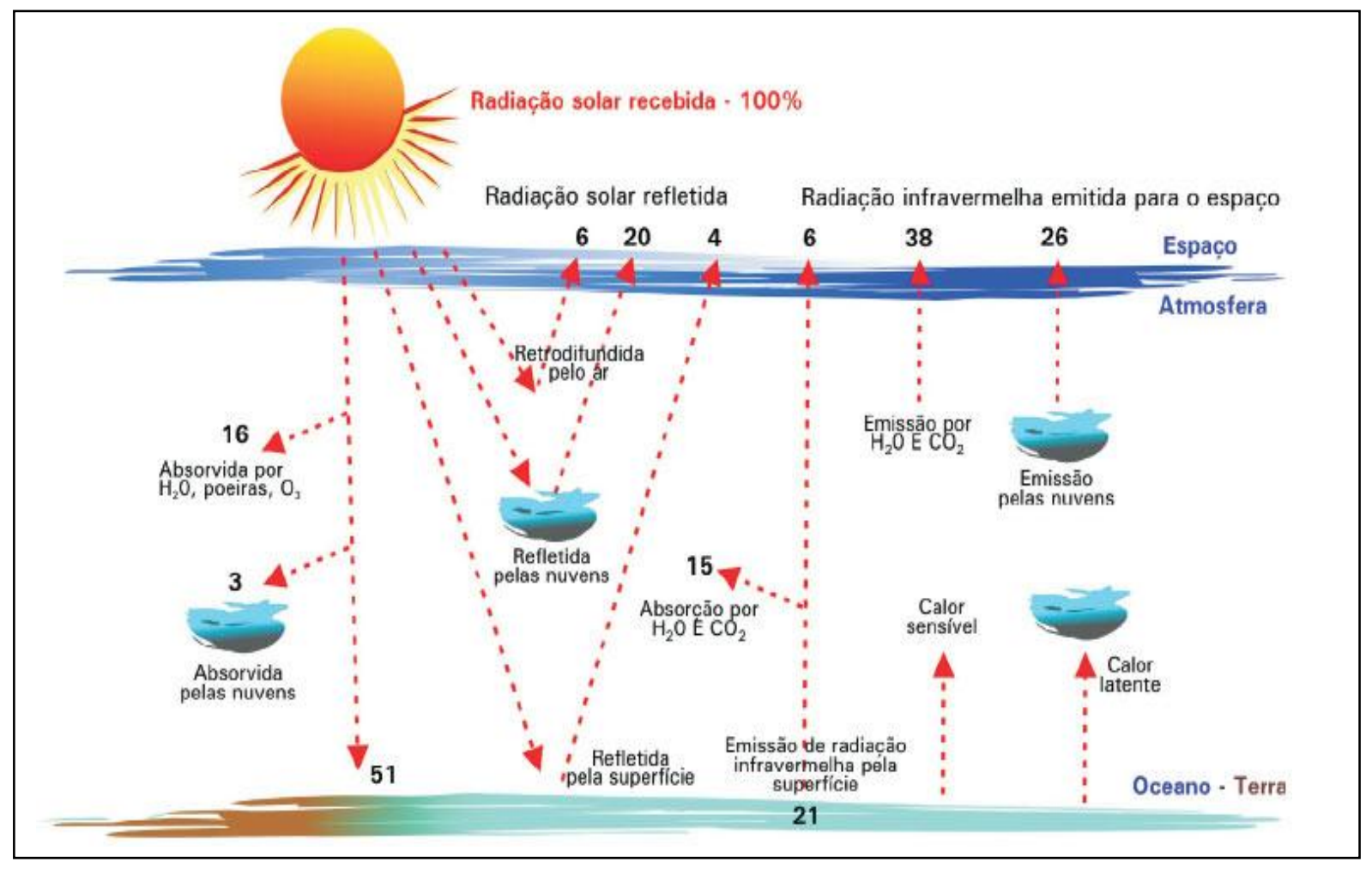

FIGURA 3 - Diagrama do efeito estufa ${ }^{42}$.

O mais significativo dos GEE é o dióxido de carbono. Segundo relatório emitido pelo SAP-WGIII (2003), 75\% do total de emissões de $\mathrm{CO}_{2}$ é proveniente do uso intensivo dos combustíveis fósseis (carvão mineral, petróleo e gás natural) e praticamente todo o resto de desmatamento e queimadas ${ }^{3}$.

Em 1958, o oceanógrafo Charles David Keeling, iniciou uma série de experiências na estação de Mauna Loa, localizada no Havaí, revelando com bastante precisão a concentração de $\mathrm{CO}_{2}$ na atmosfera, conforme é mostrado na FIG. 4. Em 1959, primeiro ano em que o nível de $\mathrm{CO}_{2}$ foi registrado, a média era de 316 partes por milhão (ppm) e no ano seguinte, já chegara a 317 ppm.

Em 1970, o nível observado marcava 325 ppm e, 20 anos depois, já estava em 354 ppm. De forma alarmante, no verão de 2005, o nível de $\mathrm{CO}_{2}$ marcou uma média de 378 ppm e, atualmente, 2009, encontra-se em uma concentração aproximada de 385 ppm.

Seguindo esses dados, esse gás poderá alcançar, em 2100, no mínimo, mais de 500 ppm - quase o dobro dos índices pré-industriais e, alarmantemente podendo chegar ao patamar incrível, de quase 1000 ppm ${ }^{43,44,45}$. 


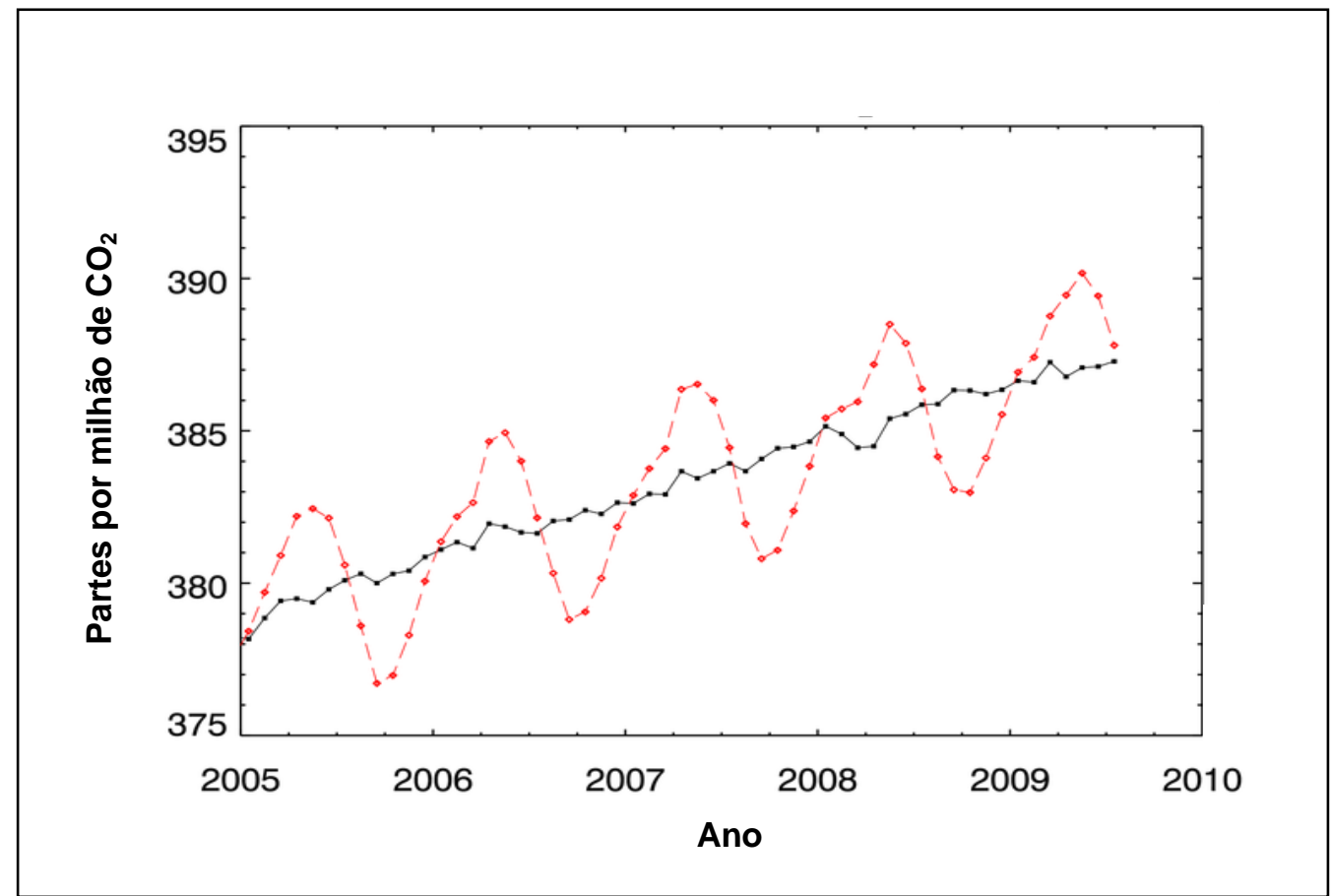

FIGURA 4 - Curva de Keeling indicando as concentrações de $\mathrm{CO}_{2}$ atmosférico medidas em Mauna Loa, Havai, em outubro de 2009 44,46.

As emissões de gás carbônico no Brasil, provenientes dos diversos tipos de atividades que utilizam combustíveis, cresceram vertiginosamente desde 1990 e a projeção para os próximos anos não mostra tendências de diminuição, como pode ser observado na FIG. $5^{24}$.

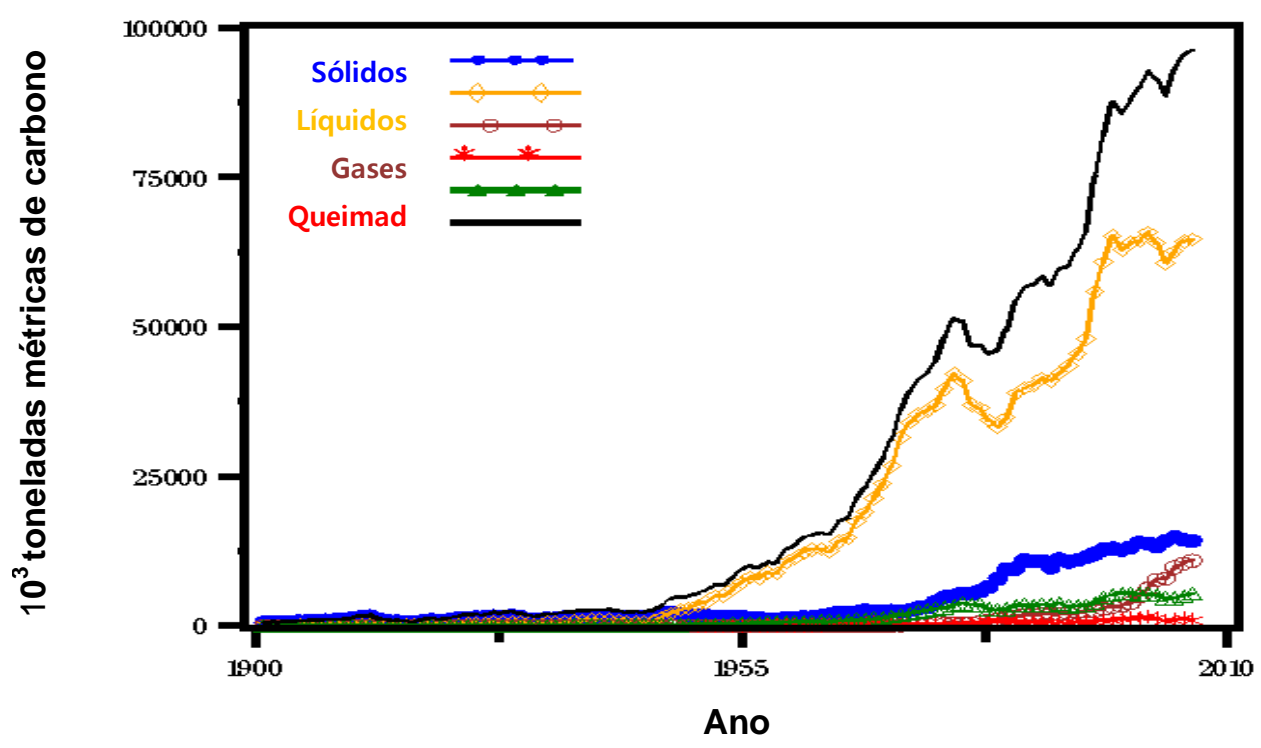

FIGURA 5 - Emissões de $\mathrm{CO}_{2}$ no Brasil. 
É preciso salientar que os países desenvolvidos têm recebido a responsabilidade de serem os que mais contribuíram e ainda contribuem para 0 aumento da concentração de GEE, como é mostrado na FIG. 6, indicativa da classificação dos vinte maiores responsáveis de emissões de $\mathrm{CO}_{2}$. Nessa classificação, o Brasil encontrava-se na $18^{\text {a }}$ posição em $2007^{24}$. Incluindo-se, porém, as queimadas e desmatamentos, muito usados no país, essa classificação muda, colocando-o entre os seis primeiros emissores de GEE ${ }^{23,47}$.

Estima-se que no país existam de 10.000 a 25.000 toneladas de carbono para cada quilômetro quadrado de florestas e resíduos, sendo que, com as queimadas, cerca de 2/3 deste carbono será convertido em $\mathrm{CO}_{2}{ }^{49}$.

Diante disso, o país se vê pressionado a assumir compromissos voluntários de redução das emissões de GEE. Os impactos de tais compromissos sobre a economia brasileira ainda são controversos, podendo ser significativos em alguns setores $^{50}$.

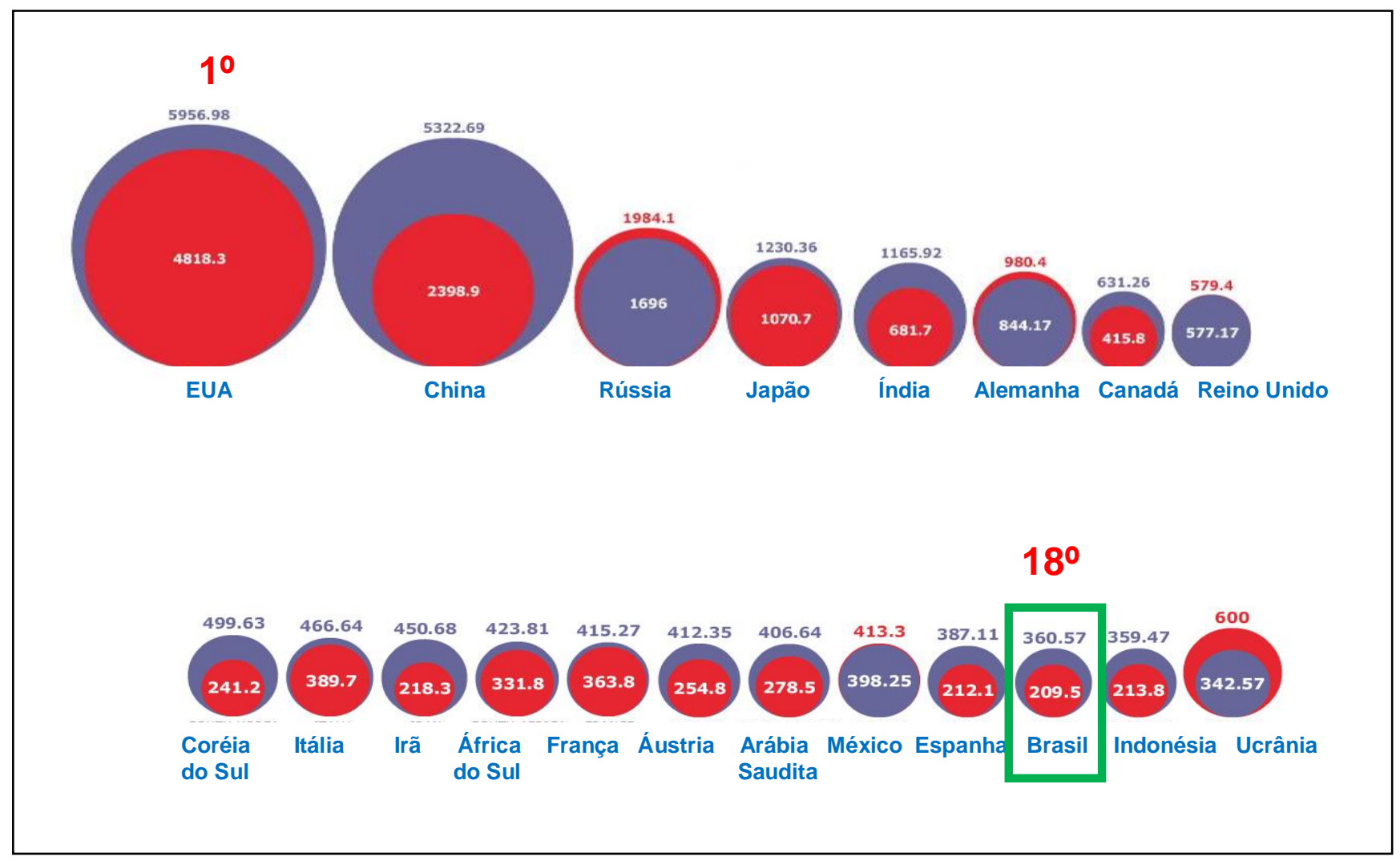

FIGURA 6 - Os vinte países mais poluidores do mundo. Os círculos vermelhos mostram suas emissões em 1990 e os azuis, suas emissões em 2007. As emissões estão computadas em milhões de toneladas de $\mathrm{CO}_{2}{ }^{24}$. 
Se os níveis dos gases estufa proverem um isolamento durante um período longo de tempo, a Terra eventualmente se tornará muito quente para a manutenção da vida e esse aquecimento global poderá ser catastrófico.

À medida que o gelo das calotas polares derrete, por exemplo, o nível do mar se eleva, inundando terras mais baixas e, talvez, submergindo países inteiros no Oceano Pacífico. Países como Bangladesh e Egito, por exemplo, podem perder até um décimo de seus territórios, o que obrigaria o deslocamento de dezesseis milhões de pessoas ${ }^{36,144}$.

O derretimento de geleiras das montanhas poderá provocar avalanches, erosão dos solos e mudanças dramáticas no fluxo dos rios, aumentando o risco de enchentes ${ }^{36}$.

Alterações bruscas na composição da atmosfera desencadearão mudanças dramáticas no clima, resultando em grandes variações na temperatura e no ritmo de chuvas. Furacões, tormentas e enchentes, de um lado, e secas graves, de outro, poderão se tornar mais frequentes ${ }^{52}$.

Especialistas, cientistas e estudiosos acreditam que os desertos poderão crescer e que as condições de tempo nas regiões semi-áridas, como no Nordeste do Brasil, serão ainda mais críticas.

Tudo isso poderá repercutir negativamente na produção de alimentos, já que diversas áreas cultiváveis serão afetadas. As alterações climáticas incomuns podem reduzir severamente populações de seres vivos ou levar à extinção de muitas espécies incapazes de se adaptar às novas condições ambientais, que afetam o equilíbrio de diversos ecossistemas.

Segundo o IPCC, os impactos econômicos sociais e ambientais decorrentes do aquecimento global afetarão todos os países, porém serão sentidos de maneira diferenciada. Embora não se conte, ainda, com um modelo que permita avaliar com exatidão a extensão e intensidade do efeito estufa, o risco de protelar medidas preventivas é muito grande ${ }^{34}$.

Sendo assim, vemos a humanidade caminhando em uma direção onde não há mais um futuro a descobrir e sim um já descoberto e conhecido em função dos impactos que estão ocorrendo diariamente e os que ainda estão por vir através das ações antrópicas

$\mathrm{Na}$ TAB.1 apresenta-se um resumo de algumas previsões desses impactos em diversas regiões do mundo. 
TABELA 1 - Possíveis impactos decorrentes do aquecimento global ${ }^{34}$.

\section{Região}

1. África

\section{Prováveis impactos}

- Aumento dos vetores de diversas doenças.

- Diminuição da produção agrícola.

- Extinção de muitas espécies da fauna e flora.

- Diminuição da disponibilidade de água na região do Mediterrâneo e em países do sul.

- Aumento da desertificação.

2. Ásia

- Diminuição da produção agrícola.

- Diminuição da disponibilidade de água nas regiões do árido e semi-árido.

- Aumento do nível do mar que deverá deslocar dezenas de milhões de pessoas.
3. Austrália e Nova Zelândia

4. Europa
- Diminuição da disponibilidade de água.

- Extinção de espécies da fauna e flora.

- Desaparecimento das geleiras dos Alpes.

- Aumento da produção agrícola em algumas regiões.

- Impactos no turismo.

5. América Latina

- Diminuição da produção agrícola.

- Aumento dos vetores de diversas doenças.

- Extinção de espécies da fauna e flora.

6. América do Norte

- Aumento da produção agrícola em algumas regiões.

- Aumento dos vetores de diversas doenças.

7. Regiões Polares

- Diminuição da calota polar.

- Extinção de espécies da fauna e flora.

8. Pequenas Ilhas
- Aumento do nível do mar que deverá deslocar dezenas de milhões de pessoas.

- Diminuição da disponibilidade de água.

- Diminuição da atividade pesqueira.

- Diminuição no turismo. 


\section{2. O ciclo do Carbono}

O elemento carbono caracteriza-se como um tema de ampla discussão e importância. Suas características físicas e químicas são o que possibilitam tamanha diversidade dos compostos orgânicos e até onde se sabe a vida na Terra não seria possível com a sua ausência, porém o seu excesso em forma de dióxido de carbono ameaça esta vida por ele possibilitada.

Presente desde os primórdios da vida da Terra é encontrado em abundância no Sol, nas estrelas, nos cometas e na atmosfera da maioria dos planetas. $\mathrm{Na}$ forma de diamantes microscópicos, foi encontrado em alguns meteoritos. O carbono é um elemento único, pela enorme quantidade de compostos que pode formar ${ }^{54}$.

Combinando-se com oxigênio, hidrogênio, nitrogênio e outros elementos, forma uma vasta coleção de compostos (cerca de 10 milhões deles), muitos dos quais essenciais para a vida e os processos orgânicos ${ }^{53,54}$.

Além disso, o carbono está presente em muitas das fontes de energia que o homem utiliza, tais como carvão, biomassa, petróleo e gás natural.

A reação do carbono com outro elemento presente no ambiente, o oxigênio, leva à formação de monóxido de carbono ou de gás carbônico, como indicado nas equações a seguir: ${ }^{53,54}$

i. se a quantidade de $\mathrm{O}_{2}$ estiver abaixo da relação estequiométrica forma-se monóxido de carbono:

$$
2 \mathrm{C}+\mathrm{O}_{2} \longrightarrow 2 \mathrm{CO}
$$

ii. se a quantidade de $\mathrm{O}_{2}$ estiver em excesso, forma-se dióxido de carbono

$$
\mathrm{C}+\mathrm{O}_{2} \longrightarrow \mathrm{CO}_{2}
$$

O ciclo do carbono é o processo pelo qual o dióxido de carbono é recolhido da atmosfera, processado na litosfera pelas plantas, florestas e afins e na hidrosfera (oceanos) pelas algas, plâncton e outros organismos que possuam a capacidade de realização de fotossíntese, fenômeno esse, que por fim, consegue converter o dióxido de carbono em alimento para os seres fotossintetizantes e liberar oxigênio e vapor de água na atmosfera ${ }^{31,51}$. 
Sabe-se que em condições adequadas, a fotossíntese ocorre na litosfera e que os oceanos conseguem absorver de forma bem mais eficiente o dióxido de carbono, revelando-se uma fonte positiva na diminuição do efeito estufa.

Além disso, o solo consegue armazenar cerca de três vezes mais carbono que a atmosfera em virtude da fixação pelos vegetais e dos microorganismos presentes nesses ambientes ${ }^{23}$.

Pelo exposto, percebe-se que o solo é um importante sumidouro e fonte de retenção de $\mathrm{CO}_{2}$ e o manejo inadequado de grandes regiões de terra tem um impacto crítico na atmosfera ${ }^{55}$.

Citando um exemplo de cultivo inadequado, ao fazer-se uma monocultura por cerca de 10 anos, pode-se liberar mais de $50 \%$ do carbono que estaria estocado no solo para a atmosfera em forma de dióxido de carbono ${ }^{23,49}$.

Tal processo de estocagem de carbono no solo, a partir de materiais em decomposição, além de reter o elemento, também é o formador de combustíveis fósseis como o gás natural e o petróleo, processo que ocorre desde os primórdios da formação da Terra ${ }^{51,56}$.

Percebe-se, então, que a intervenção humana como a poluição e o desmatamento tendem a favorecer a liberação de carbono no ambiente.

Elencado a isso se tem um dos maiores problemas enfrentados pela humanidade nas últimas décadas: sua crescente dependência de fontes energéticas.

Estas por sua vez, acabam trazendo consigo um dos principais dilemas para o ambiente: de que formas se poderia desvincular as emissões de gás carbônico que essas fontes emitem com o desenvolvimento humano?

Como se observa na FIG. 7, que representa o ciclo de carbono e as interligações entre as diferentes fontes deste elemento no planeta, percebe-se a dificuldade que qualquer tentativa de alteração no modelo atual de consumo energético, baseado em fontes fósseis e profundamente enraizado no processo produtivo, acabaria levando a enormes implicações econômicas ${ }^{51,57}$. 


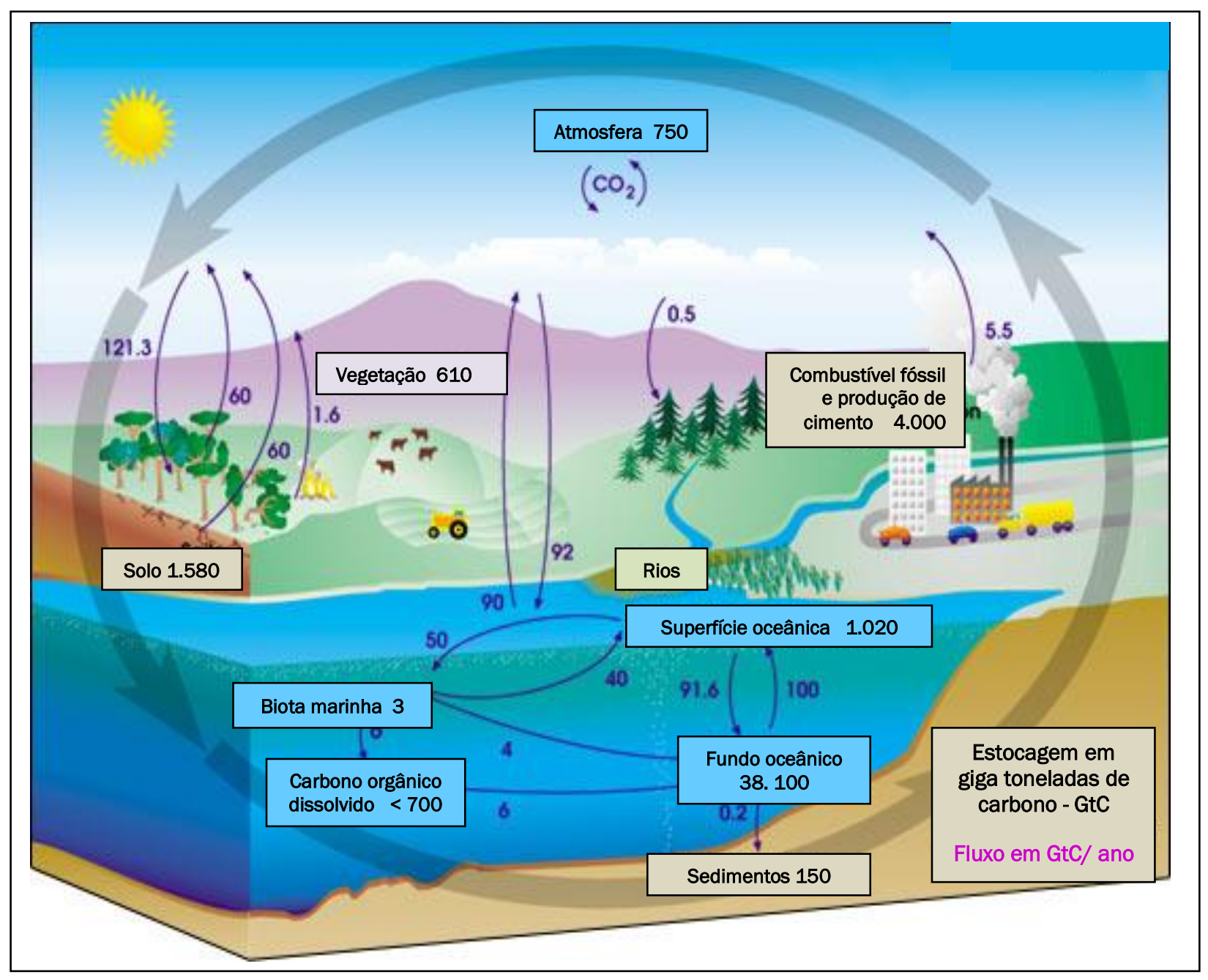

FIGURA 7 - O ciclo do carbono. $\mathrm{Na}$ figura, as quantidades de carbono armazenado (GtC) encontram-se indicadas pelas setas com cores em azul e os fluxos anuais de carbono (GtC/ano) estão indicados pelas setas com cores em roxo ${ }^{57}$.

Entretanto, as evidências científicas a respeito dos vínculos do efeito estufa com as mudanças climáticas, a conseqüente necessidade de redução das emissões de $\mathrm{CO}_{2} \mathrm{e}$, ainda, as crescentes demandas da sociedade por qualidade ambiental e por maior sustentabilidade do processo produtivo fazem com que 0 problema comece a ser enfrentado. 


\section{3. Convenção-Quadro das Nações Unidas sobre Mudanças do Clima}

Com base na recomendação apresentada no primeiro relatório de avaliação do IPCC em 1990, a Assembléia Geral das Nações Unidas deu início formal ao processo de negociação para o estabelecimento de uma convenção sobre as mudanças do clima $58,59,60$.

Em 1992, o Comitê Intergovernamental de Negociação para a ConvençãoQuadro sobre Mudança do Clima (INC/FCCC), que mais tarde culminou na criação da Convenção-Quadro das Nações Unidas sobre Mudança do Clima (CQNUMC) elaborou a sua redação, que foi aberta às assinaturas de todos os chefes presentes durante a Cúpula da Terra no Rio de Janeiro (Eco-92).

$\mathrm{Na}$ ocasião, os participantes assinaram a convenção e 168 confirmaram sua posição quanto ao respeito à convenção sobre a biodiversidade ${ }^{25,61}$.

Em 21 de março de 1994, a convenção entrou em vigor e, atualmente conta com 194 "partes" ou países signatários, que reconheceram a mudança do clima como uma preocupação comum da humanidade, provocada pela emissão antropogênica de GEE, comprometendo-se a elaborar estratégias globais para proteção do sistema climático para as gerações presentes e futuras ${ }^{62,63}$.

Fatos cientificamente comprovados foram apresentados na Convenção para demonstrar a gravidade do problema que a humanidade terá que enfrentar e reforçando a necessidade de se tomarem medidas imediatas.

Entre eles citam-se: ${ }^{64,65,66}$

i. a década de 1990 foi apontada como a mais quente da segunda metade do século XX;

ii. cientistas do IPCC, com base em diversos cenários, estimam que devido às atividades humanas, em 2100 as concentrações de GEE podem chegar a valores entre 540 e 970 partes por milhão;

iii. como consequência, as temperaturas médias mundiais podem aumentar entre $0,8{ }^{\circ} \mathrm{C}$ e $2,6{ }^{\circ} \mathrm{C}$ no período de 1990 a 2050, podendo atingir no ano de 2100 valores entre $1,4 \stackrel{\circ}{\circ}$ e e $5,8{ }^{\circ} \mathrm{C}{ }^{34,67,68}$. Este aumento previsto representa a maior variação de temperatura média global desde a última era glacial, que foi de cerca de $6{ }^{\circ} \mathrm{C}^{36,69}$. 
Os países participantes da CQNUMC, de um modo geral, dividem-se em alguns grupos que compartilham da mesma opinião para tomar decisões e de certa forma obter maior representatividade no que tange a este tema, estando resumidamente listados abaixo: ${ }^{70,71}$

i. Grupo dos 77 e China - representa os interesses de 132 países em desenvolvimento e busca harmonizar as posições de negociação entre seus membros (o Brasil faz parte deste grupo);

ii. $\underline{\text { AOSIS }}$ - Aliança de Pequenos Países Insulares: 43 países vulneráveis à elevação do mar;

iii. União Européia - 15 países da Comunidade Européia que votam em bloco;

iv. JUSCANNZ - reúne as Partes que representam os países cujas emissões per capita são mais elevadas: Japão, EUA, Suíça, Canadá, Austrália, Noruega e Nova Zelândia. São convidados desse grupo Islândia, México e República da Coréia;

v. Umbrella Group (extinto) - incluía países do JUSCANNZ, EUA, mais Islândia, Rússia e Ucrânia;

vi. OPEP - Organização dos Países Exportadores de Petróleo;

vii. Grupo dos países árabes;

viii. Observadores - organizações internacionais como UNEP, UNCTAD, WMO, OCDE, IEA e cerca de 400 ONGs assistem às COPs, sem direito a voto e desde que credenciadas.

\subsubsection{O objetivo da CQNUMC}

Ao adotar o princípio da responsabilidade comum, porém diferenciada, os países signatários da CQNUMC reconhecem que a maior parcela das emissões globais, históricas e atuais, de gases de efeito estufa é originária dos países desenvolvidos. Em decorrência, esses países devem tomar a iniciativa no combate à mudança do clima e seus efeitos ${ }^{64}$.

No documento oficial da CQNUMC, consta o objetivo da convenção: ${ }^{19,70}$

"O objetivo final da Convenção e de quaisquer instrumentos jurídicos com ela relacionados (...) é o de alcançar, em conformidade com as disposições 
pertinentes desta Convenção, a estabilização das concentrações de gases de efeito estufa (...) que impeça uma interferência antrópica perigosa no sistema climático. (...) deverá ser alcançado num prazo suficiente que permita aos ecossistemas adaptarem-se (...) à mudança do clima, que assegure que a produção de alimentos não seja ameaçada e que permita ao desenvolvimento econômico prosseguir de maneira sustentável."

De outra forma, os países em desenvolvimento, mesmo possuindo níveis de emissão per capita relativamente altos, têm o direito de aumentar sua parcela de emissões, satisfazendo suas necessidades sociais e de desenvolvimento. Deste modo, os signatários são divididos em dois grupos principais, o primeiro composto pelos países industrializados, listados no Anexo I da CQNUMC e conhecidos como Partes/Países Anexo I, e o segundo composto por todos os demais países, conhecidos como Partes/Países Não Anexo I. A Convenção não define a forma de atingir o objetivo para cada Parte/País, mas estabelece mecanismos de negociação e adotou os seguintes princípios: ${ }^{33,62,72}$

i. as Partes devem proteger o sistema climático em benefício das gerações presentes e futuras da humanidade com base na eqüidade e em conformidade com suas responsabilidades comuns, mas diferenciadas e de acordo com suas respectivas capacidades;

ii. devem ser levadas em plena consideração as necessidades específicas e circunstâncias especiais das Partes/países em desenvolvimento;

iii. as Partes devem adotar medidas de precaução para prever, evitar ou minimizar as causas da mudança do clima e mitigar seus efeitos negativos;

iv. as Partes têm o direito ao desenvolvimento sustentável e devem promovê-lo;

v. as Partes devem cooperar para promover um sistema econômico internacional favorável e aberto condizente ao crescimento e ao desenvolvimento econômico sustentáveis de todas as Partes, em especial das Partes/países em desenvolvimento, possibilitando-lhes, assim, enfrentar melhor os problemas da mudança do clima. 
Para a implementação da CQNUMC foram criados alguns órgãos que seriam responsáveis por fazer com que seus objetivos fossem atingidos: ${ }^{65,73}$

i. $\underline{C O P / M O P}$ - Conferência das Partes - O corpo supremo da Convenção. Inclui as nações que ratificaram a UNFCCC e mais um grupo de observadores convidados (organizações internacionais como UNEP, UNCTAD, WMO, OCDE, IEA e ONGs credenciadas). O Papel da COP é promover e revisar a implementação da UNFCCC, revisar compromissos existentes periodicamente levando em conta os objetivos da convenção, divulgar novas pesquisas científicas e verificar a efetividade dos programas de mudanças climáticas nacionais.

i. $\quad$ CSI - Corpo Subsidiário de Implementação (SBI - Subsidiary Body for Implementation) - O CSI é o corpo permanente estabelecido para ajudar os participantes da CQNUMC a avaliar e implementar a Convenção.

ii. FGMA - Fundo Global para o Meio Ambiente (GEF - Global Environment Facility) - O GEF foi estabelecido em 1991 e serve como mecanismo financiador da CQNUMC, fornecendo assim as concessões e empréstimos aos países elegíveis, para auxílio no atendimento aos objetivos da Convenção.

iii. CSCCT - Corpo Subsidiário para Conselho Científico e Técnico (SBSTA - Subsidiary Body for Scientific and Technical Advice): Foi estabelecido para proporcionar para a COP e seus corpos subsidiários, informação e conselho em assuntos científicos e tecnológicos como provenientes do IPCC relacionados a CQNUMC.

iv. $\underline{P I M C}$ - Painel Intergovernamental em Mudanças Climáticas (IPCC): O corpo responsável pelas avaliações técnicas e científicas, no apoio a CQNUMC. Consiste em milhares de cientistas do mundo inteiro, e entrega anualmente relatórios de avaliação referentes às mudanças climáticas e seus possíveis impactos globais. 


\section{3. 2. $A C Q N U M C$ e as Conferências das Partes - COP's}

A Conferência das Partes (COP) é o órgão supremo da CQNUMC, formada pelos Países que a ratificaram e convocada anualmente para revisão e adequação dos compromissos acordados. A Convenção Quadro das Nações Unidas sobre Mudanças Climáticas estabeleceu-se em 1992, durante a Rio 92 e trata da questão da intensificação do efeito estufa e suas possíveis conseqüências sobre a humanidade ${ }^{64}$. A CQNUMC entrou em vigor em 21/03/1994 e desde então as partes envolvidas reúnem-se e discutem o assunto, para encontrar soluções aos problemas apresentados nos encontros entre os países membros, denominados Conferência das Partes ou COP's ${ }^{34}$. Na TAB. 2 encontram-se listadas as reuniões realizadas até o ano de 2008.

TABELA 2 - Lista das Conferências das Partes realizadas até $2008^{74}$.

\begin{tabular}{cccc}
\hline COP & Ano & Datas & Local \\
\hline COP 1 & 1995 & 28 de março a 7 de abril & Berlim \\
COP 2 & 1996 & 8 a 19 de julho & Genebra \\
COP 3 & 1997 & 1 a 12 de dezembro & Kyoto \\
COP 4 & 1998 & 2 a 13 de novembro & Buenos Aires \\
COP 5 & 1999 & 25 de outubro a 5 de novembro & Bonn \\
COP 6 & 2000 & 13 a 24 de novembro & Haia \\
COP 7 & 2001 & 29 de outubro a 09 de novembro & Marrakech \\
COP 8 & 2002 & 23 de outubro a 01 de novembro & Nova Delhi \\
COP 9 & 2003 & 1 a 12 de dezembro & Milão \\
COP 10 & 2004 & 6 a 17 de dezembro & Buenos Aires \\
COP 11 & 2005 & 3 a 10 de dezembro & Montreal \\
COP 12 & 2006 & 6 a 17 de novembro & Nairóbi \\
COP 13 & 2007 & 3 a 14 de dezembro & Pali \\
COP 14 & 2008 & 12 de dezembro & Ponânia) \\
\hline
\end{tabular}


As ações propostas nessas COP's deram ênfase ao uso de mecanismos de mercado, visando à redução dos custos de mitigação do efeito estufa, e o estabelecimento do desenvolvimento sustentável em países subdesenvolvidos ${ }^{62}$.

Nela, os países participantes foram classificados como Partes, apresentam-se estando listados na TAB. 3.

TABELA 3 - Países/Organizações que assinaram a CQNUMC ${ }^{75}$.

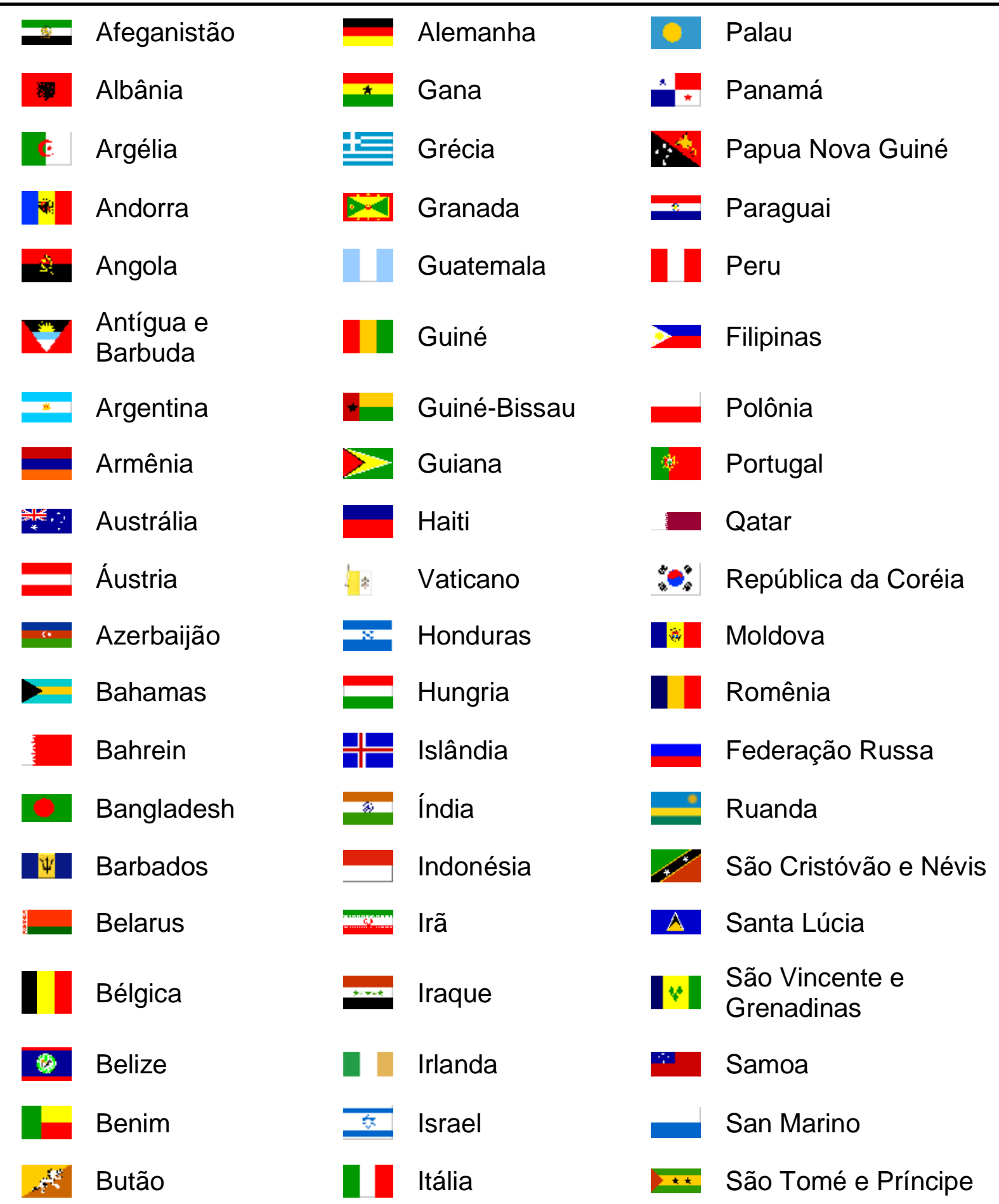




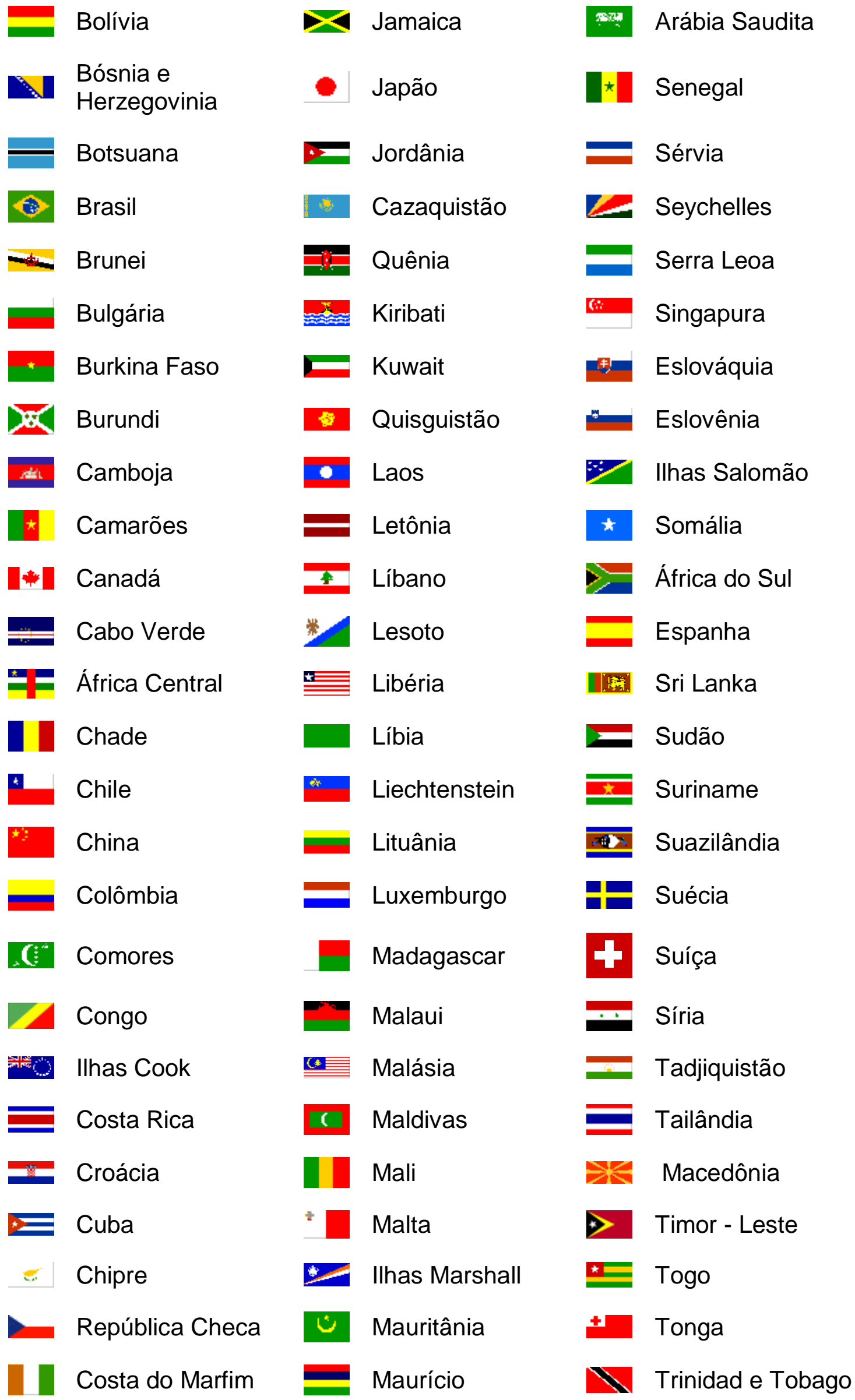


Coréia do

Democrática do Congo

므 Dinamarca

$\gg \quad$ Jibuti

= Dominica

- República

Dominicana

Equador

Egito

El Salvador

Guiné Equatorial

Eritréia

Estônia

Etiópia

União Européia

Fiji

H- Finlândia

França

Gabão

Gâmbia
\& México

Micronésia

Mônaco

目 Mongólia

* Montenegro

Marrocos

Moçambique

\$ Mianmar

2. Namíbia

Nauru

Nepal

Holanda

Nova Zelândia

Nicarágua

Níger

Nigéria

Nive

드 Noruega

Omã
- Tunísia

C* Turquia

Turcomenistão

Tuvalu

틀 Uganda

Ucrânia

Emirados Árabes

彭 Reino Unido

Tanzânia

傁 EUA

Uruguai

Uzbequistão

D Vanuatu

Venezuela

* Vietnã

lêmen

Zâmbia

Zimbábue

$++*$ Geórgia

C Paquistão

Dos países que participaram da reunião, nem todos tomaram a posição de ratificá-la, mesmo tendo assinado o compromisso. Na TAB. 4 apresentamse listados esses países e sua atual situação frente à convenção. 
TABELA 4 - Países/partes que ainda não ratificaram a CQNUMC ${ }^{75}$.

\begin{tabular}{|c|c|c|c|c|}
\hline \multicolumn{4}{|c|}{ Não assinado e não ratificado } & \multirow{2}{*}{$\begin{array}{c}\text { Assinado e com } \\
\text { intenção de ratificar }\end{array}$} \\
\hline$=$ & Afeganistão & $\overline{1}$ & São Marino & \\
\hline & Andorra & $\sum \pm$ & $\begin{array}{l}\text { São Tomé e } \\
\text { Príncipe }\end{array}$ & \\
\hline$-\infty$ & Brunei & & Sérvia & \\
\hline & Chade & $\star$ & Somália & \\
\hline & Comores & & Tadjiquistão & \\
\hline 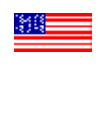 & $\begin{array}{l}\text { EUA - assinou } \\
\text { mas não ratificou }\end{array}$ & & China & \\
\hline+ & Tonga & 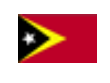 & Timor Leste & \\
\hline & Iraque & C. & Turquia & \\
\hline - & Montenegro & : & Vaticano & \\
\hline & África Central & $\equiv$ & Zimbábue & \\
\hline 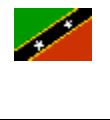 & $\begin{array}{l}\text { São Cristóvão e } \\
\text { Névis }\end{array}$ & & Saara Ocidental & \\
\hline
\end{tabular}

As Partes integrantes da CQNUMC foram subdivididas em Partes Anexo I e Partes Não Anexo I.

Essa divisão teve como objetivo separar alguns critérios, sobretudo a responsabilidade pelo aumento da concentração atmosférica de GEE ${ }^{68}$.

As Partes Anexo I, conforme indicadas na TAB. 5, são aqueles países integrados pelas partes signatárias da CQNUMC pertencentes em 1990 a OCDE e pelos países industrializados da antiga União Soviética e do Leste Europeu.

As Partes Anexo I, é compreendida pelos países industrializados ou desenvolvidos, que possuem metas de limitação ou redução de emissões ${ }^{25}$. 
TABELA 5 - Países/partes que compõem o Anexo I da CQNUMC ${ }^{76}$.

\begin{tabular}{|c|c|c|c|}
\hline \multicolumn{4}{|c|}{ Países do Anexo I } \\
\hline$\because$ & Austrália & & Listenstaine $^{a}$ \\
\hline & Áustria & & Lituânia \\
\hline & Belarus $^{\text {b }}$ & & Luxemburgo \\
\hline & Bélgica & & Mônaco a \\
\hline & Bulgária $^{\text {b }}$ & & Holanda \\
\hline & Canadá & & Nova Zelândia \\
\hline & Croácia $^{\mathbf{a}, \mathbf{b}}$ & & Noruega \\
\hline & República Tcheca $^{\text {a, b }}$ & & Polônia b \\
\hline & Dinamarca & 利 & Portugal \\
\hline & Estônia & & Romênia ${ }^{\text {b }}$ \\
\hline & Comunidade Européia & & Federação Russa ${ }^{\text {b }}$ \\
\hline & Finlândia & 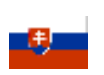 & Eslováquia a \\
\hline & França & & Eslovênia \\
\hline & Alemanha & & Espanha \\
\hline & Grécia & & Suécia \\
\hline & Hungria & & Suíça \\
\hline & Islândia & $C+$ & Turquia \\
\hline & Irlanda & 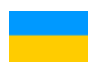 & Ucrânia \\
\hline & Itália & 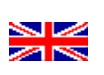 & Reino Unido \\
\hline 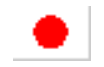 & Japão & 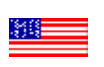 & EUA \\
\hline & Letônia ${ }^{\text {b }}$ & & \\
\hline
\end{tabular}

Legenda:

a - Países que passaram a fazer parte do Anexo I mediante emenda em conformidade com a decisão adotada na COP 3.

b - Países com economia em transição. 
As Partes Não Anexo I, apresentadas na TAB. 6, são todas as partes da CQNUMC não listadas no Anexo I, entre as quais o Brasil, que não possuem metas quantificadas de redução de emissões.

TABELA 6 - Países/partes não Anexo I da CQNUMC ${ }^{77}$.

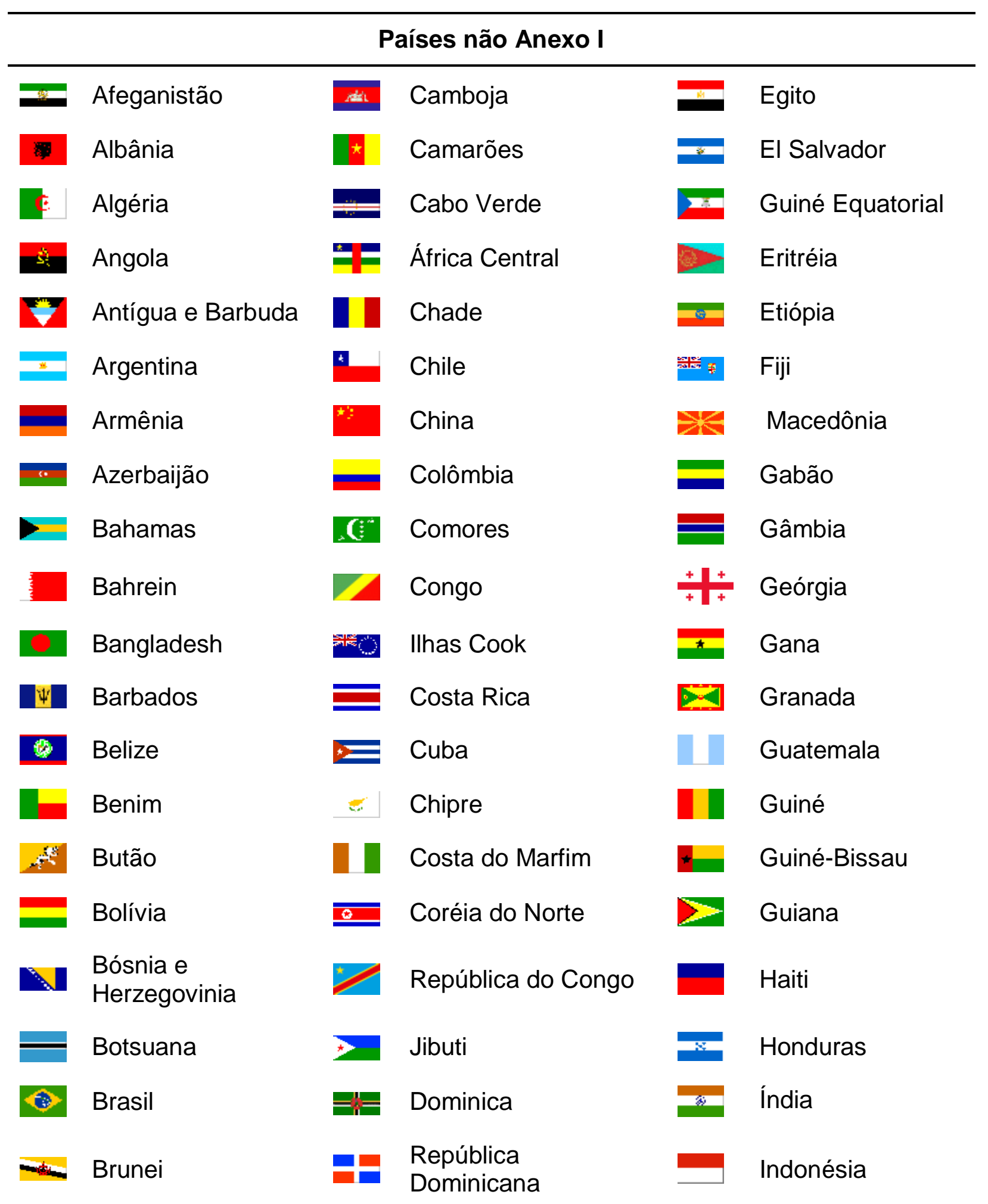




\begin{tabular}{|c|c|c|c|c|c|}
\hline & Burkina Faso & $=$ & Equador & $=$ & Irã \\
\hline 7 & Israel & $=$ & Moçambique & & San Marino \\
\hline$\ll$ & Jamaica & & Mianmar & 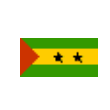 & $\begin{array}{l}\text { Sao Tomé e } \\
\text { Príncipe }\end{array}$ \\
\hline & Jordânia & & Namíbia & & Arábia Saudita \\
\hline$B$ & Cazaquistão & & Nauru & & Senegal \\
\hline & Quênia & & Nepal & & Sérvia \\
\hline 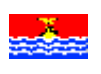 & Kiribati & & Nicarágua & $\longleftarrow$ & Seychelles \\
\hline & Kuwait & & Níger & & Serra Leoa \\
\hline & Quirguistão & & Nigéria & 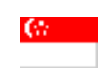 & Cingapura \\
\hline & Laos & 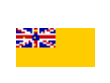 & Niue & F & Ilhas Salomão \\
\hline & Líbano & & Omã & 寻 & África do Sul \\
\hline 枋 & Lesoto & & Paquistão & $\$$ & Montenegro \\
\hline 些 & Libéria & & Palau & & Samoa \\
\hline & Líbia & & Panamá & 国要 & Sri Lanka \\
\hline & Madagascar & & Papua Nova Guiné & & Sudão \\
\hline & Malauí & & Paraguai & $\bar{t}$ & Suriname \\
\hline$\underline{\underline{\underline{\mathbf{G O}}}}$ & Malásia & & Marrocos & $\bar{z}$ & Suazilândia \\
\hline & Maldivas & & Peru & & Síria \\
\hline & Mali & $>$ & Filipinas & & Tadjiquistão \\
\hline & Malta & 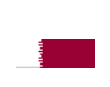 & Qatar & & Tailândia \\
\hline E & Ilhas Marshall & $:$ & República da Coréia & 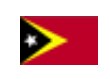 & Timor - Leste \\
\hline c & Mauritânia & & Moldávia & 뜨 & Togo \\
\hline & Maurício & 0 & Ruanda & + & Tonga \\
\hline & México & & São Cristóvão Névis & & $\begin{array}{l}\text { Trinidad e } \\
\text { Tobago }\end{array}$ \\
\hline & Micronésia & $\Delta$ & Santa Lúcia & $\theta$ & Tunísia \\
\hline
\end{tabular}


面 Mongólia

14 São Vincente e Grenadinas

플 Uganda

Emirados Árabes

Tanzânia
Tuvalu

Uruguai

Uzbequistão

D) Vanuatu

... Venezuela
Turcomenistão

* Vietnã

lêmen

Zâmbia

E Zimbábue

Uma das resoluções determinadas nas COP's foi a quantificação das emissões dos GEE. Estabeleceu-se um modelo que as equaliza, usando o $\mathrm{CO}_{2}$ equivalente $\left(\mathrm{CO}_{2}\right.$ eq ou $\left.\mathrm{CO}_{2} \mathrm{e}\right)$, como referência e em toneladas métricas. $\mathrm{O}$ modelo de conversão baseia-se no índice de Potencial de Aquecimento Global (Global Warming Potential, GWP), divulgado pelo IPCC ${ }^{64,78}$ e possibilitando que as reduções de diferentes gases sejam somadas. O GWP deve ser utilizado para o primeiro período de compromisso e apresenta-se indicado na TAB. 7.

TABELA 7 - Modelo para cálculo de emissões de $\mathrm{CO}_{2}$ eq ${ }^{19}$.

\begin{tabular}{cc}
\hline Gases de Efeito Estufa & Referência na GWP $^{\text {a }}$ \\
\hline $\mathrm{CO}_{2}$ & $\mathrm{x}^{\mathrm{b}} 1$ \\
$\mathrm{CH}_{4}$ & $\times 21$ \\
$\mathrm{~N}_{2} \mathrm{O}$ & $\times 310$ \\
$\mathrm{HFC}-23$ & $\times 11.700$ \\
$\mathrm{HFC}-125$ & $\times 2.800$ \\
$\mathrm{HFC}-131^{\mathrm{a}}$ & $\times 1.300$ \\
$\mathrm{HFC}-142^{\mathrm{a}}$ & $\times 140$ \\
$\mathrm{CF}_{4}$ & $\times 6.500$ \\
$\mathrm{C}_{2} \mathrm{~F}_{6}$ & $\times 9.200$ \\
$\mathrm{SF}_{6}$ & $\times 23.900$ \\
\hline
\end{tabular}

Legenda:

a - GWP relativo ao $\mathrm{CO}_{2}$ expresso em termos de massa e para um período de 100 anos definido pelo Segundo Relatório de Avaliação do IPCC (1995). b- indica multiplicado por. 


\section{3. 3. Breve histórico das Conferências das Partes ${ }^{65,74,79,80,81,82}$}

i. COP 1 - Berlim, Alemanha - Realizada de 28/03 a 07/04 e 1995, no ano seguinte da entrada em vigor da CQNUMC, contando com representantes de 117 países, onde foi estabelecido o Mandato de Berlim, que teve como foco principal o consenso de se apresentar no encontro de 1997 um documento tornando oficial o comprometimento dos países do Anexo I de redução das emissões de gases do efeito estufa. Eram os primeiros passos para a criação do Protocolo de Kyoto.

A COP-1 também aprovou o desenvolvimento das Atividades Implementadas Conjuntamente (Activities Implemented Jointly) em fase piloto, que seriam estabelecidas entre um país do Anexo I e outro não pertencente a esse grupo, visando a implantação de projetos de suporte e transferência de tecnologia, com o objetivo de facilitar o cumprimento de metas de mitigação ${ }^{83}$.

ii. COP 2 - Genebra, Suiça - O encontro ocorreu de 08 a 19/06 de 1966 e teve como documento oficial a Declaração de Genebra e como destaque foi decidido que os países não-Anexo I, que não possuem metas de redução de emissões, poderiam enviar uma comunicação preliminar a CQNUMC, solicitando auxílio financeiro e tecnológico advindo do Fundo Global para o Meio Ambiente (GEF); para o desenvolvimento de programas de redução de emissões ${ }^{84}$.

iii. COP 3 - Kyoto, Japão - O Protocolo de Kyoto - Realizada de 01 a 12/12 de 1997, permeou a adoção das metas da CQNUMC e levou à tomada de ações mais objetivas e concretas no combate ao problema do aquecimento global. As 159 Partes envolvidas nessa COP 3, em resposta aos avanços científicos e disposições políticas, culminaram na adoção, por consenso, deste protocolo que ficou como um dos marcos mais importantes desde a criação da CQNUMC no combate à mudança climática. 
O Protocolo de Kyoto elaborou mecanismos de flexibilização para que se atingissem as metas de redução de emissões. De modo geral, definiu-se que os países industrializados (Anexo I), reduziriam suas emissões combinadas de GEE em 5,2\% em relação aos níveis de 1990. Alguns países assumiram compromissos maiores: Japão 6\%, União Européia - 8\% e Estados Unidos - 7\%, que acabaram não ratificando o acordo, retirando-se em 2001. Outros países como Ucrânia e Federação Russa não assumiram nenhum compromisso de redução, e outros como Noruega, Islândia e Austrália, ainda poderiam aumentar suas emissões.

A entrada em vigor do acordo estava vinculada à ratificação por no mínimo 55 países que somassem $55 \%$ das emissões globais de gases do efeito estufa, o que aconteceu apenas em 16 de fevereiro de 2005, após vencida a relutância da Rússia. Ao ser ratificado, o Protocolo passou a vigorar no prazo de 90 dias da data de ratificação, significando que havia um compromisso legal vinculando todas as Partes envolvidas e a não complacência de alguma Parte estaria sujeita a penalidades dentro do Protocolo ${ }^{85}$.

v. COP 4 - Buenos Aires, Argentina - A COP 4 ocorreu de 02 a 13/11 de 1998 e centrou esforços na implementação e ratificação do pacote elaborado no Protocolo de Kyoto, adotado na COP-3.

Com essa perspectiva ficou conhecido como Plano de Ação de Buenos Aires e trouxe um programa de metas para a abordagem de alguns itens do Protocolo, tratados em separado: análise de impactos da mudança do clima e alternativas de compensação; atividades implementadas conjuntamente (AIC); mecanismos financiadores; desenvolvimento e transferência de tecnologia aos países em desenvolvimento e/ou mais suscetíveis aos impactos ambientais, além da complacência, políticas e medidas voltados à mitigação de mudança climática ${ }^{86,87}$.

vi. COP 5 - Bonn, Alemanha - O encontro ocorreu na Alemanha de 25/10 a 05/11 de 1999 e teve como destaque a implementação do 
Plano de Ações de Buenos Aires. Discutiram-se também questões relativas ao Uso da Terra, Mudança de Uso da Terra e Florestas (LULUCF).

A COP-5 tratou ainda da execução de atividades implementadas conjuntamente (AIC) em caráter experimental e do auxílio para capacitação de países em desenvolvimento ${ }^{68,88}$.

vii. COP 6 - Haia, Países Baixos - A Conferência ocorreu de 13 a 24/11 de 2000 e foi marcada por muitas dificuldades e divergências de consenso em torno das questões em pauta, levando à suspensão das negociações. Em virtude disso, o Presidente da COP 6, Jan Pronk, divulgou uma nota onde comunicava que metas importantes permaneceriam sem solução.

A falta de acordo em relação ao Plano de Ação de Buenos Aires, nas discussões sobre sumidouros, na LULUCF, no Mecanismo de Desenvolvimento Limpo, no Comércio de Emissões e nos financiamentos de países em desenvolvimento, estabeleceu uma segunda fase da COP- 6, em Bonn, na Alemanha, em julho de 2001, após a saída dos Estados Unidos do Protocolo de Kyoto ${ }^{89}$.

viii. COP-6-bis - Bonn, Alemanha - Sob um clima de incertezas, principalmente devido à renúncia dos EUA, a reconvocação da COP 6-bis ocorreu de 16 a 27/07 de 2001, superou as expectativas e acabou marcando o sucesso do Protocolo de Kyoto. Isso se deveu às concessões que foram feitas para agradar os países em conflito, tais como o uso de sumidouros de carbono (sinks), garantindo a geração de créditos de carbono aos países do Grupo Umbrella, que somente assim se dispuseram a participar da COP6-bis e apoiar o Protocolo de Kyoto.

Nesse clima mais saudável, reforçou-se a abordagem e o consenso de pontos essenciais do Plano de Ação de Buenos Aires, estabelecendo-se afinal algumas questões cruciais como: a necessidade da criação de um fundo especial para Mudanças Climáticas além do GEF; ao fato de que as Partes incluídas no 
Anexo II e Anexo I, quando possível devem financiar países em desenvolvimento diretamente através do fundo especial para mudança climática, do reabastecimento do GEF, e de canais unilaterais e multilaterais e devem ser desenvolvidas modalidades apropriadas para a divisão da responsabilidade entre os Países do Anexo II ${ }^{68,90}$.

ix. COP 7 - Marrakech, Marrocos - Realizada de 29/10 a 09/11 de 2001, a reunião definiu regras que viabilizassem o Acordo de Bonn e o Protocolo de Kyoto. Ainda dessa vez os Países da União Européia e os G77/China sentiram-se obrigados a ouvir as exigências dos países do Grupo Umbrella que não queriam eleger critérios nítidos para diversas metas.

Porém, o Grupo Umbrella não foi atendido em suas apelações e o impasse foi resolvido com concessões de ambos os lados, fechando o então chamado Acordo de Marrakech que definiu regras operacionais para: os mecanismos de flexibilização; criou limites no uso de créditos de carbono gerados de projetos florestais e de agricultura; serão permitidos projetos unilaterais de MDL (sem a participação de um país do Anexo I) e o estabelecimento de fundos de ajuda a países em desenvolvimento voltados a iniciativas de adaptação às mudanças climáticas ${ }^{91}$.

x. COP 8 - Conferência de Nova Delhi, Índia - realizada de 23/10 a 01/11 de 2002, mesmo ano da Cúpula Mundial sobre Desenvolvimento Sustentável (Rio+10), contou com 4.352 participantes de 167 Partes e 213 organizações não-governamentais e inter-governamentais.

Nela tentaram-se discutir, sem sucesso, muitas questões pendentes do Acordo de Marrakech como florestas, permanência, adicionalidade, linha de base, vazamentos (“leakages"), período de creditação, entre outros. Devido aos desacordos entre os participantes, nenhum resultado concreto foi obtido, ficando então 
acordado que tais questões seriam concluídas durante a próxima Conferência.

$\mathrm{Na}$ COP 8 houve aconteceu apenas um ponto positivo que se deveu à apresentação de diversos projetos na mesma linha do MDL, trazendo à tona a formação de mercados para o comércio de créditos de carbono e criando iniciativas como o PCF - Prototype Carbon Fund, o CO2e.com, CCX - Chicago Climate Exchange entre outros $^{92}$.

xi. $\quad$ COP 9 - Conferência de Milão, Itália - A 9a COP ocorreu de 01 a 12/12 de 2003, reunindo 180 países. No encontro foram definidas questões pendentes importantes como: a condução junto à Convenção do Clima para obtenção de créditos de carbono em projetos de florestamento e reflorestamento; os limites de projetos de reflorestamento; a adoção de RCEs temporárias (válidas para o Primeiro Período de Compromisso); projetos florestais de longo prazo e projetos florestais de pequena escala ${ }^{93,94}$.

xii. COP 10 - Conferência de Buenos Aires, Argentina - Realizada de 06 a 17/12 de 2004, a reunião aprovou regras para a implementação do Protocolo de Kyoto, que entrou em vigor no início do ano seguinte, após a ratificação pela Rússia. Outros destaques da COP-10 foram a definição dos Projetos Florestais de Pequena Escala (PFPE) e a divulgação de inventários de emissão de gases do efeito estufa por alguns países em desenvolvimento, entre eles o Brasil ${ }^{95,96}$.

xiii. COP 11 - Conferência de Montreal, Canadá - Ocorreu de 03 a 10/12 de 2005, juntamente com a Primeira Conferência das Partes do Protocolo de Kyoto (COP/MOP1). Já entra na pauta a discussão do segundo período do Protocolo, após 2012, para o qual instituições européias defendem reduções de emissão na ordem de 20 a 30\% até 2030 e entre 60 a $80 \%$ até $2050{ }^{97}$. 
xiv. COP 12 - Conferência de Nairobi, Quênia - Realizada de 06 a 17/11 de 2006, a reunião teve como principal compromisso a revisão de prós e contras do Protocolo de Kyoto, com um esforço das 189 nações participantes de realizarem internamente processos de revisão ${ }^{98}$.

xv. COP 13 - Conferência de Bali, Indonésia - O encontro aconteceu de 03 a 14/12 de 2007 e estabeleceu compromissos mensuráveis, transparentes e verificáveis para a redução de emissões causadas por desmatamento das florestas tropicais para o acordo que substituirá o Protocolo de Kyoto. Esse é um dos pontos que integram o processo oficial de negociação para o próximo acordo, que deve ser concluído até 2009 e cujas bases foram estabelecidas pelo texto final da COP-13, o que Ihe valeu o apelido de Mapa do Caminho. Também foram aprovados e entraram no texto final, a implementação efetiva do Fundo de Adaptação, para que países mais vulneráveis à mudança do clima enfrentassem seus impactos, além de constarem diretrizes para que os países desenvolvidos transferissem tecnologias limpas aos países em desenvolvimento. Não foram apontadas quais as fontes e o volume de recursos suficiente para essas e outras diretrizes, tais como o apoio no combate ao desmatamento nos países em desenvolvimento e outras ações de mitigação. A anuência dos países em desenvolvimento na questão do desmatamento, entre eles o Brasil, que era contra essa diretriz, abre espaço para que os Estados Unidos deixem de bloquear o Protocolo de Kyoto. Um dos argumentos para não ratificar o acordo era a falta de engajamento das Partes não-Anexo I nos compromissos de mitigação. Mas a bastante criticada posição norte-americana de colocar empecilhos à Conferência de Bali colaborou para o principal revés do encontro: o adiamento para 2050 de metas compulsórias claras para redução de emissões, deixando de lado a proposta de metas entre $25 \%$ e $40 \%$ para $2020{ }^{99}$. 
xvi. COP 14 - Conferência de Poznan, Polônia - De 01 a 12/12 de 2008, representantes de 192 nações reuniram-se para negociar acordos em questões importantes e ampliar a cooperação internacional no enfrentamento da maior crise ambiental do planeta: o aquecimento da atmosfera e as mudanças de clima.

Foram discutidos temas como a redução de emissões por desmatamento e degradação, a transferência de tecnologia entre países, o financiamento de ações de mitigação e adaptação, as metas quantitativas de redução de emissões de gases de efeito estufa e a criação de um fundo de adaptação. O principal objetivo dessa COP-14, era o de estruturar um novo acordo em substituição ao Protocolo de Kyoto, que seria então ratificado na próxima cúpula de Copenhague em 2009. O encontro foi marcado por um forte impasse entre nações industrializadas e países emergentes e em desenvolvimento quanto à formulação das regras relativas ao Fundo de Adaptação, com o qual países desenvolvidos oferecerão ajuda aos países em desenvolvimento e/ou subdesenvolvidos a lidar com as conseqüências da mudança climática.

Enquanto os últimos cobram um acesso desburocratizado ao Fundo, os países desenvolvidos mantiveram uma postura de luta por manter o controle sobre seu regulamento. Só nas últimas horas é que os negociadores chegaram a um acordo, de forma que ao menos o Fundo poderá entrar em funcionamento, chegando-se a um valor de apenas 60 milhões de euros anuais ${ }^{100}$.

\section{4. O Protocolo de Kyoto ${ }^{63}$}

Uma série de acidentes industriais graves e derramamentos de quantidades consideráveis de petróleo no mar, ocorridos a partir do final da década de 1960, estão apresentados na TAB. 8 e fizeram com que os problemas ambientais passassem a ganhar uma dimensão internacional, levando a um questionamento sobre as conseqüências do modelo de desenvolvimento até então adotado. 
TABELA 8 - Retrospectiva da história ambiental recente ${ }^{101}$.

\begin{tabular}{|c|c|c|}
\hline $\begin{array}{l}\text { Episódio de poluição } \\
\text { décadas } 60 \text { a } 90\end{array}$ & Reuniões e documentos & Comentários \\
\hline 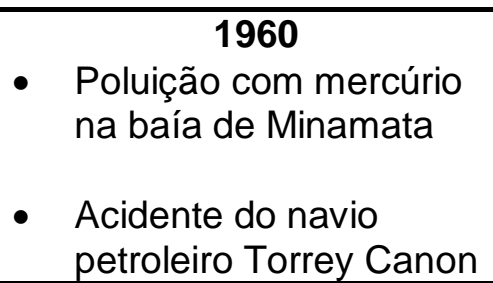 & $\begin{array}{l}\text { - Criação da EPA } \\
\text { - Publicação do estudo } \\
\text { "Limits to Growth" }\end{array}$ & $\begin{array}{l}\text { - Primeiros movimentos } \\
\text { ambientalistas }\end{array}$ \\
\hline 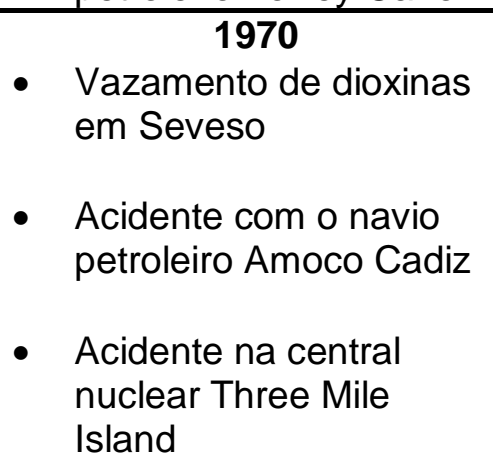 & $\begin{array}{l}\text { - Primeiro selo ecológico } \\
\text { (Blauer Engel) }\end{array}$ & $\begin{array}{l}\text { - Uso racional da energia } \\
\text { - Fontes renováveis } \\
\text { - Valorização energética } \\
\text { de resíduos }\end{array}$ \\
\hline \begin{tabular}{ll} 
& \multicolumn{1}{c}{1980} \\
- & Acidente na planta de \\
pesticida da Union \\
Carbide em Bophal
\end{tabular} & $\begin{array}{l}\text { - Relatório Brundtland } \\
\text { - Protocolo de Montreal } \\
\text { - Primeiro informe do } \\
\text { IPCC } \\
\text { - Convenção de Basiléia }\end{array}$ & $\begin{array}{l}\text { - Desenvolvimento } \\
\text { sustentável } \\
\text { - Legislação ambiental } \\
\text { (ElA/RIMA) } \\
\text { - Lei Superfund sobre } \\
\text { áreas contaminadas } \\
\text { - Globalização das } \\
\text { questões ambientais }\end{array}$ \\
\hline $\begin{array}{c}1990 \\
\text { - } \quad \text { Guerra do Golfo }\end{array}$ & $\begin{array}{l}\text { - } \text { CNUMAD - Rio } 92 \\
\text { - } \text { BS } 7750 \\
\text { - } \text { ISO } 1400 \\
\text { - Protocolo de Kyoto }\end{array}$ & $\begin{array}{l}\text { - Prevenção da poluição } \\
\text { - Geranciamento } \\
\text { ambiental } \\
\text { - Qualidade ambiental } \\
\text { - Ecologia industrial }\end{array}$ \\
\hline
\end{tabular}

Deste modo, desenvolvimento econômico e proteção ambiental passaram a ser vistos como antagônicos, mas que precisavam ser conciliados.

O Protocolo de Kyoto foi o resultado da $3^{\text {a }}$ Conferência das Partes da Convenção das Nações Unidas sobre Mudanças Climáticas, realizada no Japão, em 1997, após discussões que se estendiam desde $1990{ }^{63}$. A conferência reuniu 
representantes de 166 países para discutir providências em relação ao aquecimento global $^{16,102}$.

Como já comentado, as atividades econômicas e industriais têm provocado alterações na biosfera, resultando na quase duplicação da concentração de GEE na atmosfera durante o período de 1750 a 1998. Na TAB. 9 apresentam-se essas medições ${ }^{103,102}$.

TABELA 9 - Concentrações globais de alguns GEE de atividades antrópicas

\begin{tabular}{lccc}
\hline & $\begin{array}{c}\mathbf{C O}_{\mathbf{2}} \\
\text { (gás carbônico) }\end{array}$ & $\begin{array}{c}\mathbf{C H}_{\mathbf{4}} \\
\text { (metano) }\end{array}$ & $\begin{array}{c}\mathbf{N}_{\mathbf{2}} \mathbf{O} \\
\text { (óxido nitroso) }\end{array}$ \\
\hline Concentração em 1750 & $280[\mathrm{ppm}]$ & $700[\mathrm{ppb}]$ & $270[\mathrm{ppb}]$ \\
Concentração em 1998 $^{\text {(moxa de alteração }}{ }^{\mathbf{a}}$ & $365[\mathrm{ppm}]$ & $1745[\mathrm{ppb}]$ & $314[\mathrm{ppb}]$ \\
Taxa $^{\text {Residência na atmosfera }}$ & $1,5[\mathrm{ppm} / \mathrm{ano}]^{\mathbf{b}}$ & $7,0[\mathrm{ppb} / \mathrm{ano}]^{\mathbf{b}}$ & $0,8[\mathrm{ppb} / \mathrm{ano}]$ \\
\hline
\end{tabular}

Legenda:

[ppm] = partes por milhão; ppb= partes por bilhão.

a - Calculada durante o período de 1900 a 1999.

b - A taxa de $\mathrm{CO}_{2}$ tem flutuado entre 0,9 e 2,8 ppm/ano e para $\mathrm{CH}_{4}$, entre 0 e 13 ppb/ano no período de 90-99.

O relatório elaborado pelo Protocolo de Kyoto estabelece a redução das emissões de $\mathrm{CO}_{2}$, que respondem por $75 \%$ do total das emissões relacionadas ao aquecimento global, e outros GEE, nos países industrializados (Anexo I) ${ }^{3}$.

Define ainda que, durante o primeiro período de compromisso (2008 2012), as Partes/Países do Anexo I signatárias de Kyoto, reduzam em pelo menos $5 \%$ (cindo por cento) suas emissões combinadas de GEE em relação aos níveis de 1990, ano em que estes Países emitiram 3,87 bilhões toneladas de carbono equivalente ${ }^{16,37,105,104}$.

O conceito básico acertado para Kyoto é o da "responsabilidade comum, porém diferenciada" ${ }^{15}$ ou seja, todos os países têm responsabilidade no combate ao aquecimento global, mas os que mais contribuíram historicamente para 0 
acúmulo de gases na atmosfera, ou seja, os países industrializados ou os países do Anexo I têm obrigação maior de reduzir suas emissões ${ }^{106}$.

As Partes/Países acordaram, dentre outras decisões, que: ${ }^{107,108}$

i. a maior parte das históricas e atuais emissões dos GEE é originária dos Países Anexo I;

ii. as emissões 'per capita' nos Países Não Anexo I ainda são relativamente baixas;

iii. a parcela e emissões globais originárias dos Países Não Anexo I crescerão para atender as necessidades sociais de desenvolvimento;

iv. Países Não Anexo I não foram incluídos em qualquer limitação numérica do Protocolo de Kyoto, porque eles não eram contribuintes principais para as emissões de gases de efeito estufa no período pré-industrialização do tratado; ${ }^{37}$

v. a implementação para alcançar os objetivos do Protocolo, para a elaboração de políticas e medidas que reduzam os GEE, aumentando a absorção desses gases e utilizar todos os mecanismos disponíveis, os chamados "mecanismos de flexibilização" tais como a Implementação Conjunta, o Mecanismo de Desenvolvimento Limpo ${ }^{16}$ e o Comércio de Emissões, sendo recompensado com créditos.

Portanto, Países não Anexo I, como Brasil, China e Índia, participam do acordo, mas não são obrigados a atingir metas de redução e nem possuem objetivos quantitativos específicos para isso, já que estes Países irão aumentar suas emissões para que atinjam níveis de desenvolvimento que permitam reduzir a pobreza de suas populações ${ }^{109}$.

Um dos dados mais alarmantes que estão surgindo no cenário mundial, que se torna uma crescente ameaça às pretensões do Protocolo de Kyoto, segundo o Center for Global Development, foi que, a partir de 27 de agosto de 2008, a China, ultrapassou os EUA como o maior emissor de $\mathrm{CO}_{2}$ na geração de energia, em sua busca pela igualdade com os países desenvolvidos em termos de melhorar a qualidade de vida como um todo ${ }^{108,110}$. 
Porém, de forma inevitável, a forte e contínua dependência do uso do carvão e outros combustíveis fósseis, projetada para os países em desenvolvimento (não-Anexo I), tenderá a aumentar substancialmente as emissões mundiais do dióxido de carbono, conforme projeções realizadas pelos DOE e EIA, e mostrados na FIG. $8^{111}$.

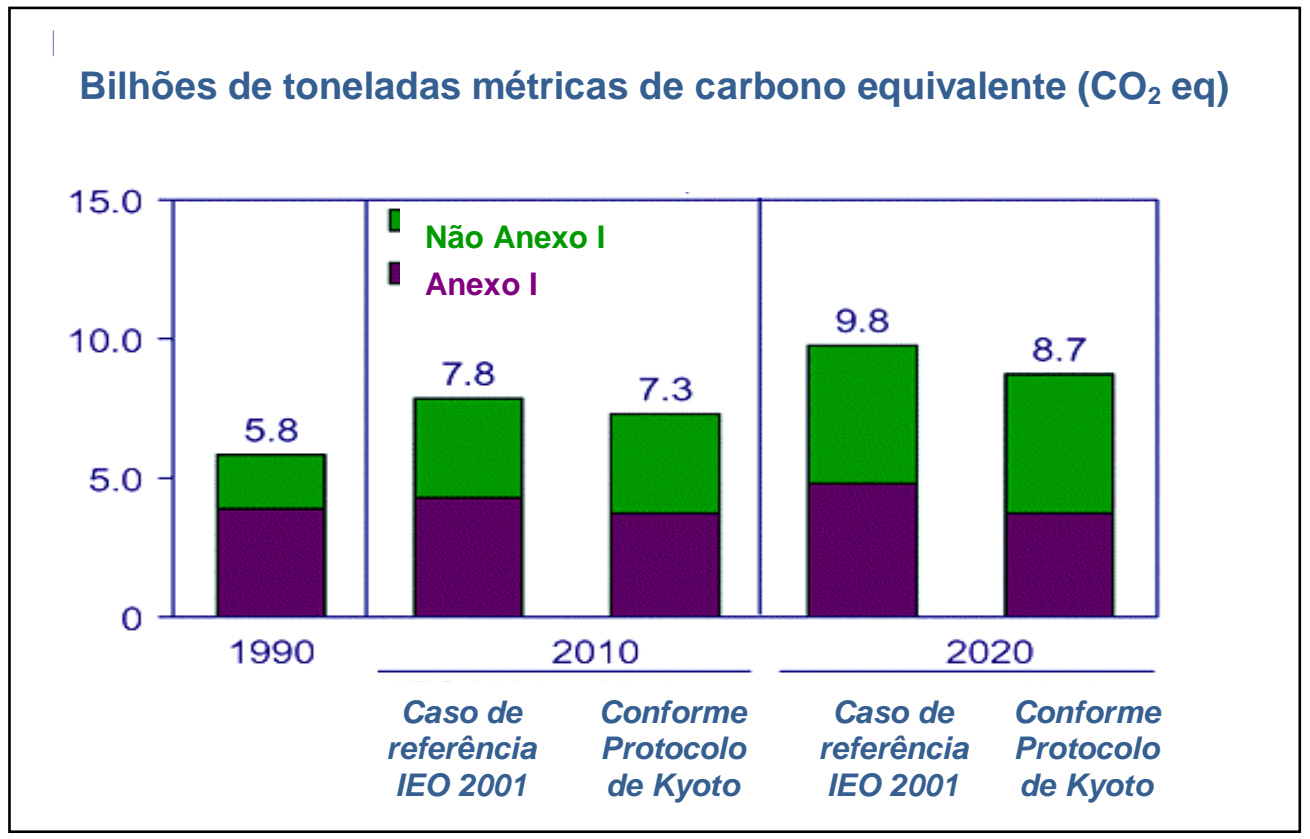

FIGURA 8 - Emissões mundiais de $\mathrm{CO}_{2}$ no caso de referência do International Energy Outlook - IEO 2001 e sob o Protocolo de Kyoto, 2010 e 2020.

Para que o Protocolo entrasse em vigor, deveria ser ratificado por 55 Países/Partes, incluindo os que, juntos, produziram $55 \%$ do gás carbônico lançado na atmosfera em $1990{ }^{112}$.

A União Européia já apoiara o protocolo, mas os EUA - o maior poluidor da época (em 1990 eram responsáveis por 36,1\% das emissões dos GEE ${ }^{86}$ ) - se negou a assiná-lo. O país desistiu do tratado em 2001, alegando que o pacto era caro demais. O então presidente americano, George W. Bush, afirmou haver ausência de provas de que o aquecimento global estivesse relacionado à poluição industrial e que cortes prejudicariam a economia do país, altamente dependente de combustíveis fósseis ${ }^{113}$.

Outro argumento bastante utilizado para sua não adesão é que o acordo excluía de maneira injusta os países que se encontravam em desenvolvimento, devido ao aumento significativo em suas emissões, principalmente pelo grande 
avanço das economias emergentes. Países em desenvolvimento como China, Índia e Brasil, por exemplo, deveriam juntar-se ao Anexo I já na primeira fase de compromisso ${ }^{113}$.

Segundo esta visão, em lugar de utilizar uma análise histórica das emissões, que relaciona o grau de desenvolvimento dos países com sua contribuição para a concentração atual de GEE, o foco deveria estar nas emissões presentes, as quais estão se acelerando nos países em desenvolvimento.

Só em 2004, no entanto a cota foi finalmente atingida e o pacto conseguiu sua implementação com a adesão da Rússia, o segundo maior poluidor na época, responsável por $17 \%$ das emissões. O presidente Vladimir Putin finalmente assinou o Protocolo no dia 5/11/2004 ${ }^{114}$.

Até então, apesar da adesão de 127 países, a soma de emissões era de apenas 44\%. Com a Rússia, esse índice chegou a $61 \%{ }^{103}$.

O acordo, ratificado por 141 países, entrou em vigor em 16 de fevereiro de 2005, noventa dias após o processamento dos documentos da adesão da Rússia junto à Organização das Nações Unidas (ONU).

No Brasil, o Protocolo foi assinado em 29 de abril de 1998, ratificado no dia 19 de junho de 2002 e sancionado pelo Presidente da República em 23 de julho do mesmo ano ${ }^{115,122}$.

Atingindo-se a meta pretendida, os países signatários do Anexo I deveriam colocar em ação planos de substituição de energia para deter a escalada das emissões de GEE.

Essas reduções envolveriam as atividades econômicas, especialmente de energia e transportes.

O Protocolo de Kyoto define um "mecanismo de cumprimento" e, como uma vigilância da conformidade "com os compromissos e penalidades pelo não cumprimento", estabelece que, se um país com compromisso de redução de emissão de GEE, não alcançar seu objetivo, este deverá compensar a diferença com um acréscimo de $30 \%$ em sua meta de redução no segundo período de compromisso, definido entre 2013 e $2017^{116}$.

Este país deverá então formular um plano de ação para o cumprimento de sua obrigação, além de ficar suspensa sua permissão para vender créditos mediante o comércio de emissões ${ }^{37}$. 
Todas as considerações citadas acima, embasam-se, principalmente nos Artigos 2 e 3 estabelecidos pelo Protocolo de Kyoto 117,118,119,120.

(A) Artigo 2, parágrafo 1:

1. Cada Parte do Anexo I, ao procurar atingir os seus compromissos quantificados de limitação e redução das emissões nos termos do artigo 3, promovendo o desenvolvimento sustentável, compromete-se a:

(a) Implementar e/ou aprimorar políticas e medidas de acordo com suas circunstâncias nacionais, tais como:

i. o aumento da eficiência energética em setores relevantes da economia nacional;

ii. a proteção e o aumento de sumidouros e reservatórios de GEE estufa, considerando seus compromissos assumidos em acordos internacionais sobre o meio ambiente;

iii. a promoção de formas sustentáveis de agricultura à luz das considerações sobre a mudança do clima;

iv. a pesquisa, o desenvolvimento e o aumento de formas novas e renováveis de energia, que envolvam eficientemente tecnologias de seqüestro de $\mathrm{CO}_{2}$, ambientalmente seguras e que sejam avançadas e inovadoras;

v. a redução gradual ou eliminação de imperfeições de mercado, de incentivos fiscais, de isenções tributárias e tarifárias e de subsídios para todos os setores emissores de gases de efeito estufa que sejam contrários ao objetivo da Convenção e aplicação de instrumentos de mercado;

vi. o estímulo a reformas adequadas em setores relevantes, visando a promoção de políticas e medidas que limitem ou reduzam emissões de gases de efeito estufa não controlados pelo Protocolo de Montreal; 
vii. medidas para limitar e/ou reduzir as emissões de gases de efeito estufa não controlados pelo Protocolo de Montreal no setor de transportes;

viii. a limitação e/ou redução de emissões de metano por meio de sua recuperação e utilização no tratamento de resíduos, bem como na produção, no transporte e na distribuição de energia.

(b) Cooperar com outras Partes do Anexo I no aumento da eficácia individual e combinada de suas políticas e medidas adotadas. Para isso as Partes adotarão medidas, dividindo experiências e informações sobre tais políticas e medidas, desenvolvendo formas de melhorar sua comparabilidade, transparência e eficácia. $A$ Conferência das Partes deve, em sua primeira sessão, considerar maneiras de facilitar tal cooperação, levando em conta toda a informação relevante.

(B) Artigo 3, parágrafo 1:

1. As Partes incluídas no Anexo I devem, individual ou conjuntamente, assegurar que suas emissões antrópicas expressas em $\mathrm{CO}_{2}$ eq, dos GEE listados no Anexo A não excedam suas quantidades atribuídas, calculadas em conformidade com seus compromissos de redução descritos no Anexo B e de acordo com as disposições deste Artigo, com vistas a reduzir suas emissões totais desses gases em pelo menos $5 \%$ abaixo dos níveis de 1990 no período de compromisso de 2008 a 2012.

O Anexo A, citado no Artigo 3 do Protocolo de Kyoto, determina além dos GEE, os principais setores e atividades envolvidos nessas reduções, conforme apresenta-se na TAB 10. 
Tabela 10 - Anexo $A$ - Setores e Fontes de Atividades de redução e remoção de GEE do Protocolo de Kyoto ${ }^{84,121}$.

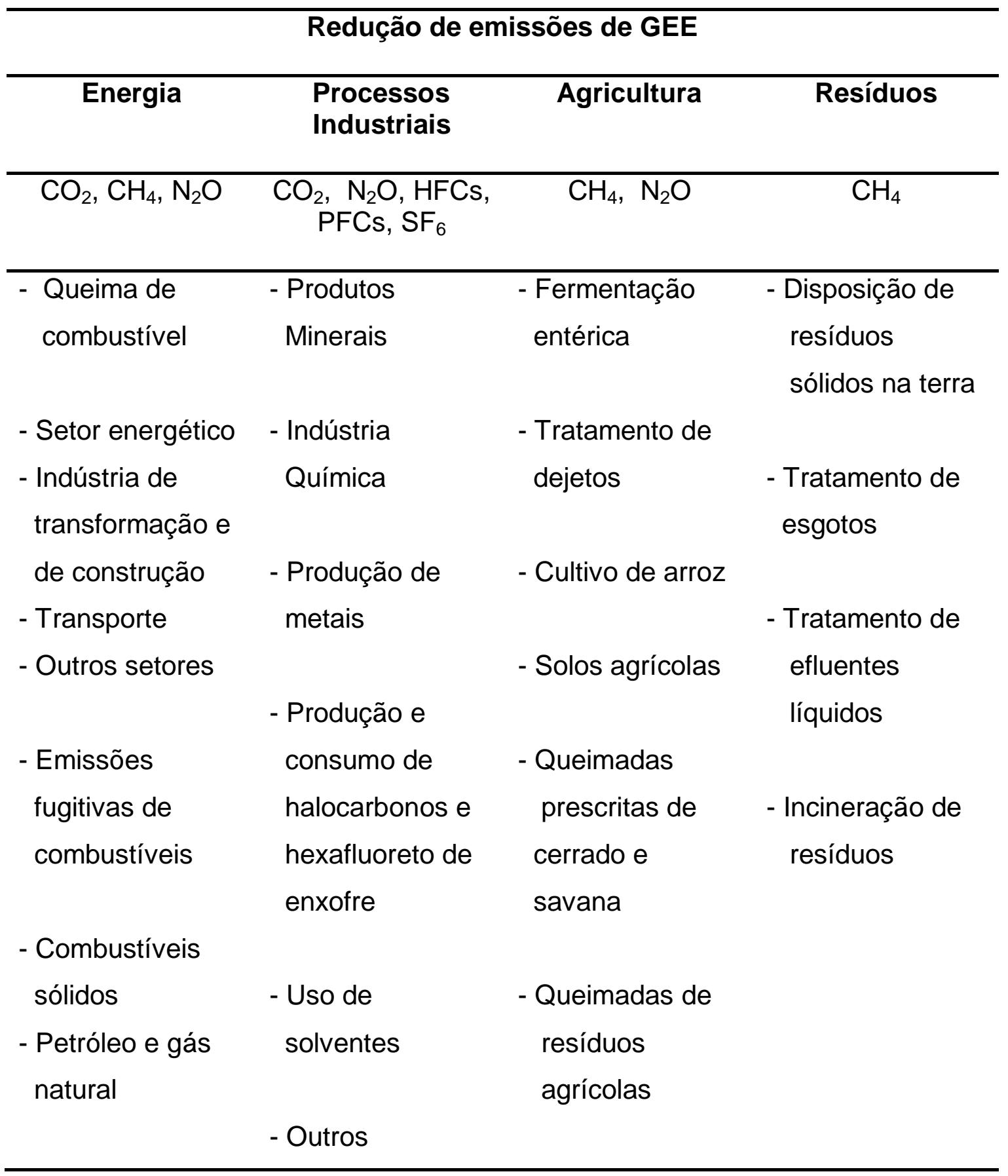

O Anexo B, citado no Artigo 3 do Protocolo de Kyoto, define as metas de redução quantificada de emissões de GEE, exclusivas das partes do Anexo I da CQNUMC. Na TAB. 11 apresentam-se essas metas. 
TABELA 11 - Anexo $B$ - Países com compromisso de redução ou limitação quantificada de emissões ${ }^{123,124,125}$.

\begin{tabular}{|c|c|c|c|c|c|c|}
\hline Anexo I & $\begin{array}{l}\text { Ano } \\
\text { base }\end{array}$ & $\begin{array}{c}\text { Redução } \\
(\%)\end{array}$ & & Anexo I & $\begin{array}{l}\text { Ano } \\
\text { base }\end{array}$ & $\begin{array}{c}\text { Redução } \\
\text { (\%) }\end{array}$ \\
\hline Alemanha & 1995 & 79 & $2 \times$ & Liechtenstein & 1990 & 92 \\
\hline Austrália & 1990 & 108 & & Lituânia * & 1995 & 92 \\
\hline Áustria & 1990 & 87 & & Luxemburgo & 1995 & 72 \\
\hline Bélgica & 1995 & 92,5 & & Mônaco & 1995 & 92 \\
\hline Bulgária * & 1995 & 92 & & Holanda & 1995 & 94 \\
\hline Canadá & 1990 & 94 & & Nova Zelândia & 1990 & 100 \\
\hline Croácia * & & 95 & & Noruega & 1990 & 101 \\
\hline $\begin{array}{l}\text { República } \\
\text { Tcheca* }\end{array}$ & 1995 & 92 & & Polônia * & 1995 & 94 \\
\hline Dinamarca & 1995 & 79 & & Portugal & 1995 & 127 \\
\hline Estônia * & 1995 & 92 & & Romênia * & 1989 & 92 \\
\hline União Européia & $\begin{array}{c}1990 / \\
95\end{array}$ & 92 & & Federação Russa* & 1995 & 100 \\
\hline Finlândia & 1995 & 100 & & Eslováquia * & 1990 & 92 \\
\hline França & 1990 & 100 & & Eslovênia * & 1995 & 92 \\
\hline Grécia & 1995 & 125 & & Espanha & 1995 & 115 \\
\hline Hungria * & 1995 & 94 & & Suécia & 1995 & 104 \\
\hline Islândia & 1990 & 110 & & Suíça & 1990 & 92 \\
\hline Irlanda & 1995 & 113 & & Ucrânia * & 1990 & 100 \\
\hline Itália & 1990 & 93,5 & sers & Reino Unido & 1995 & 87,5 \\
\hline Japão & 1994 & 95 & 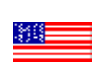 & EUA & 1990 & 93 \\
\hline Letônia * & 1995 & 92 & & & & \\
\hline
\end{tabular}

Legenda: (1) * Países em processo de transição para uma economia de mercado.

(2) Os dados são do ano de referência, conforme determinado durante o processo de revisão inicial.

(3) Embora listados no Anexo I, Belarus e Turquia não estão incluídas no Anexo B do Protocolo, pois não eram partes na Convenção quando ele foi adotado. 


\section{4. 1. Mecanismos de flexibilização ${ }^{65,68,112,126,127}$}

Com a preocupação mundial quanto à limitação de emissão de GEE, a poluição passou a ter um valor para todos os países, mas com maior peso para os países em desenvolvimento. Estes últimos deverão cumprir as metas apresentadas no Protocolo, investindo em tecnologias mais eficientes em termos de emissão de GEE em seus próprios territórios e/ou utilizar os mecanismos de flexibilização previstos e implantar, a custos mais baixos, mudanças tecnológicas em outros países.

Tais mecanismos consideram não só a redução das emissões em si, mas também o campo econômico, visto que são alternativas que permitem a minimização de custos.

Nesse sentido, o Protocolo de Kyoto estabeleceu, como complementação às medidas e políticas domésticas, obrigatoriamente tomadas pelas Partes Anexo I em reduzir suas emissões, um meio suplementar de alcançar essas metas, introduzindo três mecanismos baseados no mercado e criando o que hoje é conhecido como "mercado de carbono".

Esses mecanismos de flexibilização adicionais de implementação, permitem que a redução das emissões e/ou o aumento na remoção de GEE sejam, em parte, obtidos além de suas fronteiras nacionais no cumprimento de suas metas. Tais mecanismos proporcionam um menor impacto nas economias e no nível de desenvolvimento dos países compromissados

Estes mecanismos adicionais incluem:

i. Implementação Conjunta (IC) - Joint Implementation - JI - onde uma Parte Anexo I pode transferir e/ou adquirir de qualquer outra Parte Anexo I as chamadas Unidades de Redução de Emissões UREs (ou Emission Reduction Unit - ERU), como forma de cumprimento parcial de suas metas de redução de GEE ou estas UREs podem ser transferidas parcialmente para o Segundo Período de Compromisso (entre 2013 e 2017) ${ }^{128}$.

ii. Comércio de Emissões (CE) - Emission Trade - ET - prevê que Partes Anexo I podem participar do comércio de emissões com outras Partes Anexo I, objetivando atender os compromissos quantificados de limitação e redução das emissões assumidas. A 
unidade aplicável aqui é a Unidade Quantificada Atribuída - UQA (ou Assigned Amount Unit - AAU). A UQA - é aplicada no âmbito do artigo 17 do Protocolo de Kyoto. Também expressa em toneladas métricas de $\mathrm{CO}_{2}$ equivalente, sendo uma unidade igual a uma tonelada de GEE. As UQAs podem ser transferidas parcialmente para o Segundo Período de Compromisso ${ }^{41,129}$.

iii. Mecanismo de Desenvolvimento Limpo - Clean Development Mechanism - (CDM) definido no artigo 12 do Protocolo de Kyoto e regulamentado pelo Acordo de Marrakech na COP 7 de 9/11/2001, dispõe sobre atividades de projetos de redução de emissão de GEE ou aumento de remoção de $\mathrm{CO}_{2}$, implantadas em Partes Não Anexo I e que irão gerar Reduções Certificadas de Emissões - RCEs, podendo ser utilizadas por Partes Anexo I como forma de cumprimento parcial de suas metas de redução de emissão de GEE As RCEs são aplicadas no âmbito do artigo 12 do Protocolo de Kyoto e expressa em toneladas métricas de $\mathrm{CO}_{2}$ equivalente, sendo uma unidade igual a uma tonelada de GEE ${ }^{14,78}$.

Dessa forma, ao permitir que as reduções de emissões de GEE sejam comercializadas globalmente, os mecanismos de flexibilização, e principalmente o Mecanismo de Desenvolvimento Limpo, tornaram-se um valioso atrativo econômico, colocando o setor privado como ator principal na busca de soluções para a questão das mudanças climáticas.

Além disto, a possibilidade de ganhos financeiros no mercado de carbono tem atraído a atenção de investidores que, objetivando lucrar com a comercialização futura das reduções certificadas, passam a formar fundos de investimento para projetos de MDL.

Nesse sentido, a abordagem do MDL é especificamente importante ao Brasil uma vez que, apesar de o país hospedar o terceiro maior número de atividades de projeto de MDL, com um total de 340 projetos registrados na Organização das Nações Unidas, em janeiro de 2009, sua regulamentação e as conseqüências de sua implantação são, ainda, praticamente desconhecidas pela sociedade brasileira e pelas organizações em geral ${ }^{68,168,174,175}$. 


\section{4. 2. Mecanismo de Desenvolvimento Limpo - MDL $113,130,131,132,133$}

Estabelecido no artigo 12 do Protocolo de Kyoto, os projetos MDL serão implantados em Países Não Anexo I, e só serão elegíveis se promoverem o desenvolvimento sustentável, expressão criada em 1987 e definida como:

"desenvolvimento que satisfaz as necessidades do presente sem comprometer a capacidade das futuras gerações de satisfazer as suas próprias necessidades" ${ }^{134}$.

Este importante pensamento agrega as categorias econômicas, sociais e ecológicas no país anfitrião que abrigará o projeto. O destaque dado ao desenvolvimento sustentável interliga a mitigação dos GEE com outros objetivos, tais como desenvolvimento econômico e social, redução de pobreza e da miséria, e é o único, dentre os mecanismos de flexibilização, que prevê a participação das nações em desenvolvimento ${ }^{113,130,132,133}$.

Dessa forma, os Países Anexo I estabelecerão em seus territórios metas para redução de $\mathrm{CO}_{2}$ junto aos seus principais emissores. Aqueles que não conseguirem (ou não desejarem) reduzir suas emissões poderão comprar RCE's, através da implantação de um MDL em países em desenvolvimento e usar esses créditos para cumprir suas obrigações.

Cria-se assim um mercado mundial de Reduções Certificadas de Emissão (RCE), gerados em projetos MDL, em especial por projetos de seqüestro de carbono, deixando claro que este mercado de carbono já é uma realidade, apesar de encontrar-se em estágio inicial de formação ${ }^{33}$.

O objetivo final de mitigação de GEE será atingido através da implementação de projetos que resultem na redução da emissão de gases de efeito estufa ou no aumento da remoção de gás carbônico, mediante, por exemplo, a substituição de fontes de energia fósseis por renováveis, a racionalização do uso da energia, o florestamento e reflorestamento, em investimentos de tecnologias mais eficientes e limpas, entre outros.

O conceito de tecnologia limpa foi desenvolvido pelo Programa das Nações Unidas para o Meio Ambiente (PNUMA), significando aplicar, de forma continuada, uma estratégia ambiental aos processos e produtos de uma indústria, com o objetivo de reduzir riscos ao meio ambiente e ao ser humano ${ }^{134}$. 


\section{4. 3. Artigos $M D L$ e sua aplicação no mercado ${ }^{118,135}$}

Os seguintes artigos do Protocolo de Kyoto contemplam as diferentes normas que devem ser seguidas pelas partes envolvidas em projetos de MDL.

i. $\quad$ Artigo 12.2 - O objetivo do Mecanismo de Desenvolvimento Limpo deve ser assistir às partes não incluídas no Anexo I para que atinjam o desenvolvimento sustentável e contribuam para o objetivo final da Convenção e, assistir às Partes incluídas no Anexo I para que cumpram seus compromissos quantificados de limitação e redução de emissões, assumidos no Artigo 3.

ii. Artigo 12.3 - Sob o Mecanismo de Desenvolvimento Limpo:

(a) as Partes não incluídas no Anexo I beneficiar-se-ão de atividades de projetos que resultem em reduções certificadas de emissões;

(b) as Partes incluídas no Anexo I podem utilizar as reduções certificadas de emissões resultantes de tais atividades de projetos, para contribuir com o cumprimento de parte de seus compromissos quantificados de limitação e redução de emissões, assumidos no Artigo 3, como determinado pela Conferência das Partes na qualidade de reunião das Partes deste Protocolo.

Podem, então, participar de um projeto de MDL aqueles países chamados Partes Anexo I, Partes Não Anexo I ou entidades públicas e privadas dessas Partes, desde que por elas devidamente autorizadas e estas atividades podem ser implementadas por meio de parcerias com o setor público ou privado.

Para que sejam consideradas elegíveis, no âmbito do MDL, esses projetos devem observar critérios fundamentais, entre os quais o da adicionalidade, onde uma atividade de projeto deve, comprovadamente, resultar na redução de emissões de GEE e/ou remoção de $\mathrm{CO}_{2}$, adicional ao que ocorreria na ausência da atividade de projeto do MDL.

iii. Artigo 12.4 - O Mecanismo de Desenvolvimento Limpo deve sujeitar-se à autoridade e orientação da Conferência das Partes na 
qualidade de reunião das Partes deste Protocolo e à supervisão de um conselho executivo do Mecanismo de Desenvolvimento Limpo

O Conselho Executivo unirá os interesses legítimos das Partes, sendo composto de forma equilibrada por Partes incluídas e também por Partes não incluídas no Anexo I. As funções do Conselho Executivo devem abranger:

(a) promoção e transparência de mercado;

(b) responsabilidade final pela certificação e verificação das reduções;

(c) registro e validação das agências de certificação.

A certificação de projetos propriamente dita deve ser atribuída a instituições que estejam trabalhando diretamente sob a direção e supervisão rigorosa do Conselho Executivo; deve haver um processo regulatório e de auditoria forte, ser transparente e com credibilidade.

iv. Artigo 12.5 - As reduções de emissões resultantes de cada atividade de projeto devem ser certificadas por entidades operacionais a serem designadas pela Conferência das Partes na qualidade de reunião das Partes deste Protocolo, com base em:

(a) participação voluntária de cada Parte envolvida;

(b) benefícios reais, mensuráveis e de longo prazo relacionados com a mitigação da mudança do clima;

(c) reduções de emissões que sejam adicionais as que ocorreriam na ausência da atividade certificada do projeto.

v. Artigo 12.6 - O Mecanismo de Desenvolvimento Limpo deve prestar assistência quanto à obtenção de fundos para atividades certificadas de projetos quando necessário.

vi. Artigo 12.7 - A Conferência das Partes na qualidade de reunião das Partes deste Protocolo deve, em sua primeira sessão, elaborar modalidades e procedimentos com o objetivo de assegurar transparência, eficiência e prestação de contas das atividades de projetos por meio de auditorias e verificações independentes. 
vii. Artigo 12.10 - Reduções certificadas de emissões obtidas durante $o$ período do ano 2000 até o início do primeiro período de compromisso, poderão ser utilizadas para auxiliar no cumprimento das responsabilidades relativas ao primeiro período de compromisso

As Reduções Certificadas de Emissões, (RCEs), são medidas em toneladas métricas de dióxido de carbono equivalente e representam os créditos que podem ser utilizados pelas Partes Anexo I - que tenham ratificado o Protocolo de Kyoto - como forma de cumprimento parcial de suas metas de redução de emissão de GEE.

As Partes Anexo I que possuem compromissos e metas de redução, deverão ser, obrigatoriamente, os principais participantes, pelo lado da demanda, desse mercado, e as Partes Não Anexo I terão um papel significativo em todo o processo.

Já as vantagens para um participante estrangeiro traduzem-se na possibilidade de cumprimento parcial de suas metas de redução a um custo marginal relativamente mais baixo.

Para os países em desenvolvimento, como o Brasil, o estímulo advindo dessas transações se concentrarão em projetos elegíveis no âmbito do MDL.

Espera-se que boa parte do investimento destinado às atividades de projeto do MDL venha do exterior, fomentando o investimento externo direto.

Quanto à destinação das RCEs, as Partes Anexo I podem demandá-las para o cumprimento de suas metas de redução atuais ou futuras.

Os participantes podem objetivar a comercialização ou revenda das RCEs na expectativa de uma valorização futura e realização de lucros, em função da demanda por Partes que possuem compromissos de redução de emissões.

As Organizações Não Governamentais (ONGs) podem adquirir RCEs sem objetivo de revenda, retirando-as simplesmente do mercado, com fins estritamente ambientais.

Na FIG. 9 é mostrado um diagrama que ilustra o exposto ${ }^{126}$. 


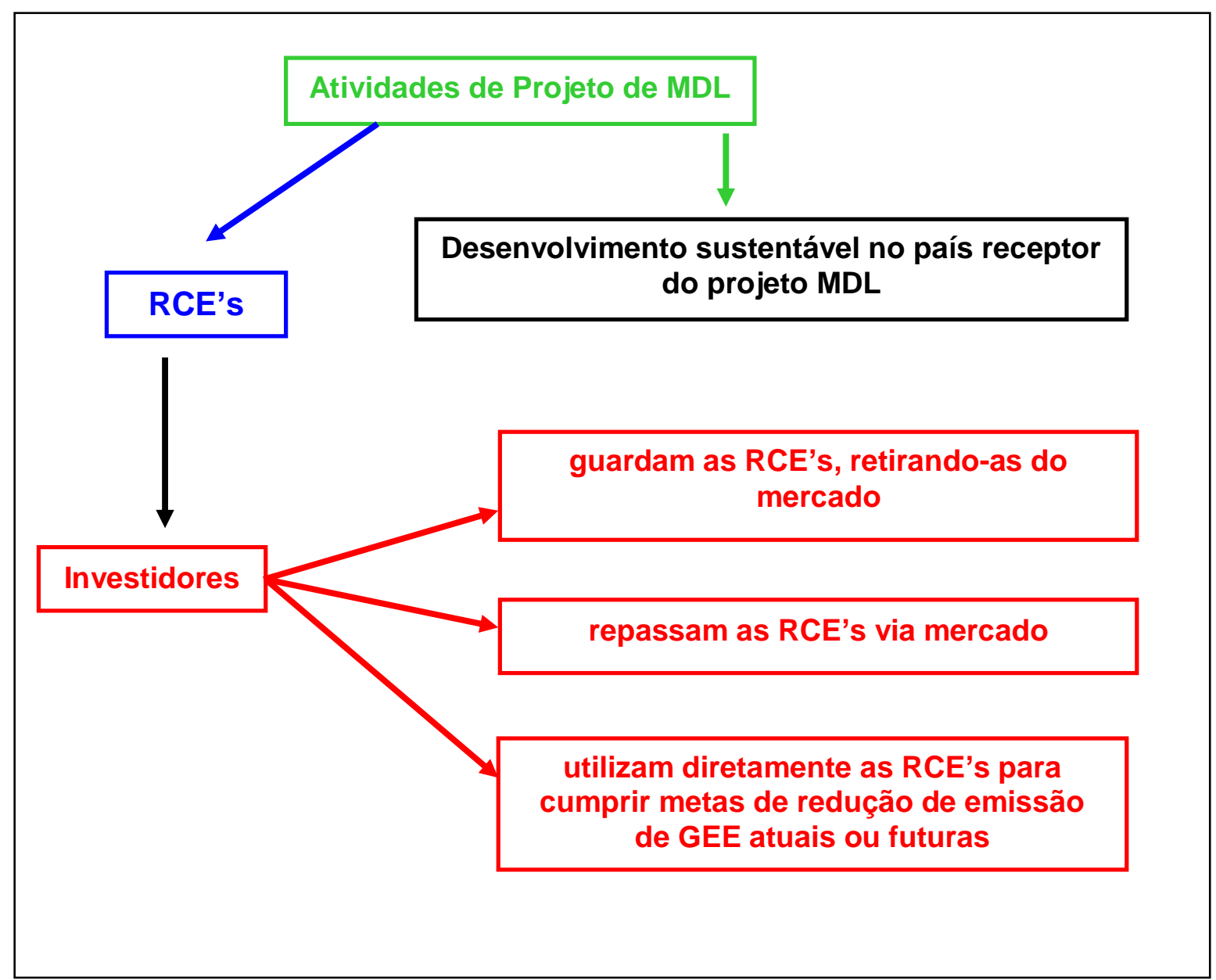

FIGURA 9 - Visão geral para a aplicação de um MDL e o destino que as RCE's podem ter ${ }^{126}$.

\section{4. 4. Locais de projetos MDL no mundo ${ }^{136}$}

O mapa interativo é um sistema de informação para o MDL e mostra a localização das atividades de MDL em todo o mundo.

Pelo mapa que é apresentado na FIG. 10, pode-se conhecer, de forma abrangente, cada local que hospeda um MDL, atualizado em setembro de 2009. 


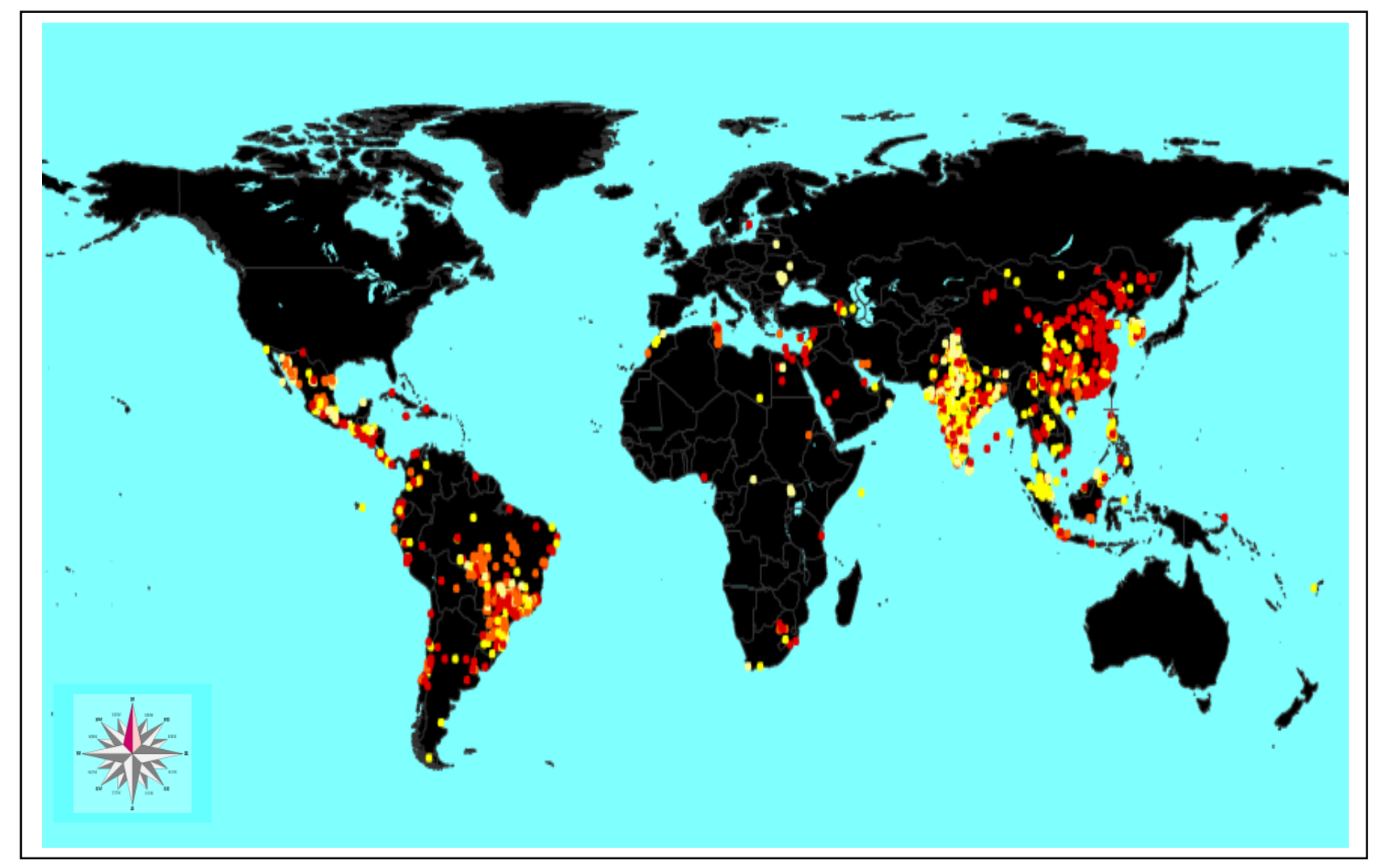

FIGURA 10 - Mapa interativo de projetos MDL desenvolvidos no mundo, na data de 04/09/2009, às 04h40 am, hora oficial de Brasília.

Legenda: (1) As fronteiras e os nomes mostrados e as designações utilizadas neste mapa não implicam endosso ou aceitação oficial pela ONU.

(2) De acordo com as cores presentes no mapa, temos:

- Projeto de MDL, em grande escala, uma localização

- Projeto de MDL, em larga escala, vários locais

- Projeto de MDL, em pequena escala, uma localização

- Projeto de MDL, em pequena escala, vários locais

\section{4. 5. Um exemplo de MDL no Brasil - Nova Gerar $137,138,139,140,141,142,143,144$}

O primeiro projeto de MDL, aprovado pela ONU, no mundo, foi o do aterro sanitário de Nova Iguaçu, mostrado na FIG. $11^{138}$, no Rio de Janeiro, em 19/11/2004, desenvolvido na Central de Tratamento de Resíduos Nova Iguaçu, realizando a recuperação ambiental e a captação do biogás do extinto Lixão da Marambaia. 
Esse projeto atraiu o interesse do Governo da Holanda por intermédio do Banco Mundial (BIRD), que fechou contrato com a empresa para a compra dos créditos de carbono gerados até 2012.

O projeto Nova Gerar usa a metodologia através da captação do biogás (ou gás de aterro) para geração de energia limpa. Este gás é produzido pela decomposição da matéria orgânica presente no lixo, e é composto em sua maior parte por $\mathrm{CH}_{4}$ vinte e uma vezes mais agressivo do que o $\mathrm{CO}_{2}$.

O projeto dispõe de um sistema de coleta de gás que é levado até plantas de geração de eletricidade, com potencial para gerar $12 \mathrm{MW}$, o suficiente para abastecer um município de um milhão de habitantes.

O seu faturamento, obtido com a venda de créditos de carbono, foi de $R \$$ 27 milhões em 2006 e deverá chegar a $\mathrm{R} \$ 35$ milhões em 2008, com projeção de redução, em 21 anos, de aproximadamente 15 milhões de toneladas de emissões de $\mathrm{CO}_{2}$ eq.

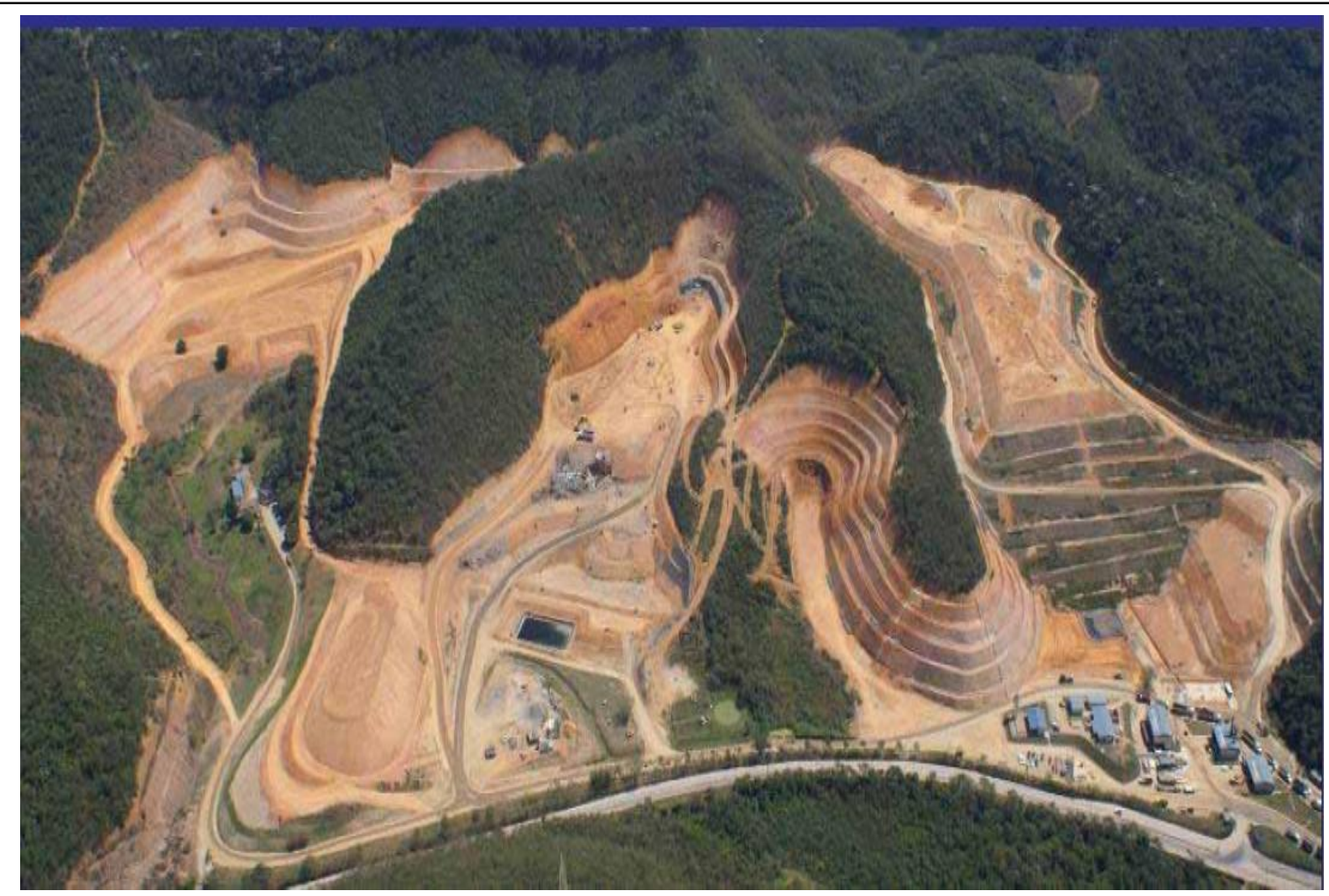

FIGURA 11 - Foto aérea do CTR (Central Total de Resíduos) em Nova Iguaçu. 


\section{5. Estrutura Institucional de um MDL 16,82,117,118,126,145,146,147}

O Protocolo de Kyoto estabelece que as atividades de projeto do MDL bem como as reduções de emissões GEE e/ou aumento de remoção de $\mathrm{CO}_{2}$ a estas atribuídas, serão submetidas a uma estrutura institucional, e a um conjunto de procedimentos para aferição, verificação e certificação das atividades de projeto. Dentre as instituições relacionadas ao MDL destacam-se:

\section{5. 1. Conselho Executivo do MDL}

O Conselho Executivo tem a função de supervisionar o funcionamento do MDL. Entre suas responsabilidades destacam-se:

i. o credenciamento das Entidades Operacionais Designadas (EOD);

ii. registro das atividades de projeto do $\mathrm{MDL}$;

iii. emissão das RCEs;

iv. desenvolvimento e operação do Registro do MDL e,

v. estabelecimento e aperfeiçoamento de metodologias para definição da linha de base, monitoramento e fugas.

\section{5. 2. Autoridade Nacional Designada - AND}

Os governos das Partes Não Anexo I devem designar, junto à CQNMUC, uma Autoridade Nacional para o MDL. A AND atesta que a participação dos países é voluntária e, no caso do país onde são implementados os projetos, que essas atividades contribuem para o desenvolvimento sustentável do país, a quem cabe decidir, de forma soberana, se este objetivo do MDL está sendo cumprido.

Além disso, a AND deve aprovar as atividades de projeto MDL antes de seu encaminhamento ao Conselho Executivo.

\section{5. 3. Autoridade Nacional Designada no Brasil}

A Autoridade Nacional Designada - AND no Brasil é a Comissão Interministerial de Mudança Global do Clima - CIMGC, estabelecida por Decreto Presidencial em 07 de julho de $1999{ }^{148}$.

Suas atribuições envolvem: ${ }^{149}$ 
i. emitir parecer, sempre que demandado, sobre as propostas de políticas setoriais, os instrumentos legais $e$ as normas que contenham aqueles componentes relevantes para a mitigação da mudança global do clima e para a adaptação do país aos seus efeitos;

ii. fornecer subsídios às posições do governo nas negociações sob a égide da CQNUMC e instrumentos subsidiários de que o Brasil seja parte;

iii. realizar a articulação com as entidades representativas da sociedade civil, no sentido de promover e permitir que as ações dos órgãos governamentais e também dos órgãos privados, em cumprimento às obrigações assumidas pelo Brasil perante a CQNUMC e aos instrumentos subsidiários dos quais o Brasil seja parte e como tal deve estar em compromisso nesse cumprimento.

iv. definir critérios de elegibilidade adicionais àqueles considerados pelos organismos da CQNUMC, encarregados do MDL, conforme as estratégias nacionais de desenvolvimento sustentável;

v. apreciar pareceres sobre projetos que resultem em reduções de emissões e que sejam considerados elegíveis para o MDL, e aprová-lo, se for o caso.

A CIMGC é presidida pelo Ministério da Ciência e Tecnologia e vicepresidida pelo Ministério do Meio Ambiente. É composta ainda por representantes dos Ministérios das Relações Exteriores; da Agricultura, Pecuária e Abastecimento; dos Transportes; das Minas e Energia; do Planejamento, Orçamento e Gestão; do Desenvolvimento, Indústria e Comércio Exterior e da Casa Civil da Presidência da República.

A secretaria executiva da Comissão é desempenhada pelo Ministério da Ciência e Tecnologia. Note-se que há representantes de todos os setores de atividades descritos no Anexo A do Protocolo de Kyoto, que classifica os setores de atividades e as categorias de fontes de emissão de gases de efeito estufa. 


\section{5. 4. Entidades Operacionais Designadas - EODs ${ }^{78,150}$}

São entidades nacionais ou internacionais credenciadas pelo Conselho Executivo e designadas pela COP/MOP, a qual ratificará ou não o credenciamento feito pelo Conselho Executivo.

As responsabilidades das Entidades Operacionais Designadas consistem em:

i. validar atividades de projetos do MDL de acordo com as decisões de Marrakech;

ii. verificar e certificar reduções de emissões de gases de efeito estufa e remoções de $\mathrm{CO}_{2}$;

iii. manter uma lista pública de atividades de projetos do MDL;

iv. enviar um relatório anual ao Conselho Executivo;

v. manter disponíveis para o público as informações sobre as atividades de projeto do MDL, que não sejam consideradas confidenciais pelos participantes do projeto.

Na FIG. 12 é mostrado, por meio de um diagrama que ilustra o exposto até o momento ${ }^{78}$.

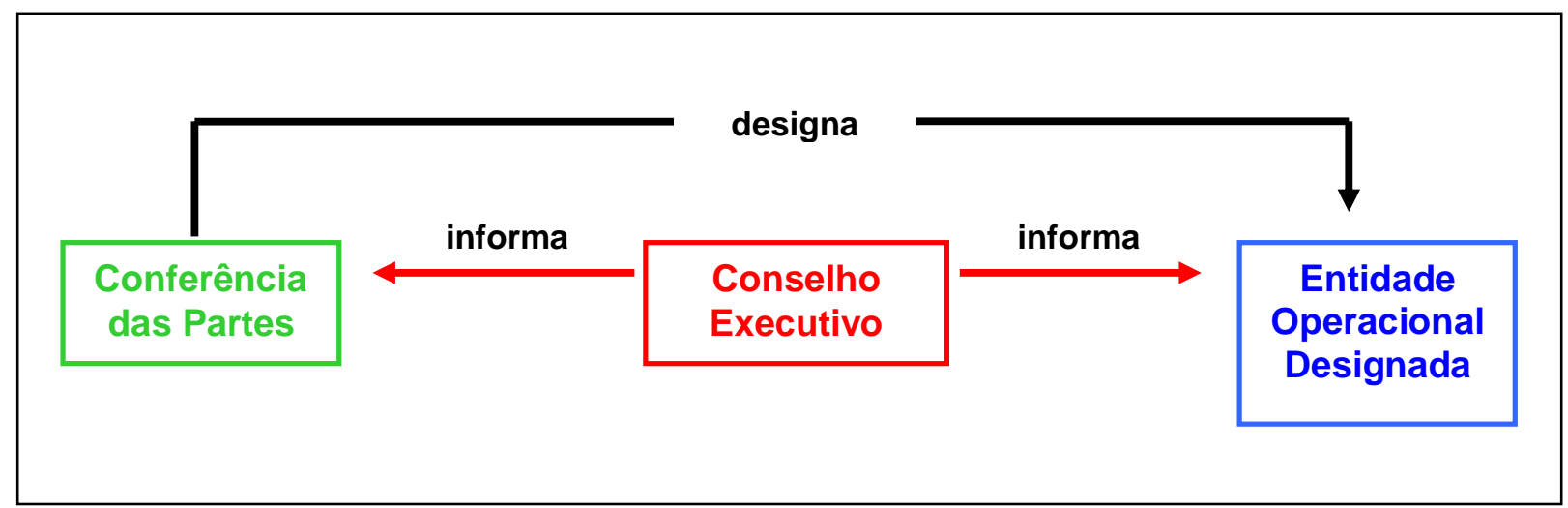

FIGURA 12 - Estrutura institucional relacionada ao MDL 


\section{5. 5. Elegibilidade de um MDL 112,145}

Para ser considerado elegível, isto é, ser efetivamente uma atividade de projeto de MDL de redução de emissões de GEE, o projeto deve atender fundamentalmente aos seguintes requisitos:

i. contar com a participação seja voluntária e aprovada pelas Partes envolvidas;

ii. contar com a aprovação do país hospedeiro do projeto (onde essas atividades forem implementadas);

iii. atingir os objetivos de desenvolvimento sustentável definidos pelo país hospedeiro onde as atividades de projeto forem implementadas;

iv. reduzir as emissões de gases de efeito estufa de forma adicional ao que ocorreria na ausência da atividade de projeto do MDL;

v. contabilizar o aumento de emissões de gases de efeito estufa que ocorram fora dos limites das atividades de projeto e que sejam mensuráveis e atribuíveis a essas atividades;

vi. levar em consideração a opinião de todos os atores que são o público, incluindo os indivíduos, os grupos e as comunidades afetadas ou com possibilidade de ser afetadas pela atividade de projeto do MDL, e que sofrerão os impactos das atividades de projeto e que deverão ser consultados a esse respeito;

vii. não causar impactos colaterais negativos ao meio ambiente local;

viii. proporcionar benefícios mensuráveis, reais e de longo prazo relacionados com a mitigação da mudança do clima;

ix. relacionar-se aos GEE e setores definidos no Anexo A do Protocolo de Kyoto ou se refiram às atividades de projetos de reflorestamento e florestamento. No âmbito do MDL, as definições de reflorestamento e de florestamento para o primeiro período de compromisso deverão considerar as questões de não-permanência, adicionalidade, fuga, incertezas e impactos sócio-econômicos e ambientais, além dos impactos na biodiversidade e ecossistemas. Decisões sobre essas definições e modalidades fizeram parte da pauta da Nona Sessão da Conferência das Partes - COP-9, realizada no final do ano de 2003. 


\section{5. 6. $\mathrm{O}$ Ciclo do Projeto MDL ${ }^{16,150}$}

A AND somente recebe para avaliação projetos que tenham sido previamente validados por uma Entidade Operacional Designada (EOD) reconhecida no País ${ }^{151}$.

Para que resultem em RCEs, as atividades de projeto do MDL devem, necessariamente, passar pelas etapas do Ciclo do Projeto, quais sejam:

i. elaboração do Documento de Concepção de Projeto, usando uma metodologia de linha de base e um plano de monitoramento aprovados;

ii. validação (verifica se o projeto está em conformidade com a regulamentação estabelecida e aprovada pelas partes do Protocolo de Kyoto);

iii. aprovação pela Autoridade Nacional Designada, que, no caso do Brasil, é a Comissão Interministerial de Mudança Global do Clima (verifica a contribuição do projeto para o desenvolvimento sustentável no país anfitrião e confirma a participação voluntária);

iv. submissão ao Conselho Executivo para registro;

v. monitoramento;

vi. verificação/certificação;

vii. emissão e distribuição de RCE conforme acordado entre as partes do projeto no DCP.

\section{5. 7. Documento de Concepção do Projeto - DCP 146,152,153,154,155}

O Documento de Concepção do Projeto é o documento principal para fins de aprovação da atividade de projeto no MDL e sua elaboração é de responsabilidade dos proponentes do projeto. Deve utilizar uma metodologia e um plano de monitoramento aprovados pelo Comitê Executivo e descrever detalhadamente as atividades a serem desenvolvidas no projeto.

A partir do DCP a entidade responsável pela validação do projeto vai avaliar se este satisfaz os requisitos do MDL. 
O DCP deverá incluir:

i. a descrição da atividade de projeto;

ii. a descrição dos participantes da atividade de projeto;

iii. a descrição da linha de base calculada a partir de uma metodologia aprovada;

iv. as metodologias para uma estimativa de cálculo da redução de emissões de gases de efeito;

v. a metodologia para o estabelecimento dos limites das atividades de projeto;

vi. a metodologia para o cálculo das fugas;

vii. a definição do período de obtenção de créditos;

viii. o plano de monitoramento, utilizando uma metodologia de monitoramento aprovada;

ix. a justificativa para adicionalidade da atividade de projeto;

x. um relatório de impactos ambientais;

xi. a definição do período de obtenção de créditos;

xii. os comentários dos atores;

xiii. informações quanto à utilização de fontes adicionais de financiamento;

xiv. apresentação dos resultados da consulta pública efetuada.

\section{5. 8. Linha de base $17,146,156,157,158.159$}

A linha de base de uma atividade de projeto do MDL é o cenário que representa, de forma razoável, as emissões antrópicas de GEE por fontes que ocorreriam na ausência da atividade de projeto proposta, incluindo as emissões de todos os gases, setores e categorias de fontes listadas no Anexo A do Protocolo de Kyoto que ocorram dentro do limite do projeto.

Serve de base tanto para verificação da adicionalidade como para a quantificação das RCEs das atividades de projeto. 
As RCEs serão calculadas justamente pela diferença entre as emissões da linha de base e as emissões verificadas em decorrência das atividades de projeto do MDL, incluindo as fugas.

A linha de base é qualificada e quantificada com base em um Cenário de Referência.

Para estabelecer a linha de base de atividade de projeto do MDL, os participantes devem adotar, entre as abordagens metodológicas abaixo listadas, a que for considerada mais apropriada para a atividade de projeto, levando em conta qualquer orientação do Conselho Executivo, e justificar a adequação de sua escolha quanto à (às): ${ }^{112}$

i. emissões status quo - emissões atuais ou históricas existentes, conforme o caso;

ii. condições de mercado - emissões de uma tecnologia reconhecida e economicamente atrativa, levando em conta as barreiras para 0 investimento;

iii. melhor tecnologia disponível - a média das emissões de atividades de projeto similares realizadas nos cinco anos anteriores à elaboração do documento de projeto, em circunstâncias sociais, econômicas, ambientais e tecnológicas similares, e cujo desempenho esteja entre os primeiros $20 \%$ (vinte por cento) de sua categoria.

Os participantes de uma atividade de projeto do MDL poderão, de forma alternativa, propor novas abordagens metodológicas, o que, no entanto, dependerá de aprovação pelo Conselho Executivo.

\section{5. 9. Cálculo de emissões da linha de base 104,131,158}

Dentro da mesma metodologia, o cálculo de emissões da linha de base deve conter a descrição das fórmulas utilizadas para calcular e projetar:

i. as emissões antrópicas de gases de efeito estufa da linha de base por fontes; 
ii. as fugas. O resultado desses cálculos representa as emissões da linha de base. Deve-se levar em consideração que uma tonelada de carbono equivale a 3.67 toneladas de $\mathrm{CO}_{2}$, o que significa dizer que uma tonelada de $\mathrm{CO}_{2}$ equivale a 0.273 toneladas de carbono.

\section{5. 10. Limite do projeto ${ }^{154,160}$}

O limite do projeto abrange todas as emissões de gases de efeito estufa, sob controle dos participantes das atividades de projeto que sejam significativas e atribuíveis, de forma razoável, a essas atividades.

\section{5. 11. Fuga 154,160}

A fuga corresponde ao aumento de emissões de gases de efeito estufa que ocorram fora do limite da atividade de projeto do MDL e que, ao mesmo tempo, sejam mensuráveis e atribuíveis à atividade de projeto.

A fuga é deduzida da quantidade total de RCEs obtidas pela atividade de projeto do MDL. Dessa forma, são considerados todos os possíveis impactos negativos em termos de emissão de gases de efeito estufa.

A diferença entre os resultados obtidos através dos cálculos dos Limite do Projeto e da Fuga, representará as reduções de emissões das atividades de projeto do MDL.

\section{5. 12. Adicionalidade $16,146,154,159,161,162$}

A partir da linha de base é determinada a adicionalidade da atividade de projeto de MDL, demonstrando a redução das emissões de GEE.

A adicionalidade é um critério fundamental para que uma determinada atividade de projeto seja elegível ao MDL. Consiste na redução das emissões dos GEE ou no aumento das remoções de $\mathrm{CO}_{2}$ de forma adicional ao o que ocorreria na ausência de tal atividade.

Para avaliar as emissões relativas às atividades de projeto do MDL, a metodologia de cálculo deve conter a descrição das fórmulas utilizadas para calcular: 
i. e estimar as emissões antrópicas de gases de efeito estufa da atividade de projeto do MDL, por fontes, dentro do limite do projeto;

ii. e projetar as fugas. O resultado desses cálculos representa as emissões da atividade de projeto do MDL.

Além disso, a adicionalidade deve demonstrar que o MDL propiciou a viabilidade econômico-financeira da atividade de projeto, ou seja, que ela não ocorreria sem o MDL ou que o projeto não teria acontecido naturalmente, mesmo sem o MDL.

Sob o ângulo da redução de emissões, em projetos de MDL, a adicionalidade dos benefícios está diretamente relacionada com a linha de base.

Na FIG. 13 é mostrado através de um exemplo gráfico, a suposição, em um projeto MDL, onde se quisesse substituir o uso de um combustível fóssil por uma fonte de em energia renovável (como biomassa), a emissão dessa fonte fóssil seria chamada de "X". Nesse caso, "X" é a linha de base. Com a instalação das atividades do projeto com energia renovável, a emissão passaria a ser "Y". A diferença entre as emissões "X-Y" se constitui na adicionalidade.

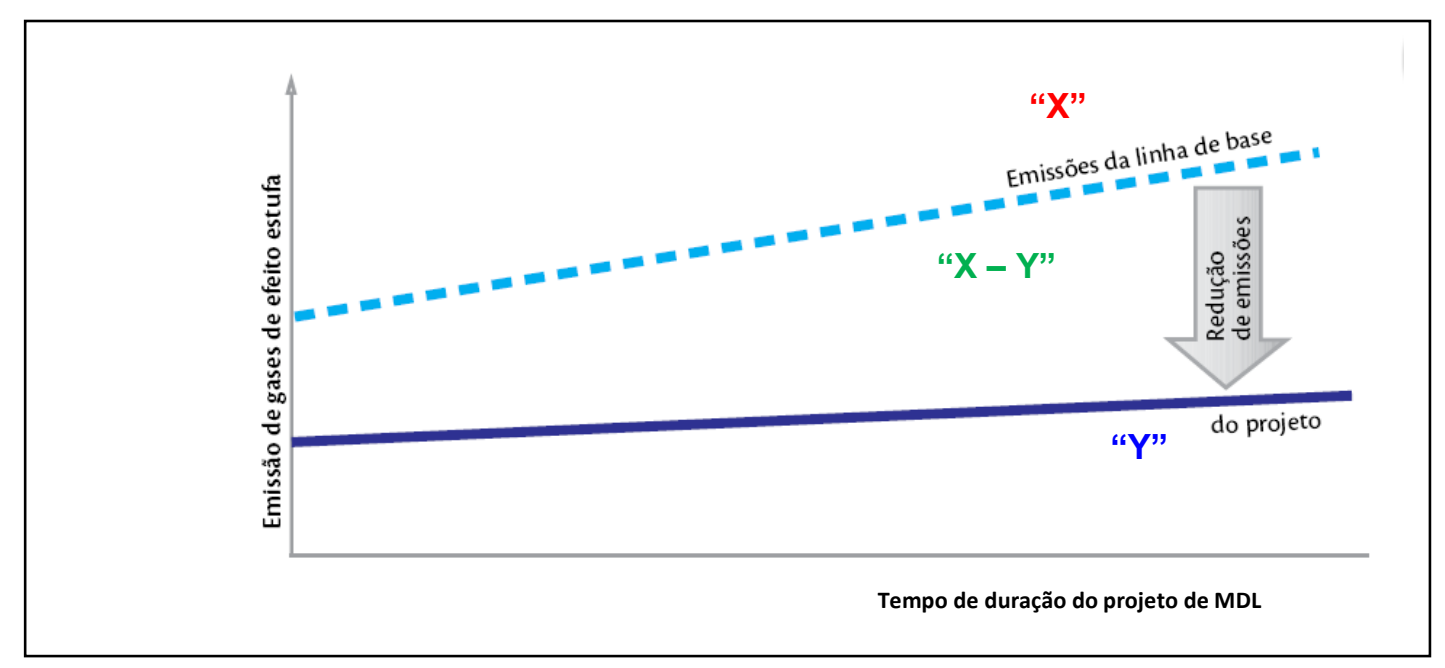

FIGURA 13 - Conceito gráfico de adicionalidade ${ }^{162}$. 


\section{5. 13. Monitoramento $154,162,163$}

É representada pela implementação de um Plano de Monitoramento (Monitoring Plan) registrado no PDD, conforme metodologia aprovada. O monitoramento é condição limitante para a verificação/certificação e emissão das RCE.

Corresponde a uma atividade de coleta e armazenamento de dados sobre o projeto que objetiva mensurar as emissões antrópicas de GEE. É desempenhada pelo proponente, e quaisquer revisões no plano de monitoramento devem ser justificadas e submetidas novamente para validação.

A consistência dos dados contidos no relatório de monitoramento deve ser verificada e certificada por uma entidade independente (Entidade Operacional Designada), para ser encaminhada ao Conselho Executivo, permitindo que as RCEs correspondentes possam ser emitidas.

O plano de monitoramento inclui a forma de coleta e armazenamento de todos os dados necessários para calcular a redução das emissões de gases de efeito estufa, de acordo com a metodologia de linha de base estabelecida no DCP, que tenham ocorrido dentro dos limites do projeto ou fora desses limites, desde que sejam atribuíveis à atividade de projeto e dentro do período de obtenção de créditos.

O período de obtenção de créditos pode ter duração máxima de sete anos, com duas renovações da linha de base, totalizando três períodos de sete anos, ou de dez anos, sem renovação, conforme o Artigo 3 da Resolução no 01 de 11 de setembro de 2003 da CIMGC ${ }^{163}$.

\section{5. 14. Documentos e referências sobre impactos ambientais}

Refere-se à documentação e às referências sobre os impactos causados pelas atividades de projetos considerados significativos pelos participantes da atividade de projeto, incluindo um relatório de impacto ambiental e o termo de referência da avaliação de impacto ambiental ${ }^{14,37,103}$. 


\section{5. 15. Comentários dos atores ${ }^{65}$}

Inclui o resumo dos comentários dos envolvidos direta e indiretamente nas atividades do projeto de MDL (os chamados atores).

Nesse resumo devem constar no relatório de que forma os comentários foram levados em consideração nas atividades do projeto do MDL.

\section{5. 16. Informações sobre fontes adicionais de financiamento ${ }^{25,164,165}$}

São informações sobre as fontes de financiamento públicas destinadas às atividades do projeto, evidenciando que o financiamento não resultou de desvio de Assistência Oficial ao Desenvolvimento - AOD e que é distinto e não é contado como parte das obrigações financeiras das Partes do Anexo I que participam da atividade de projeto.

\section{5. 17. Validação e Aprovação $112,113,145,154,162$}

A Validação consiste na avaliação do Documento de Concepção de Projeto (DCP) por uma empresa certificadora, acreditada pelas Nações Unidas, e é um pré-requisito para o registro na Convenção-Quadro das Nações Unidas sobre Mudança do Clima (UNFCCC).

A Entidade Operacional Designada (EOD) deve enviar seu relatório de validação, usando o "Formulário do relatório de registro e validação da atividade de projeto no âmbito do MDL" para solicitar o registro de uma atividade de projeto proposta.

Durante a Validação, a EOD analisará o DCP e atestará se ele está em conformidade às regras e normas do Comitê Executivo de MDL. Parte do processo de avaliação consiste na disponibilização do projeto para comentários públicos, através da página eletrônica da certificadora e das Nações Unidas.

Com base nesse documento, a EOP irá avaliar e validar a atividade de projeto do MDL proposta, checando se os seguintes pontos foram incluídos e considerados no DCP: 
i. se a atividade de projeto do MDL é voluntária e foi aprovada formalmente pela AND do país hospedeiro onde são implementadas as atividades de projeto;

ii. se a atividade de projeto do MDL atende aos critérios de elegibilidade;

iii. se há, de fato, a comprovação do crédito de adicionalidade, isto é, se há uma redução adicional nas emissões de GEE;

iv. se os comentários dos atores envolvidos foram incluídos e, obrigatoriamente, de alguma forma considerados;

v. se a análise de impacto ambiental foi realizada segundo a legislação ambiental nacional, se for o caso;

vi. se as emissões de gases de efeito estufa fora dos limites da atividade de projeto, porém atribuíveis a ela, ou seja, a fuga, foram consideradas;

vii. se a nova metodologia para a linha de base proposta - se for esse o caso - está de acordo com as modalidades e procedimentos para a proposição de novas metodologias;

viii. se o período de obtenção dos créditos foi definido.

No caso do Brasil, os projetos são analisados pelos integrantes da Comissão Interministerial de Mudança Global do Clima (CIMGC), que avaliam o relatório de validação e a contribuição da atividade de projeto para o desenvolvimento sustentável do país, segundo cinco critérios básicos: ${ }^{146,147,148}$

i. distribuição de renda;

ii. sustentabilidade ambiental local;

iii. desenvolvimento das condições de trabalho e geração líquida de emprego;

iv. capacitação e desenvolvimento tecnológico;

v. integração regional e articulação com outros setores.

A Aprovação pela Autoridade Nacional Designada se dará após a análise do projeto perante as regras e normas do Comitê Executivo de MDL, com ênfase 
nos critérios de sustentabilidade da atividade. A DNA Brasileira é representada pela CIMGC, que após a análise do projeto, emitirá a Carta de Aprovação

\section{5. 18. Registro pelo Conselho Executivo $112,113,145,152.154,162$}

O registro, que é a aceitação formal pelo Conselho Executivo da CQNUMC, é dado a um projeto validado como atividade de projeto de $M D L$, e é o passo subsequente à aprovação pela Autoridade Nacional Designada.

De acordo com o parágrafo de modalidades e procedimentos do MDL, a solicitação de registro de uma atividade de projeto deve ser feita na forma de um relatório de validação que contenha o documento de concepção do projeto, a aprovação por escrito da Parte anfitriã e uma explicação de como a Entidade Operacional Designada (EOD) levou devidamente em consideração os comentários do público recebidos sobre o PDD.

A aprovação pela CIMGC é necessária para a aceitação dos projetos, mas não é suficiente para seu registro no Conselho Executivo, que analisa também a metodologia escolhida e a adicionalidade do projeto, entre outros aspectos.

Seguindo-se uma Validação bem sucedida, a entidade operacional envia uma solicitação de registro do projeto ao Conselho Executivo do MDL, na forma de um Relatório de Validação juntando a carta de aprovação da Autoridade Nacional Designada (AND) presidida pelo MCT.

O registro é o pré-requisito para o monitoramento, a verificação/certificação e a emissão das Reduções Certificadas de Emissões (RCE's) relativas à atividade de projeto. O Conselho Executivo é o supervisor mundial do MDL.

\section{5. 19. Verificação / Certificação $25,66,126,146,161$}

A verificação/certificação é um processo de auditoria periódico e independente para revisar os cálculos relacionados à redução de emissões de GEE ou à remoção de $\mathrm{CO}_{2}$ resultantes de uma atividade de projeto do MDL.

Uma Entidade Operacional Designada - EOD deverá ser contratada para elaborar um Relatório de Verificação a ser encaminhado ao Conselho Executivo.

O objetivo dessa etapa é quantificar as reduções de emissões de gases que ocorreram como resultado da atividade de projeto do MDL, até a data da 
realização do Relatório. A EOD deverá certificar que a atividade de projeto atingiu de fato as reduções de emissões declaradas no período.

A certificação formal será baseada no relatório de verificação e será considerada definitiva 15 (quinze) dias após ter sido recebida pelo Conselho Executivo. Esta certificação garante que as reduções de emissões de gases de efeito estufa foram de fato adicionais às que ocorreriam na ausência da atividade de projeto. A declaração da certificação é enviada aos participantes da atividade de projeto, às Partes envolvidas e ao Conselho Executivo e, posteriormente, tornada pública.

Apenas as atividades de projetos do MDL validadas e registradas são verificadas e certificadas.

A EOD irá:

i. verificar as metodologias utilizadas;

ii. assegurar que a metodologia e documentação estão completas e, se necessário, recomendar correções;

iii. determinar as reduções de emissões de gases de efeito estufa;

iv. informar aos participantes das atividades de projeto quaisquer modificações necessárias;

v. providenciar o relatório de verificação para os participantes da atividade de projeto;

vi. fazer inspeções de campo;

vii. entrevistar os participantes do projeto e os atores locais;

viii. coletar dados e medições;

ix. observar práticas estabelecidas;

x. testar a acurácia do equipamento de monitoramento.

\section{5. 20. Emissão das RCE's ${ }^{6,25,66,112,146,161,162,166,167}$}

Essa etapa gerará um relatório quando o Conselho Executivo tem certeza de que, cumpridas todas as etapas, as reduções de emissões de GEE decorrentes das atividades de projeto são reais, mensuráveis e de longo prazo e, portanto, podem dar origem a RCE. 
As RCE's são emitidas pelo Conselho Executivo e creditadas aos participantes de uma atividade de projeto na proporção por eles definida e, dependendo do caso, podem ser utilizadas como forma de cumprimento parcial das metas de redução de emissão de GEE.

O relatório de certificação incluirá solicitação para que o Conselho Executivo emita um montante de RCEs correspondente ao total de emissões reduzidas obtidas pela atividade de projeto do MDL.

A emissão ocorrerá 15 (quinze) dias após o recebimento da solicitação, a menos que uma das Partes envolvidas na atividade de projeto ou pelo menos três membros do Conselho Executivo requisitem a revisão da emissão das RCEs.

Essa revisão deve limitar-se a questões de fraude, mau procedimento ou de incompetência da EOD. Nesse caso, o Conselho Executivo finalizará, em 30 (trinta) dias, a revisão.

O administrador do Registro do MDL, subordinado ao Conselho Executivo, deposita as RCEs certificadas nas contas abertas nesse mesmo Registro, de acordo com o solicitado no Documento de Concepção do Projeto, em nome das devidas Partes, bem como dos participantes das atividades de projeto do MDL, já deduzida a parcela equivalente a $2 \%$ (dois por cento) do total das RCEs, integrará um fundo de adaptação, destinado a ajudar os países mais vulneráveis a se adaptarem aos efeitos adversos da mudança do clima.

Outra parcela, determinada pela COP, por recomendação do Conselho Executivo, será utilizada para cobrir despesas administrativas do MDL.

Esse ciclo é teoricamente infinito e se repetirá na frequência em que o proponente do projeto quiser fazer jus às RCE a que tem direito.

Dessa forma, o Ciclo de Verificação/Ciclo de Emissão de RCEs ocorrerá quando o proponente de projeto contratar uma EOD para elaborar o relatório de verificação, quantificando e certificando as reduções de emissões alcançadas pelo projeto naquele dado período, e requisitar ao Conselho Executivo do MDL a emissão das RCE a que o projeto tem direito.

Na FIG. 14 é mostrado, de forma simplificada, o exposto acima ${ }^{162}$. 


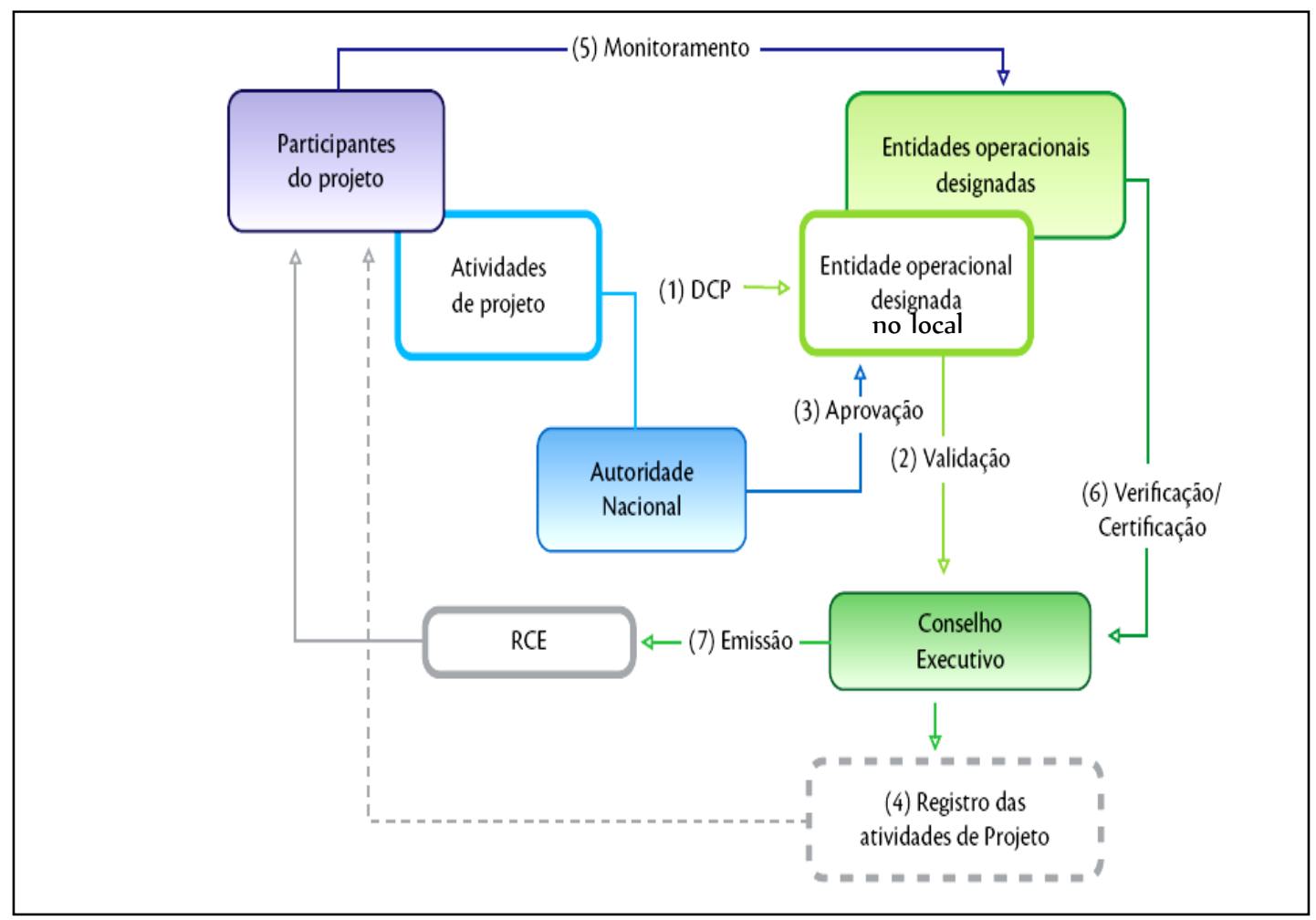

FIGURA 14 - Visão geral das etapas desenvolvidas num projeto MDL e a aquisição das RCEs ${ }^{162}$.

\section{6. Distribuição das atividades de projeto ${ }^{147,162,168,169}$}

Segundo os Acordos de Marrakech, as atividades de projeto estão divididas em projetos de grande escala ou de pequena escala.

\section{6. 1. Projetos MDL de grande (ou larga) escala ${ }^{162,169}$}

Os projetos de atividade de MDL de grande escala, caracterizam-se pelo fato de não haver limites para sua extensão e em poder ter esse limite fragmentado entre inúmeras atividades, unidas em um único projeto de MDL.

Não há limites para o número ou tamanho das atividades produtivas que se pretende unir em uma única atividade de projeto de MDL. Sua validação e a verificação, necessariamente, serão realizadas por EOD's distintas, sem exceção. 
O objetivo desse procedimento é o de detectar eventuais falhas ou erros não observados pelas EODs contratadas.

As metodologias para atividades de MDL de grande escala são mais conservadoras e bastante restritivas.

Assim, aspectos como fugas, transporte de matéria-prima, emissões durante a fase de construção, emissões decorrentes da disposição de resíduos, calibração de equipamentos e registro de informações são tratados em maior detalhe.

\section{6. 2. Projetos MDL de pequena escala 94,145,162,164}

Conceitualmente, um projeto de MDL de pequena escala assemelha-se a um de grande escala, mas com limitação de tamanho estabelecida em sua metodologia e restrição quanto à subdivisão de sua atividade em várias de pequena escala.

As metodologias de pequena escala são desenvolvidas pelo Conselho Executivo e disponibilizadas ao público e caso sejam autorizadas podem ser validadas e monitoradas por uma mesma EOD.

Projetos de pequena escala surgiram a partir da percepção de que os custos de procedimento envolvidos no desenvolvimento de um MDL de grande escala inviabilizariam sua aplicação em uma série de empresas de menor porte.

Assim, visando reduzir os custos transacionais, alguns procedimentos foram simplificados, criando os seguintes tipos de projetos:

i. atividades de projeto de energia renovável com capacidade máxima de produção equivalente a até $15 \mathrm{MW}$ (ou uma equivalência adequada);

ii. atividades de projeto de melhoria da eficiência energética que reduzam o consumo de energia no lado da oferta e/ou da demanda, em até no máximo de 60 GWh por ano (ou um equivalente adequado); 
iii. outras atividades de projeto que tanto reduzam emissões antrópicas por fontes quanto emitam diretamente menos do que 60 quilotoneladas equivalentes de dióxido de carbono por ano.

Na TAB. 12 exemplifica-se o exposto sobre os dois tipos de MDL ${ }^{162}$.

TABELA 12 - Principais diferenças entre o MDL de pequena e grande escala

\begin{tabular}{|c|c|c|}
\hline & $\begin{array}{c}\text { MDL de pequena } \\
\text { escala }\end{array}$ & $\begin{array}{c}\text { MDL de grande } \\
\text { escala }\end{array}$ \\
\hline Tamanho & Há limitação & Não há limitação \\
\hline Metodologias & $\begin{array}{l}\text { Elaboradas pelo } \\
\text { CQNUMC }\end{array}$ & $\begin{array}{l}\text { Elaboradas pelos } \\
\text { proponentes do projeto }\end{array}$ \\
\hline Desagrupamento & $\begin{array}{l}\text { Pode ser autorizado } \\
\text { pelo Conselho } \\
\text { Executivo }\end{array}$ & Não são permitidos \\
\hline $\begin{array}{l}\text { Validação e } \\
\text { verificacãa }\end{array}$ & $\begin{array}{l}\text { Pode ser autorizado } \\
\text { por uma única EOD }\end{array}$ & EODs diferentes \\
\hline
\end{tabular}

Dentro do Brasil, o que se observa é a predominância de projetos de grande escala, correspondendo a $55 \%$ do total das atividades desenvolvidas no país. Na FIG. 15 é mostrado um diagrama que busca explicar o exposto. 


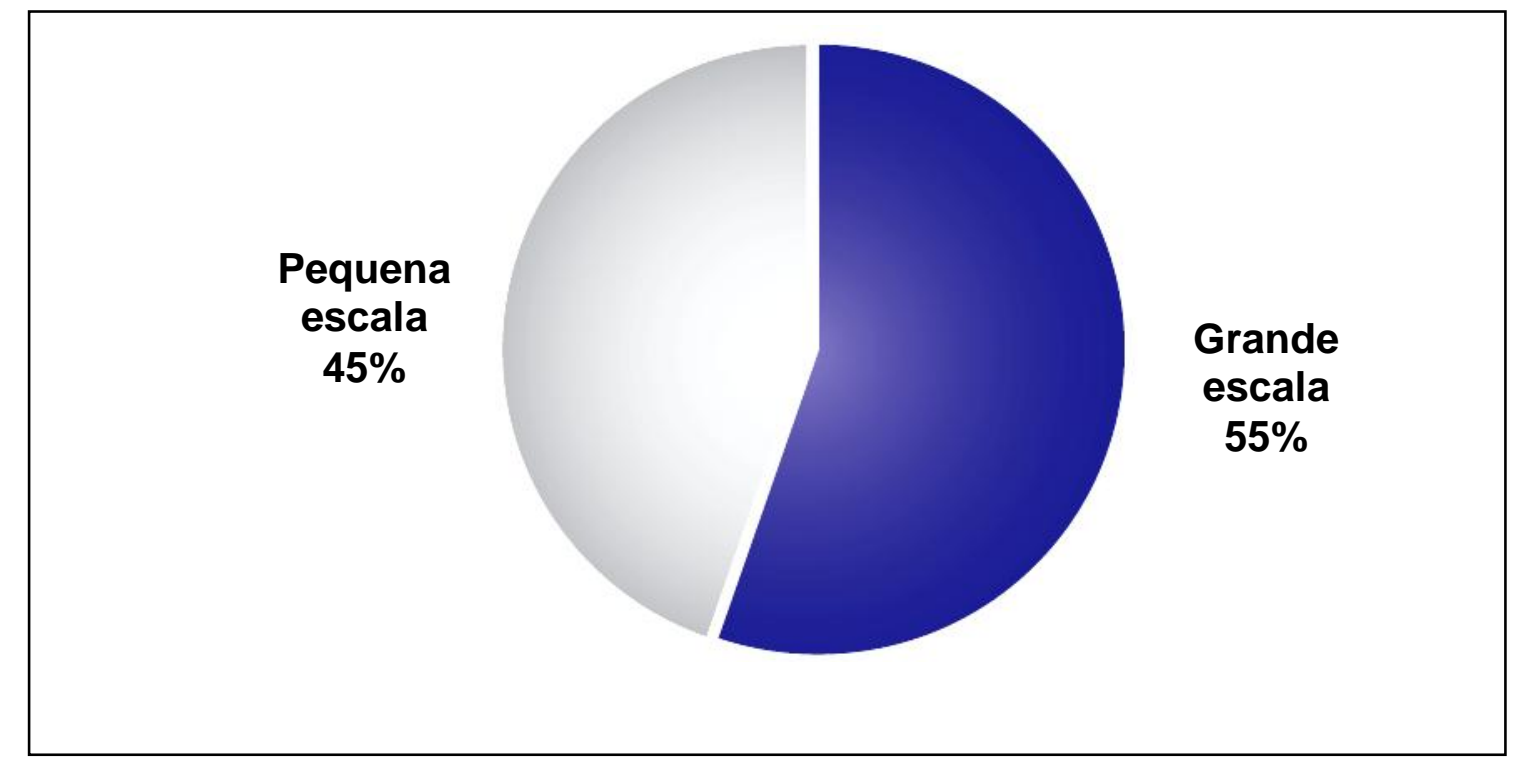

FIGURA 15 - Composição do cenário nacional de projetos de MDL de grande e pequena escala ${ }^{162}$.

No âmbito da proposta para um MDL, o ciclo de projetos é o mesmo, seja ele de pequena ou de grande escala.

Na FIG. 16 são mostrados os principais passos de cada etapa do ciclo de um projeto de Mecanismo de Desenvolvimento Limpo (MDL), bem como uma explicação sucinta das mesmas ${ }^{170}$. 


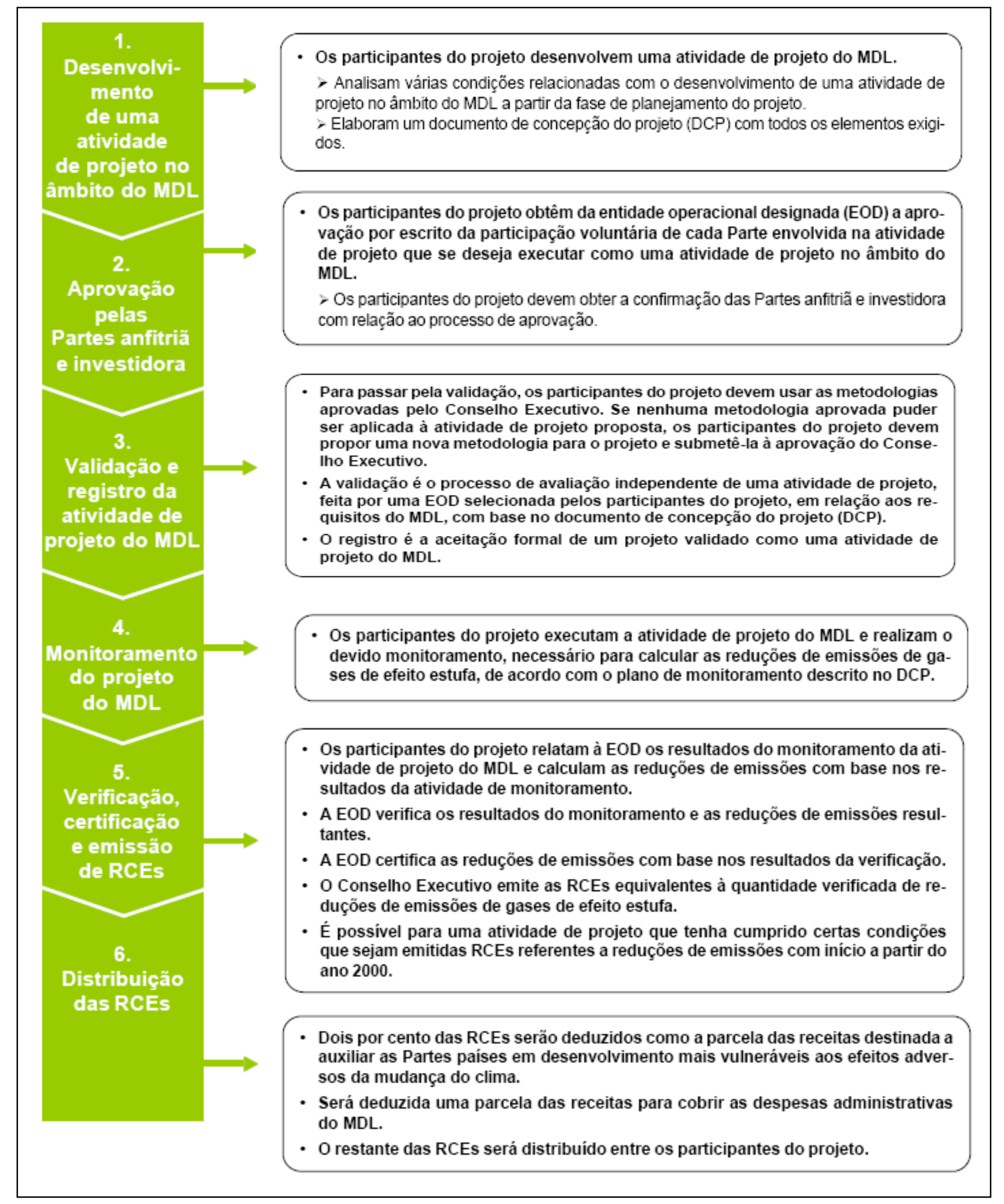

FIGURA 16 - Ciclo do projeto de MDL ${ }^{162,167,173 .}$ 


\section{7. Panorama mundial e brasileiro de projetos MDL e RCE's}

Neste item serão apresentados os resultados alcançados no desenvolvimento de projetos de MDL no Brasil e no mundo, com um enfoque maior nas informações nacionais.

\section{7. 1. Panorama no ano de 2008}

Até fevereiro de 2008 havia um total de 2.999 projetos que encontravam-se em alguma fase do ciclo de projetos de MDL.

Destes, 879 já estavam registrados pelo Conselho Executivo do MDL e 2.120 em alguma das outras etapas do ciclo ${ }^{167}$.

O Brasil, nesse cenário, ocupava o terceiro lugar em número de atividades de projeto, estando elencado com 268 deles, cerca de $9 \%$ do total.

Já, em primeiro lugar estava a Índia, com 1.010 projetos, cerca de 34\% do total, e, em segundo lugar, estava a China, com 845 projetos, cerca de $28 \%$ do total, como é mostrado no diagrama da FIG. $17^{162}$.

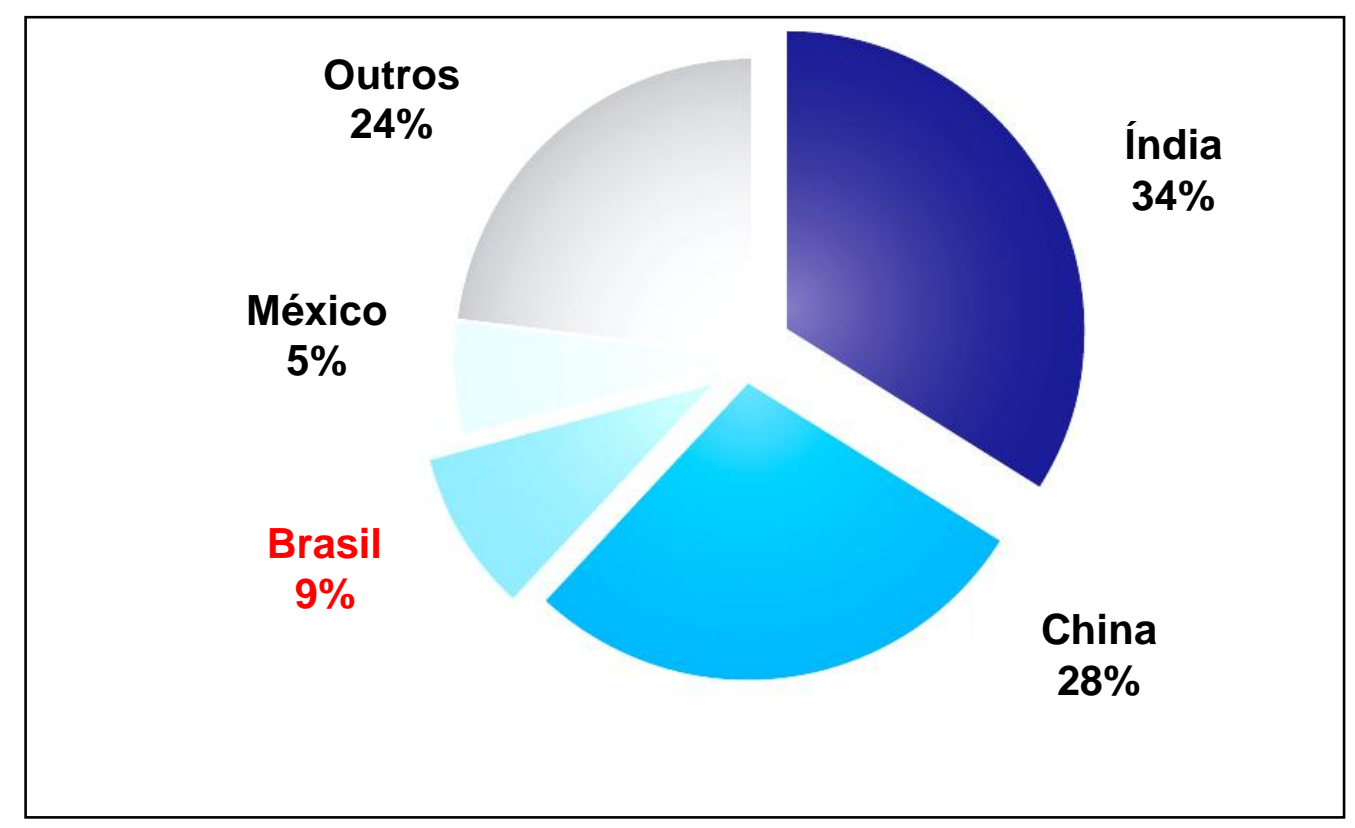

FIGURA 17 - Distribuição relativa mundial de projetos MDL em $2008{ }^{162}$. 
Na FIG. 18 é, mostrado, de modo claro, a presença marcante da biomassa na capacidade total instalada das atividades de projeto no âmbito do MDL aprovadas pelo CIMGG, na área energética.

$\mathrm{Na}$ distribuição dessas áreas energéticas, nota-se que a primeira posição é ocupada pela biomassa, com 1409,5 MW, a segunda posição corresponde às hidrelétricas, com $800 \mathrm{MW}$ e a terceira posição é ocupada pelas pequenas centrais hidrelétricas, com 542,5 MW ${ }^{171,172,173}$.

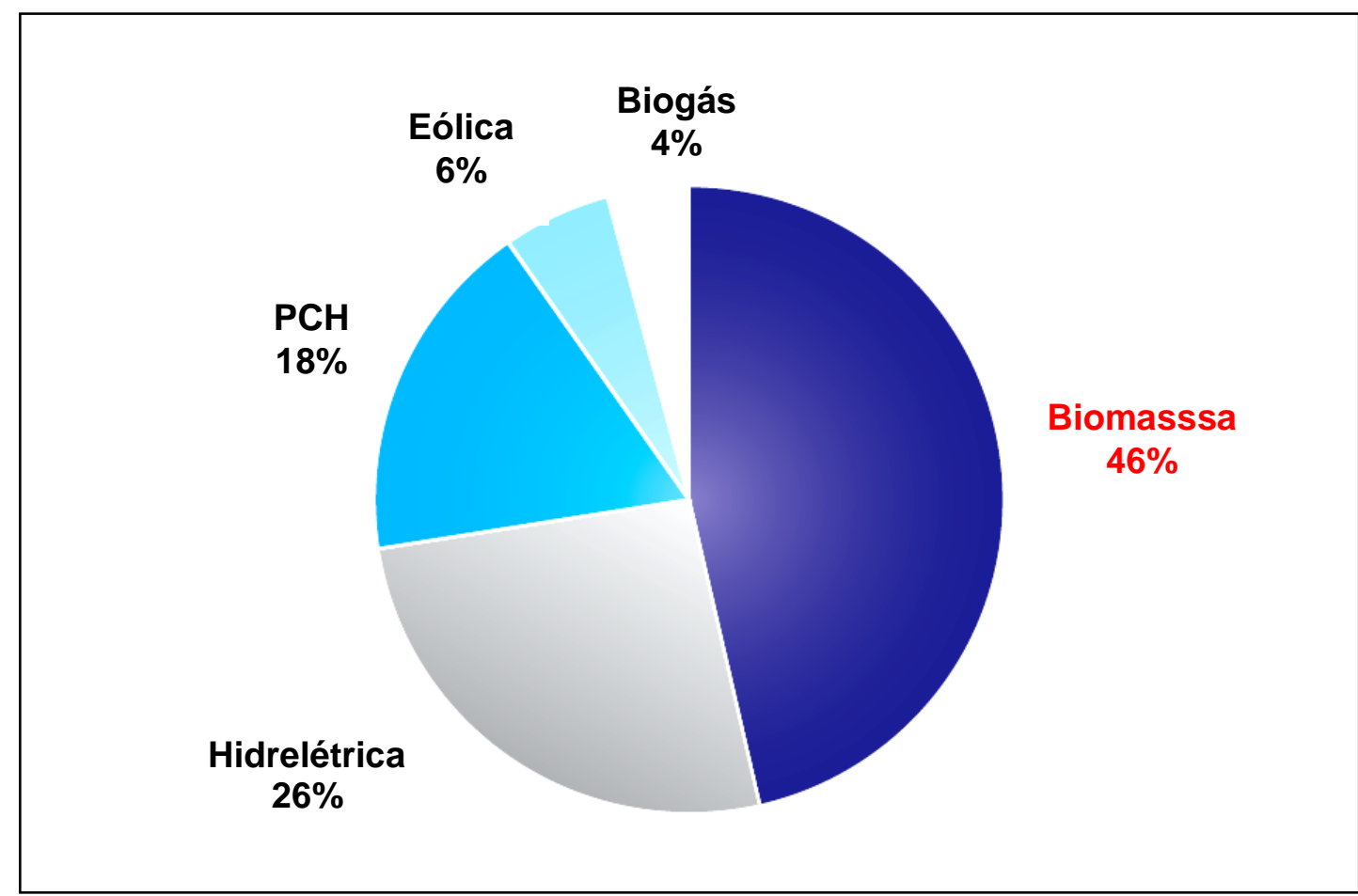

FIGURA 18 - Capacidade instalada em MW das atividades de projetos MDL aprovadas pelo CIMCG em $2008^{162}$.

Obs: $\mathrm{PCH}=$ Pequenas Centrais Hidrelétricas

No caso do Brasil, é mostrado na FIG. 19, que predominam os projetos relacionados ao setor agropecuário, distribuídos pela co-geração a partir da biomassa (80) e pelos projetos de suinocultura (41), seguidos pelos projetos de energia hídrica (52) e de aterros sanitários (29) ${ }^{174,175}$. 


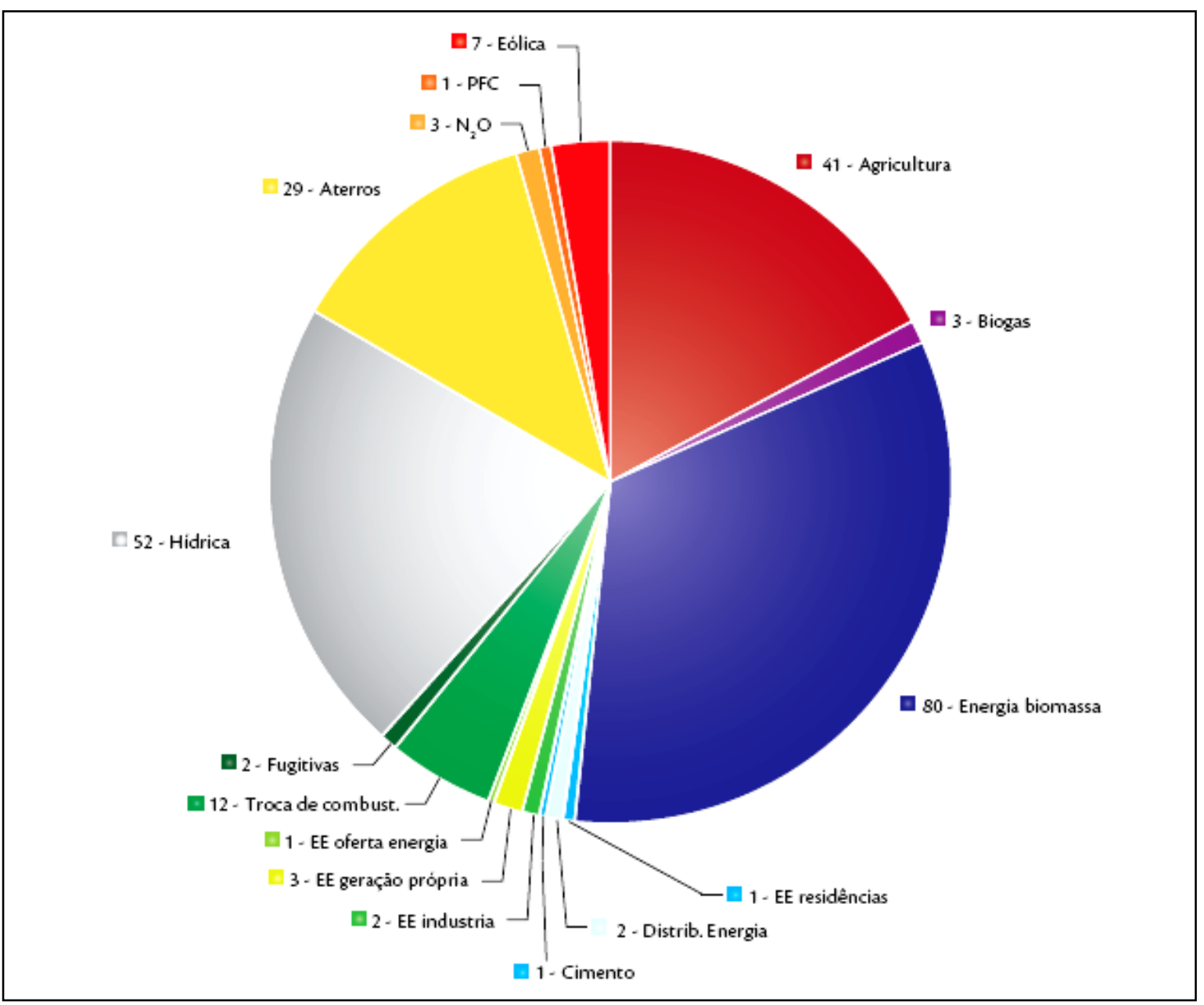

FIGURA 19 - Número de projetos MDL instalados no Brasil em $2008^{162,174}$.

\section{7. 2. Panorama no ano de $2009^{168,174,176,177}$}

Existem hoje 1.652 projetos em MDL registrados no Conselho Executivo da ONU e 211 em processo de registro ${ }^{177}$.

Na FIG. 20 é mostrada a posição de alguns países no âmbito de projetos de MDL. A China se consolidou na primeira posição mundial, com 1.608 projetos aguardando validação, 568 projetos registrados e um potencial de gerar 1.548.430 kRCEs* $^{*}$, até 2012, enquanto a Índia ocupa a segunda posição, com 662 projetos aguardando validação, 428 projetos registrados e com potencial de gerar $447.158 \mathrm{kRCEs}^{*}$, sendo que $\mathrm{kRCE}^{\star}=1.000 \mathrm{RCE}{ }^{168,176,177}$. 


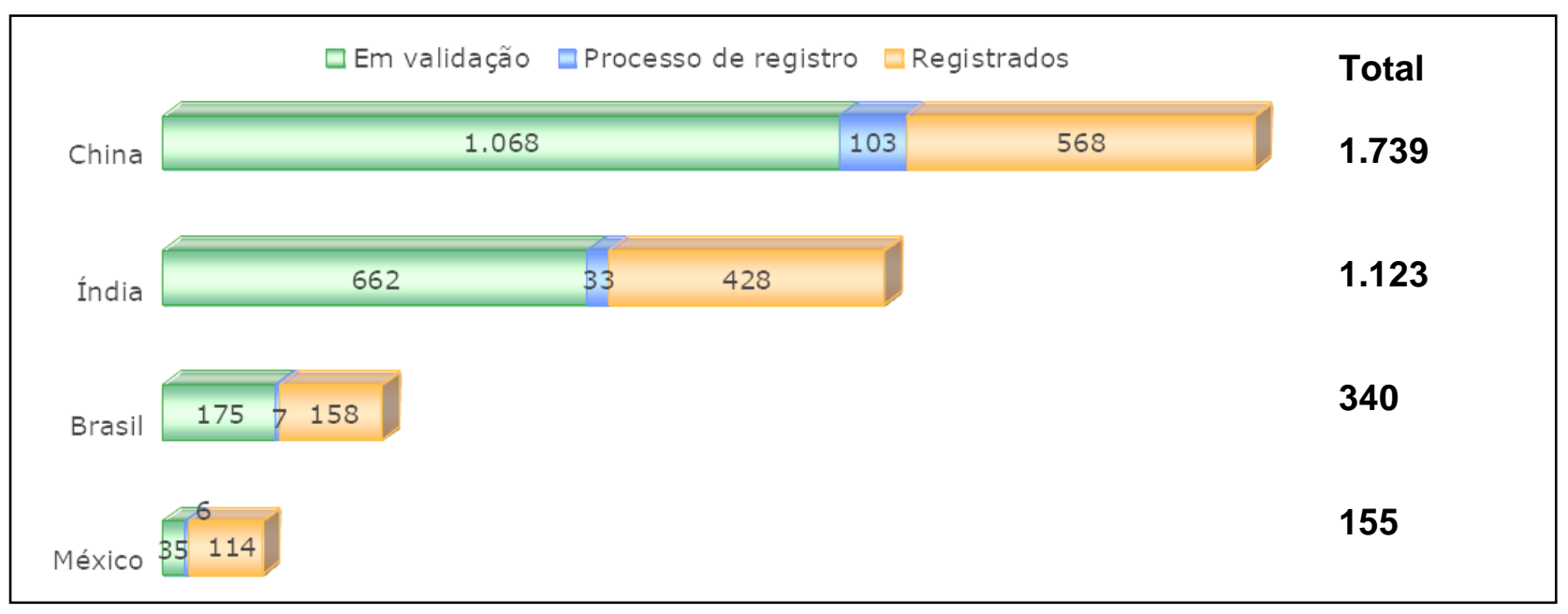

FIGURA 20 - Número de projetos de MDL instalados no Brasil e em alguns países do mundo, em janeiro de $2009^{168,174,176,177}$.

Segundo o mesmo levantamento, o Brasil continua ocupando a terceira posição absoluta (sendo que é a primeira posição latino americana), tanto em número de projetos - 340 - como em volume de RCEs a serem geradas até 2012 - 190.247 kRCEs - conforme é mostrado no diagrama da FIG. $21^{168,174,176,177 .}$

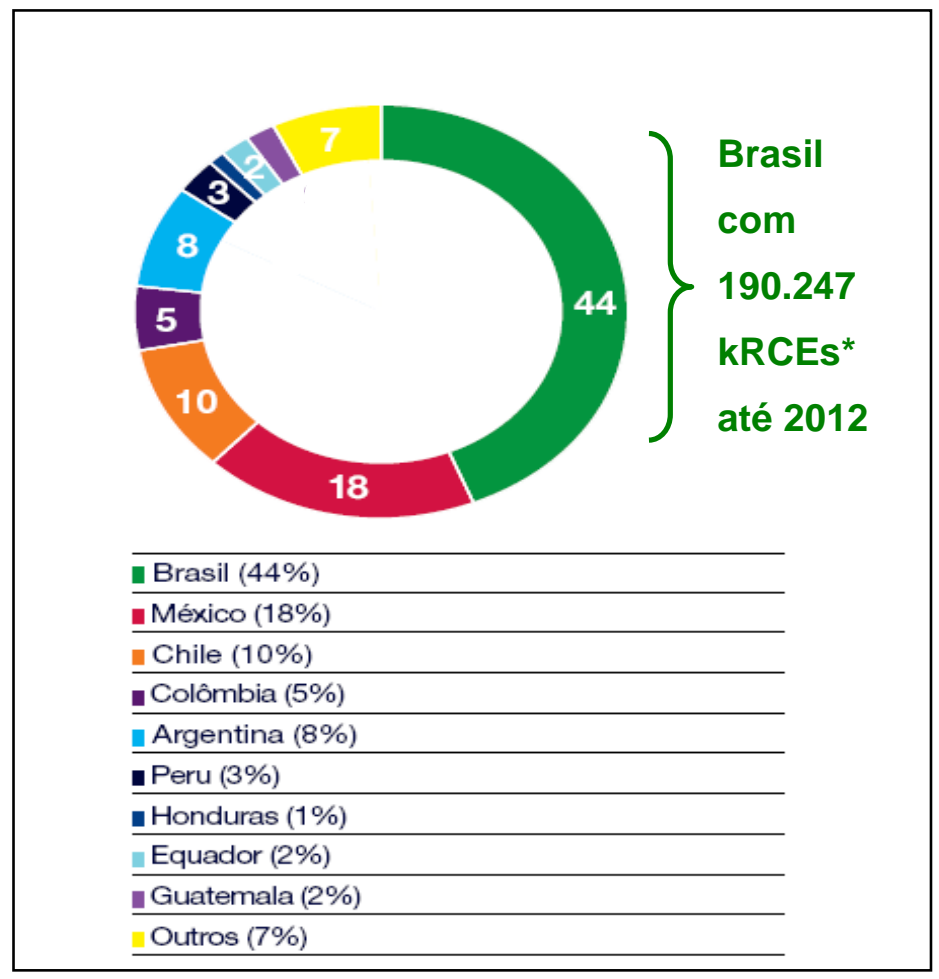

FIGURA 21 - Projeção, do volume de kRCEs, em porcentagem, possíveis de ser gerados até 2012, por países latino americanos. 
No caso do Brasil, conforme é mostrado na FIG. 22 há um aumento no número de projetos de 2008 para 2009, predominando aqueles no setor de cogeração a partir da biomassa - 108 - seguidos pelos de energia hídrica - 72.

O volume de RCEs gerados por projeto é mostrado no diagrama da FIG 23.

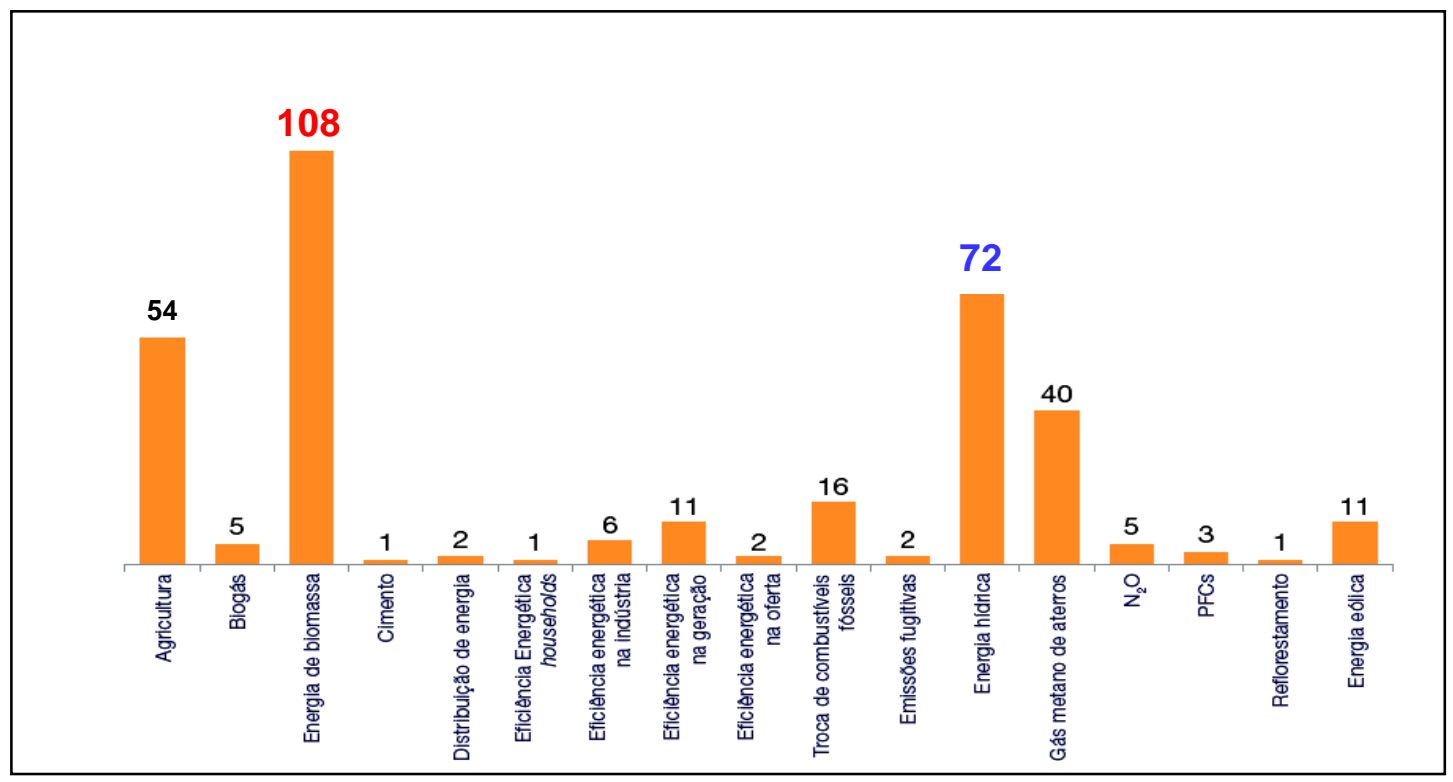

FIGURA 22 - Número de projetos MDL instalados no Brasil em $2009^{168,174,175}$.

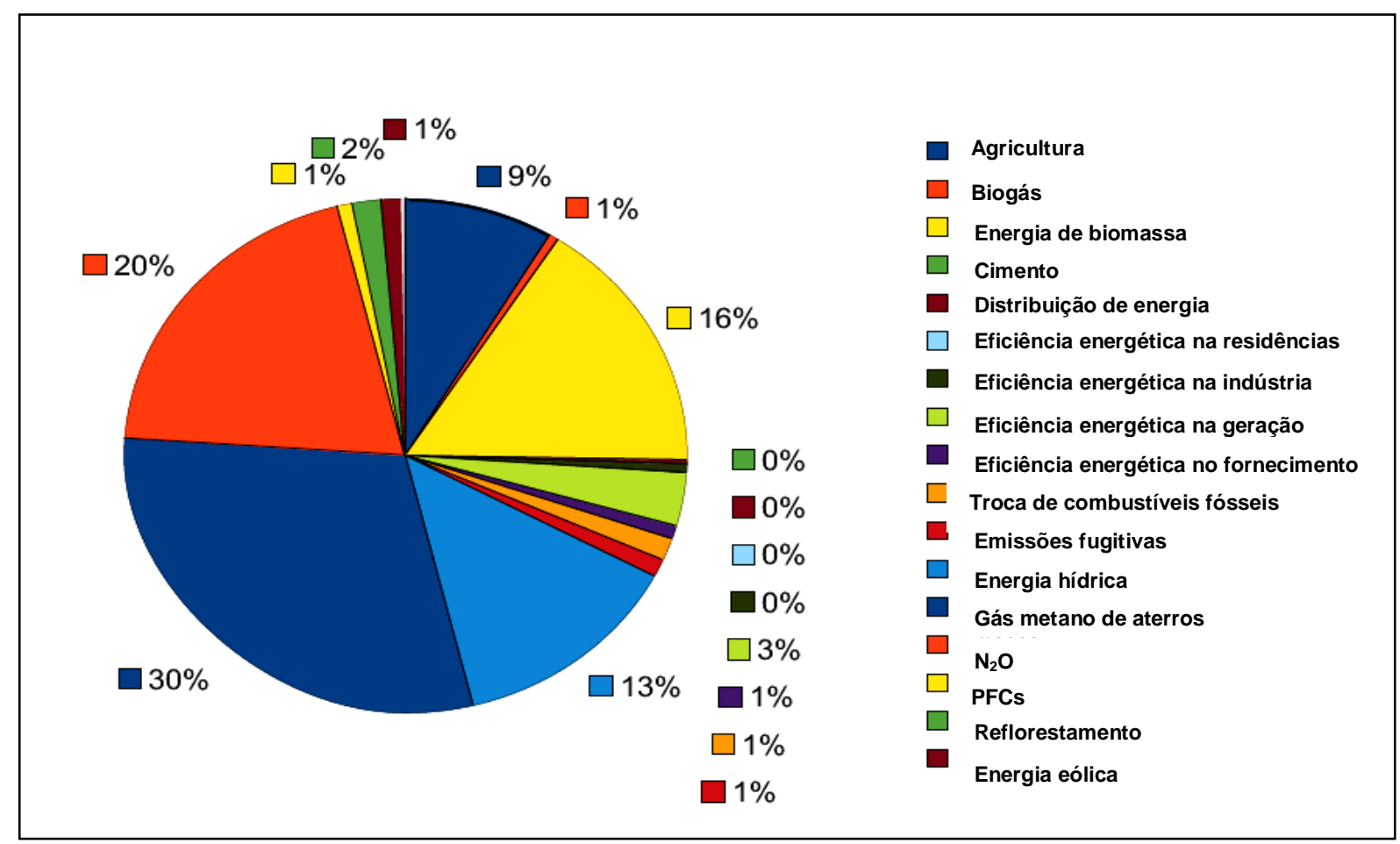

FIGURA 23 - Volume de RCEs brasileiras, em porcentagem, por tipo de projeto em 2009. ${ }^{168,174,175}$ 


\section{8. Os custos de transação de um MDL $87,141,162,178$}

Para submeter uma proposta de metodologia é preciso seguir os procedimentos estabelecidos pelo Comitê Executivo. Tais procedimentos têm sido criticados pelos proponentes, devido à complexidade e ao tempo entre a submissão da proposta de metodologia e sua aprovação ou rejeição.

Existem alternativas à submissão de novas metodologias, como, por exemplo, o pedido de revisão de uma metodologia, que pode ser feito por um proponente de projeto, e o processo de consolidação de metodologias, que está a cargo do Comitê Executivo do MDL.

Os custos de transação envolvidos no ciclo de aprovação e registro de uma atividade de projeto de MDL dependerão da escala desse projeto e são considerados como uma de suas principais barreiras.

Segundo Ingaramo e Sierra (2005), os chamados "custos de transação", variavam, em janeiro de 2007, com valores entre US\$110.000 - correspondendo a $R \$ 235.277,00$ ou $€ 85.020,79{ }^{178}$ - US\$250.000 - correspondendo a $R \$$ $535.175,00$ ou $€ 193.229,08^{178}$.

Esses valores, em muitos casos limitavam a viabilidade econômicofinanceira para projetos que geram pequeno volume de emissões de GEE.

Esses custos, porém, diminuíram nos últimos anos devido ao aumento da competição entre todos os atores privados envolvidos no ciclo das atividades de projeto MDL, como as EOD e empresas de consultoria.

O aprendizado desses participantes também tem evoluído, ou seja, os atores envolvidos têm aprendido com as experiências passadas e não têm repetido os mesmos erros de projetos anteriores, o que tem levado as transações a se tornarem um processo mais rápido e eficiente.

Em última análise, ainda existe espaço para aperfeiçoamentos em todas as etapas e, portanto, ainda existem potenciais reduções de custos, conforme é mostrado na FIG. $24^{162,179}$.

Os valores que nela estão indicados merecem a conversão para nossa moeda e para euros, conforme cotação feita em 09/09/2009.

Dessa forma teremos que o valor mínimo, US $\$ 60.000$, corresponde a $R \$$ $128.442,00$ ou $€ 46.374,98$, enquanto que o valor máximo, US\$175.000,00, corresponde a $R \$ 374.622,50$ ou $€ 135.260,35^{178}$. 


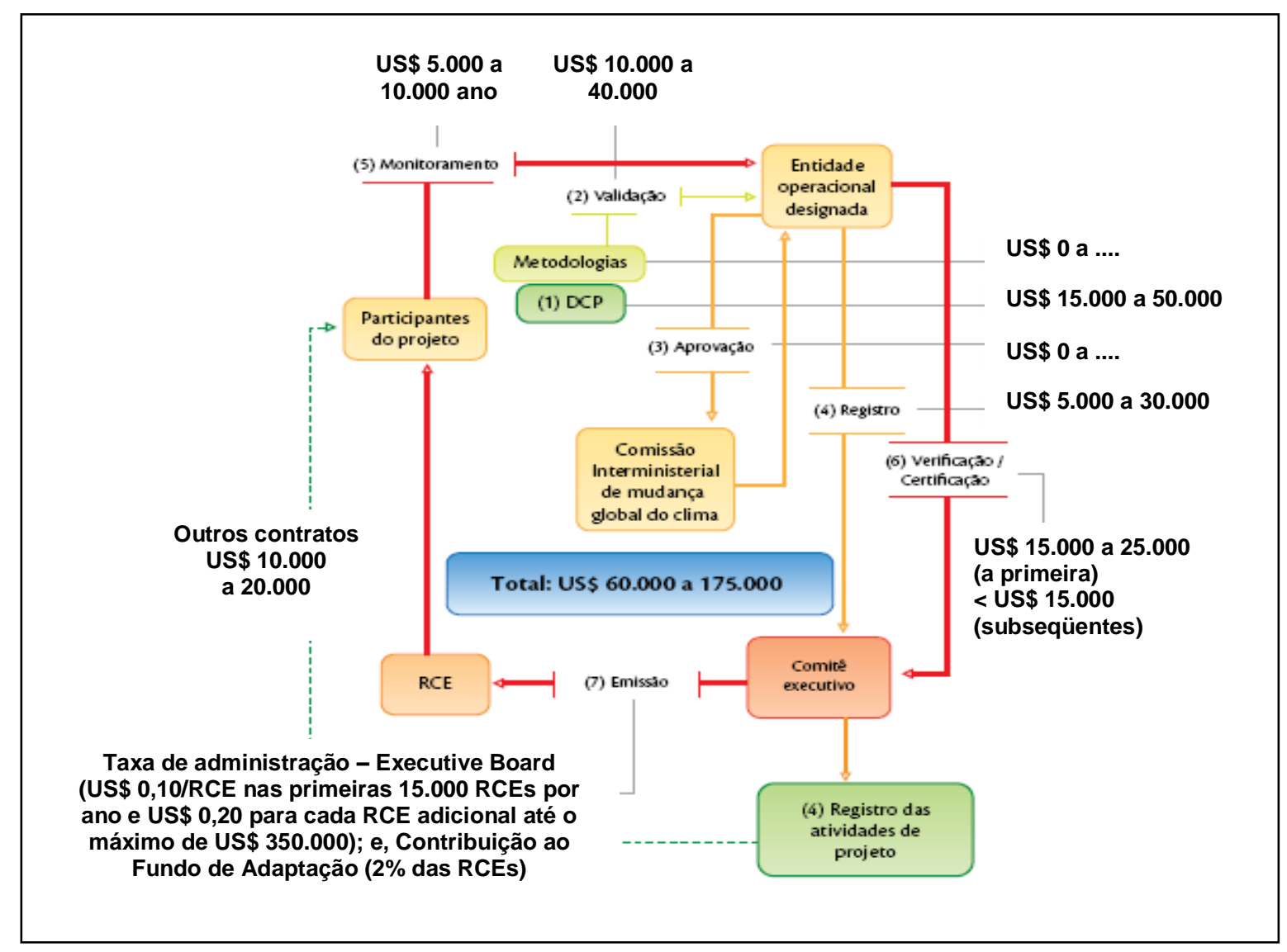

FIGURA 24- Custos de transação de um projeto de MDL, ano base $2009^{162,179 .}$

O impacto dos custos de transação sobre a viabilidade econômica dos projetos varia bastante conforme o tipo, tamanho do projeto e preço da RCE Alguns exemplos são marcantes: ${ }^{162,180,181,182}$

i. projetos de aproveitamento energético a partir do lixo de pequena escala (150 kW), o custo de transação pode representar até $46 \%$ da receita da comercialização das RCE;

ii. caso o projeto seja de larga escala (2 MW), o custo de transação representaria $17 \%$ da receita;

iii. o aproveitamento da energia em aterros sanitários de larga escala (11 MW) teria um custo de transação de apenas $11 \%$ da receita da comercialização das RCE;

iv. nos projetos de energia hídrica, os custos de transação representariam $8,9 \%$ e $34,7 \%$, respectivamente, para larga escala (155 MW) e pequena escala (5,8 MW); 
v. em um projeto de energia eólica (larga escala - $20 \mathrm{MW}$ ), o custo de transação poderia chegar a $23,7 \%$ da receita da comercialização das RCE;

vi. no caso de um projeto de energia solar de pequena escala (150 kW), o custo poderia ser superior a $640 \%$ da receita.

\section{8. 1. Atratividade de um MDL e inventário de emissões ${ }^{162,183}$}

Através dessas informações, algumas ainda conflitantes, percebe-se que é preciso, cada vez mais, que os projetos envolvendo créditos de carbono se insiram nas estratégias de sustentabilidade das empresas, como ferramentas de uma rápida identificação pública e privada, para uma diminuição de custos e para um aumento da sua credibilidade no mercado nacional ou internacional.

Empresas têm sido cobradas não apenas por seus retornos financeiros, mas também por suas responsabilidades sócio-ambientais, não se restringindo apenas a cumprir leis. Investidores e consumidores são hoje importantes atores que contribuem para a criação e o estabelecimento de políticas corporativas de sustentabilidade. Tornam-se necessários desafios e oportunidades decorrentes das mudanças climáticas que devem ocupar um papel central, devido à dimensão e às inter-relações que o efeito estufa representa.

Dentro desta linha, os projetos de MDL são considerados um componente estratégico de sustentabilidade e não podem ser concebidos ou implementados de forma isolada, tendo em vista, por exemplo, a melhoria logística e ambiental de outros projetos presentes numa empresa.

As empresas brasileiras estão iniciando um processo de internalização de projetos de MDL em suas estratégias de sustentabilidade, em resposta à demanda dos investidores nos mercados nacionais e internacionais.

Entre as estratégias que auxiliam a atratividade dos projetos de créditos carbono nesses mercados, merece destaque o "inventário de emissões", uma ferramenta útil na identificação de oportunidades de redução e mitigação das emissões de GEE. 
Um dos caminhos para se efetuar um inventário de emissões é realizado pelo Greenhouse Gas Protocol Initiative, que desenvolve padrões de contabilização e divulgação de GEE internacionalmente aceitos e aplicados ${ }^{183}$.

As emissões de GEE que serão mensuradas pelo GHG Protocol, estão divididas em três escopos, conforme mostrado no diagrama da FIG. 25:

i. Escopo 1 - (mensuração obrigatória) - emissões diretas de GEE provenientes de fontes que são de propriedade ou controladas pela empresa, como por exemplo, emissões da combustão em equipamento da empresa, veículos, entre outros;

ii. Escopo 2 - (mensuração obrigatória) - emissões indiretas de GEE provenientes, por exemplo, da geração da energia elétrica comprada e consumida pela empresa;

iii. Escopo 3 - (mensuração opcional) - outras emissões indiretas de GEE que ocorrem em outras empresas, porém que são decorrentes da demanda por produtos e serviços e/ou da utilização dos produtos e serviços gerados.

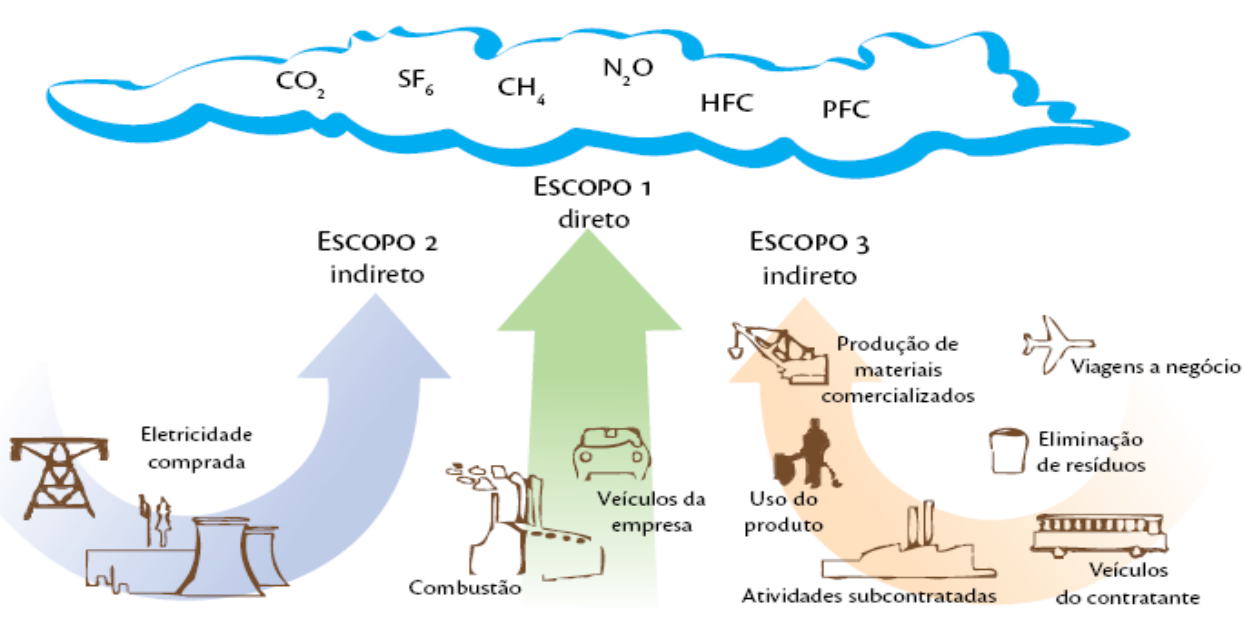

FIGURA 25 - Escopos de um inventário de emissões ${ }^{162,183,184}$. 


\section{9. A crescente demanda de energia no mundo}

O tamanho da população mundial, os padrões de consumo, a utilização de combustíveis fósseis e a eficiência energética são fatores que influenciam, para mais ou para menos, as emissões de gases de efeito estufa responsáveis pelo aquecimento global. Não há certezas de como esses fatores evoluirão no futuro, mas é possível construir cenários, combinando diferentes estimativas para cada fator. O IPCC e a ONU, reuniram cientistas de diferentes países, incluindo o Brasil, e construíram quatro diferentes cenários de desenvolvimento futuro, representando as alterações potenciais nos fatores acima, até o ano 2100.

Tais cenários são utilizados para projetar as possíveis mudanças climáticas globais e regionais: ${ }^{185,186,187,188,189}$

i. A1 - é o cenário de um mundo rico, com elevado crescimento econômico e baixo crescimento populacional. Tem rápida introdução e aplicação de tecnologias novas e eficientes e apresenta-se otimista para as emissões GEE.

ii. A2 - é o cenário de um mundo heterogêneo, com um grande fosso entre países ricos e pobres. Possui um enfoque pessimista e nele predomina o crescimento populacional rápido, além disso, o desenvolvimento econômico e a adoção de tecnologias é feito de forma lenta. Há, ainda, uso intensivo de combustíveis fósseis.

iii. B1 - é o cenário de um mundo sustentável e mais otimista. Nele há preocupações ambientais voltadas para o desenvolvimento de tecnologias que são rapidamente assimiladas em todo o planeta, evita-se o uso de combustíveis fósseis e busca-se atenuar o fosso entre ricos e pobres.

iv. B2 - é o cenário de um mundo tecnologicamente desequilibrado. Nele as soluções econômicas, sociais e ambientais são locais e o uso das inovações tecnológicas se desenvolvem rapidamente apenas em algumas regiões, enquanto que em outras continuam a ser empregadas técnicas antiquadas.

Na FIG. 26 é mostrado graficamente, como evoluirão as emissões de $\mathrm{CO}_{2}$ em cada cenário: ${ }^{185,188,189}$ 


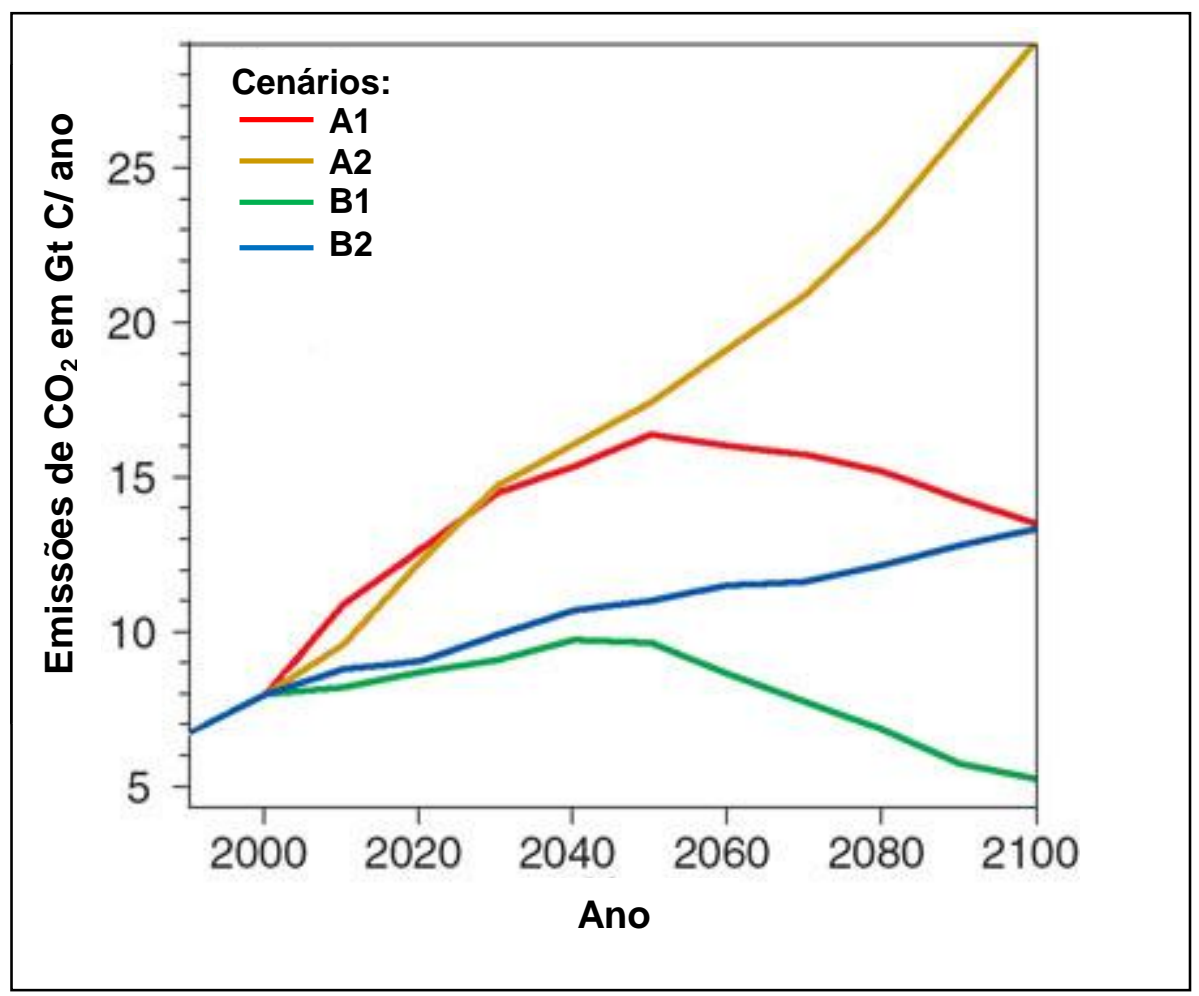

FIGURA 26 - Como poderão evoluir as emissões de $\mathrm{CO}_{2}$ no século XXI, conforme os quatro diferentes cenários, de acordo com o IPCC e a ONU.

O panorama mundial está ligado a três grandes preocupações: o meio ambiente, a energia e a economia global, e, apesar de serem aparentemente distintas, as três estão completamente interligadas.

As duas primeiras aparecem mais frequentemente na percepção do cidadão comum devido ao efeito estufa e ao aquecimento global associado ao uso de combustíveis fósseis.

Quanto à economia, só o tempo poderá dizer os efeitos permanentes desta crise no sistema financeiro internacional sobre o setor energético e, o mais difícil de prever: como isso irá afetar o meio ambiente. Porém, indubitavelmente, os três setores serão permanentemente afetados.

Não importa qual a saída adotada, ela deverá passar por uma mudança radical na matriz energética mundial, com forte aumento da participação das fontes renováveis. De 2006 a 2030, a utilização mundial de energias renováveis deve crescer uma média de 2,9\% por ano, atingindo, em 2030, uma participação de $21 \%$, contra $19 \%$ em $2006^{189}$. 
Ainda assim, no cenário mundial de geração de eletricidade, o carvão e o gás natural serão responsáveis por quase dois terços de geração elétrica em 2030, conforme é mostrado no diagrama da FIG. $27^{189,190,191}$.

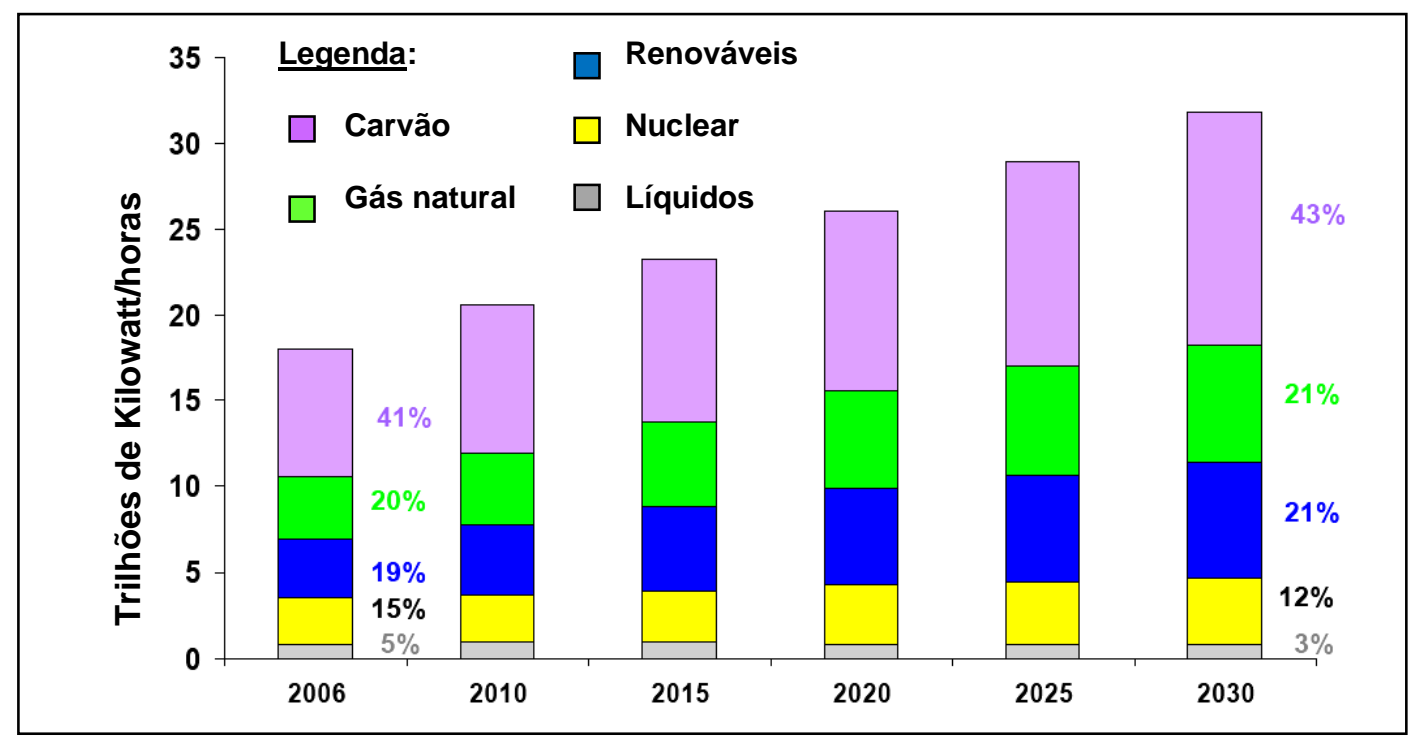

FIGURA 27 - Cenário mundial de fontes de energia - 2006 a $2030{ }^{189}$.

Globalmente, a demanda por energia crescerá de 398 Quad de BTUS em 2000 para 678 Quad de BTUS em $2030{ }^{192}$. O maior crescimento econômico e a contínua dependência de combustíveis fósseis é previsto para a maioria das economias em desenvolvimento, devendo ocorrer em maior demanda, no grupo de países denominado genericamente de BRIC - Brasil, Rússia, Índia e China conforme relatório anual recém divulgado sobre Perspectivas Energéticas Internacionais e mostrado na FIG. $28^{189,192,193,194}$.

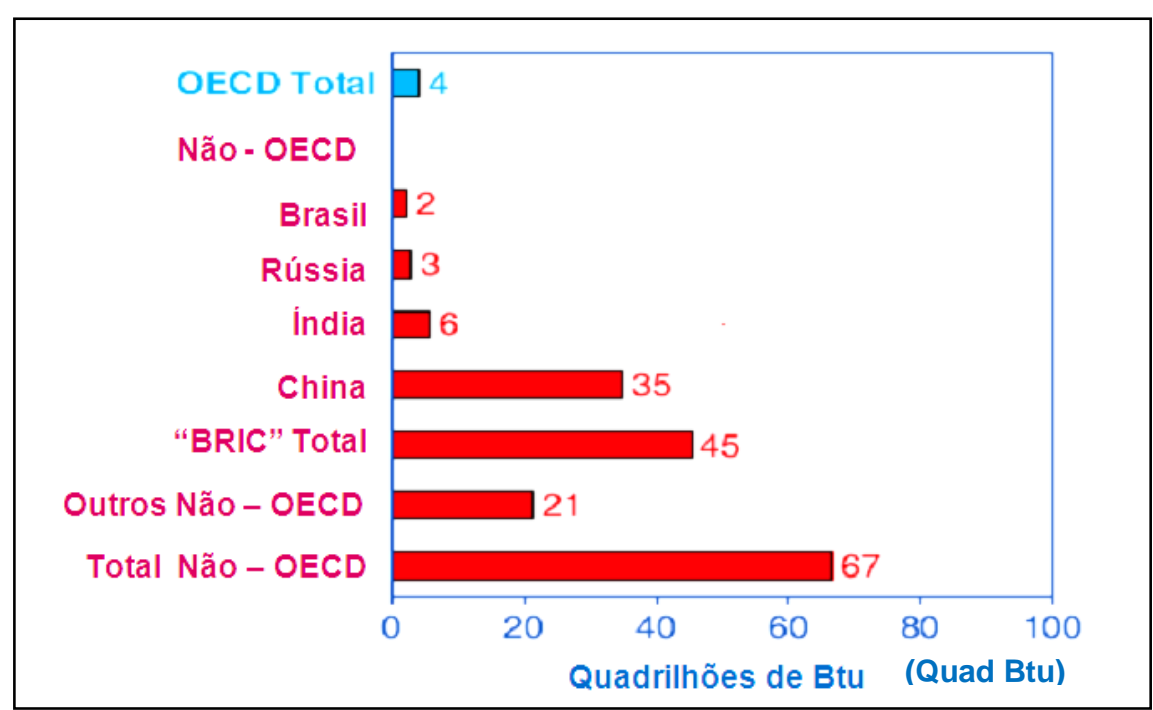

FIGURA 28 - Projeção do aumento no uso da rede de energia por região entre 2006 a $2030^{189,194}$. 


\section{10. A crescente demanda de energia no Brasil}

A mudança do clima resultará num aumento de até $9 \%$ do consumo de energia elétrica no setor residencial e de até $19 \%$ no setor de serviços, elevando em $8 \%$ o consumo total de eletricidade projetado para $2030^{182,195}$.

Em 2005, o consumo de eletricidade representou 33\% do total de energia nos lares brasileiros. Em 2030, nesse item, a Empresa de Pesquisa Energética (EPE) projeta que esse consumo será superior a 60\%. Já nos setores comercial e público, apesar de sua participação ser substancialmente mais alta, não deverá crescer tanto, passando de 83\%, em 2005, para 85\%, em $2030{ }^{195,196}$.

A EPE, em 2005, estimou que o uso de aparelhos de ar-condicionado nas casas chegou a 7,6 TWh (9,2\% do total). Em 2030, projeta-se 14,8 TWh (5,2\% do total). Já no setor de serviços, estima-se que $20 \%$ do consumo de eletricidade destinam-se aos sistemas de condicionamento de ar $^{186,197}$.

As políticas adotadas nos últimos 25 anos para o abastecimento de energia foram, de modo geral, bem-sucedidas. A "aparente" auto-suficiência em petróleo e o aumento no uso de fontes renováveis de energia, como o álcool, são exemplos desse sucesso. No entanto, as políticas para aumentar a eficiência energética e expandir o uso dessas fontes, mostram resultados extremamente insatisfatórios e bem mais limitados. Diante dos potenciais impactos ambientais sobre a oferta de energia, urge propor medidas que otimizem o uso racional e a eficiência energética, expandindo a oferta por meio do uso de fontes de energias alternativas, baseadas, por exemplo, no uso de resíduos sólidos urbanos, em biomassa, em eólica, em células a combustível, entre outras.

Todas essas propostas, entretanto, ainda representam grandes lacunas no conhecimento científico brasileiro, que precisam ser preenchidas através de incentivos com novos estudos e pesquisas, garantindo a segurança energética do país e evitando sua vulnerabilidade no cenário atual ou naquele que se prevê diante das mudanças climáticas.

A expansão dos sistemas de geração de energia elétrica baseado em fontes convencionais tende a se tornar cada vez mais difícil, pelas crescentes restrições ambientais. Mais de $60 \%$ do potencial hidrelétrico brasileiro remanescente está na Amazônia ${ }^{186}$, e seu aproveitamento é, ou será limitado, pelas restrições ao desmatamento de grandes áreas para instalação de reservatórios. 
Na TAB. 13 apresenta-se o cenário que mostra o impacto estimado das mudanças climáticas sobre o consumo de energia final e o de eletricidade, projetados pela EPE, para 2030. Na tabela também estão consideradas as projeções para os cenários A2 e B2 ${ }^{198,199,200}$.

TABELA 13 - Variação sobre o consumo total de energia e o consumo de eletricidade previstos para 2030 considerando-se as mudanças climáticas ${ }^{186}$.

\begin{tabular}{|c|c|c|c|c|c|c|c|}
\hline & & \multicolumn{3}{|c|}{ Cenário A2 } & \multicolumn{3}{|c|}{ Cenário B2 } \\
\hline & 2030 & 2080 & 2090 & 2100 & 2080 & 2090 & 2100 \\
\hline $\begin{array}{c}\text { Total } \\
\text { (ktep) }^{*}\end{array}$ & 402.821 & 406.202 & 407.521 & 409.304 & 405.697 & 404.146 & 404.008 \\
\hline Residencial & 40.621 & 41.382 & 41.914 & 42.550 & 41.297 & 40.853 & 40.855 \\
\hline Serviços & 26.955 & 29.415 & 30.201 & 31.348 & 28.995 & 27.888 & 27.748 \\
\hline $\begin{array}{c}\text { Eletricidade } \\
(\mathrm{TWh})^{\star \star}\end{array}$ & 947 & 986 & 1.001 & 1.022 & 980 & 962 & 960 \\
\hline Residencial & 283 & 294 & 300 & 308 & 293 & 288 & 288 \\
\hline Serviços & 267 & 296 & 305 & 318 & 291 & 278 & 277 \\
\hline
\end{tabular}

Legenda: *ktep - mil toneladas equivalentes de petróleo - a tonelada equivalente de petróleo (tep) é uma unidade de energia equivalente à quantidade de energia liberada pela queima de uma tonelada de petróleo bruto.

** TWh - terawatts hora - equivale $1.000 \mathrm{GWh}\left(1 \mathrm{GWh}=\mathrm{a} 10^{9} \mathrm{Wh}\right)$

Fontes movidas a combustíveis fósseis emitem GEE, têm limitações econômicas pela volatilidade dos preços e desestimulam investimentos nesse setor. Assim, a utilização de fontes alternativas de energia para aumentar a oferta de eletricidade tende a se tornar mais atraente, sobretudo num quadro de mudança do clima global. 


\section{11. O cenário mundial das emissões de $\mathrm{CO}_{2}$}

O aquecimento global é o desafio da atualidade. É preciso criar mecanismos que viabilizem a redução das emissões de GEE, assunto discutido na CQNUMC na década de 90 . Desde então, o mundo prestou maior atenção ao perfil de suas atividades econômicas, e em como este perfil contribui para essas emissões, vendo nisso um poder de barganha no cenário internacional.

O ano de 2009 deve ser uma referência na definição de diretrizes e metas de mercado pautados em dados comparativos de emissões dos países, a partir de diferentes óticas, pois é sabido que toda atividade humana emite GEE, em diferentes intensidades, com características econômicas próprias e de acordo com a disponibilidade de recursos naturais de um país.

Atualmente, os maiores vilões globais são a geração de energia, indústria, mudança no uso do solo e floresta, agricultura, transporte, construções e resíduos. As expectativas apontam para o aumento dos setores de eletricidade e transporte, sugerindo-se atenção na definição e promoção de políticas e investimentos tecnológicos para estes setores ${ }^{201}$. Na FIG. 29 são mostradas as emissões de GEE de cada setor ${ }^{13}$.

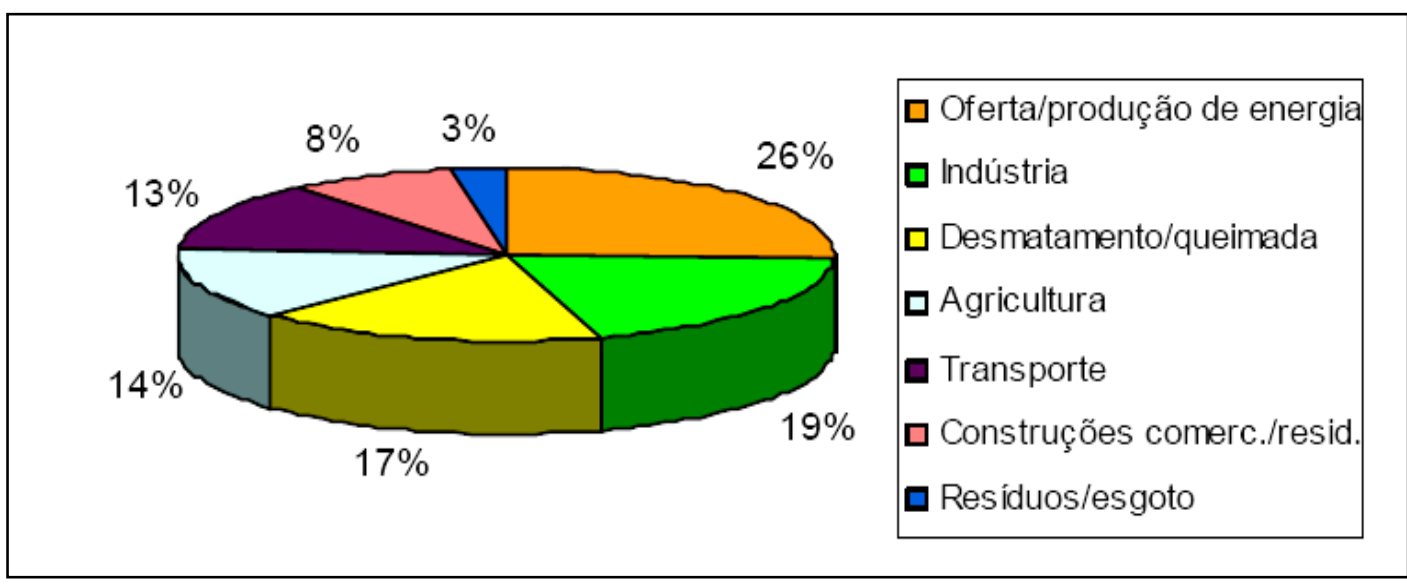

FIGURA 29 - Participação dos diferentes setores nas emissões antropogênicas totais de GEE, em termos de $\mathrm{CO}_{2}$ eq ${ }^{13}$.

Apesar de a maioria das grandes empresas mundiais possuir planos para controle de suas emissões ${ }^{168}$, estudos indicam que os objetivos a ser atingidos são ainda tímidos e, com base nas atuais metas de redução, as maiores empresas mundiais atingirão os níveis recomendados de emissão de GEE pelo 
IPCC, só em 2089, ou seja, 39 anos depois do que seria esperado para se evitar as piores conseqüências das mudanças climáticas ${ }^{202,203}$.

Os cortes programados atualmente alcançariam, no máximo, a cifra de $1,9 \%$ por ano, quando a meta deveria ser de $3,9 \%$, ou seja, bem inferior ao mínimo necessário para que as economias desenvolvidas atinjam a cota de redução de $80 \%$ de emissões até 2050 175,204,205,206.

De acordo com estudos do IEO 2009, em termos globais, a demanda por energia crescerá, lado a lado com as emissões de $\mathrm{CO}_{2}$ de cerca de 29 bilhões de toneladas métricas em 2006 para 40,4 bilhões em 2030, ou seja, mantendo-se as atuais políticas energéticas, as emissões aumentarão mais de 44\% até 2030 em relação aos níveis de 2006, como é mostrado na FIG. $30^{192}$.

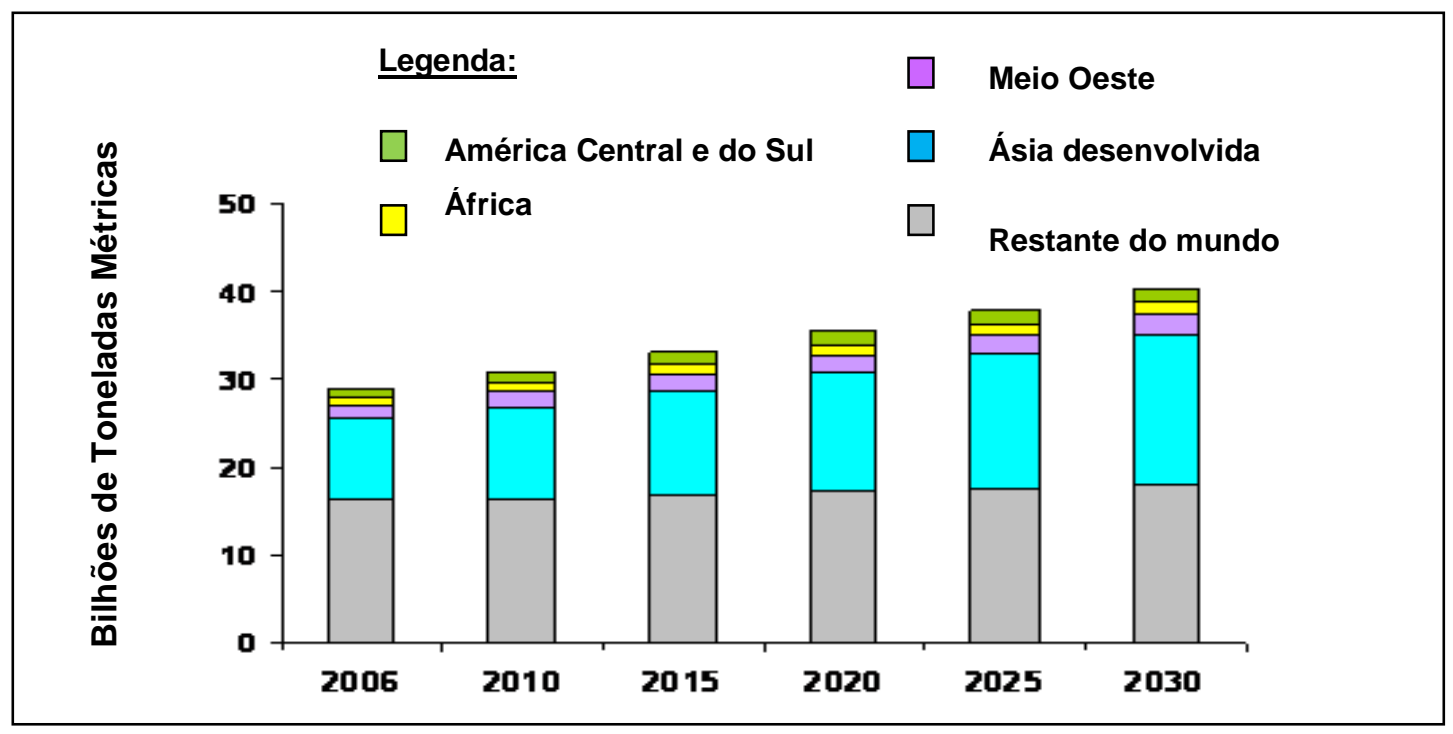

FIGURA 30 - Relação demanda de energia mundial e emissões de $\mathrm{CO}_{2}{ }^{192}$.

Desde o início das negociações do Protocolo de Kyoto, instituições internacionais - públicas e privadas - trabalham nas questões econômicofinanceiras envolvidas em sua implementação, ainda com algumas incertezas sobre o assunto, afetando seu processo produtivo e, portanto o perfil energético.

Muito se comenta sobre as emissões totais de um país ou de um grupo de países, mas uma análise das emissões anuais per capita acaba por revelar números de interesse, abrindo perspectivas de trabalhos com um MDL, cujo enfoque evite emissões e os custos com essa redução. 
Estimativas como essas, apresentam-se na TAB. 14, comparando anos extremos - 1990 e 2008 - baseadas no consumo de combustíveis fósseis.

TABELA 14 - Evolução das emissões $\mathrm{CO}_{2}$ / capita / tonelada, entre 1990 - 2008 de alguns países selecionados ${ }^{207,208,209}$.

\begin{tabular}{|c|c|c|c|c|c|c|c|c|c|}
\hline & País & 1990 & 2008 & Diferença & & País & 1990 & 2008 & Diferença \\
\hline & & ${ }^{\star} A n \epsilon$ & $\overline{\text { xol }}$ & & & & Não-I & nexol & \\
\hline 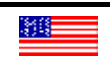 & $\overline{E U A}$ & 19,3 & 18,5 & $-0,8$ & & China & 2,2 & 5,7 & 3,6 \\
\hline & EU & 9,1 & 8,5 & $-0,6$ & 3 & Índia & 0,8 & 1,4 & 0,6 \\
\hline & França & 6,7 & 6,4 & $-0,3$ & $\theta$ & Brasil & 1,5 & 2,2 & 0,7 \\
\hline & Alemanha & 12,8 & 9,8 & $-3,0$ & 8 & México & 3,7 & 4,2 & 0,5 \\
\hline & Itália & 7,5 & 8,3 & 0,8 & $\%$ & Irã & 3,6 & 6,9 & 3,3 \\
\hline & Espanha & 5,8 & 7,9 & 2,1 & $*$ & $\begin{array}{l}\text { Coréia } \\
\text { do Sul }\end{array}$ & 5,9 & 10,8 & 4,9 \\
\hline 部告 & $\begin{array}{l}\text { Reino } \\
\text { Unido }\end{array}$ & 10,2 & 8,7 & $-1,5$ & 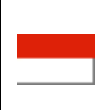 & Indonésia & 0,9 & 1,8 & 0,9 \\
\hline 8 & Japão & 9,2 & 10,0 & 0,8 & & & & & \\
\hline & Austrália & 16,0 & 18,3 & 2,3 & & & & & \\
\hline 1*1 & Canadá & 16,1 & 17,0 & 0,9 & & & & & \\
\hline & Rússia & 15,7 & 11,9 & $-3,8$ & & & & & \\
\hline & Ucrânia & 14,8 & 7,9 & $-6,9$ & & & & & \\
\hline
\end{tabular}

Legenda: * Os países do Anexo I são os países industrializados, com um objetivo de emissões sob o cunho do Protocolo de Kyoto.

\section{12. $\mathrm{O}$ cenário brasileiro das emissões de $\mathrm{CO}_{2}$}

Embora países em desenvolvimento, como o Brasil, não tenham compromissos de redução ou de limitações em suas emissões de GEE, o país procura desenvolver programas e ações que resultem em uma redução significativa dessas emissões. 
Cita-se como exemplo, 0 fato de termos uma matriz energética relativamente "limpa", levando a menores emissões por unidade de energia produzida ou consumida. Porém, as emissões mais importantes consideradas em um levantamento feito no Primeiro Inventário Brasileiro de Emissões, no período de 1990 a 1994, já fornecem números alarmantes, como por exemplo, os do $\mathrm{CO}_{2}$, com 1.029.706 Gg/ano 196,210,211.

Na TAB. 15 apresentam-se esses dados ${ }^{210}$.

TABELA 15 - Estimativa das emissões e remoções de $\mathrm{CO}_{2}$ em alguns setores do Brasil, em $1994{ }^{210}$.

\begin{tabular}{cccc}
\hline $\begin{array}{c}\text { Setor de } \\
\text { energia }\end{array}$ & $\begin{array}{c}\text { Setor de } \\
\text { processos } \\
\text { industriais }\end{array}$ & $\begin{array}{c}\text { Setor de } \\
\text { mudança no } \\
\text { uso da terra } \\
\text { e florestas }\end{array}$ & $\begin{array}{c}\text { Total } \\
\text { Gg*/ano }\end{array}$ \\
\hline $236.505 \mathrm{Gg}$ & $16.870 \mathrm{Gg}$ & $776.331 \mathrm{Gg}$ & $1.029 .706 \mathrm{Gg}$ \\
ou & ou & ou & ou \\
$\sim 237 \mathrm{Tg}$ & $\sim 17 \mathrm{Tg}$ & $\sim 776 \mathrm{Tg}$ & $\sim 1.030 \mathrm{Tg}$ \\
& & & \\
\hline
\end{tabular}

\begin{tabular}{ccccc}
\hline Variação & & & & \\
percentual & $\sim 16 \%$ & $\sim 2 \%$ & $\sim 2 \%$ & $\sim 5 \%$ \\
$1990 / 1994$ & & & & \\
\hline
\end{tabular}

Ao final de 2009, o Brasil deverá apresentar o Segundo Inventário Nacional de Emissões, que de forma semelhante ao Primeiro Inventário, trará um retrato real da contribuição do país nas emissões de GEE ao aquecimento global, por setores e por volume ${ }^{211}$.

Todos os países signatários da CQNUMC devem apresentar esses inventários. As nações desenvolvidas, com metas de corte de emissões definidas, o fazem todos os anos, e os países em desenvolvimento, como o Brasil, apenas periodicamente. 
Para a elaboração deste relatório, os países contam com recursos do Global Environment Facility (GEF), um fundo financiado pelas nações industrializadas ${ }^{212}$.

Além do inventário, deve ser feita uma Comunicação Nacional, onde se identificarão todas as ações que um país está tomando no combate da mudança climática. Ele é fundamental para entender como o país contribui nessas emissões e assim trace ações políticas e públicas nessas reduções.

Seguindo essa linha de metas, um estudo do IBGE (Instituto Brasileiro de Geografia e Estatística) e da EPE (Empresa de Planejamento Energético), ligadas ao MME (Ministério de Minas e Energia), ressaltou o crescimento da geração de energia elétrica no país de 1994 a 2007, afirmando que, dois setores, o industrial e o de geração e consumo de energia (devido à ampliação de termoelétricas, e ao aumento no consumo de combustíveis fósseis), somados, terão um peso expressivo no total de emissões de $\mathrm{CO}_{2}$.

A área técnica do MMA estimou que, em 1994, as emissões de $\mathrm{CO}_{2}$ dos dois setores, representavam $90 \%$ do total liberando, juntos, $253.375 \mathrm{Gg}$ de $\mathrm{CO}_{2}$, como apresentado na TAB. 15 da página anterior ${ }^{210}$.

Em termos de geração de energia, em 1994, as emissões de $\mathrm{CO}_{2}$ ficaram em cerca de $71 \%$, mas os resultados do estudo elaborado pelos órgãos citados acima, indicaram que houve um aumento para $122 \%$ em 2007. O crescimento da produção final de energia elétrica acabou por tornar-se 30\% mais poluente em gás carbônico, como apresentado na TAB. 16.

TABELA 16 - Intensidade de emissões de $\mathrm{CO}_{2}$ na geração de energia elétrica no país -1994 e $2007^{210,213}$.

\begin{tabular}{cccc}
\cline { 2 - 4 } & $\mathbf{1 9 9 4}$ & $\mathbf{2 0 0 7}$ & Variação \\
\hline Geração de Energia (GWh) & 260.041 & 444.583 & $71 \%$ \\
Emissões de $\mathrm{CO}_{2}(\mathrm{Gg})$ & 10.849 & 24.117 & $122 \%$ \\
Intensidade $(\mathrm{Gg} \mathrm{CO} / \mathrm{GWh})$ & 42 & 54 & $\mathbf{3 0 \%}$ \\
\hline
\end{tabular}

Considerando-se todos os segmentos responsáveis pelas emissões de $\mathrm{CO}_{2}$, que utilizam como fonte os combustíveis fósseis e os processos industriais, 
o aumento geral, foi em torno de $49 \%$ e, segundo as estimativas dos órgãos citados anteriormente, esses valores passaram de 225,2 Gg, em 1994, para 334,6 Gg emitidas, em 2007, como apresenta-se na TAB. 17.

TABELA 17 - Estimativa de emissões de $\mathrm{CO}_{2}$, por combustíveis fósseis, por setor entre 1994 e $2007^{182,210,214}$.

\begin{tabular}{cccccc}
\hline Setor & $\begin{array}{c}\text { Emissões } \\
\mathbf{1 9 9 4}(\mathbf{G g})\end{array}$ & $\begin{array}{c}\text { Participação } \\
\mathbf{1 9 9 4}(\%)\end{array}$ & $\begin{array}{c}\text { Emissões } \\
\mathbf{2 0 0 7}(\mathbf{G g})\end{array}$ & $\begin{array}{c}\text { Participação } \\
\mathbf{2 0 0 7}(\%)\end{array}$ & $\begin{array}{c}\text { Variação } \\
\text { entre 1994 e } \\
\mathbf{2 0 0 7}(\%)\end{array}$ \\
\hline Energético & 14.753 & 6,55 & 24.691 & 7,38 & 67,36 \\
Residencial & 15.176 & 6,74 & 16.115 & 4,81 & 6,18 \\
Comercial & 1.557 & 0,69 & 1.995 & 0,60 & 28,13 \\
Público & 1.962 & 0,87 & 1.813 & 0,54 & $-7,59$ \\
Agropecuário & 12.516 & 5,56 & 16.089 & 4,81 & 28,54 \\
Termelétricas & 10.849 & 4,82 & 24.117 & 7,20 & 122,30 \\
Transporte & $\mathbf{9 4 . 3 2 4}$ & 41,88 & $\mathbf{1 4 6 . 8 4 9}$ & 43,87 & $\mathbf{5 5 , 6 8}$ \\
Indústria & 74.066 & 32,89 & 103.027 & 30,78 & 40,10 \\
\hline Total & $\mathbf{2 2 5 . 2 0 3}$ & 100 & $\mathbf{3 3 4 . 6 9 6}$ & 99,99 & $\mathbf{4 8 , 6 2}$ \\
\hline
\end{tabular}

Outro setor de destaque nesse item foi o de transportes, que, no período analisado, passou de $94,3 \mathrm{Gg}$ de $\mathrm{CO}_{2}$ emitidas, para $146,8 \mathrm{Gg}$, computando um aumento de cerca $56 \%$.

O meio rodoviário, no ano de 1994 representava cerca de $88 \%$ do total das emissões de $\mathrm{CO}_{2}$, e em 2007, acabou por elevar essa participação para $90 \%$.

Já o meio hidroviário obteve queda de $4 \%$ para $3 \%$.

Na TAB. 18 apresentam-se os valores expostos até o momento ${ }^{210,213}$. 
TABELA 18 - Estimativa de emissões de $\mathrm{CO}_{2}$ advindas de combustíveis fósseis, no setor de transportes - 1994 e $2007^{210,213}$.

\begin{tabular}{cccccc}
\hline Transporte & $\begin{array}{c}\text { Emissões } \\
\mathbf{1 9 9 4} \\
\mathbf{( G g )}\end{array}$ & $\begin{array}{c}\text { Participação } \\
\mathbf{1 9 9 4} \\
\mathbf{( \% )}\end{array}$ & $\begin{array}{c}\text { Emissões } \\
\mathbf{2 0 0 7} \\
\mathbf{( G g )}\end{array}$ & $\begin{array}{c}\text { Participação } \\
\mathbf{2 0 0 7} \\
\mathbf{( \% )}\end{array}$ & $\begin{array}{c}\text { Variação } \\
\text { entre 1994 } \\
\text { e 2007 } \\
(\%)\end{array}$ \\
\hline Rodoviário & 83.302 & $\mathbf{8 8}$ & 132.768 & $\mathbf{9 0}$ & 59 \\
Ferroviário & 1.260 & 1 & 1.803 & 1 & 43 \\
Aéreo & 6.204 & 7 & 7.999 & 5 & 29 \\
Hidroviário & 3.558 & 4 & 4.279 & 3 & 20 \\
\hline Total & 94.324 & 100 & 146.849 & 100 & 56 \\
\hline
\end{tabular}

Os combustíveis fósseis são ainda uma parcela significativa da geração de energia no setor de transportes e de termelétricas, visto que liberam o carbono neles armazenado num tempo bem menor do que aquele que ele levaria para se converter em mineral novamente, acumulando-se na atmosfera em forma $\mathrm{CO}_{2}$.

$\mathrm{Na}$ FIG. 31 é mostrado como, no cenário nacional, as emissões de $\mathrm{CO}_{2}$ apresentam-se no setor de transportes ${ }^{210,213}$.

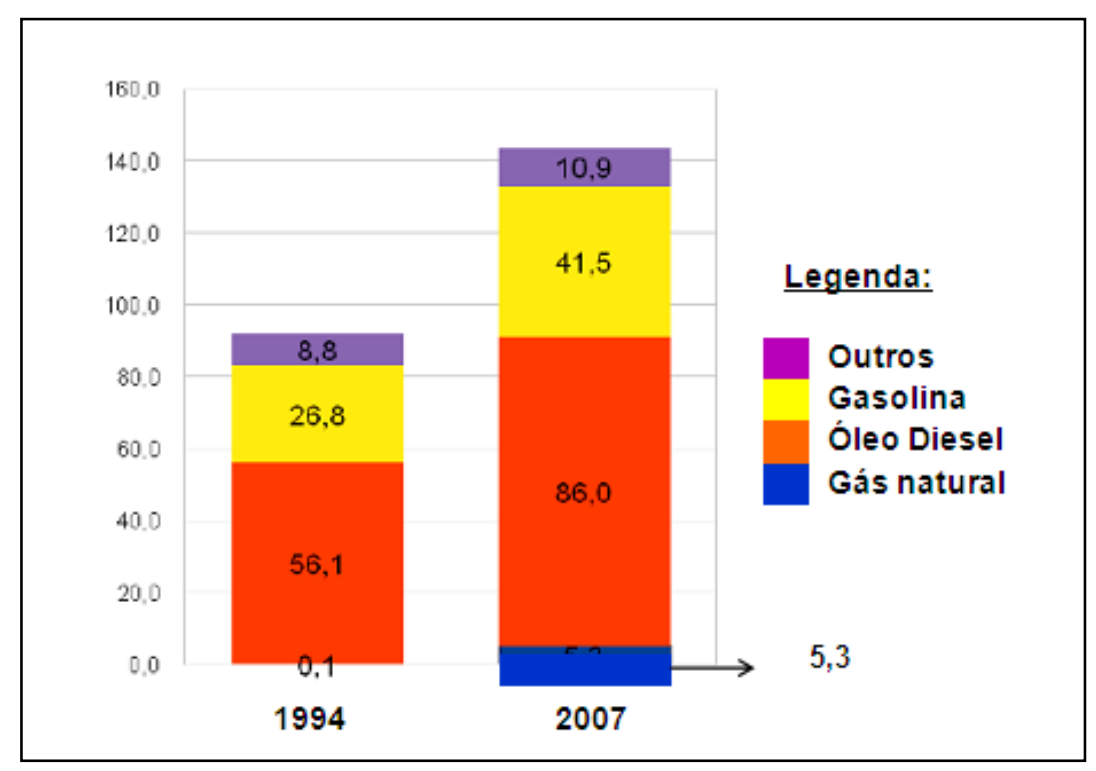

FIGURA 31 - Emissões de $\mathrm{CO}_{2}$ no setor de transportes rodoviários entre 1994 e 2007, em $10^{3} \mathrm{Gg}$ (milhões de toneladas). 
As emissões de $\mathrm{GEE}$, especialmente de $\mathrm{CO}_{2}$, resultantes de termelétricas, dependem fundamentalmente do seu tipo, do consumo de combustíveis e de particularidades em seu uso. A maioria dos compostos de carbono emitidos degrada-se, com o tempo, em $\mathrm{CO}_{2}$. De forma simplificada, apresentam-se na TAB. 19, os principais combustíveis usados em termelétricas e suas contribuições nessas emissões.

TABELA 19 - Estimativa de emissões de $\mathrm{CO}_{2}$ advindas de combustíveis fósseis no setor de termelétricas - 1994 e $2007^{210,213}$.

\begin{tabular}{cccccc}
\hline Termelétricas & $\begin{array}{c}\text { Emissões } \\
\mathbf{1 9 9 4} \\
(\mathbf{G g})\end{array}$ & $\begin{array}{c}\text { Participação } \\
\mathbf{1 9 9 4} \\
(\%)\end{array}$ & $\begin{array}{c}\text { Emissões } \\
\mathbf{2 0 0 7} \\
(\mathbf{G g})\end{array}$ & $\begin{array}{c}\text { Participação } \\
\mathbf{2 0 0 7} \\
(\%)\end{array}$ & $\begin{array}{c}\text { Variação } \\
\mathbf{1 9 9 4 - 2 0 0 7} \\
(\%)\end{array}$ \\
\hline Gás natural & 369,83 & 4 & $7.404,54$ & 31 & 1.902 \\
Carvão vapor & $4.356,31$ & 45 & $7.649,07$ & 32 & 76 \\
$\begin{array}{c}\text { Óleo diesel } \\
\text { Óleo }\end{array}$ & $2.060,12$ & 21 & $4.479,83$ & 19 & 117 \\
$\begin{array}{c}\text { combustível } \\
\text { Outros }\end{array}$ & $2.704,73$ & 28 & $4.043,17$ & 17 & 49 \\
\hline Total & 190,81 & 2 & 549,83 & 2 & 189 \\
\hline
\end{tabular}

Graficamente, esses dados podem ser mostrados como na FIG. $32^{210,213}$

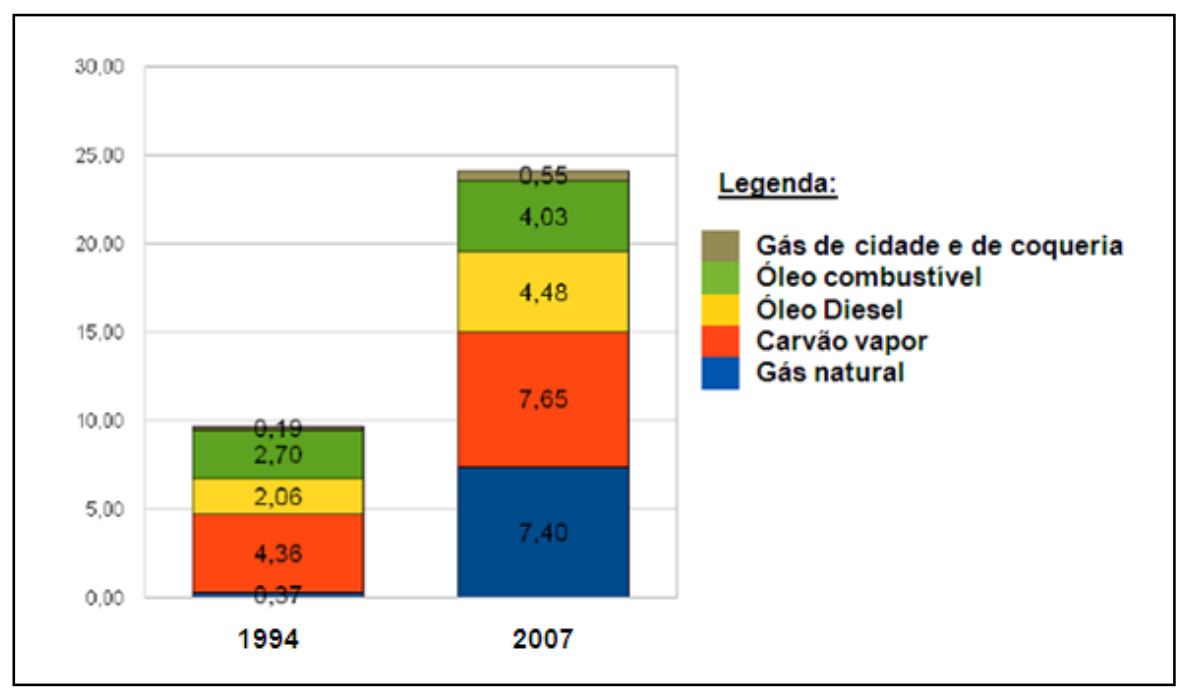

FIGURA 32 - Emissões de $\mathrm{CO}_{2}$ no setor de termelétricas de acordo com o tipo de combustível utilizado - $1994-2007$, em $10^{3} \mathrm{Gg}$ (milhões de toneladas). 
Em uma última, mas interessante análise revela-se que o balanço de carbono nas atividades energéticas do Brasil aponta que a intensidade das emissões de carbono no setor energético cresceu mais do que o Produto Interno Bruto (PIB), que é a soma das riquezas produzidas no país.

Um documento elaborado pelo MCT, que constitui mais uma das etapas na preparação do Segundo Inventário de Emissões, revela que, enquanto o PIB cresceu 2,4\% em média de 1995 até $2005^{214,215}$ as taxas de crescimento do setor de energia elétrica subiram, em média, no mesmo período $3,8 \%{ }^{216}$.

De acordo com estudo realizado pela API (American Petroleum Institute) isso significa que, em 2005, foram eliminadas na atmosfera cerca de $49.000 \mathrm{Gg}$ de dióxido de carbono ${ }^{217}$.

Concluindo-se: desse modo, o Brasil está chegando rapidamente aos padrões de emissões dos países desenvolvidos, segundo revelam os estudos apresentados e que comparam os dados de emissões de 1994 e 2007, numa prévia para o Segundo Inventário de Emissões, apontando-se como "vilões", a serem confirmados ao término do inventário, a indústria e a energia, que juntas deverão elevar o total de emissões de $\mathrm{CO}_{2}$ na atmosfera.

\section{13. A escala de Pacala e Socolow}

Sabe-se que a maioria dos GEE forma-se naturalmente, criando o efeito estufa natural, que possui um equilíbrio gasoso delicado. Mudanças nessas concentrações desestabilizam a sustentabilidade natural e trazem efeitos danosos ao ambiente.

Manter a sustentabilidade envolve a rapidez com que a natureza é capaz de reabsorver esses gases e, ao investirmos esforços para mitigar esses efeitos, evitamos um desequilíbrio climático.

$\mathrm{O} \mathrm{CO}_{2}$ é um dos GEE produzido mais velozmente pelas diferentes atividades humanas que buscam satisfazer às crescentes necessidades do modelo consumista atual e, de forma unânime, cientistas concordam que o aumento de sua concentração é um fato comprovado e causador do aquecimento global e das mudanças climáticas que a humanidade está enfrentando.

Medidas rápidas devem ser tomadas para sua redução como otimizar a energia, diminuir a queima de combustíveis fósseis e implantar fontes de energia renováveis como biomassa. 
Em alguns casos, essas implantações ainda são custosas, mas como qualquer regra de mercado, para o meio ambiente também se aplica a normativa do custo-benefício. Em virtude disso, maiores esforços financeiros e de pesquisa, que capturem e armazenem $\mathrm{CO}_{2}$, têm aumentado com relativa rapidez ${ }^{218}$.

Uma das melhores avaliações das possibilidades de iniciar, imediatamente os cortes nestas emissões, foi idealizada pela equipe liderada por Stephen Pacala e Robert Socolow.

Nela, os cientistas dividem o triângulo de estabilização obtido graficamente, como é mostrado na FIG. 33, em sete "cunhas" de remediação iguais.

Cada uma coloca em prática sete soluções tecnológicas que deverão conseguir evitar a emissão de $25 \mathrm{Gt} / \mathrm{C}$ no período de 2005 a $2050^{219,220}$.

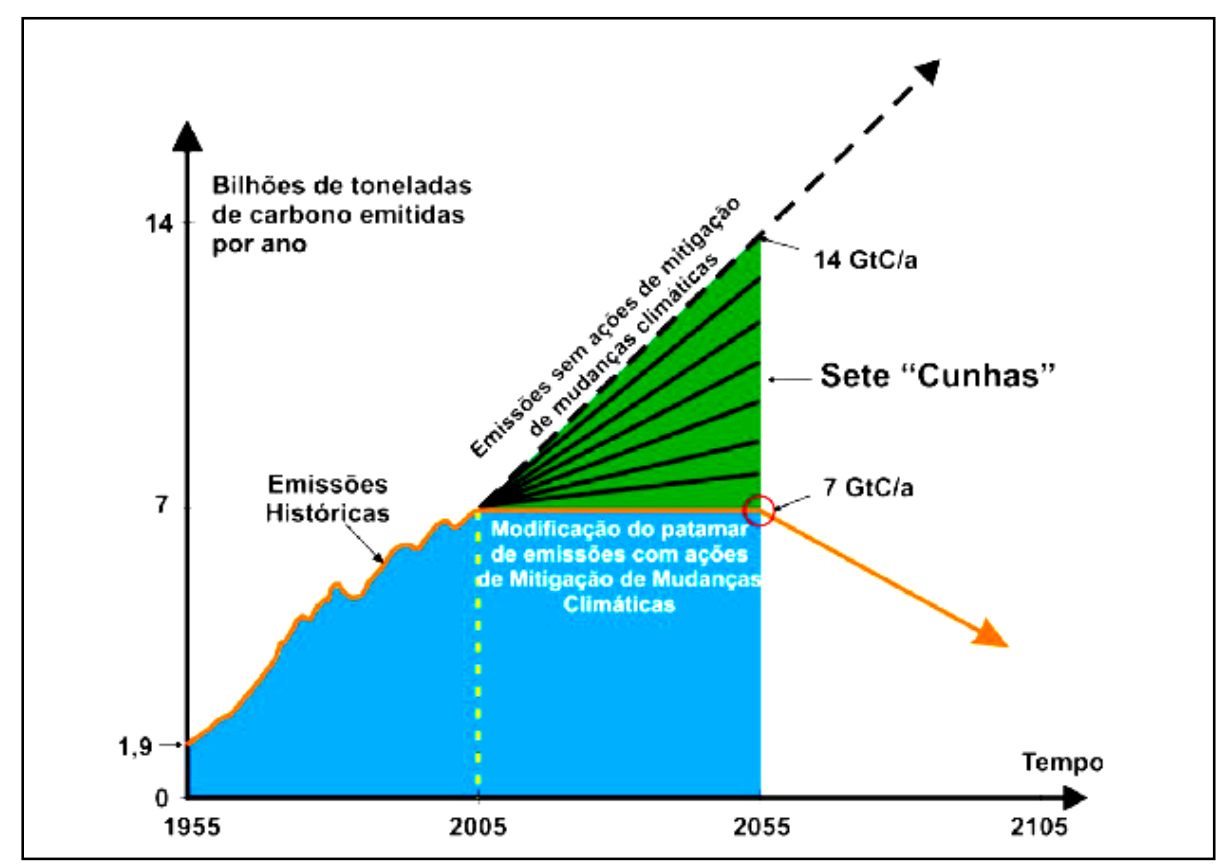

FIGURA 33 - As sete cunhas da escala de Pacala e Socolow ${ }^{219,220 .}$

Uma observação importante feita pelos dois pesquisadores, é que não se deve ficar abaixo das pretensões do Protocolo de Kyoto, ou seja, é importante manterem-se, e até reduzir, as emissões de $\mathrm{CO}_{2}$ que nele foram acordadas. 
Essas sete cunhas de remediação referem-se diretamente àquelas tecnologias que estão em estado avançado o bastante para já serem executadas, e também àquelas que estão em fase de pesquisa, podendo-se dividi-las em dois grupos: 221,222

i. Grupo de processos que não emitem ou emitem menos carbono para a atmosfera, cujas medidas relacionam-se a (ao):

1 - aumento da eficiência energética em geral;

2 - uso de combustíveis renováveis;

3 - descarbonização dos combustíveis fósseis;

4 - uso do hidrogênio;

5 - uso de energia nuclear;

ii. Grupo de captura e armazenamento de carbono advindo de processos industriais ou existentes na atmosfera, cujas medidas são:

6 - sequestro de carbono direto - pela captura e armazenamento de $\mathrm{CO}_{2}$ (CAC) ou Carbon Capture and Geological Storage (CCGS)

7 - sequestro de carbono indireto - via biomassa pela conservação de florestas e reflorestamento

Numa estratégia desenvolvida por Socolow e Pacala, dentro das sete cunhas de remediação, surgiu um desdobramento com quinze tecnologias que podem ajudar a preencher e cumprir estas sete cunhas correspondentes à diminuição das $25 \mathrm{Gt} / \mathrm{C}$ no período de 50 anos.

Cada um desses caminhos pode eliminar uma ou mais cunhas, aplicandose duas ou mais tecnologias que mitigarão os GEE e as alterações climáticas.

Na TAB. 20 apresentam-se esses desdobramentos das cunhas de Pacala e Socolow. 
TABELA 20 - Os quinze desdobramentos das "cunhas" de remediação de Pacala e Socolow ${ }^{222}$.

\begin{tabular}{|c|c|c|}
\hline Cunha & no & Esforços a serem empreendidos para alcançar as metas \\
\hline \multirow{3}{*}{$\begin{array}{l}\text { Medidas de } \\
\text { melhoria da } \\
\text { eficiência e da } \\
\text { conservação do } \\
\text { uso final da } \\
\text { energia }\end{array}$} & 01 & Reduzir a quilometragem anual de 16 mil km para 5 mil km. \\
\hline & 02 & $\begin{array}{l}\text { Aumentar a economia de combustíveis em } 2 \text { bilhões de } \\
\text { carros de } 13 \text { para } 26 \mathrm{~km} \text { por litro. }\end{array}$ \\
\hline & 03 & $\begin{array}{l}\text { Diminuir o consumo de eletricidade em lares, escritórios e } \\
\text { comércio em } 25 \% \text {. }\end{array}$ \\
\hline \multirow{2}{*}{$\begin{array}{l}\text { Medidas de } \\
\text { melhoria na } \\
\text { geração de } \\
\text { energia }\end{array}$} & 04 & $\begin{array}{l}\text { Aumentar de } 40 \% \text { a } 60 \% \text { a eficiência em } 1.600 \text { grandes } \\
\text { usinas a carvão (aquelas que geram } 1 \mathrm{GW} \text { ou mais). }\end{array}$ \\
\hline & 05 & Substituir 1.400 usinas de grande porte por centrais a gás. \\
\hline \multirow{3}{*}{$\begin{array}{c}\text { Medidas de } \\
\text { instalação de } \\
\text { CAC - captura e } \\
\text { armazenamento } \\
\text { de carbono }\end{array}$} & 06 & Instalação, no mínimo, em 800 grandes usinas a carvão. \\
\hline & 07 & $\begin{array}{l}\text { Instalação em usinas a carvão que produzam hidrogênio } \\
\text { para } 1,5 \text { bilhão de veículos. }\end{array}$ \\
\hline & 08 & $\begin{array}{l}\text { Instalação em usinas de conversão de carvão em gás de } \\
\text { síntese. }\end{array}$ \\
\hline \multirow{5}{*}{$\begin{array}{c}\text { Medidas de } \\
\text { implementação } \\
\text { do uso de fontes } \\
\text { alternativas de } \\
\text { energia }\end{array}$} & 09 & Dobrar a produção de energia nuclear substituindo o carvão. \\
\hline & 10 & $\begin{array}{l}\text { Implementar } 2 \text { bilhões de carros a álcool, usando um sexto } \\
\text { das terras mundiais cultiváveis. }\end{array}$ \\
\hline & 11 & $\begin{array}{l}\text { Aumentar a energia eólica em } 80 \text { vezes para produção de } \\
\text { hidrogênio automotivo. }\end{array}$ \\
\hline & 12 & $\begin{array}{l}\text { Aumentar em } 700 \text { vezes a geração de energia solar } \\
\text { substituindo aquela gerada por centrais a carvão. }\end{array}$ \\
\hline & 13 & $\begin{array}{l}\text { Aumentar em } 40 \text { vezes a geração de energia eólica para } \\
\text { substituir a da geração por centrais a carvão. }\end{array}$ \\
\hline \multirow{2}{*}{$\begin{array}{c}\text { Medidas de } \\
\text { proteção da } \\
\text { agricultura e } \\
\text { florestamento }\end{array}$} & 14 & $\begin{array}{l}\text { Expandir a preservação da agricultura com plantio direto } \\
\text { para } 100 \% \text { das terras aráveis. }\end{array}$ \\
\hline & 15 & Interromper de imediato todos os tipos de desflorestamento. \\
\hline
\end{tabular}


Pacala e Socolow advertem para as dificuldades de se colocar em prática cada uma das técnicas de remediação, mas insistem, e com razão, que todas e cada uma delas estão ao nosso alcance, sendo tecnologicamente possíveis.

Como conclusão de seu trabalho, ambos colocam que: ${ }^{219,220}$

i. é preciso uma conscientização imediata em escala planetária;

ii. deve-se decidir quais as tecnologias de remediação a ser adotadas;

iii. em uma primeira etapa serão necessários subsídios;

iv. no futuro, o mercado selecionará as melhores tecnologias;

v. as tecnologias de remediação não precisam ser, necessariamente, as mesmas para todos os países;

vi. deve-se avaliar continuamente os custos sociais e ambientais que cada tecnologia de remediação traz;

vii. é preciso estimar um prazo real para as emissões de carbono;

viii. as tecnologias de remediação envolvendo energias alternativas, reflorestamento e agricultura ecológica, demandarão uma grande ocupação dos solos;

ix. ainda estamos em tempo para atuar.

\section{14. Captura, sequestro e armazenamento de gás carbônico - CAC}

$\mathrm{O}$ ar atmosférico é composto por vários gases. Uma análise de ar seco e limpo ao nível do mar revela uma composição média de $21 \%$ de oxigênio, $78 \%$ de nitrogênio e $1 \%$ de outros gases, sendo que dentro desses $1 \%$, cerca de $0,03 \%$ é de dióxido de carbono ${ }^{223,224}$. O $\mathrm{CO}_{2}$ é um gás com baixa concentração, quer pode ser usado nas formas de sólido (gelo seco), líquido e gás em diversas aplicações industriais, tais como: carbonatação de bebidas, extintores de incêndio, soldagem e produção de compostos químicos, inclusive fertilizantes, borrachas vulcanizadas, espumas de poliuretano, entre outras ${ }^{225}$.

A captura, sequestro e armazenamento do $\mathrm{CO}_{2}$ (CAC) refere-se a uma série de mecanismos e procedimentos que permitem a separação desse gás das fontes produtoras e envolve seu transporte para um local de armazenamento e estocagem seguros e também seu isolamento por longos períodos, já que de outra forma ele seria emitido para a atmosfera ou nela permaneceria. Todos esses mecanismos foram desenvolvidos pelo homem objetivando diminuir as emissões de GEE ${ }^{226}$. 
Uma aplicação importante dos procedimentos que envolvem o CAC é aquela que utilize a biomassa como fonte de energia na substituição de combustíveis poluentes. Isso torna o CAC mais eficaz na mitigação, dando lugar às chamadas "emissões negativas", pois na captura e armazenamento do $\mathrm{CO}_{2}$ atmosférico ele estará "estocado e armazenado" por essa biomassa.

Existem, atualmente, boas opções de mitigação dos GEE que já poderiam e deveriam estar em ação, e outras como o uso da energia nuclear, o aperfeiçoamento dos sumidouros biológicos e a redução das emissões dos outros $\mathrm{GEE}$, além do próprio $\mathrm{CO}_{2}$ que deveriam ser mais pesquisadas e estudadas ${ }^{218}$.

Porém, a aplicação do CAC ainda é muito dispendiosa e depende de ajustes importantes como o contínuo desenvolvimento tecnológico, do quanto isso custará, da transferência de tecnologias aos países em desenvolvimento, dos aspectos burocráticos e normativos de cada região ou país, das questões ambientais e da percepção pública ${ }^{218,226}$.

Independentemente de todos esses fatores, é sabido e notório que nenhuma opção tecnológica proporcionará, sozinha, as reduções de emissões necessárias para uma estabilização dos GEE.

De modo geral, $0 \mathrm{CO}_{2}$ pode ser armazenado na biosfera através da biomassa, na hidrosfera através do armazenamento oceânico e na litosfera, pelo armazenamento geológico ${ }^{227}$. Cada uma delas foi agrupada em dois tipos de sequestro de carbono - o sequestro de carbono indireto e o direto: ${ }^{228,226}$

\section{14. 1. Sequestro de carbono indireto ou terrestre - CAC indireto}

No CAC indireto ou terrestre, há a fixação de carbono na biomassa, que o "captura" na vegetação e no solo, pela remoção de $\mathrm{CO}_{2}$ da atmosfera ou pela prevenção de emissão de $\mathrm{CO}_{2}$ nesses ecossistemas. Os principais mecanismos que o realizam são o(a): ${ }^{226}$

i. aumento da fixação fotossintética de carbono quando o processo de fotossíntese é mais intenso que os processos de respiração e decomposição, resultando no crescimento do vegetal;

ii. redução da decomposição da matéria orgânica nos solos, aumentando a biomassa microbiana do solo;

iii. melhoria das formas de manejo da terra. 
Os solos são o maior reservatório de carbono dos ecossistemas terrestres e cerca de $75 \%$ dessa quantidade é neles estocada. Percebe-se, então, que além de serem essenciais para o desenvolvimento do vegetal, os solos são de grande importância no sequestro indireto de carbono. Este mecanismo do CAC acaba por incentivar os florestamentos e reflorestamentos ${ }^{226,229}$.

\section{14. 2. Sequestro de carbono direto - CAC direto}

O CAC direto envolve o armazenamento oceânico (na hidrosfera) e o armazenamento geológico (na litosfera), através dos já citados processos de separação e captura do $\mathrm{CO}_{2}$ direto das fontes emissoras antes que ele alcance a atmosfera, seguido de seu transporte para um local de estocagem e de seu armazenamento de forma segura.

As técnicas usadas no CAC direto devem ser rentáveis e competitivas quanto aos custos, além de ser aceitáveis quanto à segurança e aos potenciais efeitos ambientais. Deve-se considerar que: ${ }^{218,227,229}$

i. o processo de armazenamento de $\mathrm{CO}_{2}$ necessita ser menos prejudicial ao ambiente que a liberação contínua do gás;

ii. o período de armazenamento deve ser longo, preferencialmente de centenas a milhares de anos;

iii. o risco de acidentes deve ser minimizado;

iv. o tipo de armazenamento não deve violar quaisquer leis ou regulamentos nacionais ou internacionais.

Os caminhos ideais do CAC direto são aqueles que oferecem as maiores capacidades de armazenamento aliadas aos baixos custos.

A existência de reservatórios naturais prova que, sob circunstâncias favoráveis, o CAC direto pode servir por centenas de anos ou mais.

Antes de se iniciar um procedimento que habilite o uso do CAC direto, devem ser seguidas algumas etapas fundamentais, como as que se encontram indicadas na FIG. $34{ }^{230,232,233,235,236,237}$. 
1. Sequestro e separação do $\mathrm{CO}_{2}$

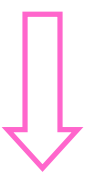

2. Compressão do $\mathrm{CO}_{2}$

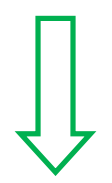

3. Transporte do $\mathrm{CO}_{2}$<smiles>CCCCCCCCC</smiles>

4. Armazenamento do $\mathrm{CO}_{2}$

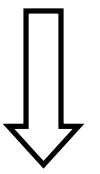

5. Verificação e monitoramento
É a separação dos gases provenientes de fontes estacionárias, que geralmente estão misturados entre si, sendo que há $\mathrm{CO}_{2}$ em pouca concentração. Essas fontes são, por exemplo, cimenteiras, plantas de energia (carvão, gás natural, óleo), refinarias, campos de exploração e produção de óleo e gás, locais de separação de $\mathrm{CO}_{2}$, unidades de produção de gás natural e destilarias de álcool.

Após a captura, $\mathrm{o} \mathrm{CO}_{2}$ deve ser comprimido até atingir uma pressão de cerca de 100 atm. Essa etapa não é básica, mas é necessária e deve ser feita antes da etapa de transporte.

Comercialmente o transporte de $\mathrm{CO}_{2}$ é feito por meio de gasodutos ou carbodutos (dutos on e offshore), navios e combinações dos dois meios de transporte. Também pode ser transportado em tanques sobre ferrovias e rodovias, mas não são opções atraentes devido ao alto custo.

Feito de duas formas - oceânica e geológica - com técnicas específicas em locais propícios como recuperação avançada de poços de óleo (RAP); camadas de carvão; reservatórios exauridos de óleo e gás; aquíferos profundos; recuperação avançada de poços de gás (RAG) e domos de sal.

Para que haja sucesso das técnicas de sequestro de carbono, projetos são desenvolvidos, calculando e medindo a quantidade de $\mathrm{CO}_{2}$ que será armazenada ao longo dos anos. São as técnicas de monitoramento e verificação do armazenamento.

FIGURA 34 - Principais etapas que devem ser seguidas durante o processo de CAC direto. 
A primeira etapa do processo de sequestro e separação do $\mathrm{CO}_{2}$ é uma das mais importantes e envolve rotas tecnológicas nessa captura.

Estas rotas são classificadas em diferentes processos, cada um deles relacionados a uma dessas tecnologias, que podem ser seguidas conforme as necessidades e interesses da empresa que as utilizar.

Essas tecnologias são: ${ }^{234,238,239}$.

i. Pós-combustão - consiste na remoção do $\mathrm{CO}_{2}$ depois da queima de combustíveis fósseis, sistema ideal para a aplicação em centrais termoelétricas. Esta tecnologia é o primeiro passo para a captura de $\mathrm{CO}_{2}$ em larga escala, sendo já economicamente viável;

ii. Pré-combustão - consiste em retirar o $\mathrm{CO}_{2}$ dos combustíveis antes da queima. Esta tecnologia já é aplicada na fabricação de fertilizantes e na produção de hidrogênio. Apesar do processo inicial de retirar o carbono antes da combustão ser mais complexo e caro, as concentrações mais altas de $\mathrm{CO}_{2}$ e a pressão mais elevada facilitam sua separação;

iii. Oxi-combustão - este processo requer uma separação prévia do oxigênio do ar para se obter um gás com uma pureza de 95 a 99\%. $O$ desafio é como separar o oxigênio do resto do ar. As estratégias são semelhantes àquelas usadas para separar $\mathrm{CO}_{2} . \mathrm{O}$ ar pode ser arrefecido, para que o oxigênio se liquefaça. A aplicação deste sistema em caldeiras está atualmente em fase de demonstração e o seu uso em sistemas de turbinas a gás ainda está em fase de investigação;

iv. Processos industriais - onde $\mathrm{O}_{\mathrm{CO}_{2}}$ é extraído dos gases de exaustão através de técnicas como absorção ou por membranas de separação.

Na FIG. 35 é mostrado, de forma simplificada, como essas diferentes tecnologias entrelaçam-se nessa primeira etapa de captura de $\mathrm{CO}_{2}{ }^{227,240}$. 


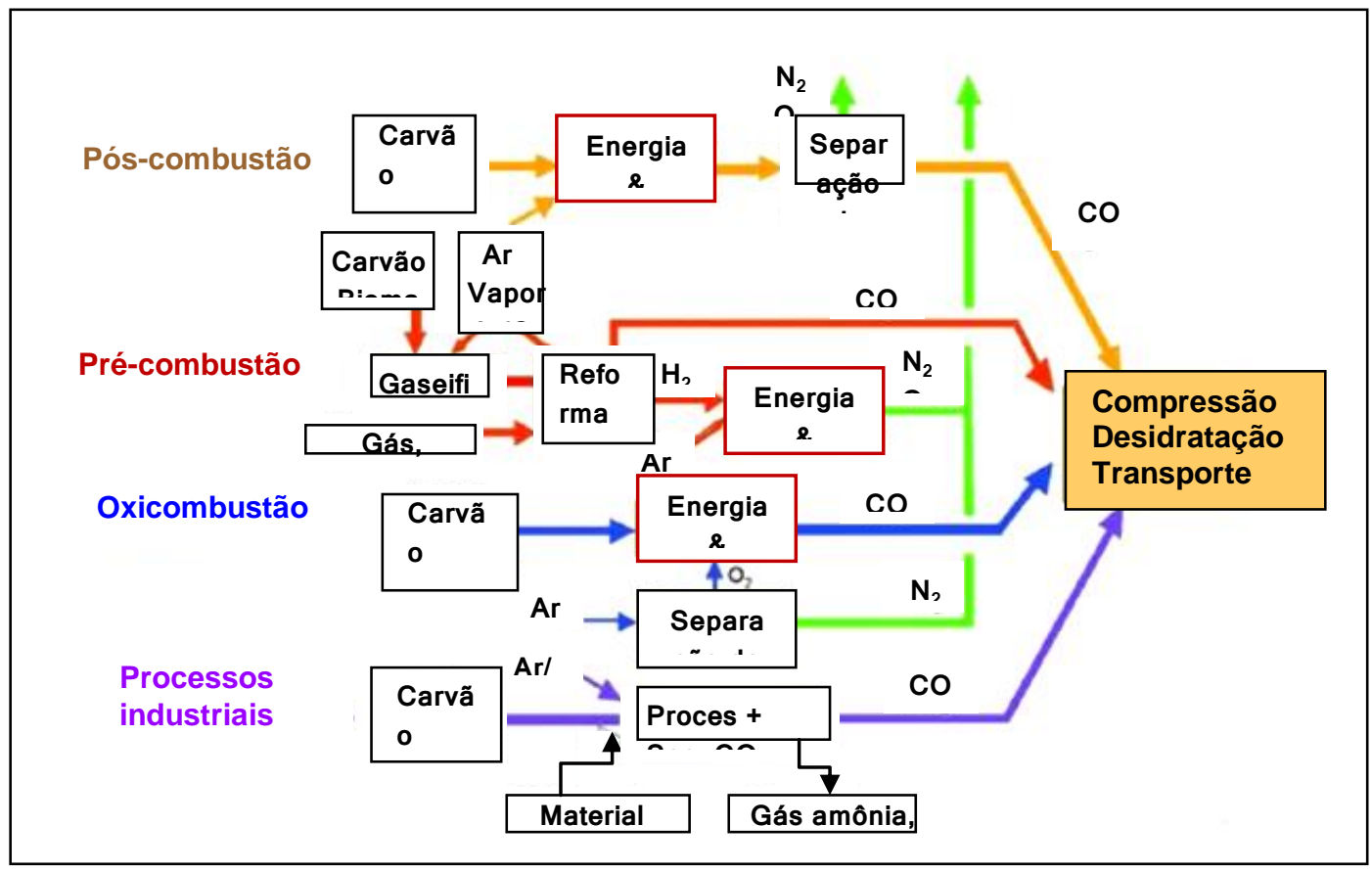

FIGURA 35 - Síntese simplificada dos principais processos e sistemas envolvidos na captura e separação do $\mathrm{CO}_{2}$.

As próximas etapas, indicadas como de números dois a cinco, na figura 34 da página 118 anterior, podem ser graficamente demonstradas na FIG. 36 a seguir: ${ }^{241}$

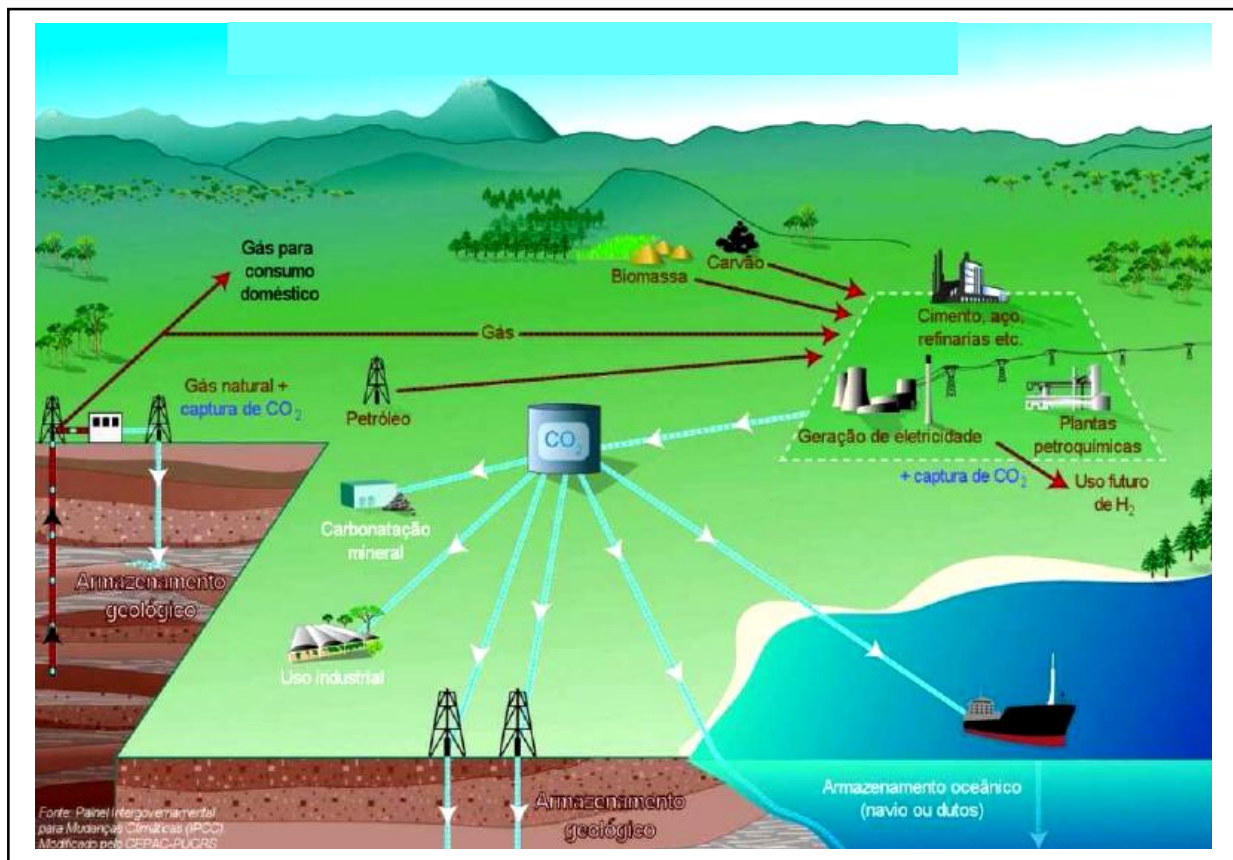

FIGURA 36 - Principais sistemas de CAC, as fontes nas quais se pode usá-lo e as opções para seu transporte e armazenamento. 
Nas FIG. 37 e 38, é mostrado de forma ilustrativa, respectivamente, o armazenamento geológico e oceânico de $\mathrm{CO}_{2}$ (CAC direto)

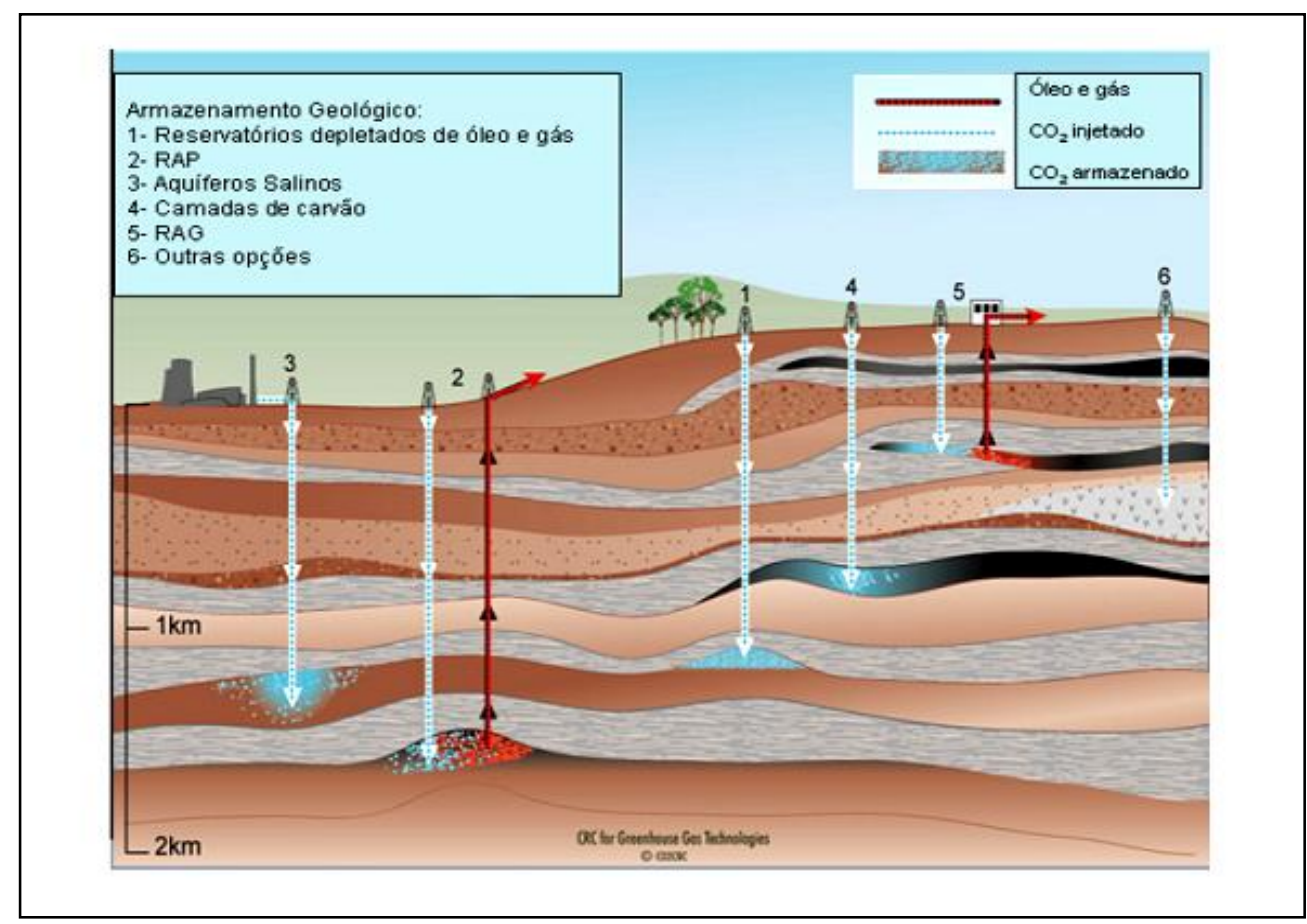

FIGURA 37 - Opções para o armazenamento geológico de $\mathrm{CO}_{2}{ }^{241}$.

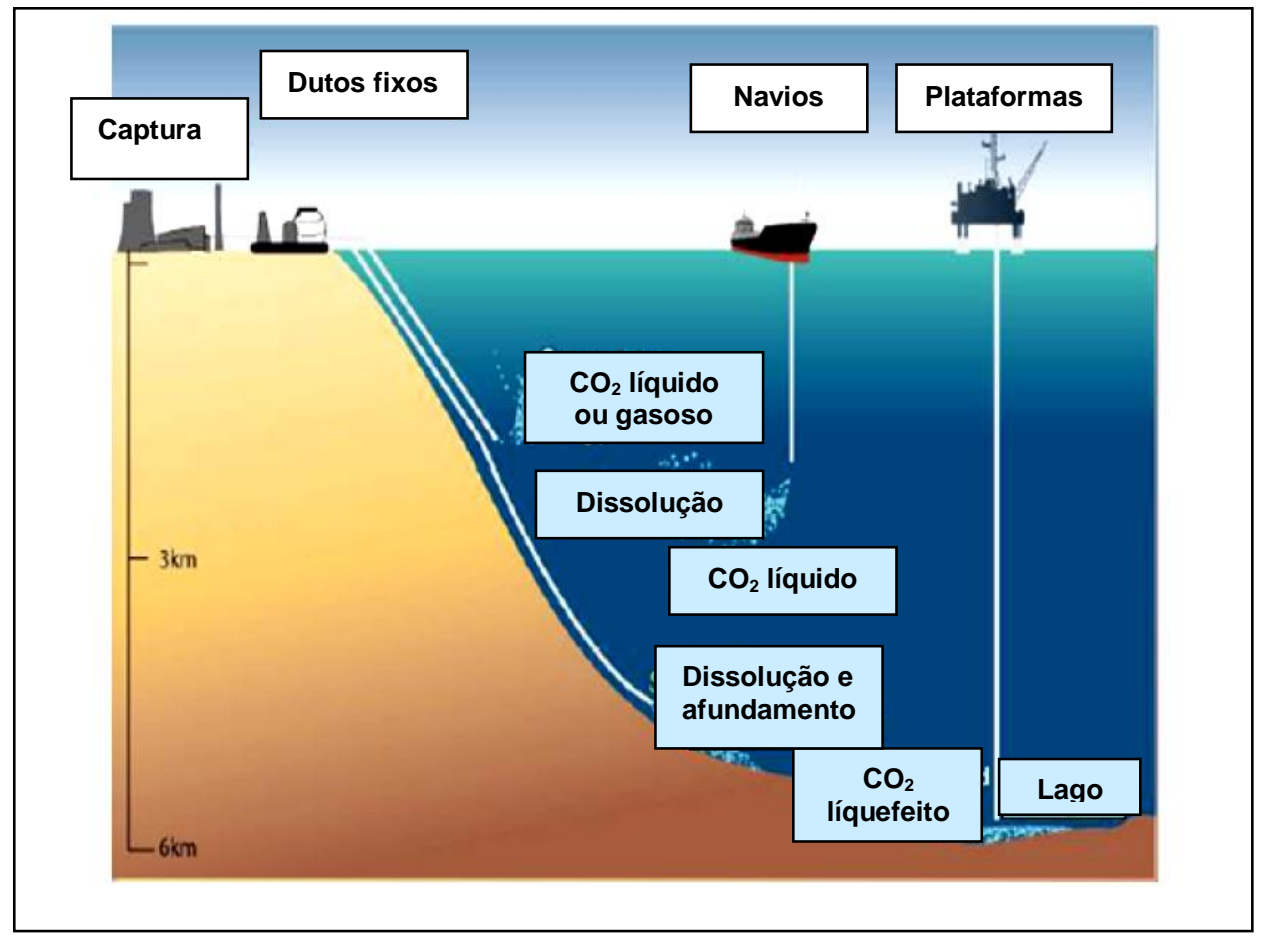

FIGURA 38 - Opções para o armazenamento oceânico de $\mathrm{CO}_{2}{ }^{242}$. 


\section{14. 3. A carbonatação mineral do $\mathrm{CO}_{2}$}

Muitas formas de vida aquática, seja de água doce ou salgada, extraem carbono e oxigênio da água e os combinam com cálcio para produzir carbonato de cálcio $\left(\mathrm{CaCO}_{3}\right)$. Essa substância, usada para formar conchas e outras partes duras do corpo, por uma variedade de organismos, como corais, moluscos, ostras e algumas plantas e animais microscópicos é levada para o fundo desses reservatórios aquáticos quando esses organismos morrem ${ }^{31}$.

Ao longo de milhões de anos, mais organismos mortos criam mais dessas camadas ricas em carbonatos. Esses depósitos permanecem enterrados e, além de receberem os carbonatos, também recebem areia e/ou lama, criando calor e uma pressão que acaba por mudá-los física e quimicamente, transformando-os em rochas sedimentares, como calcário, mármore e cal. Eventualmente esses depósitos afloram à superfície, formando montanhas e solos ${ }^{243}$.

Rochas sedimentares possuem em sua composição, altas concentrações de sais dissolvidos em água quando estão na superfície terrestre, formando nosso solo, ou em reservatórios aquáticos, como os aquíferos, por exemplo, (profundos ou não) e têm um alto potencial para a aplicação dos procedimentos CAC ${ }^{234}$.

Esses locais, que são abundantes em todo o planeta, permitem, então, a captura e sequestro do $\mathrm{CO}_{2}{ }^{226}$.

Uma das características do $\mathrm{CO}_{2}$ é sua solubilidade em água. Nos solos, por exemplo, uma parte desse gás que ali for injetada, acabará reagindo com os minerais presentes no local, formando compostos sólidos estáveis como os carbonatos, que se depositam e armazenam permanentemente o $\mathrm{CO}_{2}{ }^{243}$.

Essa seria a carbonatação mineral, que ocorre pelas interações do meio líquido (água) com fragmentos de rochas enriquecidas por sais, como por exemplo, cálcio, magnésio e ferro. Esses sais reagem em presença do $\mathrm{CO}_{2} \mathrm{e}$ acabam por formar os carbonatos.

A carbonatação mineral oferece, ao menos, duas grandes vantagens: a estabilidade do $\mathrm{CO}_{2}$ capturado por um longo período de tempo e a grande capacidade de armazenamento, já que a matéria-prima utilizada para o processo são os sais, disponíveis em grande quantidade em todo o planeta ${ }^{244}$.

No caso dos aquíferos, essa injeção deve ser feita, preferencialmente em profundidades superiores a 800 metros, assim, devido à pressão no reservatório, 
este gás, mais leve, sobe para o topo desse reservatório e acaba por aderir à sua superfície, ali permanecendo ${ }^{227}$.

Deve-se considerar nesses casos, que os locais a serem escolhidos, precisam estar o mais distante possível de centros com altas concentrações populacionais, mas também, o mais próximo possível das fontes emissoras do dióxido de carbono, para que o custo com seu transporte através de dutos, por exemplo, seja minimizado ${ }^{245,246}$.

\section{14. 4. Os custos do CAC direto}

Segundo o IPCC, de $20 \%$ a $40 \%$ das emissões globais de $\mathrm{CO}_{2}$ advindas de combustíveis fósseis podem ser tecnicamente adaptados para armazenamento até 2050 . Até 2100 , calcula a organização, de 220 bilhões $\left(220 \times 10^{3} \mathrm{Gt}\right)$ a 2,2 trilhões de toneladas $\left(2,2 \times 10^{6} \mathrm{Gt}\right)$ de $\mathrm{CO}_{2}$ poderão ser estocados na crosta terrestre, abrangendo de $15 \%$ a $55 \%$ da poluição mundial até o fim do século ${ }^{227}$.

Atualmente, todas as etapas do CAC são altamente custosas e, portanto, ainda economicamente inviáveis.

Segundo palavras do geólogo australiano John Bradshaw, chefe-executivo do Greenhouse Gas Storage Solutions (GGSS) e um dos cientistas do Painel Intergovernamental sobre Mudanças Climáticas (IPCC): ${ }^{247}$

"A captura e a compressão do $\mathrm{CO}_{2}$ respondem por $60 \%$ dos custos, $\mathrm{O}$ transporte e a injeção, 40\%. Novos estudos estão sendo feitos a fim de reduzir esses custos. É caro, mas os governos, empresas públicas $e$ privadas e até mesmo as pessoas comuns precisam definir metas. A questão é decidir se queremos pagar por nossos atos agora ou depois."

A escolha de reservatórios para armazenamento de $\mathrm{CO}_{2}$ também deve ser criteriosa. Programas de monitoramento e métodos de remediação e verificação exigem, além de como saber estancar possíveis vazamentos, um conhecimento detalhado do comportamento do $\mathrm{CO}_{2}$ em cada formação geológica - como as propriedades dos materiais que os compõem, permeabilidade, deformabilidade, resistência, heterogeneidade ${ }^{231,244}$.

Vários dos procedimentos que envolvem essas tecnologias estão em fases avançadas de desenvolvimento e investigação e, apesar dos custos ainda altos, 
há um empenho cada vez maior, por parte de cientistas, institutos e universidades, para a melhoria nessas tecnologias, visando à diminuição desses valores e a sua rápida aplicação.

Os custos por tonelada de $\mathrm{CO}_{2}$ evitado pelos procedimentos CAC variam substancialmente, pois dependem do tipo de instalação que envolve sua implantação, bem como do tipo de tecnologia que for utilizada no sistema CAC escolhido. Na TAB. 21 apresentam-se os valores estimados nesse processo.

TABELA 21 - Custos estimados nas várias etapas que envolvem os sistemas de captura e armazenamento de $\mathrm{CO}_{2}$ direto - CAC direto ${ }^{248,249}$.

\begin{tabular}{|c|c|c|}
\hline Componente do CAC & $\begin{array}{c}\text { Custo estimado } \\
\text { em US } \$ / \mathrm{t} \mathrm{OO}_{2} \\
\text { capturado }\end{array}$ & $\begin{array}{c}\text { Custo estimado em } \\
\mathrm{R} \$ / \mathrm{t} \mathrm{CO}_{2} \\
\text { capturado }\end{array}$ \\
\hline $\begin{array}{l}\text { Captura do } \mathrm{CO}_{2} \text { emitido } \\
\text { numa central elétrica a gás }\end{array}$ & de 15 a 75 & de 26,685 a 133,424 \\
\hline $\begin{array}{l}\text { Captura do } \mathrm{CO}_{2} \text { emitido na } \\
\text { produção de } \mathrm{H}_{2} \text { (do } \mathrm{GN} \text { ) }\end{array}$ & de 5 a 55 & de 8,895 a 97,845 \\
\hline $\begin{array}{l}\text { Captura do } \mathrm{CO}_{2} \text { emitido por } \\
\text { outras fontes industriais }\end{array}$ & de 25 a 115 & de 44,474 a 204,584 \\
\hline Transporte & de 1 a 8 & de 1,779 a 14,232 \\
\hline Armazenamento geológico & de 0,5 a 8 & de 0,889 a14,232 \\
\hline $\begin{array}{l}\text { Armazenamento geológico: } \\
\text { vigilância e verificação }\end{array}$ & de 0,1 a 0,3 & de 0,177 a 0,533 \\
\hline Armazenamento oceânico & de 5 a 30 & de 8,895 a 53,37 \\
\hline Carbonatação mineral & de 50 a 100 & de 88,949 a 177,899 \\
\hline TOTAL & $\begin{array}{c}\text { de U\$101,6 a } \\
\text { U\$391,3 }\end{array}$ & $\begin{array}{c}\text { de } R \$ 180,743 a \\
R \$ 681,887\end{array}$ \\
\hline
\end{tabular}

Legenda: Cotação do dólar comercial em 04/10/2009- U\$1,0 = R\$1,799 250 . 


\section{15. Uma das energias renováveis - a biomassa}

A energia é o fenômeno resultante do processo que permitiu o desenvolvimento das civilizações na produção de alimentos, no lazer, na aquisição de bens de consumo, no desenvolvimento econômico, social e cultural. Sua produção é a mais intensa dentre as atividades da sociedade e a que possui maior poder de degradação do ambiente, seja na emissão de poluentes, ou na exploração intensiva de recursos naturais não renováveis, que trazem consigo problemas ambientais.

Esse é um dos principais motivos que tem levado as fontes alternativas de energia a ganhar espaço, visto que são menos agressivas, estando a biomassa dentre aquelas que mais desperta interesse.

Energia renovável é aquela obtida de fontes naturais capazes de se regenerar, e portanto virtualmente inesgotáveis, ao contrário dos recursos nãorenováveis. Citam-se, por exemplo, a energia solar, a hidrelétrica, a eólica e aquela que é o foco deste trabalho, a energia da biomassa ${ }^{30,251}$.

As energias renováveis são consideradas como "energias alternativas" ao modelo energético tradicional, tanto pela sua disponibilidade (presente e futura) garantida (diferente dos combustíveis fósseis) como pelo seu menor impacto ambiental $^{252}$.

As pesquisas brasileiras no setor de energias alternativas desenvolveramse com o propósito de diversificar nossa matriz energética, buscando diminuir a dependência de combustíveis fósseis e contribuindo com a redução das emissões de gases de efeito estufa.

Nesse sentido, como proposto neste trabalho, a utilização dos resíduos da biomassa no processo da gaseificação permite um melhor controle da quantidade do $\mathrm{CO}_{2}$ emitido, visto que esse gás é o que se deseja sequestrar na formação de um fertilizante e, concomitantemente na geração de créditos de carbono.

O Brasil é um dos países que possui o melhor aproveitamento da fonte renovável de biomassa, seja em ciclos curtos, como o da cana-de-açúcar, seja em ciclos longos como em florestas ${ }^{253}$.

Apesar de o país estar tentando assumir uma posição positiva na implantação de tecnologias que utilizem as fontes renováveis como um todo, pode-se dizer que, até o momento, somente a biomassa tem se destacado, 
citando-se como exemplo marcante, o caso da cadeia produtiva do etanol, reconhecida como uma das mais eficientes do mundo.

A importância dessa energia na matriz brasileira exige uma definição de objetivos estratégicos nacionais de médio e longo prazos e, para sua efetivação considera-se que a biomassa é composta por quatro grandes grupos: ${ }^{42,254}$

i. etanol e co-geração de energia provenientes da cana-de-açúcar;

ii. biodiesel de fontes lipídicas (animais e vegetais);

iii. biomassa florestal e resíduos;

iv. dejetos agropecuários e da agroindústria

Na FIG. 39 é mostrado um diagrama que identifica a importância da biomassa, essa fonte de energia renovável, no cenário brasileiro e mundial ${ }^{42,255}$.

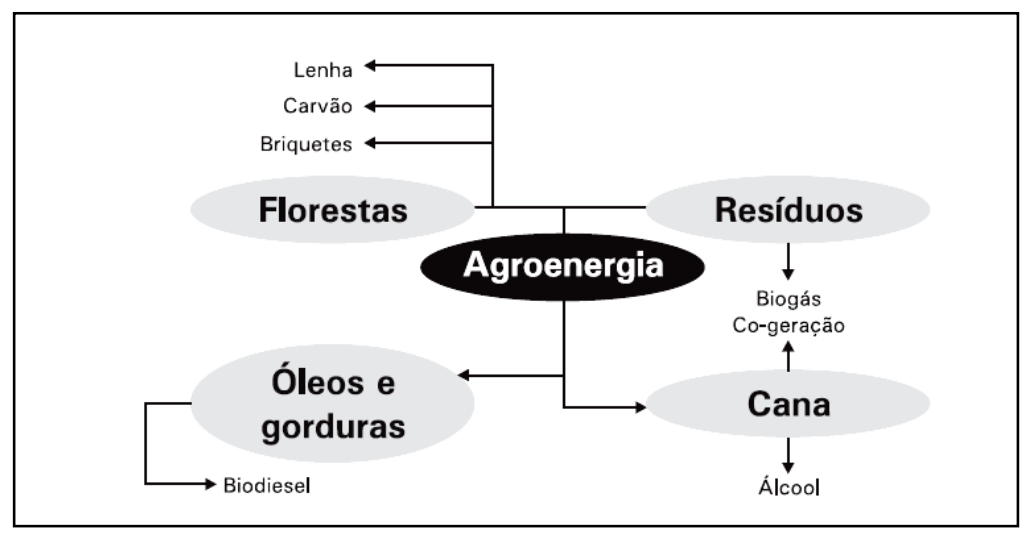

FIGURA 39 - Biomassa, uma matriz energética renovável e as variantes que dela podem se originar, produzindo formas secundárias de energia ${ }^{42}$.

Para cada componente do complexo sistema de energias renováveis, diferentes desafios são impostos servindo como indutores de prioridades de pesquisa. Para a energia renovável de biomassa, pode-se citar: ${ }^{42,253,256}$

i. o desenvolvimento de tecnologias para o aproveitamento energético de resíduos das produções agrícola, pecuária e florestal e da agroindústria; 
ii. o desenvolvimento de tecnologias para a utilização de compostos orgânicos resultantes da produção agropecuária, com risco sanitário, na produção de energia;

iii. a interface com as redes de pesquisa no aproveitamento de esgotos urbanos para fins energéticos;

iv. o enfrentamento dos desafios tecnológicos para incrementar essa fonte de energia renovável no cenário brasileiro.

O cenário de referência do World Energy Outlook (WEO) projeta que a demanda por energias renováveis crescerá em 2,3\%, ao ano, nas duas próximas décadas, portanto, acima do crescimento médio da demanda geral ${ }^{189}$.

A biomassa, por sua disponibilidade, parece ser a maior e mais sustentável fonte de energia renovável pronta para uso e nos países em desenvolvimento, a energia dela advinda, continuará a ser importante fonte na matriz energética ${ }^{257}$.

Na FIG. 40 estão indicadas as fontes de energia renováveis conhecidas até a atualidade ${ }^{87,258}$.

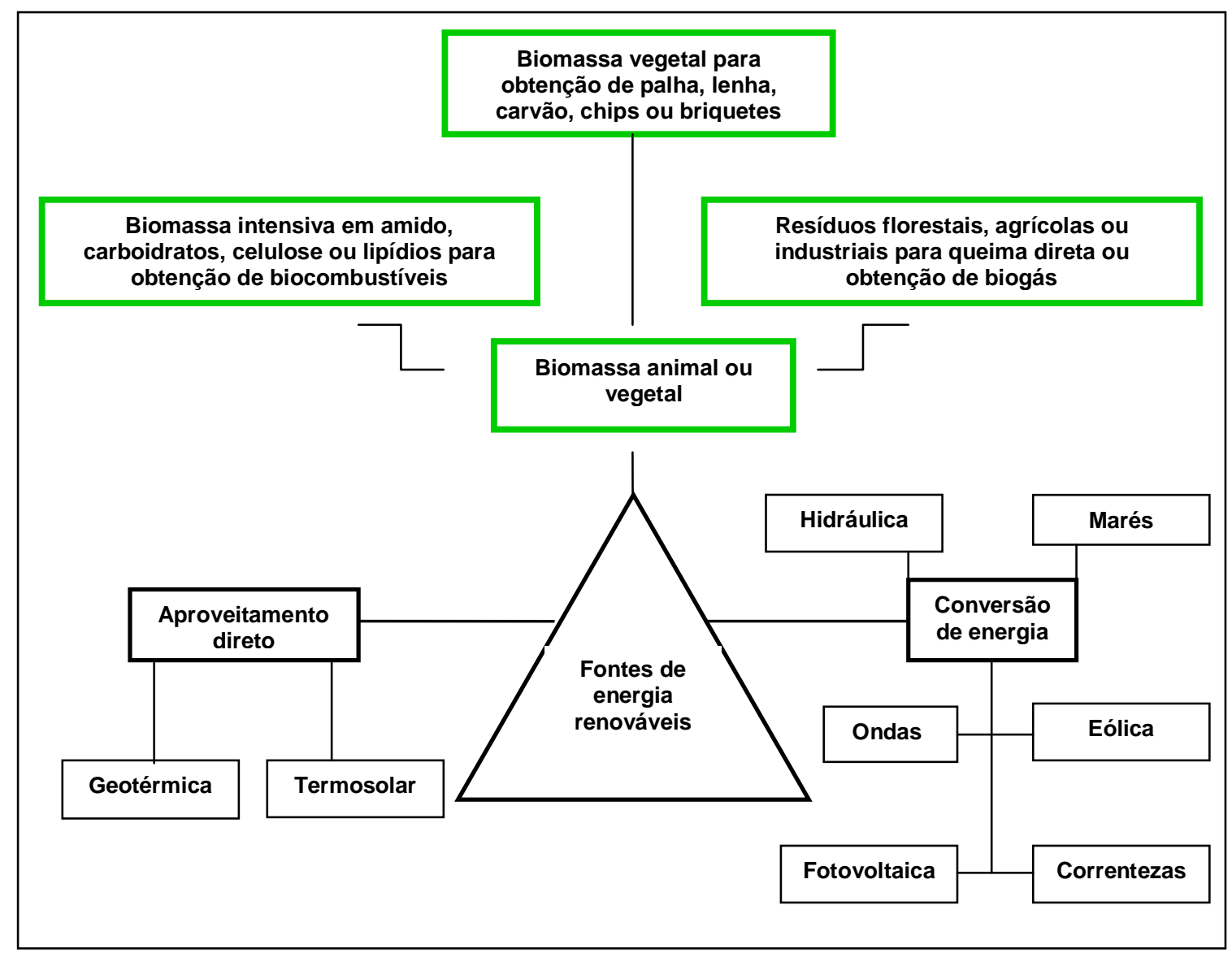

FIGURA 40 - As fontes de energia renováveis. 


\section{15. 1. Conversão da biomassa}

A biomassa pode se utilizada como fonte de calor e geração de eletricidade a partir de sua combustão em fornos e caldeiras. A conversão da biomassa, processo denominado gaseificação, permite a utilização de motores e turbinas em aplicações de geração de eletricidade, o que constitui um potencial técnico para aumento da eficiência de conversão ${ }^{259,260}$.

Existem duas rotas possíveis de conversão da biomassa:

i. a rota termoquímica - representada pela pirólise e/ou gaseificação da biomassa, passando pela obtenção de gás de síntese;

ii. a rota bioquímica - representada pela hidrólise e fermentação da biomassa, que ainda apresenta sérios desafios tecnológicos

Os dois processos são mostrados na FIG. 41 a seguir: ${ }^{261}$

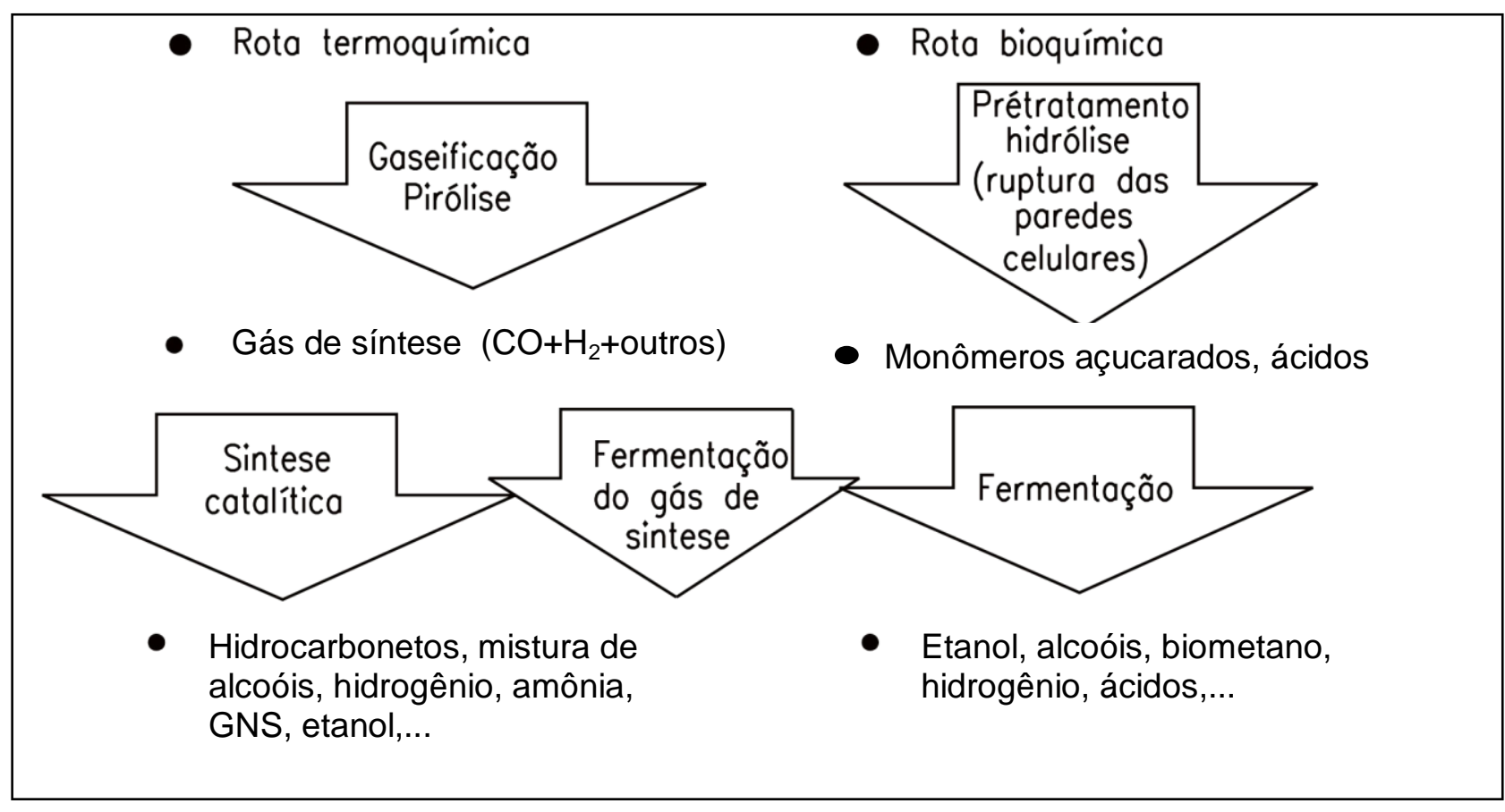

FIGURA 41 - Rotas de conversão da biomassa. 


\section{16. Gaseificação}

\section{16. 1. A tecnologia da gaseificação}

Uma das definições de gaseificação, encontrada na literatura ${ }^{262}$ explica que é um processo onde há conversão termo-química parcial, de materiais com carbono, como a biomassa, através de sua combustão parcial, em presença de um agente oxidante. Assim, um combustível sólido, é convertido em uma mistura gasosa combustível ou gás de síntese, com baixo/médio poder calorífico ${ }^{263}$.

A combustão parcial ocorre quando o ar, ou mais precisamente o oxigênio, está em quantidade abaixo da condição estequiométrica ao que seria necessário para uma queima completa da biomassa. Os principais compostos formados nesse processo são monóxido de carbono $(\mathrm{CO})$, dióxido de carbono $\left(\mathrm{CO}_{2}\right)$, hidrogênio $\left(\mathrm{H}_{2}\right)$, metano $\left(\mathrm{CH}_{4}\right)$ e o nitrogênio $\left(\mathrm{N}_{2}\right)^{260,264,265,266}$.

O processo de gaseificação da biomassa ocorre em equipamentos denominados gaseificadores e resulta de diversas reações que ocorrem em diferentes etapas como apresentado na FIG. 42.

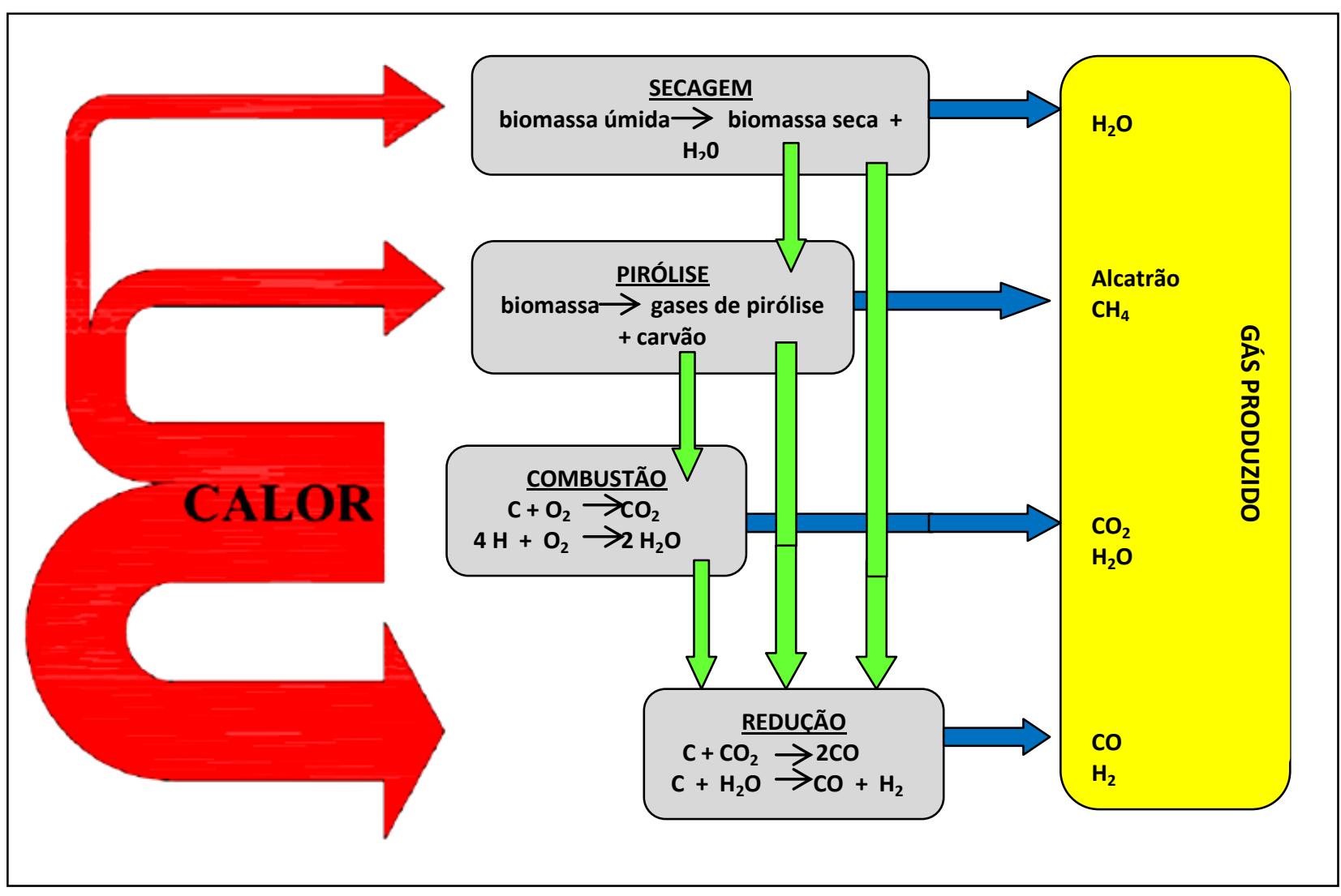

FIGURA 42 - Esquema das principais etapas do processo de gaseificação e alguns dos produtos que nele são formados ${ }^{267}$. 


\section{16. 2. As etapas da gaseificação}

Nos gaseificadores, o gás proveniente da biomassa passa, basicamente, por quatro etapas: ${ }^{266,268,269,273}$

i. Secagem - a retirada da umidade pode ser feita quando a biomassa é introduzida no gaseificador, aproveitando-se a temperatura ali existente, pois a operação com ela seca é mais eficiente;

ii. Pirólise - que acontece numa zona do reator onde há a degradação térmica da biomassa na ausência de oxigênio. Esta é então convertida em alcatrão, voláteis e sólidos (carvão);

iii. Combustão - onde o carbono da biomassa reage com oxigênio do ar produzindo dióxido de carbono $\left(\mathrm{CO}_{2}\right)$ e vapor, liberado energia em uma reação exotérmica;

iv. Redução - consiste numa reação endotérmica onde ocorre a formação, principalmente de $\mathrm{CO}, \mathrm{CO}_{2}$ e $\mathrm{H}_{2}$.

Assim, o processo de gaseificação de uma biomassa, como o bagaço de cana-de-açúcar, consiste na sua transformação em um gás combustível, contendo proporções variáveis de monóxido de carbono, dióxido de carbono, hidrogênio, metano, vapor d'água e alcatrões. Porém, a composição no gás combustível dependerá de diversos fatores, tais como, o tipo de gaseificador usado, a introdução ou não de vapor d'água, e principalmente do conteúdo de umidade presente na biomassa usada $32,270,271$.

Vantagens da gaseificação da biomassa:

i. as cinzas e o carbono residual permanecem no gaseificador, diminuindo assim a emissão de particulados;

ii. o combustível resultante é mais limpo e, na maioria dos casos não há necessidade de controle de poluição.

Durante todo o processo de gaseificação, as reações exotérmicas fornecem energia para as reações endotérmicas na forma de calor. 
A previsão da composição de equilíbrio entre elas e os gases que deixam a zona de redução de um gaseificador, para uma dada condição de temperatura e pressão, pode ser deduzida através da utilização das constantes de equilíbrio das principais reações que ali ocorrem, bem como de equações de balanço material e energético, o que acaba eventualmente ocorrendo, mas que foge do campo de discussão deste trabalho ${ }^{272}$.

\subsection{Principais tipos de gaseificadores}

A maioria dos gaseificadores conhecidos atualmente enquadra-se em uma dessas duas concepções - gaseificador de leito fixo ou gaseificador de leito fluidizado (ou circulante), ambos esquematicamente mostrados na FIG. $43^{274}$.

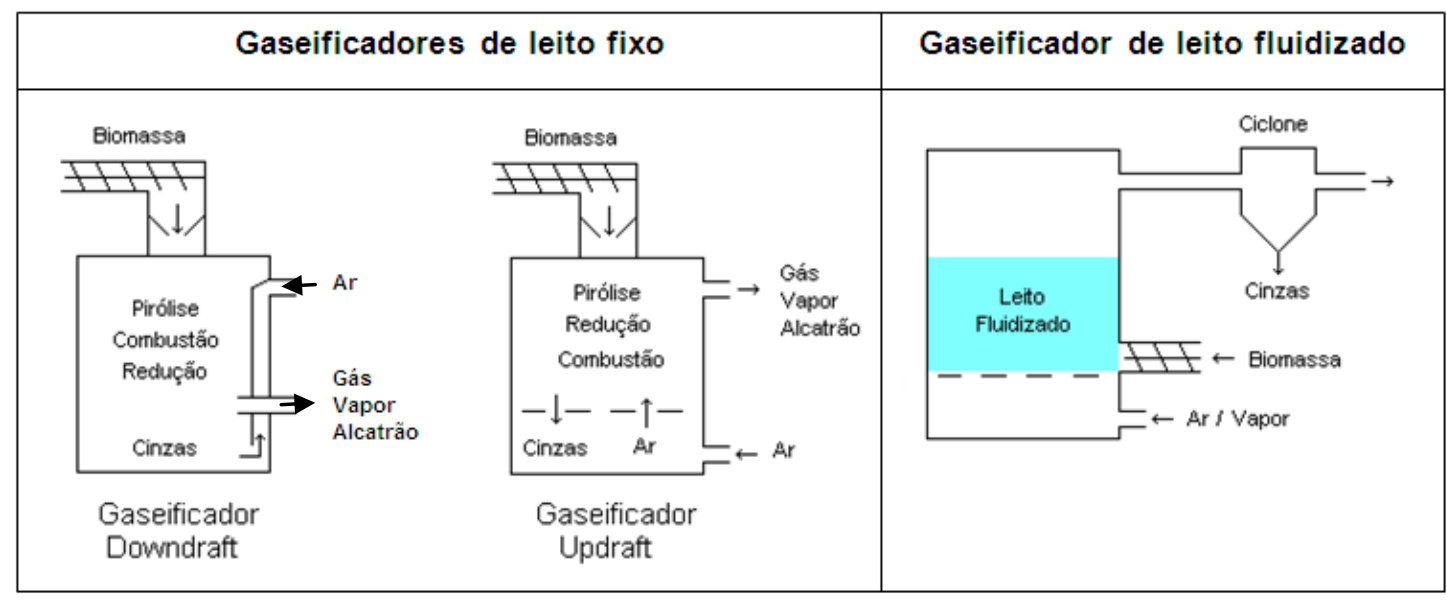

FIGURA 43 - Representação esquemática dos tipos de gaseificadores

Dentre esses dois tipos de gaseificadores, os mais adequados ao que se propõe neste trabalho, são os gaseificadores de leito fixo e, portanto, apenas estes serão aqui abordados.

\section{16. 4 Gaseificadores de leito fixo}

Estes gaseificadores são de pequeno porte e representam a maioria dos gaseificadores em operação ou em construção no mundo. Deles podem ser destacados dois subgrupos: os de circulação de gases contracorrente ("updraft") e os de gases co-corrente ("downdraft"), descritos a seguir: 


\section{16. 4. 1. Gaseificador contracorrente - "updraft" 259}

Chamar-se de "contracorrente" significa referir-se ao fato da biomassa que o alimenta, ser colocada pelo seu topo (ou porta de alimentação) e descer em contracorrente ao ar ou oxigênio ${ }^{275,276}$.

É o sistema mais antigo e simples. Esse tipo de gaseificador pode trabalhar sob pressão atmosférica normal ou pressurizada, e apresenta-se esquematizado na FIG. $44^{266,271,277 .}$

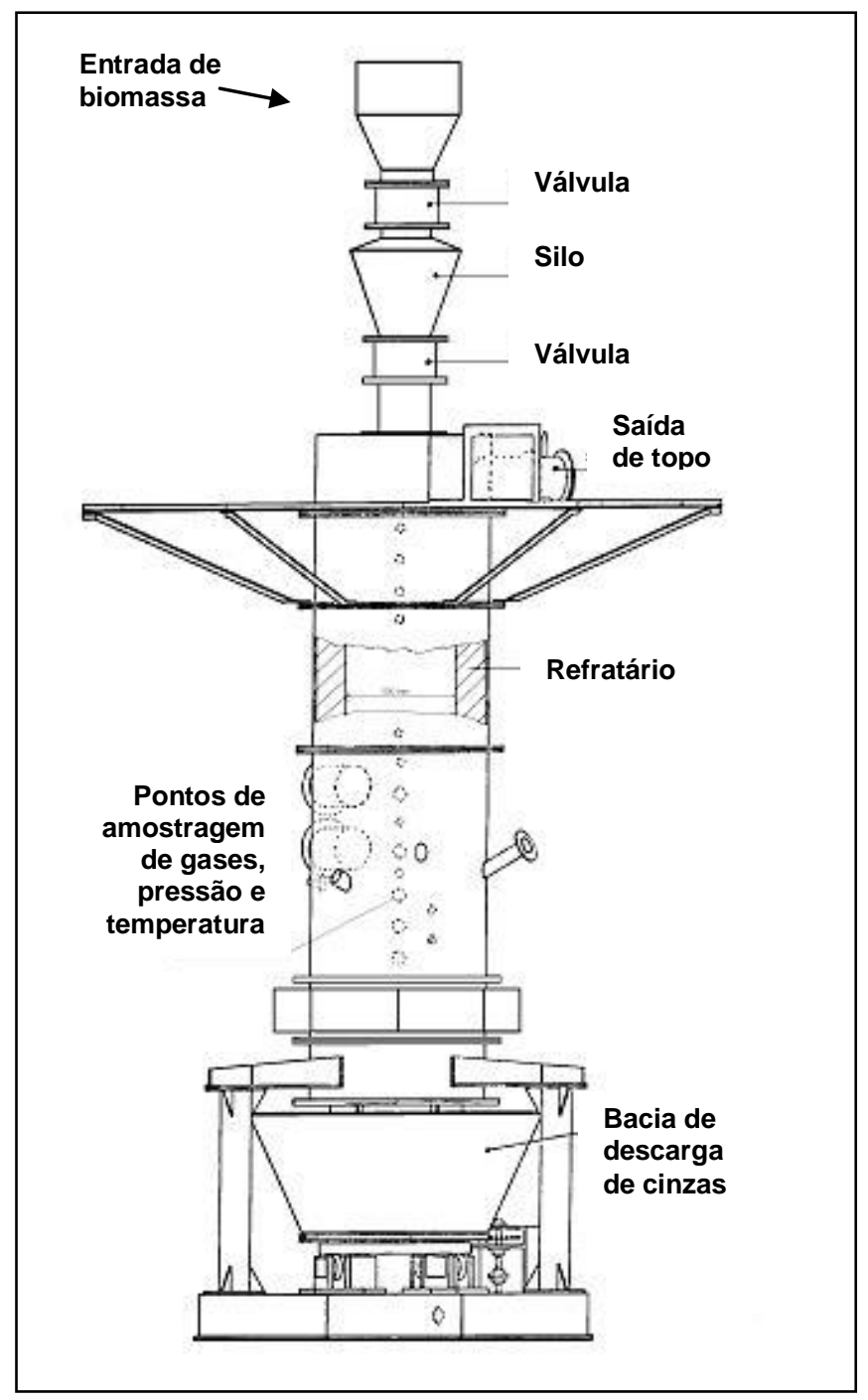

FIGURA 44 - Diagrama de um gaseificador contracorrente atmosférico ou "updraft" 277. 
Como exemplos temos:

i. o gaseificador do IPT - Instituto de Pesquisa e Tecnologia, que opera à pressão atmosférica, e é mostrado em uma fotografia na FIG. 45.

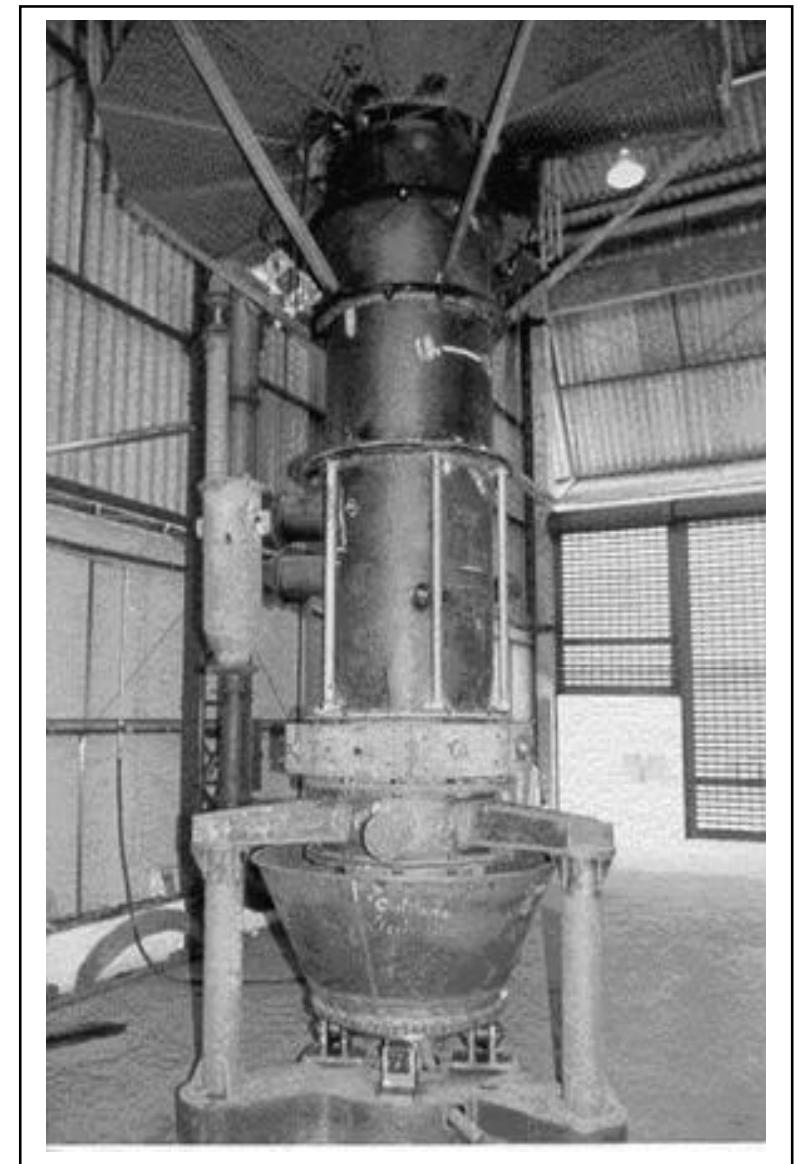

FIGURA 45 - Fotografia do gaseificador contracorrente atmosférico ou "updraft" instalado no IPT ${ }^{259}$.

ii. o gaseificador Lurgi que opera sob pressurização ${ }^{271}$ possuindo capacidade cinco vezes maior que um equivalente atmosférico, porém com complexidade mecânica e operacional significativamente maiores, não sendo competitivo para pequenas capacidades. $\mathrm{Na}$ FIG. 46 é mostrado um esquema do gaseificador Lurgi ${ }^{271,278 .}$ 


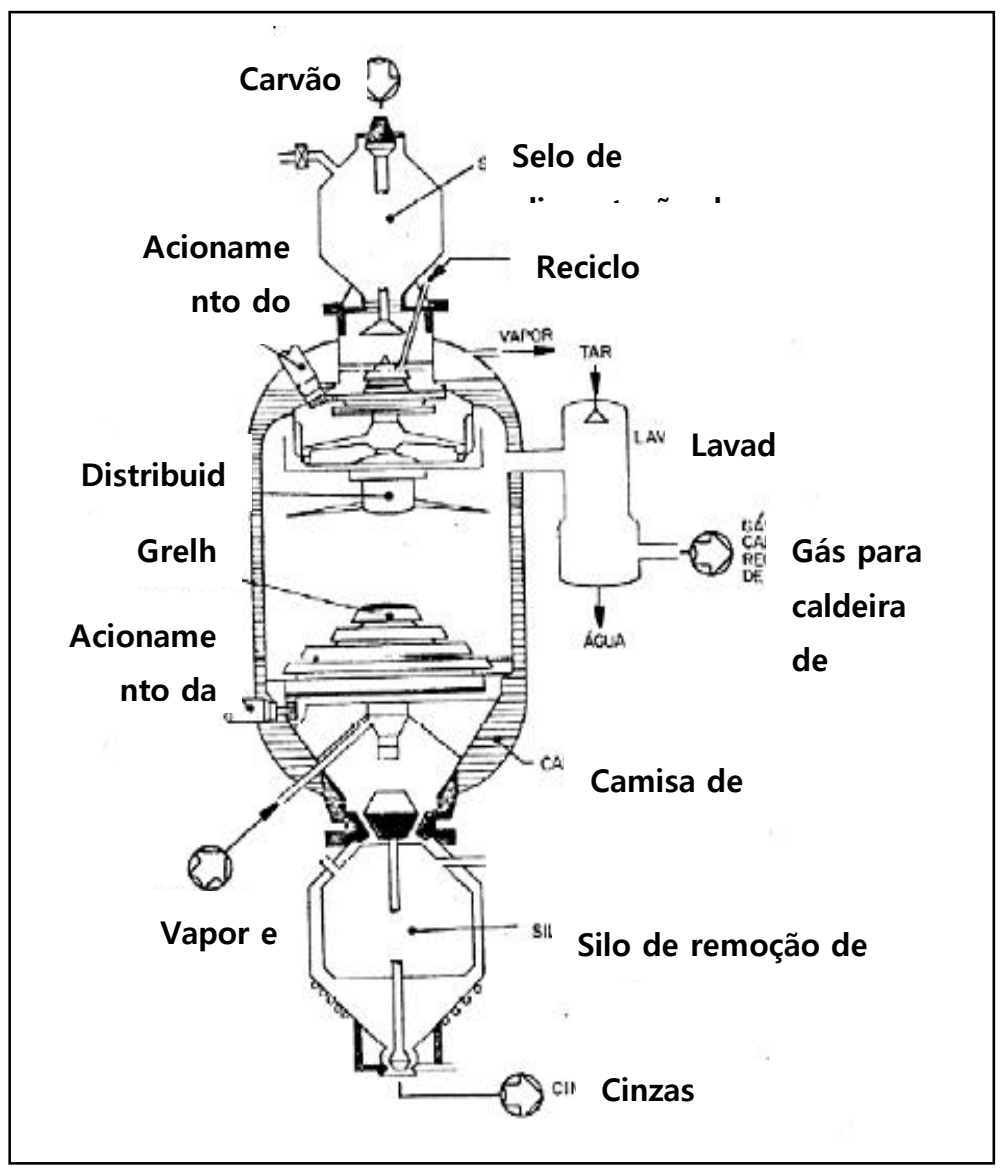

FIGURA 46 - Esquema de gaseificador contracorrente pressurizado de Lurgi.

Principais vantagens do gaseificador contracorrente: $259,266,276$

i. possui uma operacionalidade extremamente simples o que facilita seu manuseio e/ou o aprendizado de sua manipulação;

ii. permite que se opere com uma biomassa em condições elevadas de umidade, sem que haja prejuízos;

iii. podem ser usados resíduos urbanos, mesmo aqueles que tenham altos teores de água;

iv. o local de instalação da grelha tem a capacidade de operar em temperaturas bem elevadas (a menos que se injete $\mathrm{H}_{2} \mathrm{O}_{\text {vapor }}$ ); ${ }^{279}$

v. é capaz de fundir metais e escória (gaseificação com cinza fundida);

vi. para uso em combustão direta, a queima dos alcatrões produzidos no processo, ocorre de forma muito boa; 
O gaseificador contracorrente apresenta algumas desvantagens: $259,266,276$

i. em alguns momentos pode haver excesso de calor e aumento da temperatura na grelha do gaseificador, prejudicando seu funcionamento e exigindo sua troca;

ii. há necessidade de haver uma uniformização da granulometria da biomassa a ser utilizada evitando-se a perda da mesma no processo;

iii. o gás produzido possui alto teor de alcatrão, gerado na pirólise;

\section{16. 4. 2. Gaseificador co-corrente - "downdraft" 259,278}

O gaseificador co-corrente, também chamado de gaseificador de queima de alcatrão, assemelha-se construtivamente ao gaseificador contracorrente, exceto que o ar e o gás fluem para baixo, na mesma direção que o combustível que foi utilizado 275 .

Esta mudança de sentido faz toda a diferença para um combustível com teor elevado de matéria volátil como a biomassa, pois o ar injetado induz à queima de até $99,9 \%$ do alcatrão liberado pelo combustível (daí a denominação queima de alcatrão) ${ }^{271,277,279}$.

O que ocorre é que $\mathrm{o}$ ar introduzido no gaseificador encontra primeiro a biomassa não queimada e a temperatura máxima ocorre na fase gasosa, na região de pirólise ${ }^{280}$. Aquele material que estiver no estado sólido, localizado logo acima desta região, acaba então por sofrer uma pré-queima, um aquecimento e secagem, promovidos pela troca de calor por radiação. Isso leva à evaporação da água contida no interior das partículas, que retarda ou até impede a formação de gases com alto teor de alcatrão ${ }^{266,276}$.

O gaseificador co-corrente ou "downdraft" é usado em diferentes locais no planeta, e tem sido atualizado e melhorado em institutos e laboratórios, como o NREL (National Renewable Energy Laboratory) nos EUA e no IIS (Indian Institute of Science) na Índia $276,281,282$. 
Em termos de estudo, o gaseificador co-corrente estratificado, uma variação do sistema original, é o que vem sendo mais estudado, pois opera com a pressão atmosférica normal ${ }^{276,279,282,283}$.

Na FIG. 47 é mostrado um esquema desse tipo de gaseificador, bem como as principais partes que o compõem ${ }^{282}$.

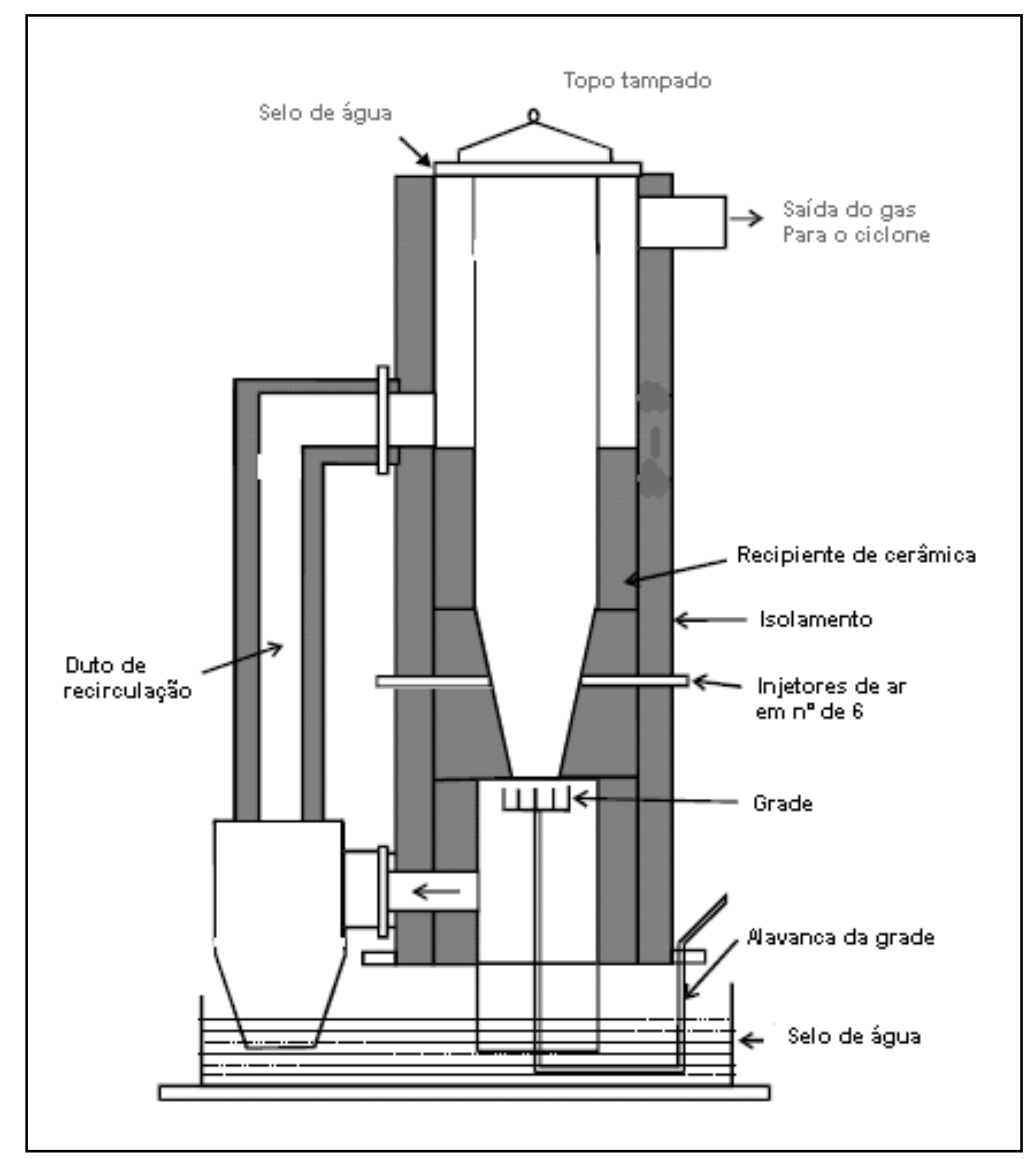

FIGURA 47 - Gaseificador co-corrente de topo aberto usado no Indian Institute of Science (IIS).

Principais vantagens do gaseificador co-corrente: ${ }^{259,275,284}$

i. os gaseificadores de topo aberto são os que apresentam riscos quase nulos em casos de explosão;

ii. a grande maioria dos materiais inorgânicos fica retida, formando uma massa de cinzas e carvão, que pode ser retirada pela parte inferior do gaseificador, diminuindo grandemente a necessidade de usarem-se filtros a quente; 
iii. o gás obtido, quando limpo, pode ser usado, sem modificações, em motores de linha;

iv. consome cerca de 99 a 99,9 \% do alcatrão produzido, eliminando o principal empecilho para o transporte em tubulações e 0 uso em motores com um mínimo de limpeza;

v. esse gaseificador é um sistema comprovadamente seguro, visto que foi usado em mais de um milhão de veículos durante a Segunda Guerra Mundial;

As principais desvantagens do gaseificador co-corrente são: ${ }^{259,275,284}$

i. de modo geral, de 4 a $7 \%$ do carbono do combustível biomassa acaba não sendo convertido, saindo com as cinzas que se formam na grelha no fundo do gaseificador;

ii. o gás volátil que sai do gaseificador está em altas temperaturas, girando em torno de $700^{\circ} \mathrm{C}$, o que leva a perder-se energia. Para evitar-se essa perda, é preciso que se criem mecanismos que aproveitem essa energia, tais como a secagem da biomassa, seu pré-aquecimento e até o aquecimento do ar e/ou oxigênio usado no processo;

iii. o combustível utilizado para alimentá-lo deverá possuir uma umidade baixa, com cerca de menos de $20 \%$ de água;

iv. esse combustível deve também apresentar uma granulometria uniforme, levando à imposição de se adquirir um mecanismo que leve à formação de pedaços de biomassa uniformes antes de serem colocados no gaseificador, sob pena de interferir na eficiência do processo.

\section{17. A gaseificação no mundo ${ }^{285}$}

Dentro do continente da América do Sul, observa-se que o uso do processo de gaseificação é, ainda, tímido e comparativamente inferior, em relação aos demais continentes ${ }^{259}$. 
$\mathrm{Na}$ constatação desse fato deve-se levar em consideração que a biomassa e os resíduos agrícolas, presentes, por exemplo, em nosso território, ainda são bem pouco direcionados para o processo de geração de energia dentro das propriedades consideradas ${ }^{251,286}$.

A FIG. 48 demonstra os estudos e as principais projeções do crescimento da gaseificação no mundo ${ }^{281,287}$.

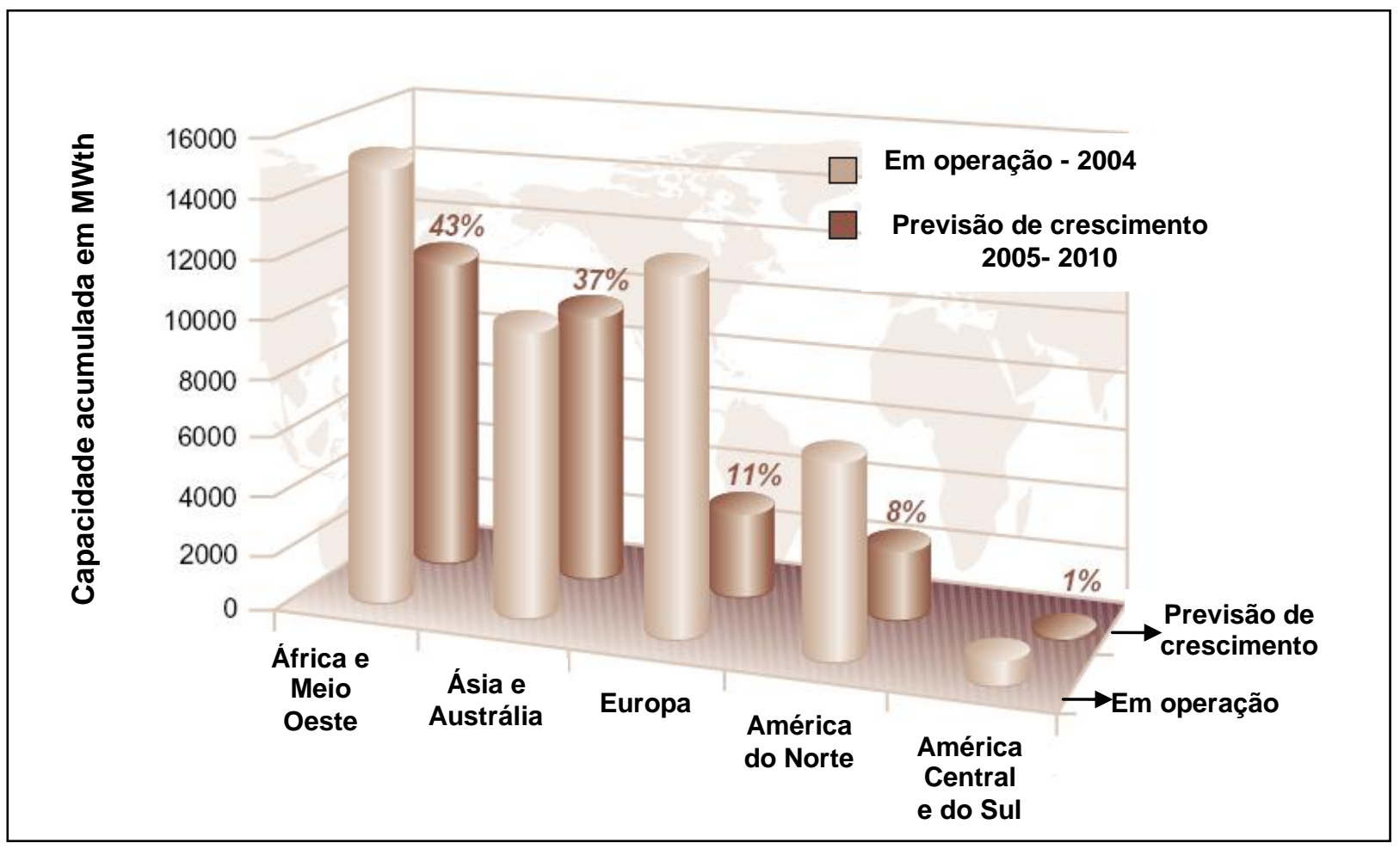

Figura 48 - Projeções de crescimento da gaseificação mundial ${ }^{287}$.

A África do Sul e a China são os países produtores dominantes em gaseificação no mundo. Há três locais na região de Sasol, na África do Sul, que produzem combustível limpo e produtos químicos, respondendo por um terço da gaseificação mundial. Nesses locais, as usinas somam 107 gaseificadores, cerca de $28 \%$ do total mundial.

A China começou a construir usinas de gaseificação em meados de 1980 e atualmente possui 22 usinas de gaseificação operando, que convertem carvão e resíduos de petróleo em uma variedade de produtos químicos, fertilizantes e combustíveis gasosos. Essa capacidade corresponde a um total de $30 \%$ de gás de síntese do planeta ${ }^{287,288}$. 


\section{18. A gaseificação no Brasil}

O Brasil, apesar de possuir as condições adequadas à produção de biomassa para fins energéticos: clima tropical úmido, terras disponíveis, mão-deobra rural abundante e carente de oportunidades de trabalho, e nível industrial tecnológico compatível, anda a passos lentos nesse campo, com participação insípida. Suas maiores ações resumem-se a projetos de pesquisa em universidades e institutos, intimamente ligados à produção de biocombustíveis, sem outros enfoques que o potencial da biomassa possui ${ }^{180,264}$.

A biotecnologia tem papel relevante nesta questão quando está voltada para a adaptação dos cultivos energéticos, para o aumento da produtividade por hectare e para incrementar uma maior densidade de elementos energéticos, como celulose, açúcar, amido e óleos vegetais ${ }^{289}$.

Porém, esse aumento no uso da biomassa dependerá, ainda, de maiores pesquisas, mais investimentos e inovações tecnológicas, além da melhoria do processamento e o aumento de sua eficiência, não só no caso da biomassa, como também de outras fontes energéticas. ${ }^{263}$.

Nosso país ainda engatinha em termos de aplicabilidade prática da gaseificação, e ao que tudo indica, deverá permanecer assim pela falta de interesse dos governantes, indústrias e empresas ${ }^{290}$.

O potencial brasileiro de biomassa permanece focado nos biocombustíveis, o que é extremamente positivo em termos de competitividade mundial e na busca da independência de combustíveis fósseis.

O país, porém, não deveria limitar-se a uma ampliação de programas como o Programa Nacional do Álcool - Pró-Álcool, por exemplo, mas a um leque maior de outras ações, observando as nossas linhas de pesquisas restritas a universidades, e que apesar disso, têm grande projeção internacional e são referência mundial ${ }^{193}$.

\section{18. 1. Organizações de pesquisas de gaseificação no Brasil ${ }^{259}$}

i. UNICAMP - Universidade de Campinas - realiza pesquisas com um gaseificador de leito fluidizado. Na FIG. 49 é mostrada uma fotografia desse reator instalado no Departamento de Engenharia Térmica e Fluídos (DETF) da Faculdade de Engenharia Mecânica 
(FEM) na UNICAMP ${ }^{282}$. Uma planta piloto de gaseificação de biomassa para eletrificação rural está sendo desenvolvida pela equipe do Laboratório de Combustíveis e Combustão da Faculdade de Engenharia Mecânica da UNICAMP 275,291,292.

Outros gaseificadores estão sendo construídos e em testes de operação e otimização, que serão utilizados para desenvolvimento de pesquisas científicas ${ }^{293}$.

De acordo com a Universidade pretende-se, futuramente, utilizar o conhecimento acumulado em uma planta de demonstração para a eletrificação rural ${ }^{275,291,294}$.

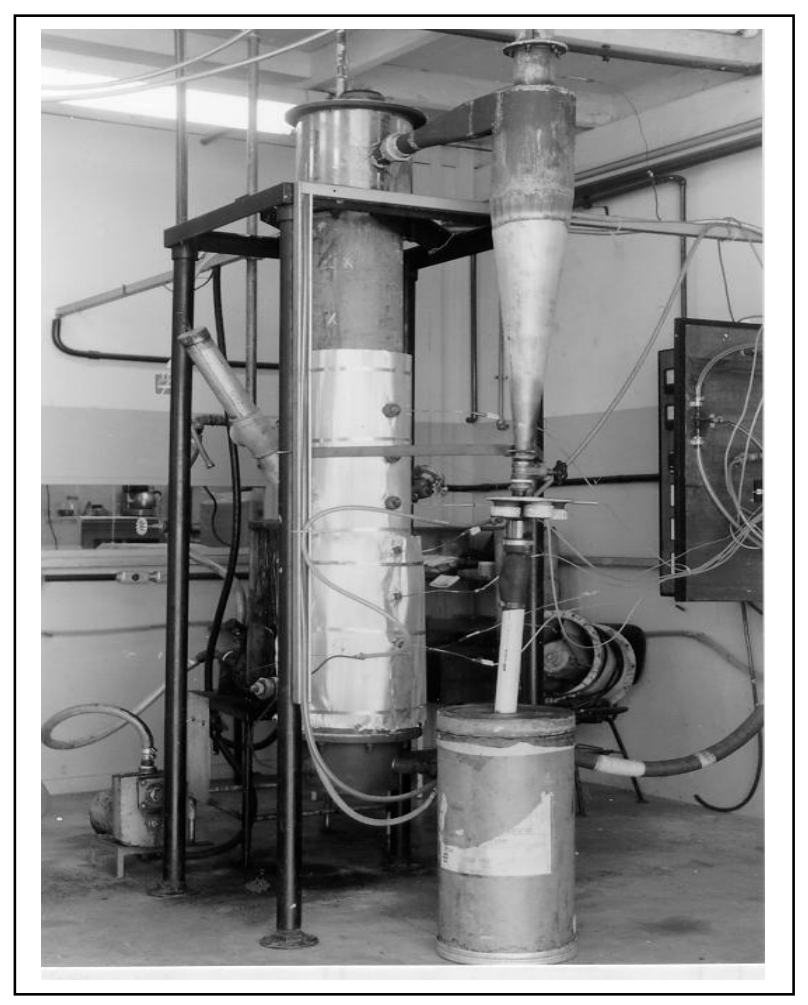

FIGURA 49 - Reator de Leito Fluidizado Instalado na FEM da Unicamp ${ }^{259}$.

ii. IPT - Instituto de Pesquisas Tecnológicas - no Laboratório de Combustão e Gaseificação do IPT, há algumas instalações piloto, montadas para trabalhos de investigação experimental, como a fotografia mostrada na FIG. 50, de um gaseificador de leito fluidizado. Atualmente o IPT, em parceria com a CENBIO, desenvolve o BUN - Biomass Users Network do Brasil e a Universidade do Amazonas, no projeto GASEIFAMAZ ${ }^{259}$. 


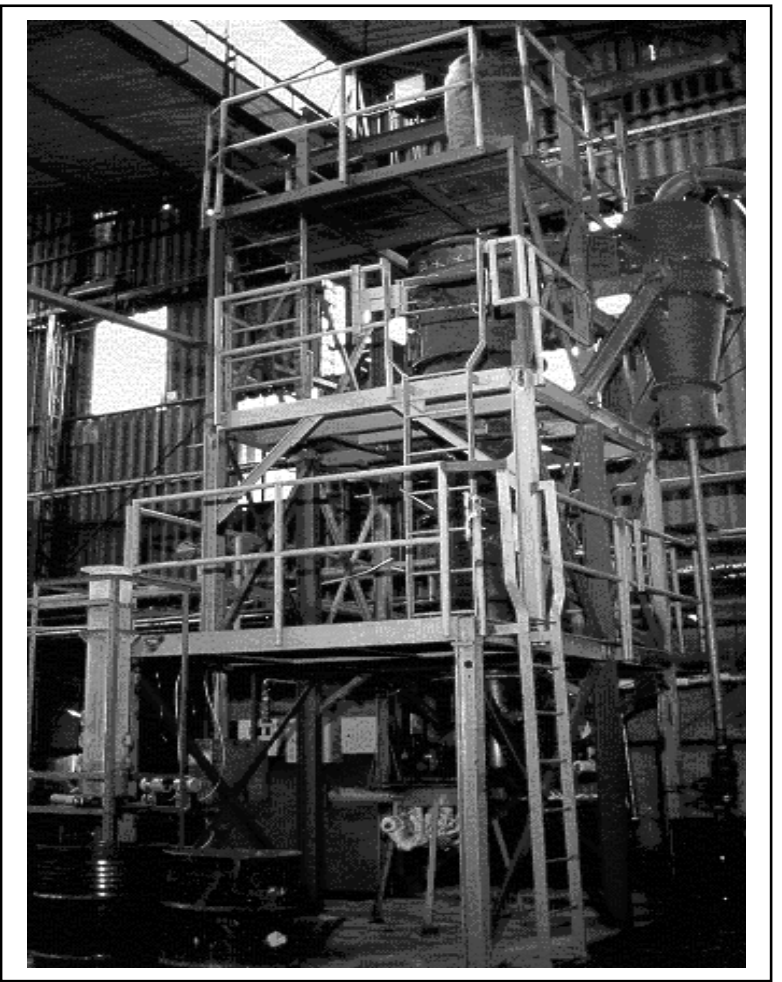

Figura 50 - Gaseificador de Leito Fluidizado Instalado no IPT ${ }^{259}$.

iii. UFPA - Universidade Federal do Pará - realiza pesquisa com gaseificação de resíduos de biomassa para a produção de energia. Os departamentos de Engenharia Elétrica e de Engenharia Mecânica da UFPA vem desenvolvendo projetos ${ }^{292,295,296}$ utilizando vários tipos de resíduos da flora paraense, na produção de briquetes energéticos e na produção de vapor, entre outros.

Atualmente a UFPA está desenvolvendo o "Programa ENERBIO / UFPA com o uso de resíduos de biomassa de açaí e cacau para a produção de energia"

iv. EFEI - Universidade Federal de Itajubá - sobre coordenação do Prof. Dr. Electo Silva Lora está trabalhando atualmente em um projeto de gaseificação financiado pela CEMIG - Companhia Energética de Minas Gerais, COPERSUCAR - Cooperativa de Produtos de Cana, Açúcar e Álcool do Estado de São Paulo Ltda e pela FINEP - Financiadora de Estudos e Projetos. O gaseificador é 
de leito fluidizado circulante e será alimentado com casca de arroz, serragem e bagaço de cana.

O Prof. Dr. Luiz Augusto Horta Nogueira, da Universidade Federal de Itajubá, desenvolveu o Projeto WBP-SIGAME - Wood Biomass Project / Sistema Integrado de Gaseificação de Madeira para a Produção de Eletricidade, em testes ${ }^{259,289}$.

\section{19. Gás de síntese}

O processo de gaseificação resulta de um conjunto de reações, que ocorrem nas diferentes regiões do gaseificador ou em todo o volume do mesmo.

Gás de síntese é o nome dado a uma mistura de gases de composição química variada formada a partir da gaseificação da biomassa ou de outros combustíveis sólidos. Este gás pode ser usado tanto para processos de síntese como para a geração de eletricidade. Na FIG. 51, encontra-se um diagrama que mostra as principais aplicações do gás de síntese ${ }^{297}$.

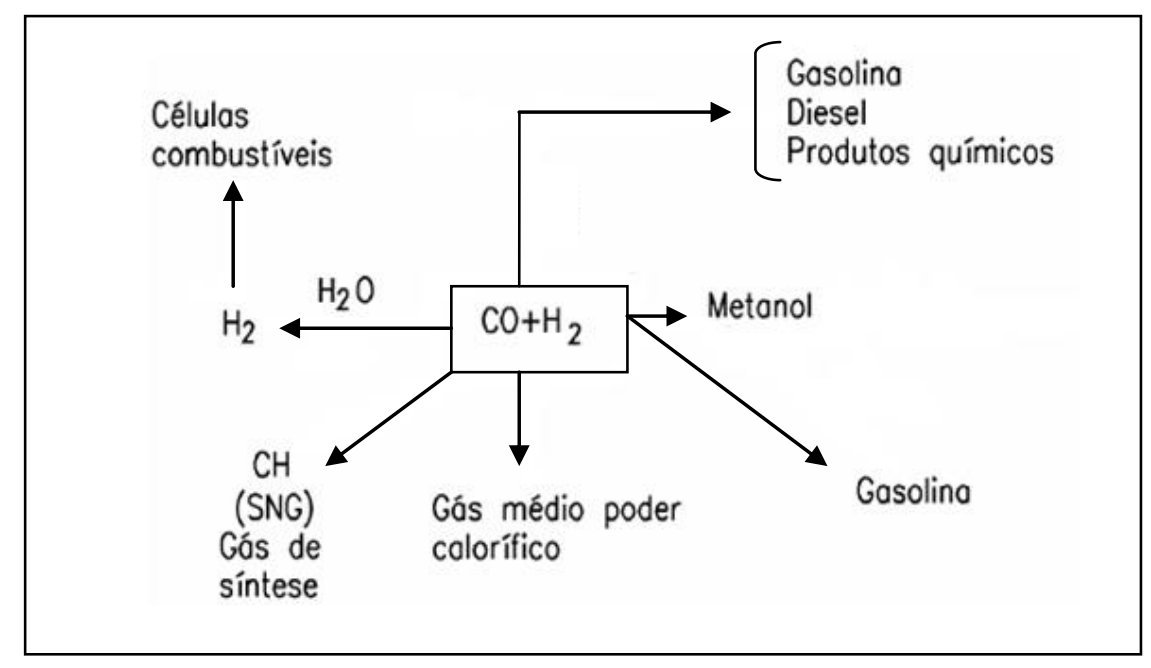

FIGURA 51 - Principais aplicações do gás de síntese

\section{19. 1 Composição do gás de síntese}

Segundo Mukunda, a quantidade de gás carbônico produzida com a utilização dos sistemas de gaseificação, sem a presença de vapor, possui uma média de $12 \%$ do resíduo de biomassa utilizado ${ }^{280,282}$.

Na TAB. 22, apresenta-se a composição média desse gás. 
TABELA 22 - Composição média do gás de síntese ${ }^{282}$.

\begin{tabular}{cc}
\hline Gás & Porcentagem (\%) \\
\hline Hidrogênio & $6,5 \pm 2$ \\
Monóxido de carbono & $19 \pm 1$ \\
Metano & $1,5 \pm 0,5$ \\
Dióxido de carbono & $12 \pm 1$ \\
Nitrogênio & 48 \\
\hline
\end{tabular}

Com a utilização do processo de gaseificação onde se inclua o vapor de água, segundo Gao et al (2008), a quantidade de gás carbônico produzido e presente no gás resultante formado, tende a aumentar consideravelmente e acaba por ficar com uma porcentagem média de $25 \%{ }^{270,298}$.

Na FIG. 52 é mostrado, graficamente, a formação de $\mathrm{CO}_{2}$, em volume, na gaseificação a vapor ${ }^{298}$.

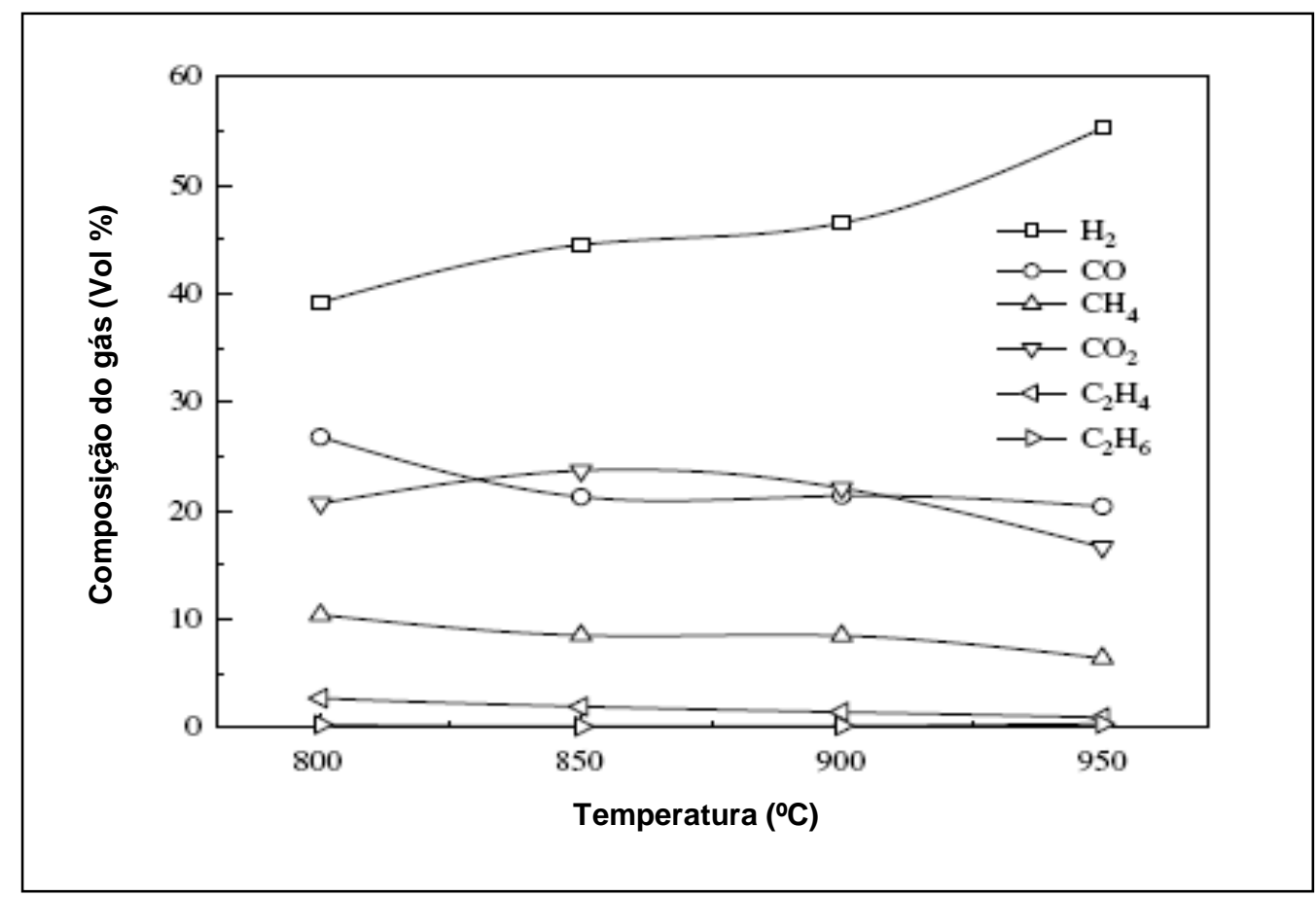

FIGURA 52 - Efeitos da temperatura na composição e formação do $\mathrm{CO}_{2}$, com 0 uso de vapor de água. 


\section{20. Considerações sobre captura e fixação de $\mathrm{CO}_{2}$}

Combustíveis fósseis tem sido, há tempos, o principal motor para nossa sociedade industrial, fornecendo energia com custos relativamente baixos.

Ao mesmo tempo, a maioria das emissões antropogênicas relatadas são devido ao uso desses combustíveis e o aumento das emissões de $\mathrm{CO}_{2}$ tem desafiado os países do mundo a encontrar novos e melhores meios de aumentar a disponibilidade de energia e, ao mesmo tempo, reduzir a emissão desse e de outros GEE.

O surgimento de tecnologias que possam sequestrar $\mathrm{CO}_{2}$ como processos com solventes químicos, absorção física, sequestro subterrâneo, fixação biológica, entre outros, têm aberto uma porta nesse processo de mitigação.

$\mathrm{E}$, se, ao mesmo tempo, essas tecnologias de captura beneficiarem a agricultura e a economia, certamente serão estratégias que encontrarão abertura em qualquer segmento afim.

\section{20. 1. Processo de captura de $\mathrm{CO}_{2}$ por absorção em hidróxido de amônio}

Uma abordagem que pode indicar uma rota para reduzir as emissões de $\mathrm{CO}_{2}$ é sua separação, por absorção, através de hidróxido de amônio $\left(\mathrm{NH}_{4} \mathrm{OH}\right)$.

Pesquisas experimentais relatadas na literatura baseiam-se na utilização da amônia aquosa, que em condições normais de temperatura e pressão (CNTP), possui uma capacidade de absorção de $\mathrm{CO}_{2}$ elevada quando comparada a outras técnicas, apresentando uma eficiência em torno de 95 99\% ${ }^{301,304,317,321}$.

Possíveis reações entre amônia e gás carbônico estão indicadas nas equações (3) a (10) a seguir e ocorrem a diferentes temperaturas e condições operacionais. $301,304,317,320,321$

$$
\begin{aligned}
\mathrm{CO}_{2}(\mathrm{~g})+2 \mathrm{NH}_{3}(\mathrm{~g}) & \leftrightarrow \mathrm{NH}_{2} \mathrm{COONH}_{4}(\mathrm{~s}) \\
\mathrm{NH}_{2} \mathrm{COONH}_{4}(\mathrm{~s})+\mathrm{H}_{2} \mathrm{O}(\mathrm{g}) & \leftrightarrow\left(\mathrm{NH}_{4}\right)_{2} \mathrm{CO}_{3}(\mathrm{~s})
\end{aligned}
$$




$$
\begin{aligned}
& \mathrm{CO}_{2}(\mathrm{~g})+2 \mathrm{NH}_{3}(\mathrm{~g}) \longleftrightarrow \mathrm{CO}\left(\mathrm{NH}_{2}\right)_{2}(\mathrm{~s})+\mathrm{H}_{2} \mathrm{O}(\mathrm{g}) \\
& \mathrm{CO}_{2}(\mathrm{~g})+2 \mathrm{NH}_{3}(\mathrm{aq}) \longrightarrow \mathrm{NH}_{2} \mathrm{COO}^{-}(\mathrm{aq})+\mathrm{NH}_{4}^{+}(\mathrm{aq}) \\
& 2 \mathrm{NH}_{3}(\mathrm{~g})+\mathrm{CO}_{2}(\mathrm{~g})+\mathrm{H}_{2} \mathrm{O}(\mathrm{g}) \leftrightarrow\left(\mathrm{NH}_{4}\right)_{2} \mathrm{CO}_{3}(\mathrm{~s}) \\
& \mathrm{NH}_{3}(\mathrm{~g})+\mathrm{CO}_{2}(\mathrm{~g})+\mathrm{H}_{2} \mathrm{O}(\mathrm{g}) \leftrightarrow \mathrm{NH}_{4} \mathrm{HCO}_{3}(\mathrm{~s}) \\
& 2 \mathrm{NH}_{3}(\mathrm{aq})+\mathrm{CO}_{2}(\mathrm{~g})+\mathrm{H} \mathrm{O}(\mathrm{I}) \leftrightarrow\left(\mathrm{NH}_{4}\right)_{2} \mathrm{CO}_{3}(\mathrm{~s}) \\
& \mathrm{NH}_{3}(\mathrm{aq})+\mathrm{CO}_{2}(\mathrm{~g})+\mathrm{H}_{2} \mathrm{O}(\mathrm{l}) \leftrightarrow \mathrm{NH}_{4} \mathrm{HCO}_{3}(\mathrm{~s})
\end{aligned}
$$

As reações indicadas nas equações (3) e (4) ocorrem em condições anidras e podem ser usadas para diminuir as emissões de $\mathrm{CO}_{2}$ por meio do gás $\mathrm{NH}_{3} 301,308$.

$\mathrm{O}$ carbamato de amônio $\left(\mathrm{NH}_{2} \mathrm{COONH}_{4}\right)$ é a principal substância formada pela reação entre o dióxido de carbono e amônia, em condições anidras, conforme indicado na equação (3).

O carbamato de amônio é muito solúvel em água e o produto hidratado formado, o carbonato de amônio, $\left(\left(\mathrm{NH}_{4}\right)_{2} \mathrm{CO}_{3}\right)$, apresenta-se indicado na equação (4).

As duas reações ocorrem a temperaturas entre 38 a $60 \stackrel{\circ}{\circ}$ 301,304,308,311,317,320,321.

Entretanto, há duas preocupações quando se trabalha em condições anidras. Primeiro, caso a concentração de $\mathrm{CO}_{2}$ seja alta, o que pode significar mais de $16 \%(\mathrm{v} / \mathrm{v})$, uma grande quantidade de $\mathrm{NH}_{3}$ será necessária para que efetivamente possa causar diminuição das emissões de $\mathrm{CO}_{2}$, implicando em risco de explosão se a reação entre ambos não for adequadamente operada, já que o limite para que a amônia gasosa entre em explosão está em torno de 15 a 28\% $(\mathrm{v} / \mathrm{v})$.

Segundo, durante a passagem das substâncias ao longo das tubulações do reator, podem ocorrer obstruções interrompendo o processo ${ }^{301,304,317,321,322}$. 
Sob alta pressão e com temperaturas maiores que $140 \stackrel{\circ}{ } \mathrm{C}$, a reação entre $\mathrm{CO}_{2}$ e $\mathrm{NH}_{3}$ forma a uréia $\left(\mathrm{CO}\left(\mathrm{NH}_{2}\right)_{2}\right)$, conforme indicado na equação (5), $301,304,317,320,321$

Assim, por segurança e simplicidade, o método por via úmida é o mais indicado ${ }^{301,304,317,321 .}$.

As reações representadas pelas equações (6) a (10) ocorrem à temperatura ambiente e pressão atmosférica, sendo que a formação dos íons amônio $\left(\mathrm{NH}_{4}{ }^{+}\right)$e carbamato $\left(\mathrm{NH}_{2} \mathrm{COO}^{-}\right)$indicados na equação (6) ocorre de forma muito rápida e é irreversível. ${ }^{301,304,310,311 .}$

Todas as reações indicadas (7) a (10) são reversíveis e ocorrem predominantemente à temperatura ambiente e pressão atmosférica, formando como produtos o carbonato de amônio $\left(\left(\mathrm{NH}_{4}\right)_{2} \mathrm{CO}_{3}\right)$ ou bicarbonato de amônio $\left(\mathrm{NH}_{4} \mathrm{HCO}_{3}\right)^{309,310,311,321,323,324}$.

As reações exemplificadas pelas equações (9) e (10) são as mais prováveis de ocorrer nos estudos realizados para a remoção de $\mathrm{CO}_{2}$ por borbulhamento em amônia aquosa, realizadas à temperatura ambiente e pressão atmosférica. $^{301,304,317,321 .}$.

Porém, a velocidade com que $\mathrm{O}_{\mathrm{CO}_{2}}$ é absorvido, sua velocidade de difusão e seu equilíbrio de vapor/líquido em solução de hidróxido de amônio não têm sido muito pesquisados ${ }^{301,304}$.

A captura do $\mathrm{CO}_{2}$ ocorre por meio de uma reação rápida, com elevada taxa de remoção e alta capacidade de retenção. Essa tecnologia pode ser promissora e de grande interesse para minimizar a emissão de $\mathrm{CO}_{2}$ para a atmosfera ${ }^{310} . \mathrm{X}$

Na parte experimental deste trabalho comprova-se a eficiência de remoção do gás carbônico por sua absorção em uma solução de hidróxido de amônio concentrado e $\mathrm{H}_{2} \mathrm{O}$, na proporção de 1:1, conforme a reação representada pela equação (11) $301,304,317,321$.

$$
\mathrm{NH}_{4} \mathrm{OH}(\mathrm{aq})+\mathrm{CO}_{2}(\mathrm{~g})+\mathrm{H}_{2} \mathrm{O}(\mathrm{I}) \longrightarrow \mathrm{NH}_{4} \mathrm{HCO}_{3}(\mathrm{~s})+\mathrm{H}_{2} \mathrm{O}
$$

Segundo estudos de Bai e Yeh (1997) ${ }^{301}$ e Liu e Wang (2009) ${ }^{304}$ a capacidade de absorção do $\mathrm{CO}_{2}$ em $\mathrm{NH}_{3}$ aquosa é cerca de 0,9 kg de $\mathrm{CO}_{2}$ por quilo de reagente usado, valor utilizado nos cálculos deste trabalho. 
Ressalta-se que, quando se realiza a gaseificação da biomassa, captura-se - $\mathrm{CO}_{2}$ presente no gás de síntese, numa reação química semelhante para produção do fertilizante bicarbonato de amônio.

\section{20. 2. Processo de fixação de $\mathrm{CO}_{2}$ pela formação de compostos no solo}

É conhecido que quando o fertilizante bicarbonato de amônio $\left(\mathrm{NH}_{4} \mathrm{HCO}_{3}\right)$ é colocado no solo: ${ }^{300,301,302,306}$

i. tem efeito de fertilização pelo nitrogênio na colheita, semelhante a outros fertilizantes nitrogenados como o sulfato de amônio $\left(\left(\mathrm{NH}_{4}\right)_{2} \mathrm{SO}_{4}\right)$, a uréia $\left(\mathrm{CO}\left(\mathrm{NH}_{2}\right)\right)$ ou o cloreto de amônio $\left(\mathrm{NH}_{4} \mathrm{Cl}\right)$;

ii. ioniza-se em $\mathrm{NH}_{4}{ }^{+}$(íon amônio) e $\mathrm{HCO}_{3}^{-}$(íon hidrogênio carbonato), sendo que este último pode reagir com minerais alcalinos, como cálcio $\left(\mathrm{Ca}^{2+}\right)$ e magnésio $\left(\mathrm{Mg}^{2+}\right)$, por exemplo, presentes no solo, neutralizando-os, pois ao combinarem-se com esse ácido, formarão um mineral carbonatado.

A equação (12) a seguir, explicita como é o tipo de reação que ocorre com o mineral cálcio, por exemplo: ${ }^{300,301}$

$$
\mathrm{HCO}_{3}^{-}+\mathrm{Ca}^{2+}+\mathrm{OH}^{-} \rightarrow \mathrm{H}_{2} \mathrm{O}+\mathrm{CaCO}_{3} \downarrow
$$

Produtos sólidos como o carbonato de cálcio $\left(\mathrm{CaCO}_{3}\right)$, que são resultantes da reação, são formas perfeitamente estáveis de sequestrar o $\mathrm{CO}_{2}$.

Destaca-se também o interessante comportamento que os solos em geral, têm de agir como um material capaz de ser trocador de íons, retendo íons positivos como $\circ \mathrm{NH}_{4}^{+}$, mas permitindo que íons negativos como $\circ \mathrm{HCO}_{3}^{-}$ percolem com a irrigação natural para o subsolo ${ }^{307}$. 
A explicação para isso é que os solos alcalinos têm, em sua maioria, uma carga superficial de partículas negativas, que possuem maior afinidade por espécies carregadas positivamente, como $\mathrm{O} \mathrm{NH}_{4}{ }^{+}$, do que por espécies carregadas negativamente, como o $\mathrm{HCO}_{3}^{-}{ }^{-300,307}$.

Podemos perceber que este é um diferencial em relação aos fertilizantes industriais que são à base de nitrato de amônio $\left(\mathrm{NH}_{4} \mathrm{NO}_{3}\right)$.

$\mathrm{O} \mathrm{NO}_{3}^{-}$(de carga negativa) neles presente, pode facilmente penetrar no subsolo através da irrigação, resultando não somente na perda do fertilizante como na contaminação do lençol freático por esse íon.

Entretanto, se o bicarbonato de amônio $\left(\mathrm{NH}_{4} \mathrm{HCO}_{3}\right)^{300}$ for utilizado como fertilizante o resultado pode ser altamente benéfico.

Na FIG. 53 é mostrada a tecnologia explicada até o momento e como o processo ocorre no solo ${ }^{300}$.
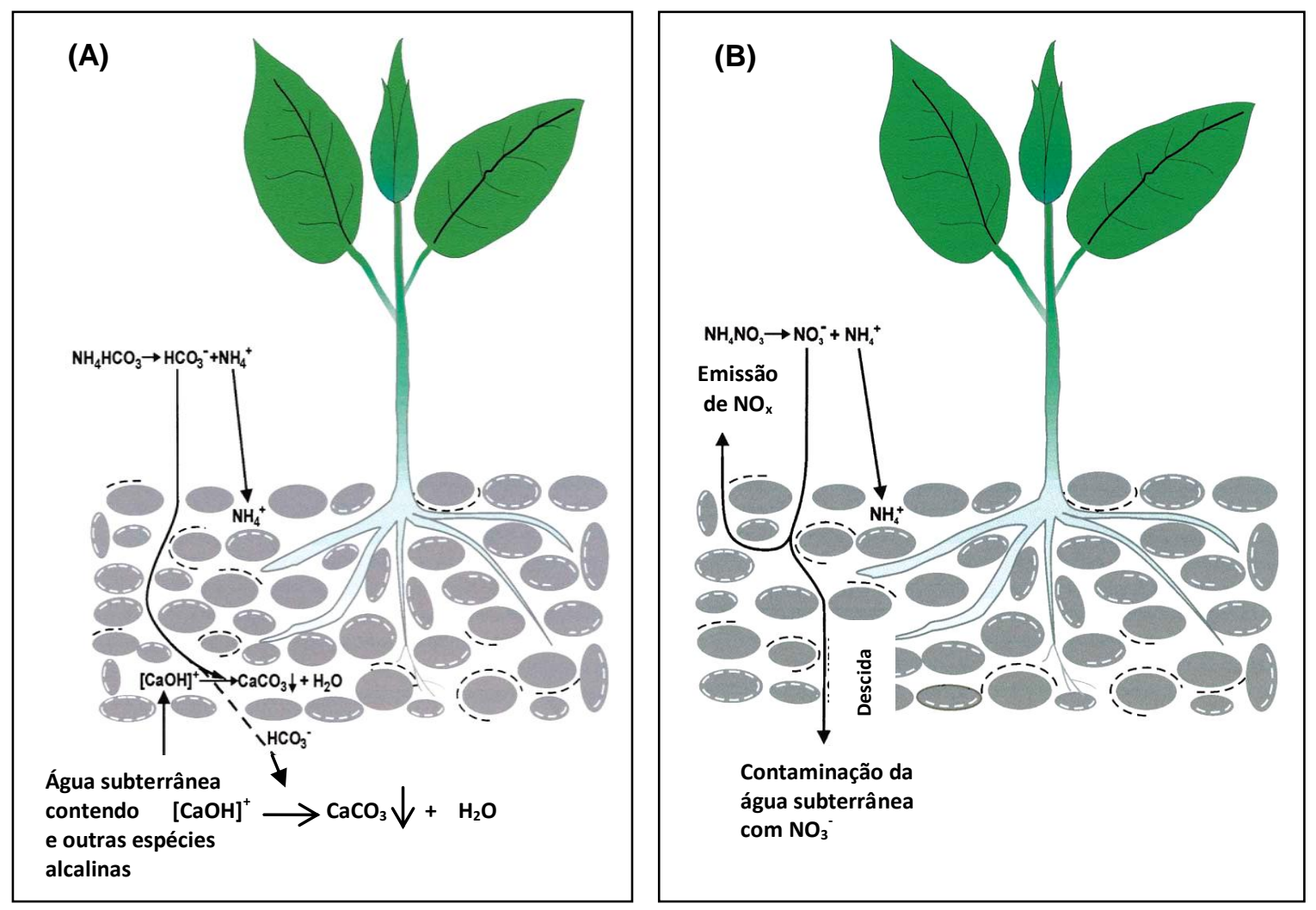

FIGURA 53 - (A) - Sequestro de $\mathrm{CO}_{2}$ nas camadas do solo e subsolo pela formação de carbonato de cálcio.

(B) - Exemplo de como é a contaminação por meio de outros fertilizantes nitrogenados. 


\section{METODOLOGIA}

Esta seção irá apresentar a metodologia usada para determinar a quantidade de $\mathrm{CO}_{2}$ proveniente da gaseificação da biomassa, sua utilização para a produção do bicarbonato de amônio e a quantidade de créditos de carbono decorrente dessa captura, num enfoque inédito na literatura.

\section{1. Captura de $\mathrm{CO}_{2}$ e a produção de fertilizante}

Nas instalações do laboratório do $\mathrm{CCCH}$, do IPEN - USP foi realizada um experimento objetivando a verificação da captura de $\mathrm{CO}_{2}$ com a formação de bicarbonato de amônio que poderá ser utilizado como fertilizante.

O experimento foi realizado em um equipamento como mostrado na fotografia da FIG. 54.

(A)

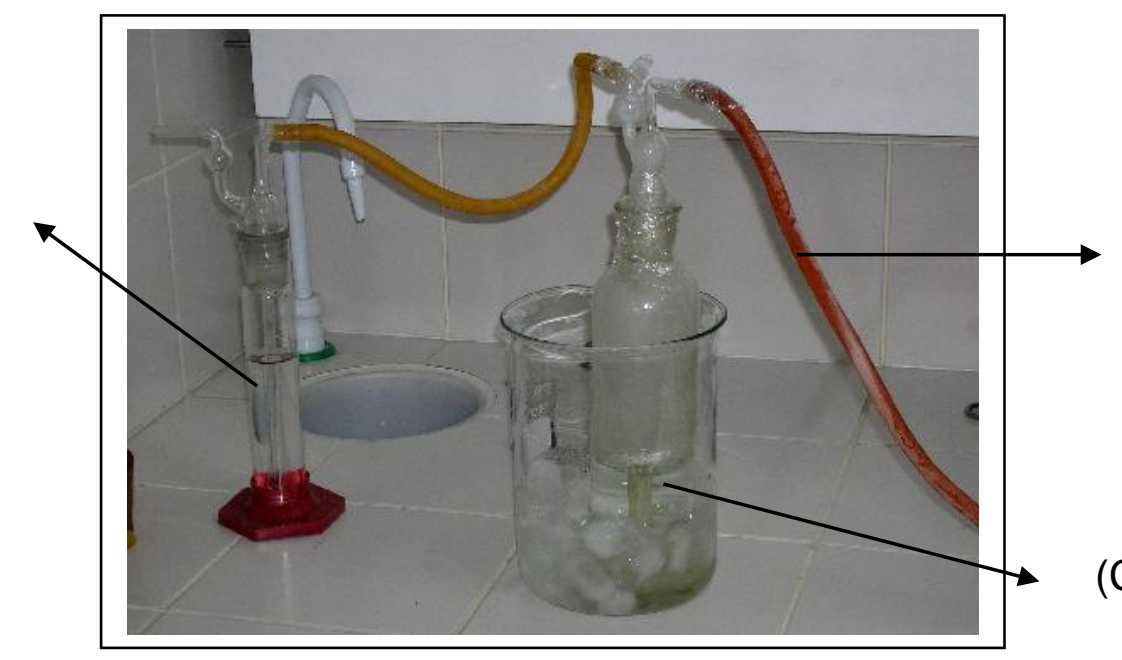

FIGURA 54 - Funcionamento do sistema proposto para a captura de $\mathrm{CO}_{2}$

Legenda:

(A) - Recipiente com indicador para detecção da presença de amônia.

(B) - Entrada de $\mathrm{CO}_{2}$ no sistema.

(C) - Recipiente borbulhador contendo hidróxido de amônio.

Fez-se um borbulhamento de $\mathrm{CO}_{2}$, diretamente de um cilindro em soluções de hidróxido de amônio $\left(\mathrm{NH}_{4} \mathrm{OH}\right)$ concentrado e em solução 1:1 com água destilada, em temperatura ambiente.

Esse procedimento provou a formação do bicarbonato de amônio, atendendo ao pretendido no trabalho. 


\section{2. Sistema gaseificação-sequestro de $\mathrm{CO}_{2}$ em escala laboratorial}

\section{2. 1. Procedimento}

1. A biomassa escolhida para ser usada no sistema de gaseificação laboratorial foi o bagaço de cana-de-açúcar.

2. A biomassa foi passada quatro vezes pelo triturador de resíduos orgânicos TRAPP TR 200, mostrado na fotografia da FIG. 55 a seguir:

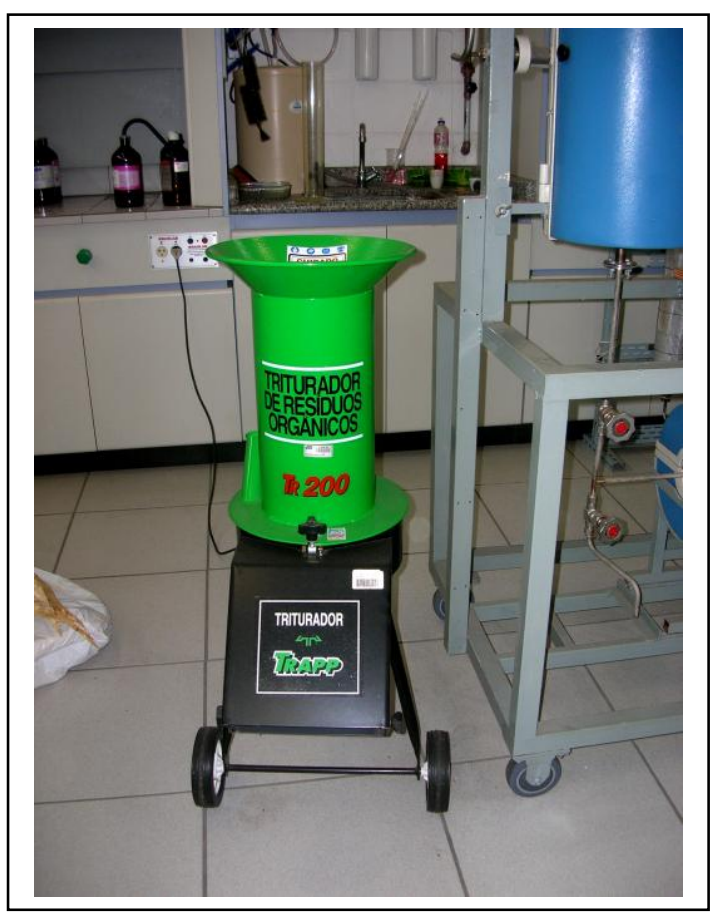

FIGURA 55 - Triturador utilizado na moagem do bagaço de cana-de-açúcar.

3. Em seguida, a biomassa foi deixada numa estufa, por 24 horas para que se retirasse o máximo da umidade presente.

4. A biomassa foi então passada por uma peneira Mesh 14, de forma a que adquirisse uma granulometria menor que a obtida após sair do triturador. 
Na FIG. 56 são mostradas duas fotografias das granulometrias que foram obtidas, após passar a biomassa pelo triturador (A) e após haver passado pela peneira (B).

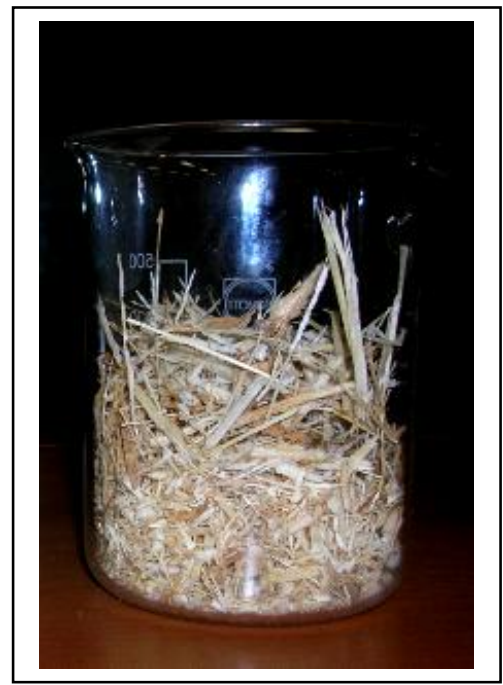

(A)

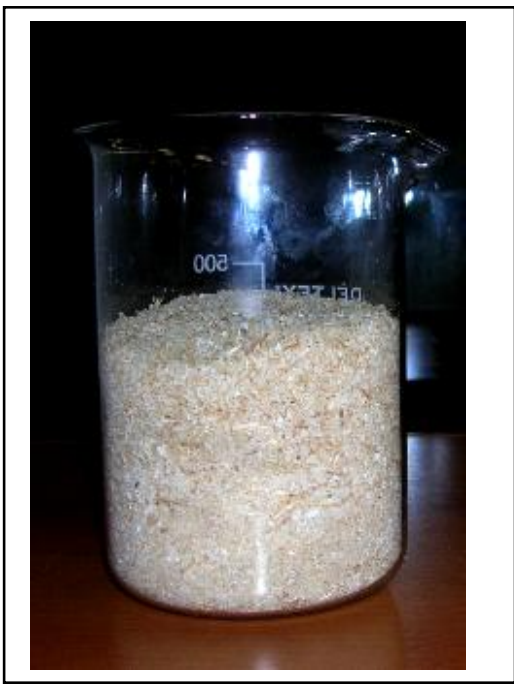

(B)

FIGURA 56 - Granulometrias obtidas da biomassa após passar pelo triturador (A) e após passar pela peneira Mesh 14 (B).

5. A seguir a biomassa foi pesada em uma balança analítica antes de ser colocada no sistema laboratorial.

6. Os procedimentos (1) a (5) foram repetidos nas quatro vezes em que se fez a gaseificação.

Na FIG 57 é mostrada uma fotografia do sistema utilizado para realizar a gaseificação da biomassa e a retenção do gás carbônico em hidróxido de amônio. 


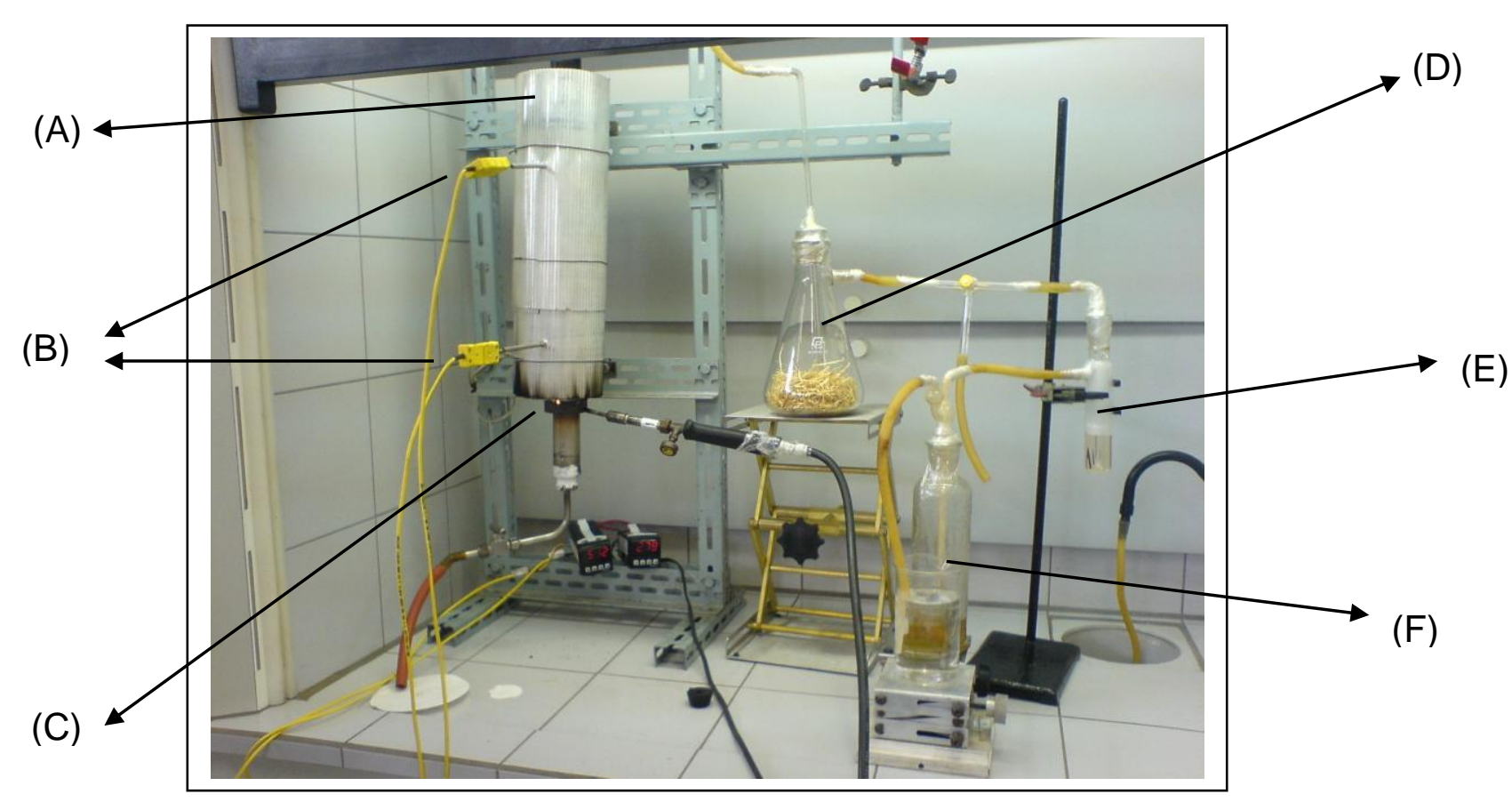

FIGURA 57 - Esquema da aparelhagem para gaseificação da biomassa com captura de $\mathrm{CO}_{2}$ e produção do fertilizante.

Legenda:
(A) - Gaseificador
(B) - Termopares
(C) - Fonte de calor
(D) - Adsorvedor de líquidos
(E) - Primeiro frasco lavador contendo hidróxido de amônio: água - $1: 1$
(F) - Segundo frasco lavador contendo hidróxido de amônio: água - $1: 1$

\section{3. Apuração das quantidades de resíduos agrícolas brasileiros}

Para que se efetuem os cálculos das quantidades de resíduos possíveis de ser gerados durante o processo de gaseificação da biomassa acima citado, usaram-se os índices disponíveis na literatura (Souza, 2002 e Bernardi, 2009) que estão apresentados na TAB 23. 
TABELA 23 - Resíduos disponíveis de culturas de biomassa no país e sua relação produto/resíduo.

\begin{tabular}{ccc}
\hline Cultura & Tipo de resíduo & $\begin{array}{c}\text { Relação } \\
\text { Produto/Resíduo }\end{array}$ \\
\hline Amendoim & Noz & 1,08 \\
Algodão & Rama & 2,45 \\
Soja & Palha & 1,40 \\
Feijão & Palha & 3,67 \\
Mandioca & Folhas & 0,19 \\
Coco da baia & Casca & 0,60 \\
Castanha de caju & Casca & 0,73 \\
Trigo & Palha & 1,42 \\
Madeira & Pedaços no campo & 0,17 \\
Milho & Palha & 1,42 \\
Arroz & Palha e Casca & 1,49 \\
Cana-de-açúcar & Palhada e bagaço & 0,28 \\
\hline
\end{tabular}

Nas FIG. 58 a 62 apresentam-se as quantidades de resíduos agrícolas disponíveis na literatura, por estado de cada região do Brasil, empregando-se os índices presentes na TAB. 23 aplicados sobre os valores da produção agrícola do ano de 2007, de cada região do país. 


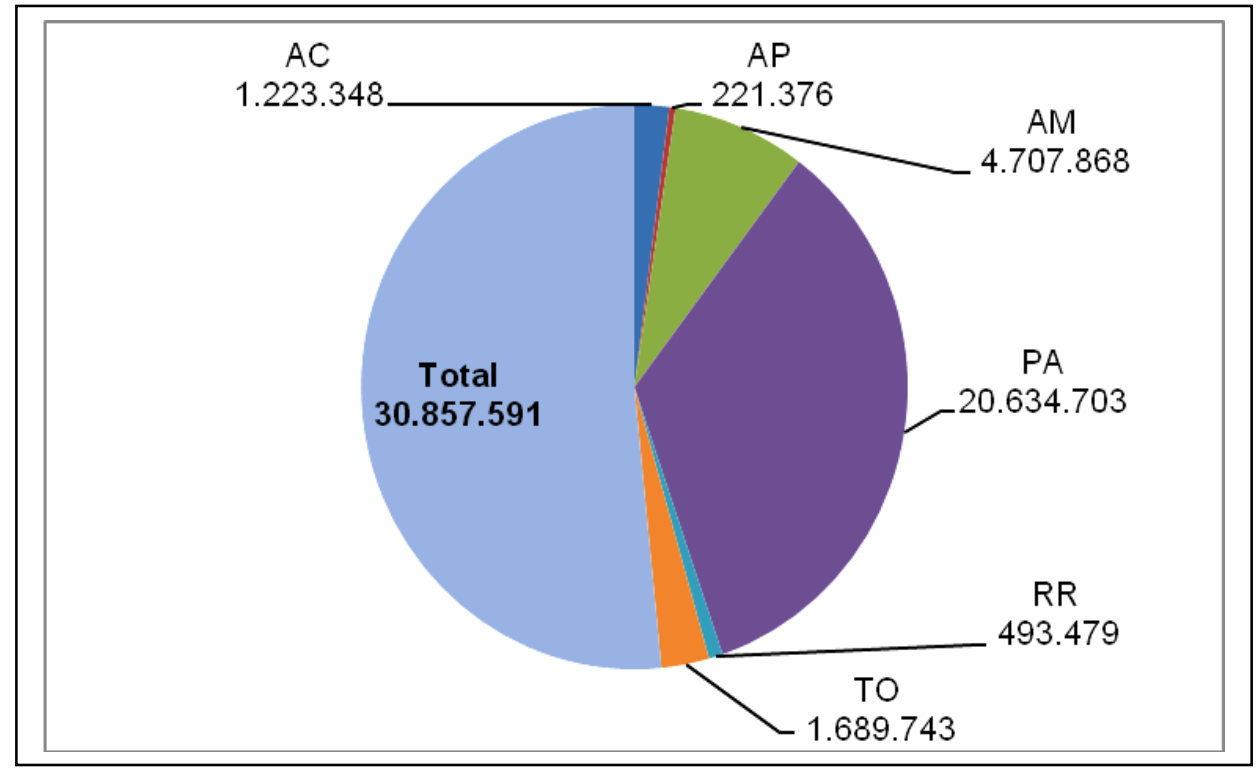

(A)

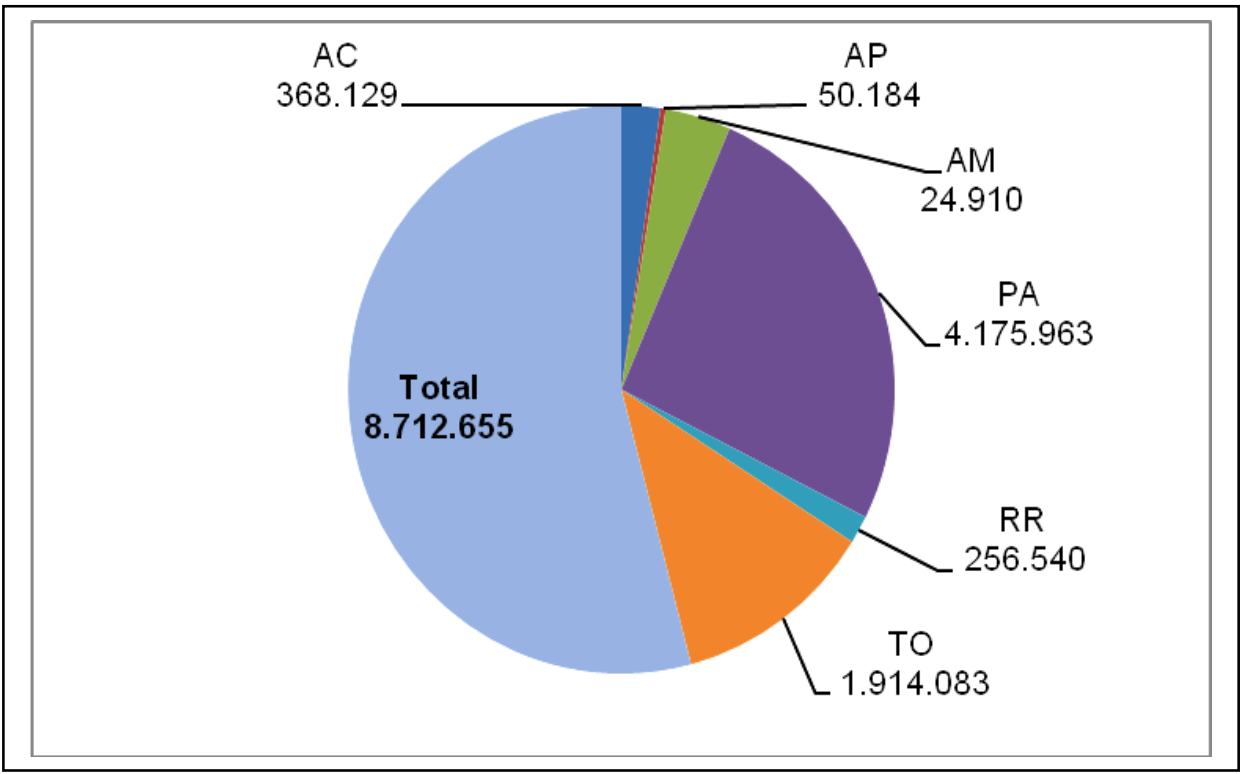

(B)

FIGURA 58 - Produção das culturas disponíveis da REGIÃO NORTE (N), por estados e em toneladas.

Em (A) está indicada a produção total anual.

Em (B) está indicada a quantidade de resíduos anuais. 


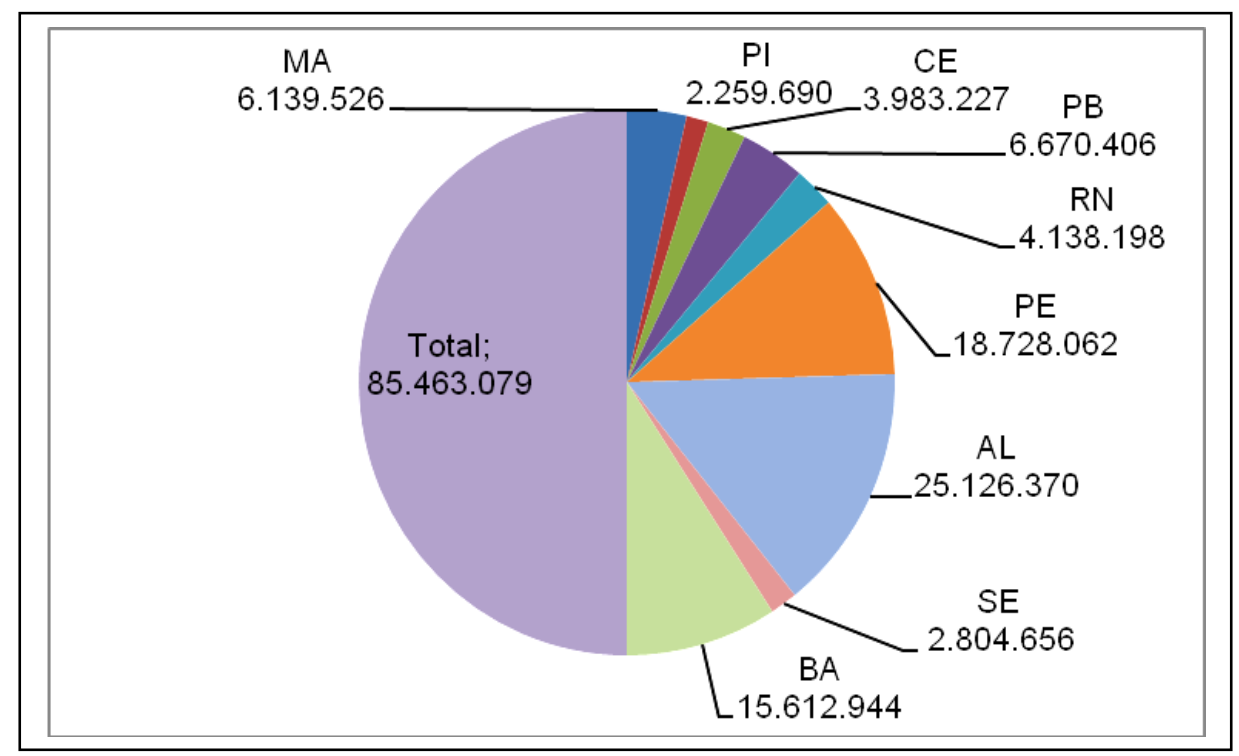

(A)

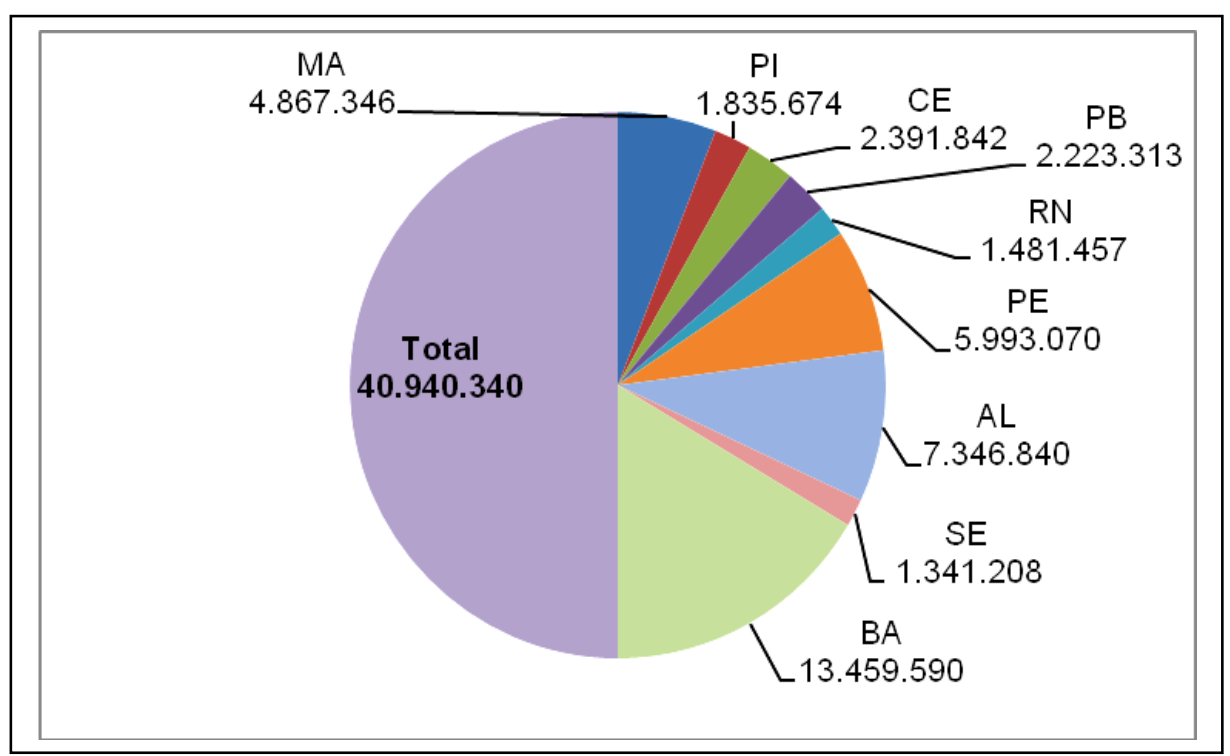

(B)

FIGURA 59 - Produção das culturas disponíveis da REGIÃO NORDESTE (NE), por estados e em toneladas.

Em (A) está indicada a produção total anual.

Em (B) está indicada a quantidade de resíduos anuais. 


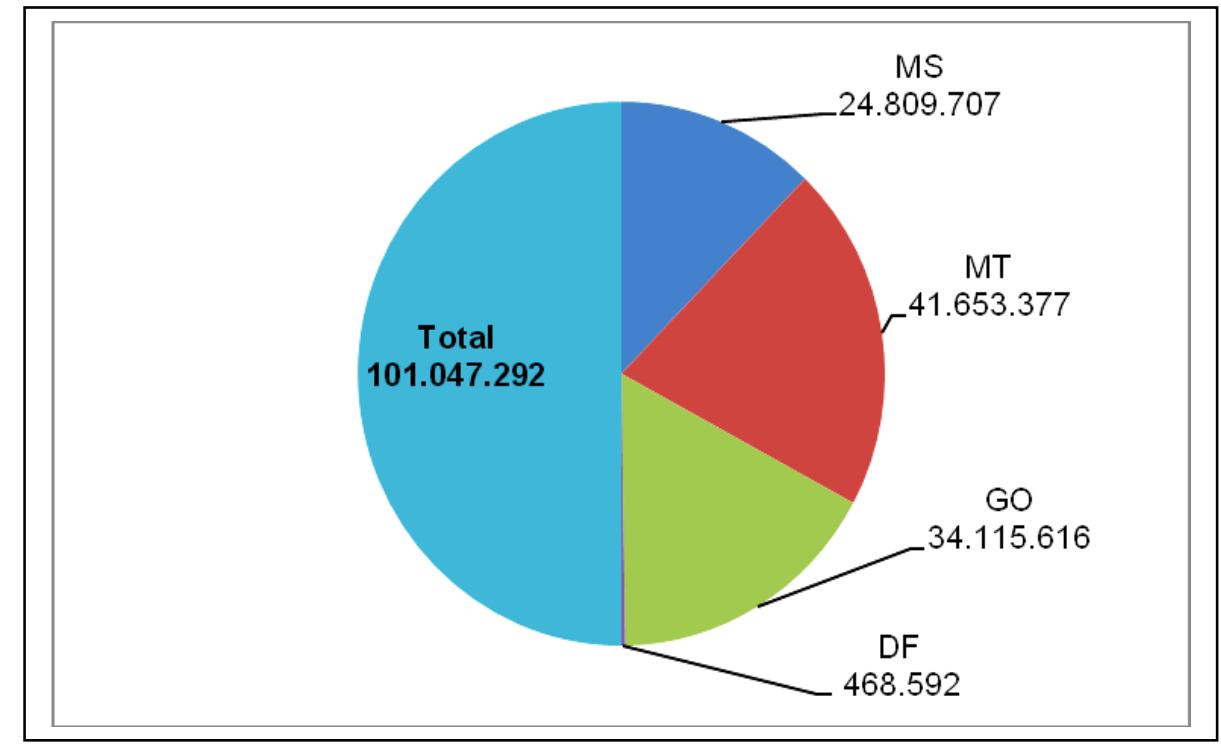

(A)

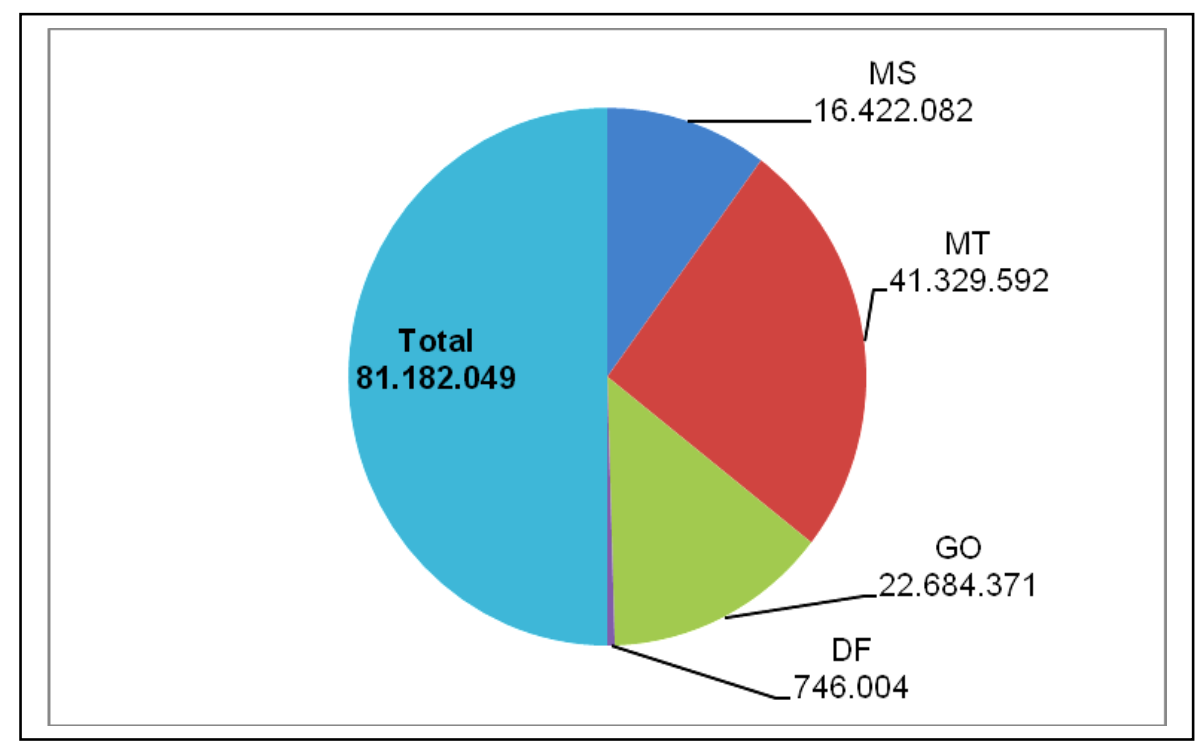

(B)

FIGURA 60 - Produção das culturas disponíveis da REGIÃO CENTRO OESTE (CO), por estados e em toneladas.

Em (A) está indicada a produção total anual.

Em (B) está indicada a quantidade de resíduos anuais. 


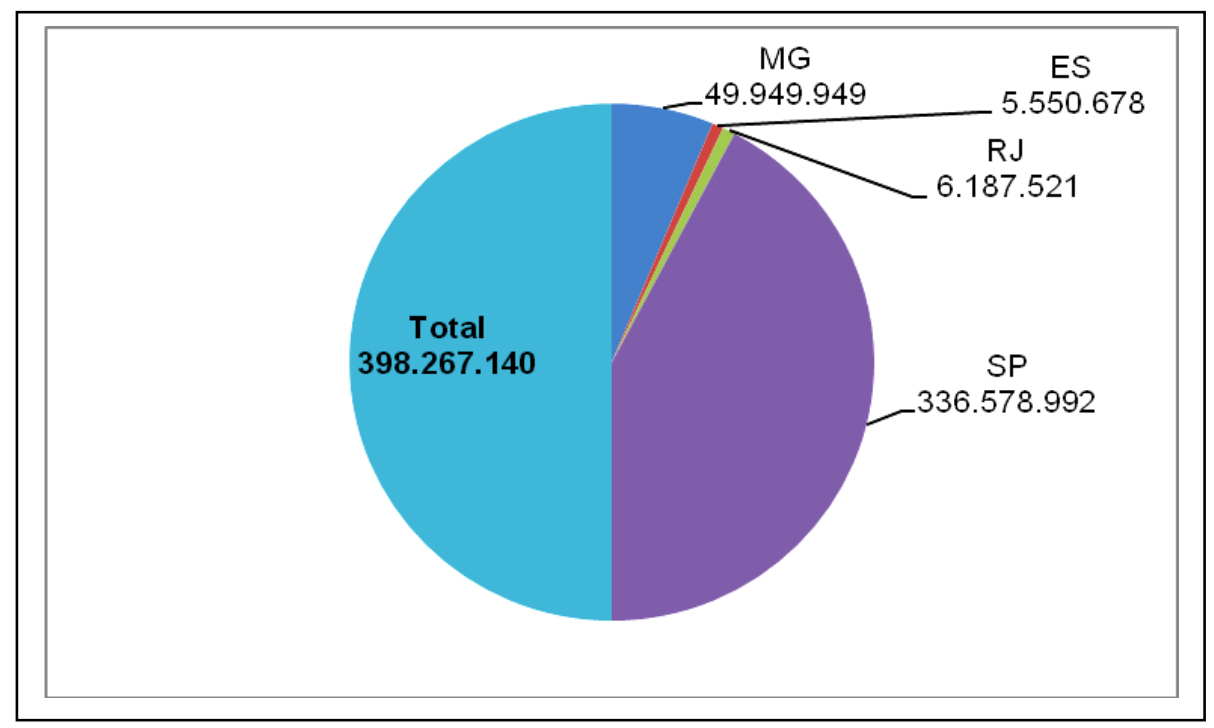

(A)

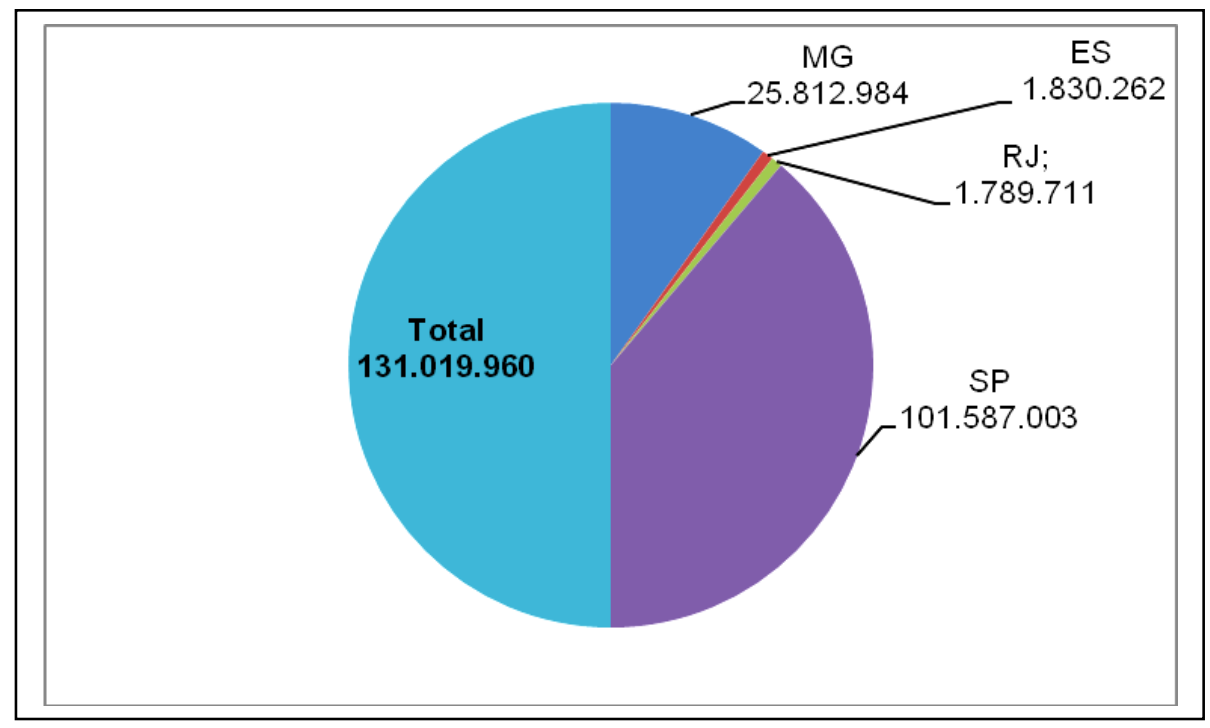

(B)

FIGURA 61 - Produção das culturas disponíveis da REGIÃO SUDESTE (SE), por estados e em toneladas.

Em (A) está indicada a produção total anual.

Em (B) está indicada a quantidade de resíduos anuais. 


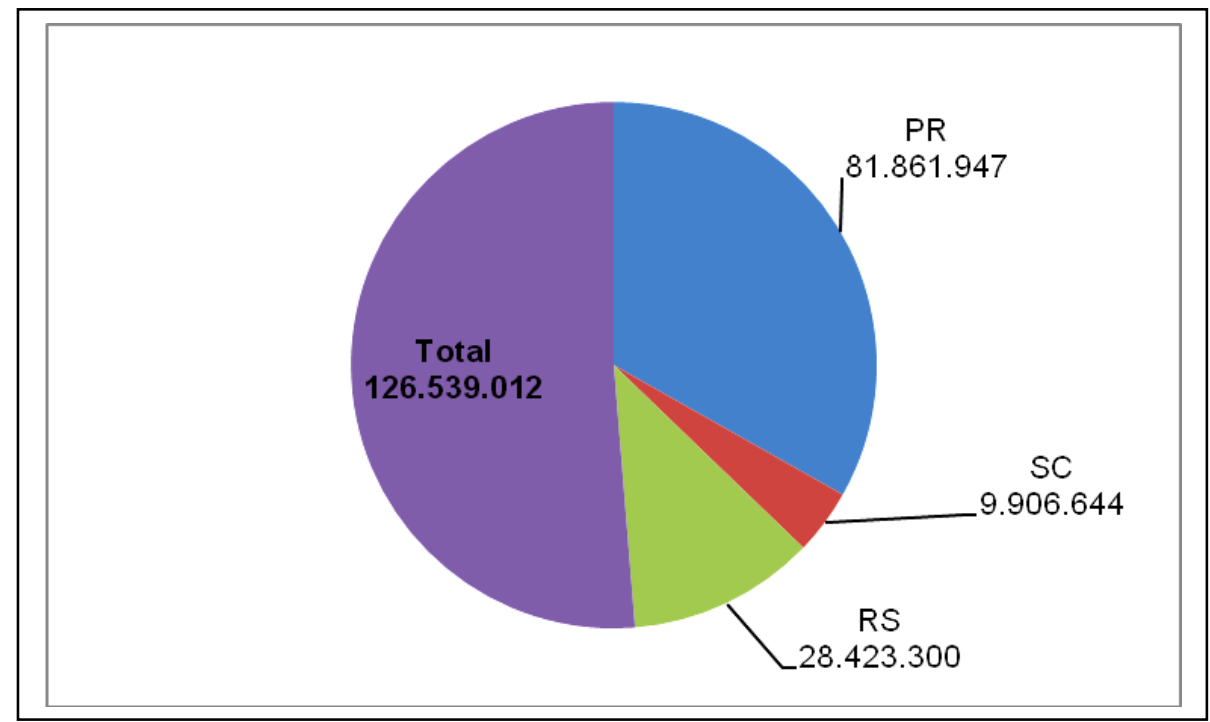

(A)

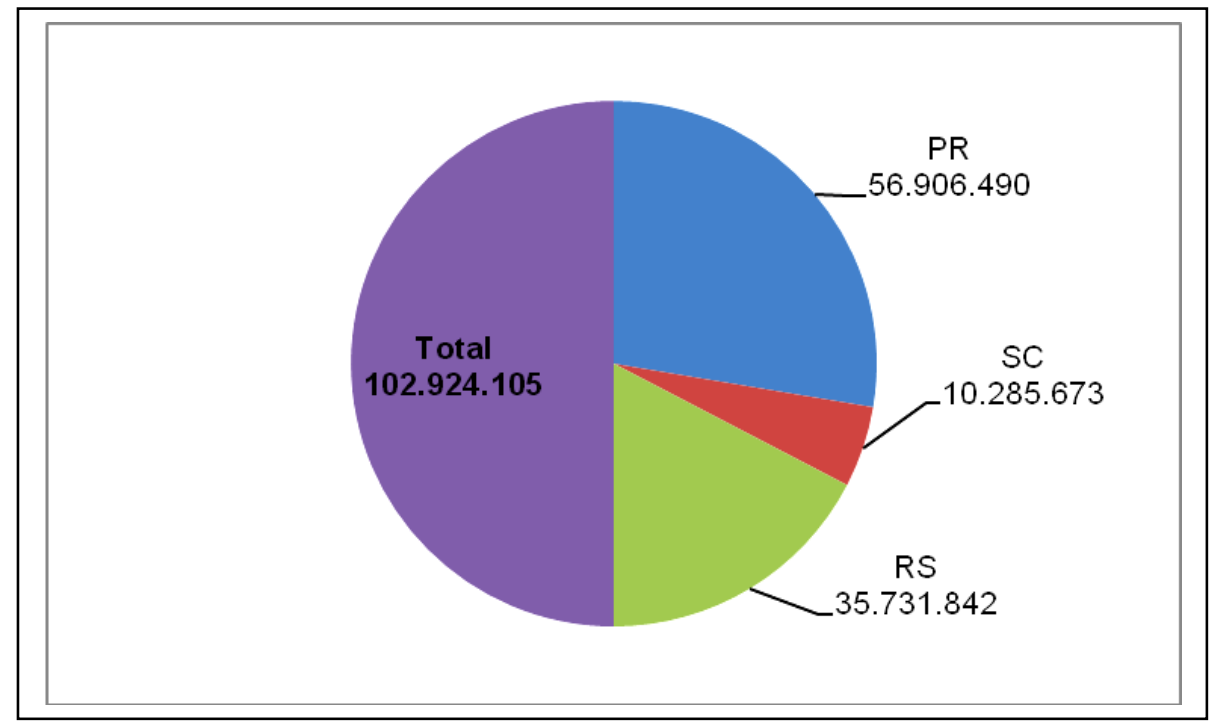

(B)

FIGURA 62 - Produção das culturas disponíveis da REGIÃO SUL (S), por estados e em toneladas.

Em (A) está indicada a produção total anual.

Em (B) está indicada a quantidade de resíduos anuais. 
Dessa forma, apresenta-se, na FIG. 63 a seguir, a quantidade total de resíduos de biomassa que poderia ser gerada a partir das culturas disponíveis.

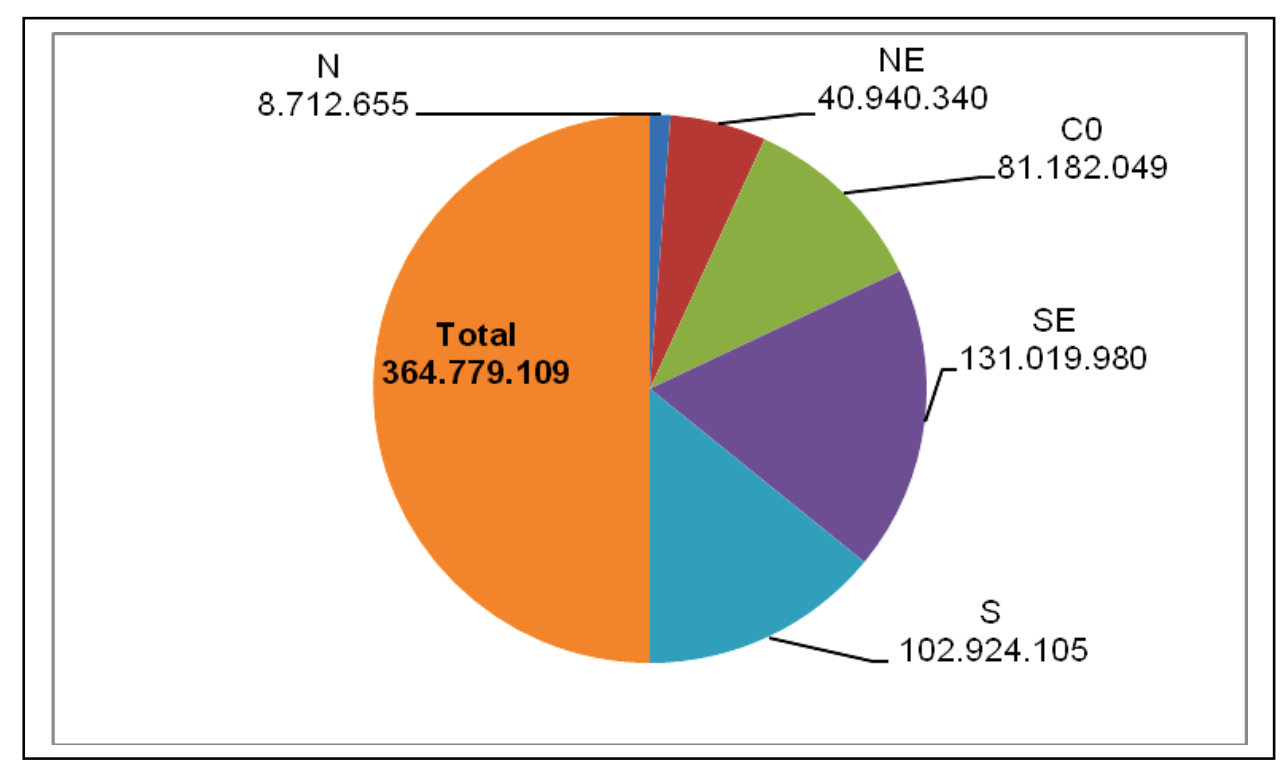

FIGURA 63 - Produção total, em toneladas, de resíduos de biomassa das culturas disponíveis nas regiões brasileiras.

Pelo observado na FIG. 63, deduz-se que estarão disponíveis mais de 364 milhões de toneladas de resíduos de biomassa, podendo estes ser aproveitados ao que este trabalho se propõe: a gaseificação, o sequestro de $\mathrm{CO}_{2}$ e a produção do fertilizante bicarbonato de amônio.

O escopo deste trabalho, ainda considerará o valor percentual de $25 \%$ (b) de $\mathrm{CO}_{2}$, que, segundo Gao (2008) e Li (2008) é o percentual com que se obtém a maior quantidade desse gás em um gaseificador com reforma. Esse valor é o ideal para um melhor aproveitamento na quantificação de créditos de carbono e na produção de bicarbonato de amônio. Na TAB. 24 apresentam-se os parâmetros obtidos por GAO com o uso de um gaseificador de biomassa com reforma a vapor. 
TABELA 24 - Parâmetros obtidos com o uso do gaseificador de biomassa com reforma.

\begin{tabular}{cc}
\hline Temperatura da gaseificação e reforma & $850{ }^{\circ} \mathrm{C}$ \\
Taxa de abastecimento de biomassa seca & $0,44 \mathrm{~kg} / \mathrm{h}$ \\
Taxa de abastecimento de vapor & $0,67 \mathrm{~kg} / \mathrm{h}$ \\
Densidade do gás obtido & $0,63 \mathrm{~kg} / \mathrm{m}^{3}$ \\
Quantidade de gás obtido (a) & $\begin{array}{r}2,51 \mathrm{~m}^{3} / \mathrm{kg} \text { de } \\
\text { biomassa }\end{array}$ \\
\hline Quantidade de $\mathrm{CO}_{2}$ no gás obtido & $\begin{array}{r}1,18 \mathrm{~kg} / \mathrm{kg} \mathrm{de} \\
\text { biomassa }\end{array}$ \\
\hline
\end{tabular}

Como é indicado na TAB 24, pode-se perceber que a quantidade de $\mathrm{CO}_{2}$ produzido para cada quilo de biomassa gaseificada é de1,18 $\mathrm{kg}$ valor esse que será aplicado sobre o valor total de biomassa disponível para gaseificação.

Considerações sobre o valor $1,18 \mathrm{~kg}$ obtido:

- sabe-se que a quantidade total de gás obtido é de $2,51 \mathrm{~m}^{3}$ (a);

- sabe-se que desse total, apenas $25 \%$ (b) correspondem ao $\mathrm{CO}_{2}$, levando-se a deduzir que há $0,63 \mathrm{~m}^{3}$ desse gás;

- sabe-se que a densidade do $\mathrm{CO}_{2}$, em temperatura ambiente, é igual a $1,87 \mathrm{~kg} / \mathrm{m}^{3}$ (c);

- infere-se, então, que a quantidade de $\mathrm{CO}_{2}$ no gás obtido é de 1,18 kg por cada quilo de biomassa. 


\section{RESULTADOS E DISCUSSÃO}

\subsection{Síntese e caracterização do bicarbonato de amônio}

Inicialmente fez-se um borbulhamento de $\mathrm{CO}_{2}$ em soluções de hidróxido de amônio $\left(\mathrm{NH}_{4} \mathrm{OH}\right)$ concentrado e em seguida em solução 1:1 com água destilada, em temperatura ambiente e pressão atmosférica, objetivando-se a formação do bicarbonato de amônio. Em ambos os casos os compostos se apresentaram de forma branca e cristalina.

Na FIG. 64 mostra-se a fotografia do frasco de reação, onde se observa a formação dos cristais do bicarbonato de amônio.

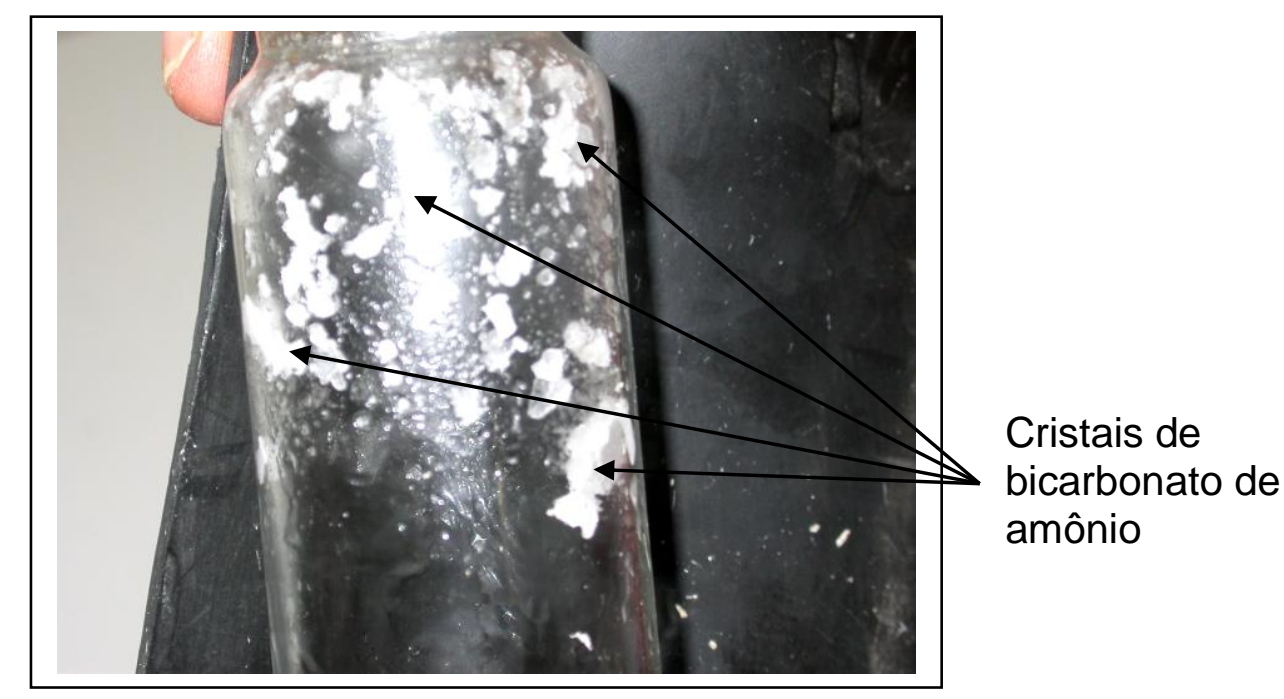

FIGURA 64 - Cristais de bicarbonato de amônio nas paredes do recipiente.

Para se comprovar a formação deste composto em um sistema de gaseificação, em uma segunda etapa fez-se a gaseificação de bagaço de canade-açúcar e recolheu-se o gás resultante da reação em hidróxido de amônio.

Foram realizadas quatro gaseificações conforme a tabulação de dados apresentados na TAB. 25 
TABELA 25 - Valores indicados na gaseificação do bagaço de cana-de-açúcar em escala laboratorial.

\begin{tabular}{|c|c|c|c|}
\hline & $\begin{array}{c}\text { Massa da } \\
\text { biomassa (g) }\end{array}$ & $\begin{array}{c}\text { Temperatura } \\
\text { inicial (o } \mathrm{C}) \\
\end{array}$ & $\begin{array}{l}\text { Temperatura } \\
\text { final }\left({ }^{\circ} \mathrm{C}\right)\end{array}$ \\
\hline $1^{\circ}$ experimento & 28,45 & 45 & 638 \\
\hline $2^{\circ}$ experimento & 26,45 & 37 & 597 \\
\hline $3^{\circ}$ experimento & 35,67 & 46 & 579 \\
\hline $4^{\circ}$ experimento & 36,53 & 38 & 571 \\
\hline $\begin{array}{l}\text { Média dos dados } \\
\text { obtidos }\end{array}$ & $31,77 \mathrm{~g}$ & $41,5 \stackrel{\circ}{ } \mathrm{C}$ & $596,2^{\circ} \mathrm{C}$ \\
\hline
\end{tabular}

Os sais cristalizados obtidos nos processos foram filtrados e lavados com álcool etílico.

Aos compostos obtidos pelo borbulhamento denominou-se $\mathrm{NH}_{4} \mathrm{HCO}_{3}$ (borb.) e aos obtidos pela gaseificação denominou-se de bicarbonato da gaseificação (gas.).

Fez-se a secagem dos compostos, antes das análises de CHN, TG e DTA e do registro dos espectros de absorção na região do infravermelho e difração de Raios-X, deixando-se os mesmos em um dessecador, sob condições de vácuo.

Tanto pelo borbulhamento de $\mathrm{CO}_{2}$ de um cilindro como para o gás da gaseificação do bagaço de cana-de-açúcar, recebidos em solução de hidróxido de amônio, obtiveram-se compostos sólidos à temperatura ambiente, com aspecto cristalino, bastante higroscópico e de cor branca.

Por meio dos testes qualitativos de solubilidade constatou-se que o composto era solúvel em água e insolúvel em álcool, características do bicarbonato de amônio.

Todas as análises foram realizadas em triplicata, no Centro de Células a Combustível do IPEN-CNEN/SP. 


\section{2. Determinação de $\mathrm{C}, \mathrm{H}$ e N}

Determinaram-se os teores de carbono, nitrogênio e hidrogênio, empregando-se um instrumento microanalisador CHN, Perkin Elmer, Série 2 2400.

As análises $\mathrm{CHN}$ dos compostos obtidos pelo borbulhamento de $\mathrm{CO}_{2}$ foram muito semelhantes, portanto optou-se pela utilização daquele obtido em solução de hidróxido de amônio 1:1 para a apresentação do resultado da análise $\mathrm{CHN}$.

$\mathrm{O}$ valor encontrado para o $\mathrm{NH}_{4} \mathrm{HCO}_{3}$ (gas.) é uma média das amostras dos quatro experimentos. A porcentagem de oxigênio foi tirada por diferença.

Compararam-se os valores teóricos calculados com os obtidos por microanálise CHN, estando os resultados obtidos apresentados na TAB. 26.

TABELA 26 - Valor calculado e obtido por análise $\mathrm{CHN}$ do $\mathrm{NH}_{4} \mathrm{HCO}_{3}$

\begin{tabular}{ccc}
\hline $\mathrm{NH}_{4} \mathrm{HCO}_{3}$ (calc.) & $\mathrm{NH}_{4} \mathrm{HCO}_{3}$ (borb.) & $\mathrm{NH}_{4} \mathrm{HCO}_{3}$ (gas.) \\
\hline $\mathrm{C}=15,59 \%$ & $\mathrm{C}=15,19 \%$ & $\mathrm{C}=15,32 \%$ \\
$\mathrm{H}=6,38 \%$ & $\mathrm{H}=6,20 \%$ & $\mathrm{H}=6,08 \%$ \\
$\mathrm{~N}=17,72 \%$ & $\mathrm{~N}=18,10 \%$ & $\mathrm{~N}=17,39 \%$ \\
$\mathrm{O}=60,71 \%$ & $\mathrm{O}=60,11 \%$ & $\mathrm{O}=61,21 \%$ \\
\hline
\end{tabular}

A massa molar do bicarbonato de amônio é de 79,06 g.mol ${ }^{-1}$. Pelas análises $\mathrm{CHN}$ a massa molar dos compostos obtidos também se encontra em cerca de 79 g.mol ${ }^{-1}$.

Usando-se os dados encontrados pode-se supor que a estequiometria do composto seja mesmo a do bicarbonato de amônio: $\mathrm{CH}_{5} \mathrm{NO}_{3}$.

Tanto o $\mathrm{NH}_{4} \mathrm{HCO}_{3}$ obtido por borbulhamento direto de $\mathrm{CO}_{2}$ em hidróxido de amônio (borb.) como para o obtido pela gaseificação do bagaço de cana-deaçúcar (gas.) mostraram ser o mesmo composto.

Assim, para as análises seguintes utilizou-se somente o obtido por borbulhamento de $\mathrm{CO}_{2}$ em hidróxido de amônio. 


\section{3. Análise térmica TG/DTA}

A análise termogravimétrica (TG) é a técnica na qual a mudança da massa de uma substância é medida em função da temperatura enquanto ela é submetida a uma programação controlada.

A análise térmica diferencial (DTA - Differential Thermal Analysis) é a técnica na qual a diferença de temperatura entre uma substância e um material de referência é medida em função da temperatura quando ambos são submetidos a uma programação controlada de temperatura sendo realizada, na maioria das vezes, juntamente com a análise TG. Mostra processos físicos e químicos envolvendo variação de energia. Ao longo do programa de aquecimento as temperaturas da amostra e da referência se mantêm iguais até que ocorra alguma alteração física ou química na amostra.

Se a reação for exotérmica, a amostra irá liberar calor, ficando por um curto período de tempo, com uma temperatura maior que a referência. Do mesmo modo, se a reação for endotérmica a temperatura da amostra será temporariamente menor que a referência.

Segundo estudos experimentais realizados por J. E. House, 1980, na decomposição térmica do bicarbonato de amônio, é necessária uma energia de ativação de 10,6 kcal mol${ }^{-1}$.

As análises térmicas do composto $\mathrm{NH}_{4} \mathrm{HCO}_{3}$ obtido por borbulhamento direto de $\mathrm{CO}_{2}$, foram realizadas em uma Termobalança Setaram Labsys ${ }^{\mathrm{TM}}$, sob atmosfera dinâmica de ar sintético, com vazão de aproximadamente $40 \mathrm{~mL} \mathrm{~min}^{-1}$, utilizando-se cadinho de alumina.

A termodecomposição foi realizada com uma razão de aquecimento de $10^{\circ} \mathrm{Cmin}^{-1}$. As curvas DTA foram obtidas contra um cadinho de referência de alumina. As curvas TG e DTA foram subtraídas dos dados de uma análise em branco, empregando-se as mesmas condições operacionais e os mesmos cadinhos usados na termodecomposição.

As curvas TG/DTA obtidas estão apresentadas na FIG. 65 


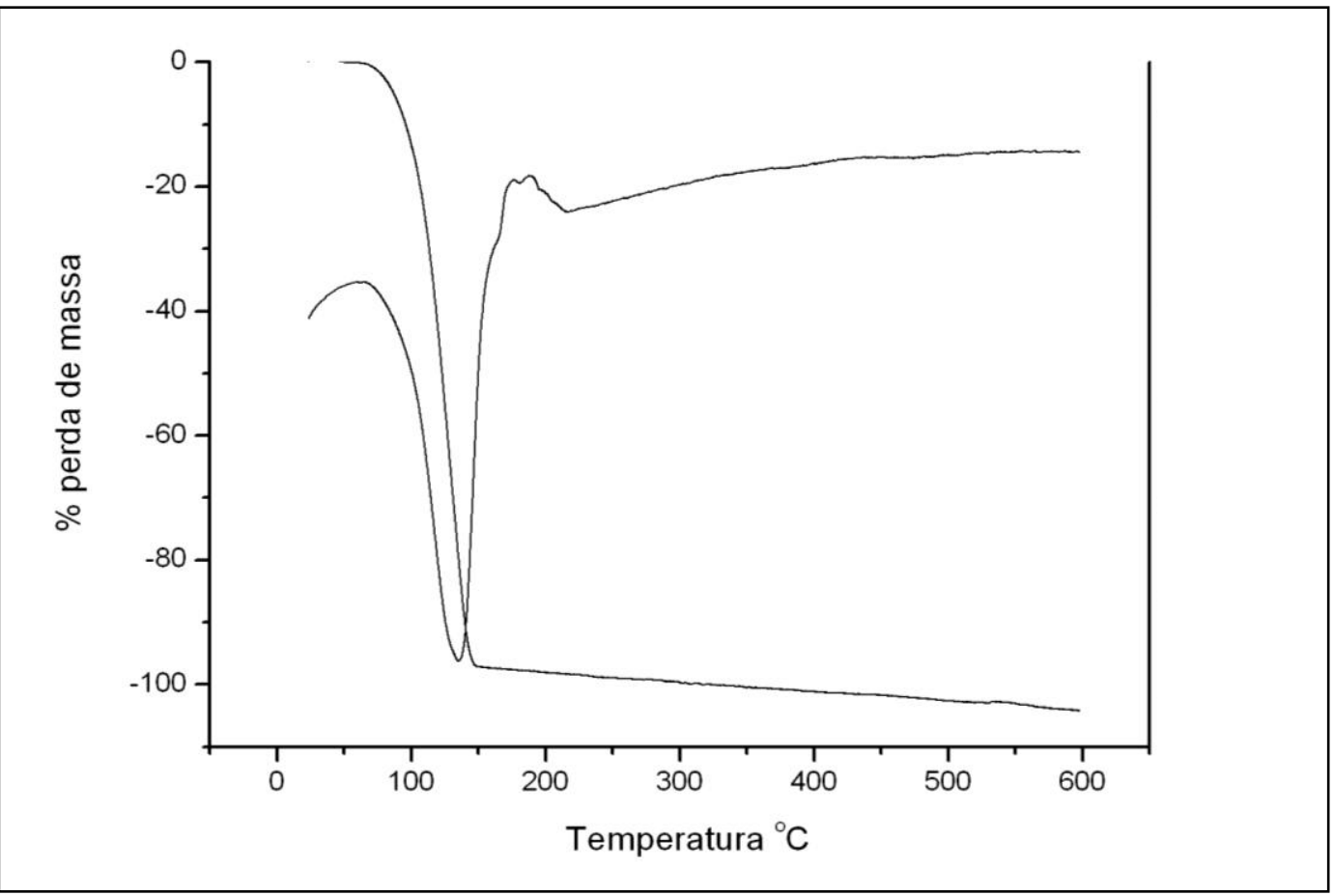

FIGURA 65 - Análise térmica do $\mathrm{NH}_{4} \mathrm{HCO}_{3}$ (borb,)

Observa-se pelas curvas presentes no gráfico TG e DTA, que a decomposição térmica do composto ocorre em um único evento endotérmico, que se inicia em cerca de $60^{\circ} \mathrm{C}$ e se conclui em cerca de $150{ }^{\circ} \mathrm{C}$.

Este comportamento está de acordo com a decomposição padrão do bicarbonato de amônio em $\mathrm{NH}_{3}, \mathrm{CO}_{2}$ e $\mathrm{H}_{2} \mathrm{O}$.

\section{4. Espectros de absorção na região do infravermelho}

A espectroscopia de absorção na região do infravermelho é uma técnica analítica que se baseia no fato de que as ligações químicas das substâncias possuem freqüências de vibração específicas, as quais correspondem a níveis de energia da molécula. Ao se fazerem medidas em uma amostra, um raio monocromático de luz infravermelha é passado pela amostra e a quantidade de energia transmitida é registrada. O gráfico construído deve indicar o comprimento 
de onda, em $\mathrm{cm}^{-1}$, no eixo das abscissas e a transmitância, em \%, no eixo das ordenadas.

Nas análises de espectro de absorção na região do infravermelho do composto $\mathrm{NH}_{4} \mathrm{HCO}_{3}$ obtido por borbulhamento direto de $\mathrm{CO}_{2}$, foram registrados os espectros com técnica de transmissão, na região de 4000 a $400 \mathrm{~cm}^{-1}$, do sal cristalizado a partir da reação do dióxido de carbono com a solução aquosa de hidróxido de amônio. Foi empregado um espectrômetro Nicolet FTIR-8100 com detector DTGS-KBr com as amostras suportadas em matrizes de brometo de potássio.

$\mathrm{O} \mathrm{KBr}$ usado nas matrizes foi previamente tratado termicamente a $400{ }^{\circ} \mathrm{C}$ por duas horas em atmosfera de ar seco e armazenado em dessecador sobre cloreto de cálcio anidro. Na FIG. 66 é apresentado o espectro de absorção na região do infravermelho do composto obtido apenas pelo borbulhamento em hidróxido de amônio (borb.).

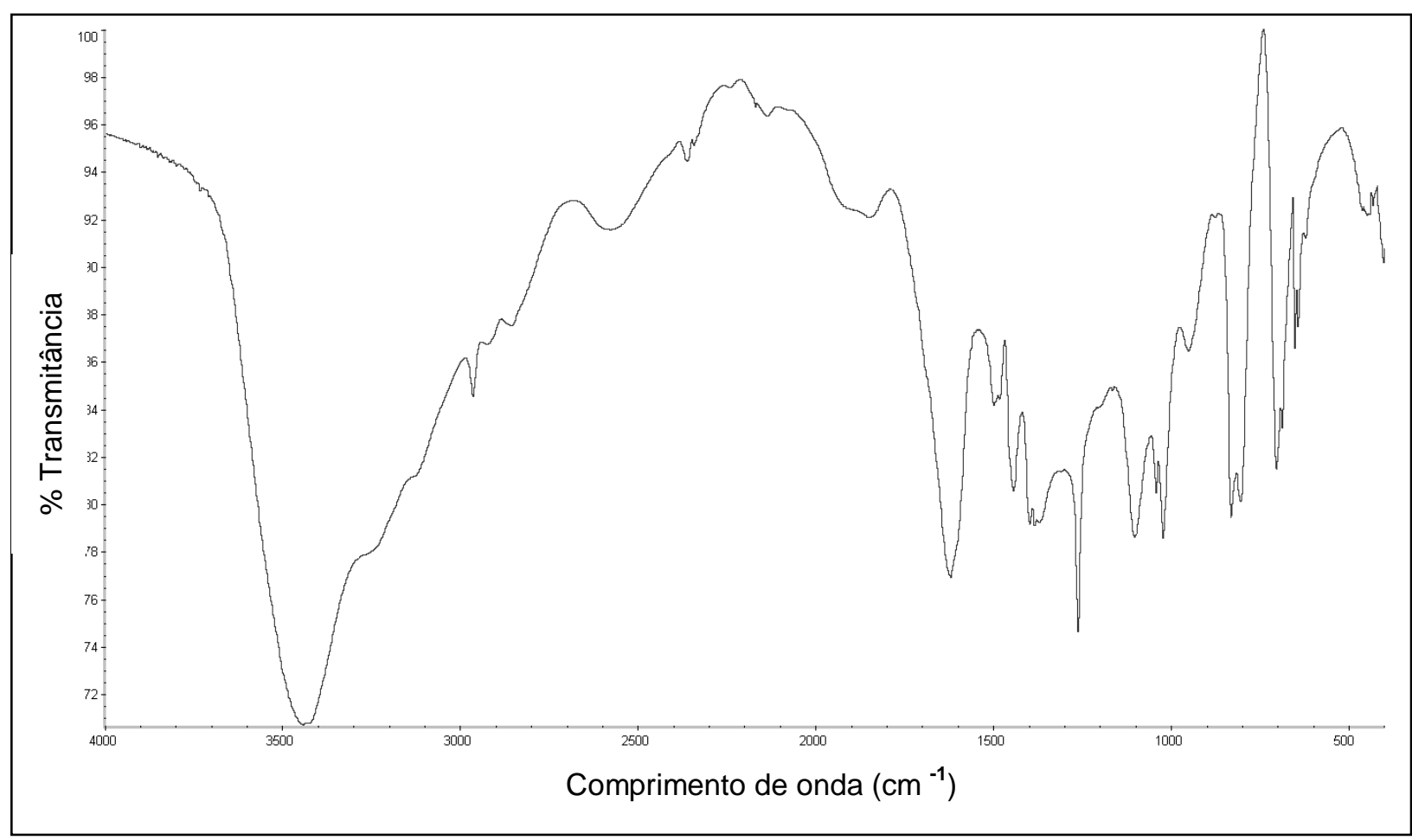

FIGURA 66 - Espectro de absorção na região do infravermelho do composto $\mathrm{NH}_{4} \mathrm{HCO}_{3}$ (borb.) registrado em matriz de $\mathrm{KBr}$. 
$\mathrm{Na}$ figura, podem ser observadas as bandas atribuídas ao estiramento assimétrico $\mathrm{CO}\left(\mathrm{v}_{(\text {as })} \mathrm{CO}\right) \mathrm{em} 1258 \mathrm{~cm}^{-1}$.

A banda correspondente ao estiramento simétrico $\mathrm{CO}\left(\mathrm{v}_{(\mathrm{s})} \mathrm{CO}\right)$, que normalmente é observada na região de $1600 \mathrm{~cm}^{-1}$, não pode ser claramente atribuída devido à presença de umidade no sal, uma vez que o bicarbonato de amônio é altamente higroscópico.

As bandas atribuídas aos modos vibracionais característicos da rede tetraédrica do íon amônia podem ser observadas na região de 3200 a $1400 \mathrm{~cm}^{-1}$ $\left(1400,1680,3040,3145 \mathrm{~cm}^{-1}\right.$, segundo K. Nakamoto) ${ }^{319}$.

Essas bandas podem ser comparadas com o espectro padrão de absorção na região de infravermelho do bicarbonato de amônio, registradas em estudos de K. Nakamoto 1986, conforme mostrado na FIG. 67.

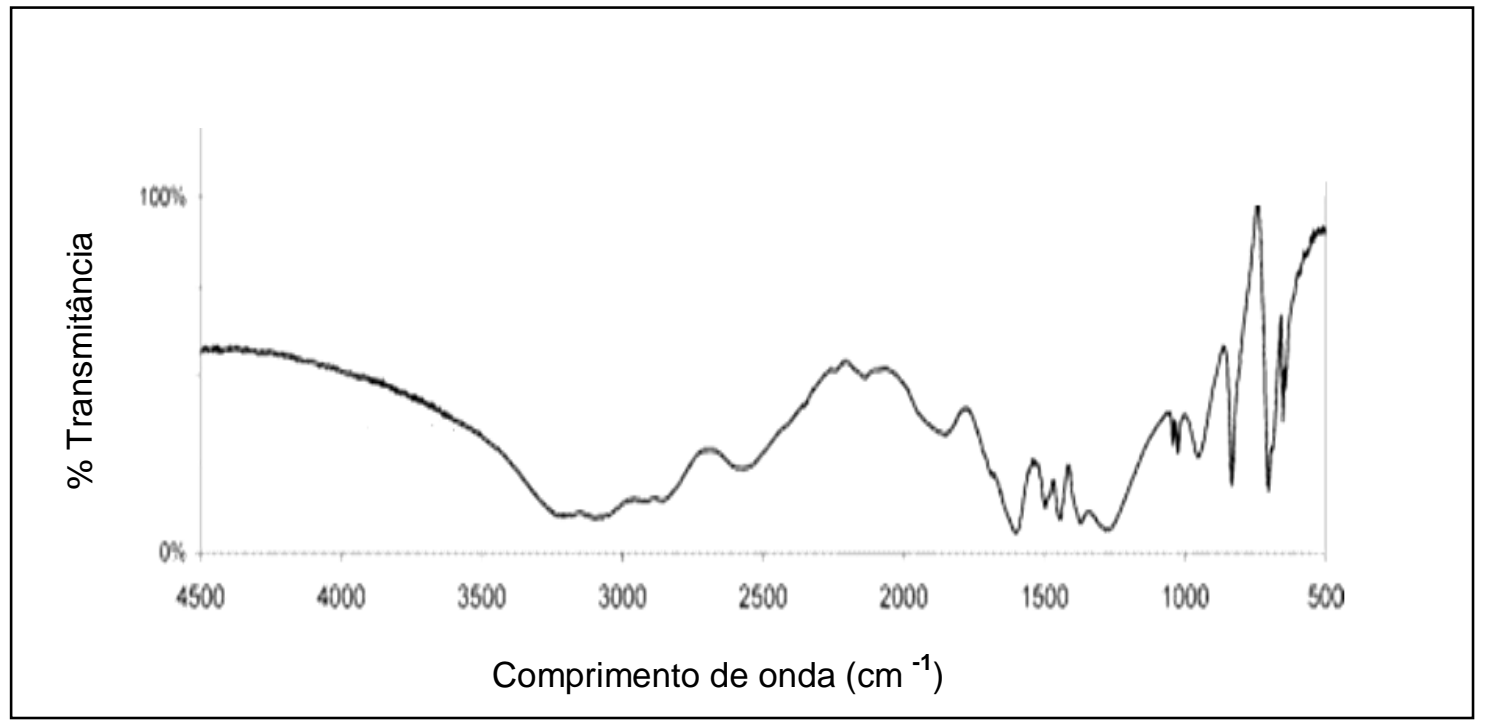

FIGURA 67 - Espectro padrão de absorção na região do infravermelho do bicarbonato de amônio.

\section{5. Espectros de difração de raios $X$ (método do pó)}

A difratometria de raios $X$ é a principal técnica de caracterização de materiais cristalinos. Nela utiliza-se uma pequena quantidade de amostra (pó), finamente dividido, permitindo a identificação de materiais com relação às suas características cristalinas, como o isomorfismo ao longo de uma série e a determinação da pureza em uma amostra. 
Os raios $\mathrm{X}$ atingem o material e espalham-se elasticamente, sem perda de energia pelos elétrons de um átomo. $O$ fóton de raios $X$ colide com o elétron, muda sua trajetória mas mantém a mesma fase e energia do fóton incidente. Do ponto de vista da física, a onda eletromagnética é instantaneamente absorvida pelo elétron e reemitida e cada elétron atua como centro de emissão de raios $X$.

A análise de difração de raios $\mathrm{X}$ (DRX) do composto $\mathrm{NH}_{4} \mathrm{HCO}_{3}$ obtido por borbulhamento direto de $\mathrm{CO}_{2}$ foi efetuada em um difratômetro de raios $\mathrm{X}$ de mesa, maca Rigaku, modelo MiniFlex II, usando uma fonte de radiação CuK $\alpha$ ( $\lambda=$ $1,540562 \AA, \mu / \rho=60,6)$ na modalidade passo com $2 \theta$ variando entre $20^{\circ}$ e $60^{\circ}$ usando um incremento $2 \theta=0,0^{\circ}$ a cada dois segundos de contagem potencial de saída do tubo fixa em $30 \mathrm{kV}$ e corrente de saída do tubo fixa em 15mA.

Na FIG. 68 é mostrado o espectro de difração de Raios X, pelo método do pó.

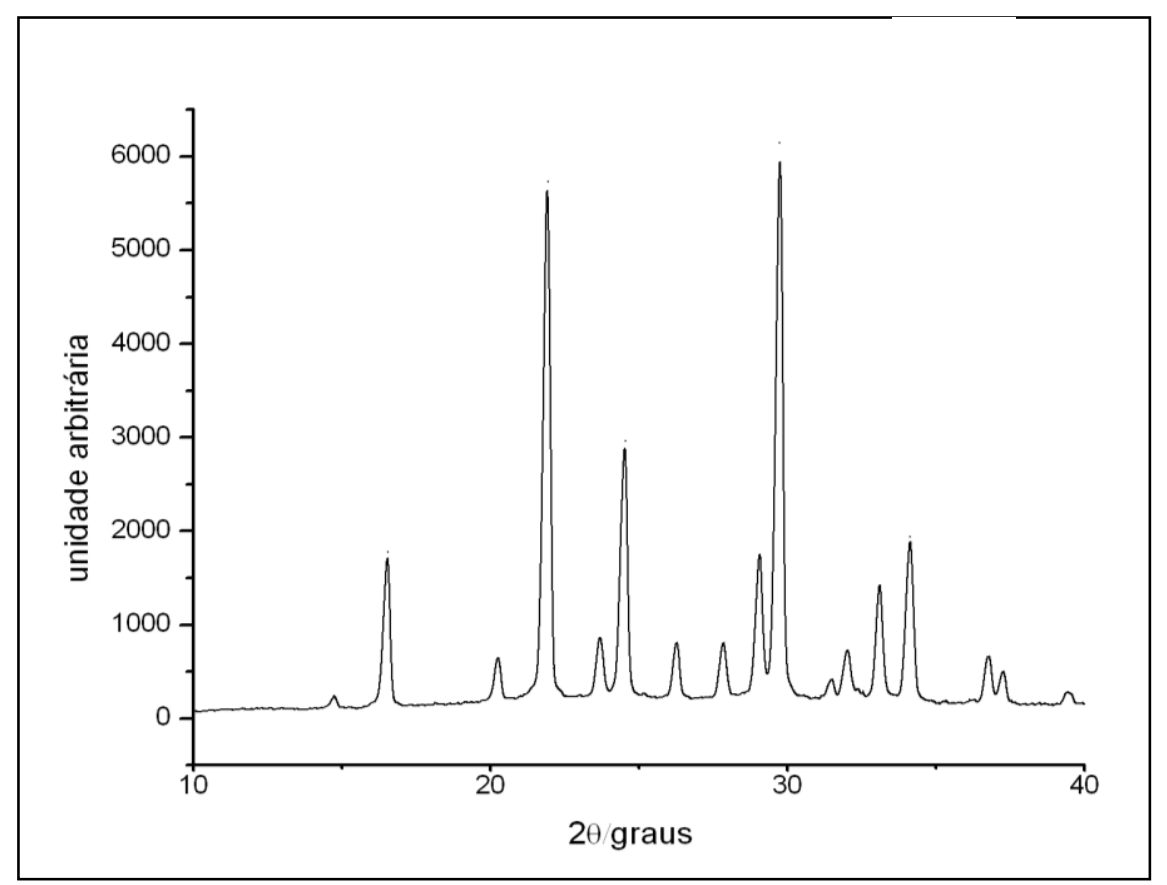

FIGURA 68 - Difratograma de Raios X (método do pó) do composto obtido pelo borbulhamento de $\mathrm{CO}_{2}$ sobre solução aquosa de hidróxido de amônio. 
Observam-se no difratograma de Raios $X$, picos para $2 \theta$ igual a $16,5^{\circ}$, $22,0^{\circ}$ e $29,7^{\circ}$, que são atribuídos à estrutura cristalina do bicarbonato de amônio 317

Todas as análises instrumentais realizadas, assim como os resultados das análises elementares permitem concluir que o sal obtido é o bicarbonato de amônio.

Estes picos podem ser encontrados em um difratograma padrão para 0 bicarbonato de amônio, segundo estudos de Cheng e Pan, 2007, conforme mostrado na FIG. 69.

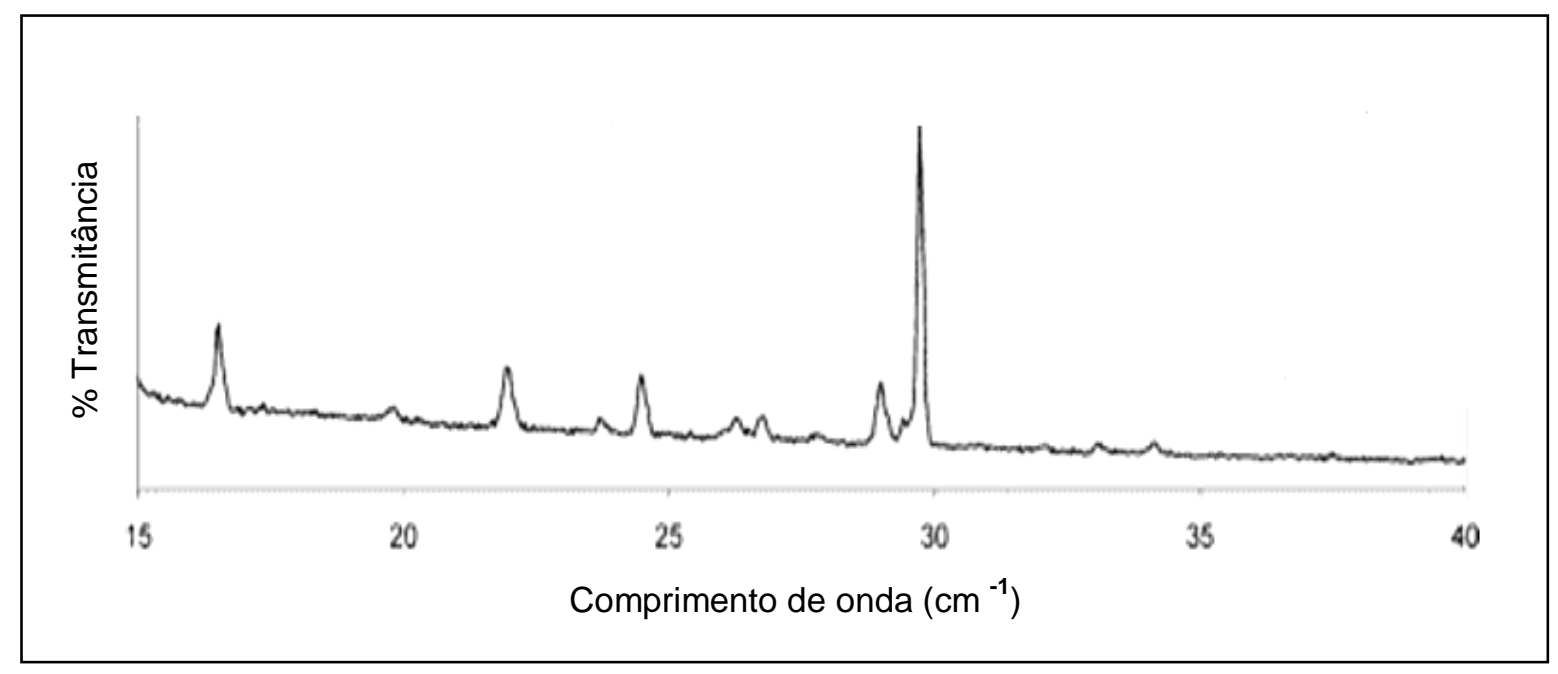

FIGURA 69 - Espectro padrão de difração de raios X do bicarbonato de amônio

\section{6. Estimativa da quantidade de $\mathrm{CO}_{2}$ e do fertilizante em função da produção de resíduos da agricultura brasileira}

$\mathrm{Na}$ TAB 27 apresenta-se a quantidade de $\mathrm{CO}_{2}$ que pode ser produzida com a gaseificação e reforma a vapor da biomassa, para posterior utilização na produção do fertilizante bicarbonato de amônio.

Para isso, multiplicou-se a quantidade de resíduos dessa biomassa pelo valor 1,18 , conforme indicado na metodologia. 
TABELA 27 - Produção de $\mathrm{CO}_{2}$ por região - Dezembro 2007

\begin{tabular}{ccc}
\hline Região & $\begin{array}{c}\text { Quantidade de } \\
\text { resíduos anual(t) }\end{array}$ & $\begin{array}{c}\text { Quantidade de } \mathbf{C O}_{2} \\
(\mathbf{t})\end{array}$ \\
\hline Norte & 8.712 .655 & 10.280 .932 \\
Nordeste & 40.940 .340 & 48.309 .601 \\
Centro Oeste & 81.182 .049 & 95.794 .817 \\
Sudeste & 131.019 .960 & 154.603 .552 \\
Sul & 102.924 .105 & 121.450 .443 \\
\hline Total & $\mathbf{3 6 4 . 7 7 9 . 1 0 9}$ & $\mathbf{4 3 0 . 4 3 9 . 3 4 8}$ \\
\hline
\end{tabular}

Aplicando-se sobre a quantidade total de $\mathrm{CO}_{2}$ obtida na tabela 27 e considerando-se que a perda que ocorre durante a reação, que segundo Bai (1997), está em torno de 50\%, é possível chegar-se à quantidade de bicarbonato de amônio produzida na forma de fertilizante, dividindo-se a quantidade de $\mathrm{CO}_{2}$ por 0,9, conforme indicado na revisão da literatura em Martin, 2002 e Bernardi, 2009. Na TAB. 28 apresentam-se esses dados.

TABELA 28 - Previsão de produção de $\mathrm{NH}_{4} \mathrm{HCO}_{3}$ através da captura de $\mathrm{CO}_{2}$ pela gaseificação e reforma de resíduos de biomassa, por região brasileira em dezembro de 2007.

\begin{tabular}{|c|c|c|c|}
\hline Região & Quantidade de $\mathrm{CO}_{2}(\mathrm{t})$ & & Quantidade de $\mathrm{NH}_{4} \mathrm{HCO}_{3}(\mathrm{t})$ \\
\hline $\mathrm{N}$ & 10.280 .932 & & 11.423 .257 \\
\hline $\mathrm{NE}$ & 48.309 .601 & & 53.677 .334 \\
\hline $\mathrm{CO}$ & 95.794 .817 & $: 0,9$ & 106.438 .685 \\
\hline SE & 154.603 .552 & & 171.781 .724 \\
\hline S & 121.450 .443 & & 134.944 .936 \\
\hline Total & 430.439 .348 & & 478.265 .942 \\
\hline
\end{tabular}




\section{7. Valoração do fertilizante produzido.}

Para a obtenção desses dados, foram usados como parâmetros os valores cotados pelo mercado internacional, proporcionais à disponibilidade de nitrogênio em cada produto, a saber, no caso do bicarbonato de amônio, em torno de 18,5\% e, no caso da uréia, usada como base de cálculo, em torno de $44,91 \%$ de nitrogênio livre ${ }^{315}$.

Pelo fato do bicarbonato de amônio ainda ser um fertilizante pouco usado para a adubação em larga escala (segundo Lee (2003), apenas na China seu uso é feito há mais tempo), fez-se sua valoração em função da quantidade de nitrogênio disponível para as necessidades nutricionais do vegetal.

A cotação do mercado internacional para a uréia, em dezembro de 2008, era de US\$223,00/t ${ }^{315}$.

Aplicando-se a proporcionalidade de nitrogênio livre ao bicarbonato de amônio, obtêm-se um preço estimado de US $\$ 91,76 /$ t.

$\mathrm{Na}$ TAB. 29 apresenta-se o exposto até o momento.

TABELA 29 - Valoração estimada do fertilizante $\mathrm{NH}_{4} \mathrm{HCO}_{3}$ na cotação de mercado em dezembro de 2008.

\begin{tabular}{ccc}
\hline $\begin{array}{c}\text { Quantidade de } \\
\mathrm{NH}_{4} \mathrm{HCO}_{3}(\mathrm{t})\end{array}$ & $\begin{array}{c}\text { Valor estimado } \\
\text { para a tonelada do } \\
\mathrm{NH}_{4} \mathrm{HCO}_{3}\end{array}$ & Total \\
\hline $\mathbf{4 7 8 . 2 6 5 . 9 4 2}$ & US\$91,76 & US\$ 43.885.682.287,36 \\
& $(\mathrm{R} \$ 76.622 .985 .606,56)$ \\
\hline
\end{tabular}

Portanto, pode-se inferir que o valor financeiro que é obtido com a quantidade total de bicarbonato de amônio, indicada na TAB. 29, é de aproximadamente US $\$ 43,8$ bilhões (ou R $\$ 76,6$ bilhões), considerando-se as cotações das respectivas moedas, em dezembro de 2008. 


\section{8. Valoração das RCE's}

$\mathrm{Na} T A B .30$ está indicado quanto de $\mathrm{CO}_{2}$ pode ser capturado na forma de $\mathrm{NH}_{4} \mathrm{HCO}_{3}$ e o valor que este $\mathrm{CO}_{2}$ atinge no mercado de créditos de carbono, segundo as cotações das RCEs de março de $2009^{313,316}$.

TABELA 30 - Valoração do $\mathrm{CO}_{2}$ capturado/ Março de 2009

\begin{tabular}{ccc}
\hline $\begin{array}{c}\mathrm{CO}_{2} \text { capturado } \\
\text { por gaseificação } \\
\text { na forma de } \\
\mathrm{NH}_{4} \mathrm{HCO}_{3} \text { em } \\
\text { t/ano }\end{array}$ & $\begin{array}{c}\text { Valor da t de } \\
\mathrm{CO}_{2} \text { não } \\
\text { emitida em US } \$\end{array}$ & $\begin{array}{c}\text { Valor obtido na venda } \\
\text { de } \mathrm{RCEs} \\
\text { (US } \$ / \text { ano) }\end{array}$ \\
\hline $\mathbf{4 3 0 . 4 3 9 . 3 4 8}$ & 14,51 & $\mathrm{US} \$ 6.245 .674 .895$ \\
& & $(\mathrm{R} \$ 10.903 .028 .608,85)$ \\
\hline
\end{tabular}

Somando-se os valores obtidos nas TAB 29 e 30 estimamos os totais possíveis que se pode lucrar, com a captura de $\mathrm{CO}_{2}$ pela gaseificação e seu consequente sequestro na formação do fertilizante bicarbonato de amônio, com a venda das RCE's obtidas nessa captura.

Na TAB. 31 apresentam-se esses resultados.

TABELA 31 - Valores obtidos com a produção de fertilizante e a venda das RCE's resultantes do sequestro de carbono. 


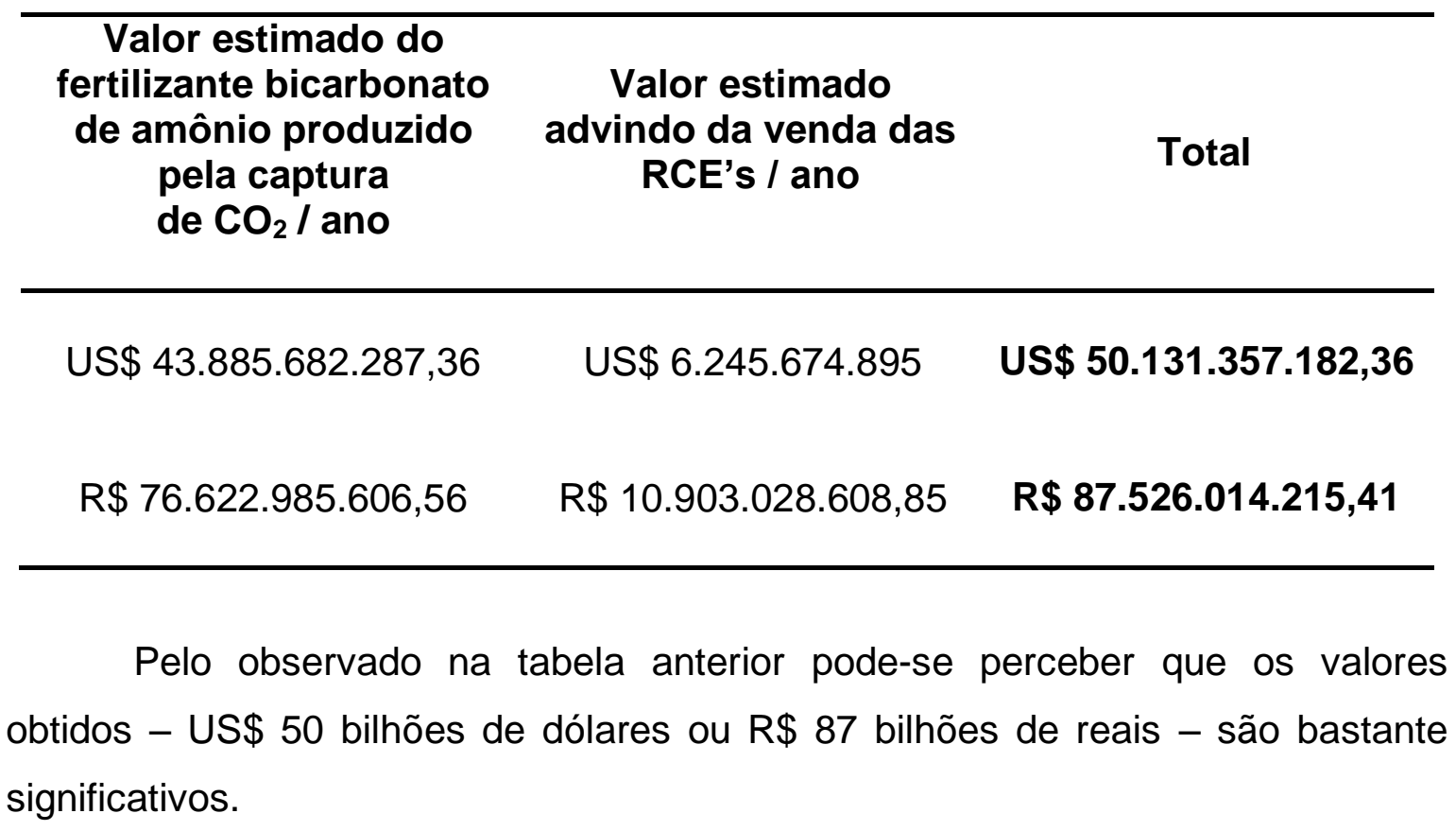




\section{CONCLUSÕES, PERSPECTIVAS E RECOMENDAÇÕES}

Se as grandes reduções nas emissões de gases com efeito de estufa são necessárias para o cumprimento das metas da UNFCCC de estabilização das emissões antropogênicas, então é preciso a combinação de medidas de mitigação para obter as necessárias e profundas reduções nessas emissões, dentre eles o gás carbônico.

Assim sendo, o ineditismo deste trabalho traz conclusões e perspectivas que permitem evidenciar sua imediata aplicabilidade no cenário nacional e mundial, visando permitir não somente a entrada de novas fontes de recursos financeiros, bem como a oportunidade concreta de contribuir com a estabilidade dos ecossistemas do planeta.

Aproximadamente metade de todas as emissões de $\mathrm{CO}_{2}$ é devido à atividade humana utilizadas para gerar energia. Uma variedade de processos industriais emite grandes quantidades de $\mathrm{CO}_{2}$, como refinarias de petróleo, fábricas de cimento e produção de ferro e aço. Estas emissões poderiam ser reduzidas substancialmente, envolvendo mudanças no processo básico, através da captura e armazenamento de $\mathrm{CO}_{2}$. Outras fontes de emissões, como os transportes e edifícios residenciais, não podem ser tratadas de maneira diferente apenas pelo fato de serem pequenas fontes emissores, pois são significativas em número.

Há muitas maneiras nas quais as emissões de $\mathrm{CO}_{2}$ podem ser reduzidas, como aumentar a eficiência das usinas ou mudar a partir do carvão para gás natural. No entanto, a maioria dos cenários sugere que estas medidas por si só não atingirão as reduções necessárias. A captura e armazenamento de $\mathrm{CO}_{2}$ provenientes da queima de combustíveis fósseis deve desempenhar um papel importante na resolução deste problema.

No curto prazo, o sistema de energia do mundo deve basear-se em fontes de energia não fósseis. Descarbonizar a utilização de combustíveis fósseis, por captura e armazenamento de $\mathrm{CO}_{2}$, ajudaria na transição para um futuro livre dessa preocupação.

O protocolo de Quioto expira em 2012, e já há o compromisso da ONU e de alguns governos para o delineamento de um novo acordo ou o que é mais 
provável, de uma emenda no Protocolo de Kyoto, que estabeleceria novas metas a serem cumpridas após 2012.

As discussões, iniciadas em fevereiro de 2007 com os chefes de estado do Canadá, França, Alemanha, Itália, Japão, Rússia, Reino Unido, Estados Unidos, Brasil, China, Índia, México e África do Sul concordaram em princípio sobre o esboço de um sucessor para o Protocolo de Kyoto, discutindo, em especial, a criação de um limite máximo para o comércio dos créditos de carbono, bem como a aplicação de metas de redução das emissões de $\mathrm{CO}_{2}$ aos países em desenvolvimento, propondo-se a delinear tal esboço até o término de 2009, em Copenhague.

De uma forma premente, a aceleração das mudanças climáticas pelas quais passa o nosso planeta, principalmente em função da queima de combustíveis fósseis para a produção de energia, vem fazendo com que a comunidade cientifica intensifique os estudos em soluções para a substituição dessa matriz energética não renovável.

Dentro do leque de opções de energias renováveis, a gaseificação da biomassa assume um lugar de destaque em um país como Brasil, cuja localização geográfica e a aptidão agrícola são nítidas.

No processo de gaseificação-sequestro sugerido neste trabalho, unemse três etapas: a implantação da gaseificação da biomassa, a captura do $\mathrm{CO}_{2}$ na forma do fertilizante bicarbonato de amônio e a geração de créditos de carbono para negociação de mercado, desse modo encontramos valores extremamente atraentes e passiveis de uso e aplicação, de forma imediata.

Dessa forma, sequestrar o $\mathrm{CO}_{2}$ nas camadas de solo e subsolo da terra, na forma do fertilizante bicarbonato de amônio trará vantagens, por exemplo, aos agricultores em termos de disponibilidade de nitrogênio para as suas culturas de maneira mais barata, já que pode ser produzido nacionalmente com matéria prima que, em parte, estaria disposta e sem aproveitamento no meio ambiente, causando um recrudescimento no efeito estufa. Além disso, ao seu sequestro agrega-se a diminuição da contaminação da água subterrânea pelo nitrato, usado em fertilizantes industriais.

As quantidades de bicarbonato de amônio a serem produzidas são significativas, em torno de 478 milhões de toneladas, e levariam a abrir um novo e 
promissor mercado para o Brasil, já que ao preço estimado de US $\$ 91,76$ geraria divisas na casa dos US $\$ 43,8$ bilhões (ou $R \$ 76,6$ bilhões) para o Brasil, por ano.

Outro aspecto do processo aqui sugerido é a possibilidade de geração de receita pela implantação de projetos de MDL e a consequente geração de Reduções de Emissão Certificadas (RCEs). Estas podem ser negociadas no mercado mundial, atraindo assim financiamentos, nacionais ou internacionais, visando à geração de energia renovável de baixo impacto ambiental e, dessa forma aproveitando o $\mathrm{CO}_{2}$, um gás energético, de maneira controlada contra 0 sistema de queima simples, processo largamente empregado no campo, sem controle, no Brasil e no mundo.

Dessa forma a geração de RCE's através da captura do $\mathrm{CO}_{2}$ demonstra o elevado potencial de aproveitamento desse recurso em nosso país, pela grande disponibilidade de biomassa passível de ser gaseificada.

Cabe ressaltar que esse item é de relevante importância para o meio ambiente e deve integrar o rol de ações que estão em harmonia com os ecossistemas terrestres.

Independentemente da origem dos fluxos de investimento, a implantação de um MDL irá alavancar um volume de recursos para o desenvolvimento sustentável muito maior do que apenas o valor dos RCE's permitiria esperar.

Nesta proposta de trabalho, o valor de US $\$ 50$ bilhões alavancaria uma série de benefícios, desde ambientais até sociais, com atividades de geração de energia.

Apesar de ser, ainda, um mercado que é regido pelas leis da oferta e procura e suscetível às crises financeiras mundiais, os valores que poderiam ser alcançados são substanciais e não podem ser desprezados em projetos que envolvem a liberação de $\mathrm{CO}_{2}$ em seus processos.

Com este estudo prova-se, principalmente, que um método simples e eficiente pode também trazer ganhos ambientais e, nesse sentido, os créditos de carbono em si, tornam-se parte importante do fundo para o financiamento de projetos e manutenção ou amortização dos projetos já implantados.

Há que se perceber que um financiamento dirigido explicitamente ao desenvolvimento sustentável pode ser suficiente para revolucionar a trajetória de crescimento de uma região ou de um país. 
Também é importante considerar que, em nossa sociedade o custo ambiental de projetos energéticos de grande impacto comumente utilizando combustíveis fósseis ainda não considera o devido custo ambiental embutido em seu preço.

Nosso país apresenta uma grande superfície, com regiões de difícil acesso, onde a geração distribuída com o aproveitamento da biomassa poderá vir a ser uma interessante alternativa para atender com eletricidade as comunidades isoladas melhorando as condições de vida relacionadas à energia elétrica.

Por tudo isso é de fundamental importância que estudos mais intensos visando o aprimoramento das tecnologias envolvidas e o aperfeiçoamento dos mecanismos de mercado, continuem sendo feitos, abrindo desta maneira, mais horizontes para um aproveitamento mais racional, tecnológico e ambientalmente saudável, principalmente no que tange a geração de energia.

Esse não é um fator que possa ser considerado de menor importância em toda a equação que envolve um projeto de energia renovável, já que as tecnologias disponíveis para elas implicam, até o momento, em maiores custos para implantação e geração, fazendo com que qualquer acréscimo de receita venha a aumentar a viabilidade de um projeto.

Esse potencial requer, ainda, um aprofundamento nas pesquisas para a acomodação de tecnologias trazidas de outros países e o aperfeiçoamento das aqui já desenvolvidas, além de um constante interesse dos órgãos governamentais no incentivo às entidades a ele relacionadas. 


\section{PROPOSTA DE TRABALHOS FUTUROS}

O presente estudo não tem a pretensão de encerrar a questão da relação entre os temas desenvolvidos, principalmente quanto ao desenvolvimento sustentável no Brasil.

Assim, para trabalhos futuros nessa temática, pode ser sugerido que sejam realizados estudos junto aos projetos implementados, identificando resultados, tanto em relação às reduções de emissões obtidas quanto sua contribuição ao desenvolvimento sustentável, permitindo com isto validar as conclusões obtidas frente às metodologias sugeridas.

Além disto, quando se observa a matriz energética brasileira, verifica-se que alguns aspectos ainda revelam pouca contribuição quanto aos projetos de MDL, citando-se, por exemplo, a melhoria em avanços tecnológicos, o maior uso de energias renováveis, uma visão mais ampla quanto ao aspecto ambiental, à capacidade de adaptação de comunidades e regiões, a dimensão social, entre outros.

Para melhor explicar este importante ponto da realidade realizou-se uma estimativa da previsão de captura de $\mathrm{CO}_{2}$ em usinas termoelétricas, abrindo, nesse sentido, espaço para perspectivas de trabalhos futuros.

Segundo dados coletados junto ao MME e ao BEN (2007), se fosse levada em consideração a capacidade disponível de geração elétrica a partir das usinas termoelétricas instaladas no Brasil, que é de $21.324 \mathrm{MW}{ }^{314}$, ou uma disponibilidade de geração de 186.798.240 MWh de energia, percebe-se que uma quantidade significativa de $\mathrm{CO}_{2}$ poderia ser capturada e aproveitada para a produção do fertilizante bicarbonato de amônio através da utilização do sistema gaseificação-sequestro desse gás, proposto neste trabalho.

Aplicando-se a mesma base de cálculo que foi utilizada para a gaseificação da biomassa, no item 6.7 deste trabalho "Valoração do fertilizante produzido", pode-se calcular quanto de $\mathrm{CO}_{2}$ seria capturado na forma do fertilizante bicarbonato de amônio e o valor que esta captura atingiria no mercado de créditos de carbono, segundo as cotações das RCE's de dezembro de $2008^{313,316}$.

Na TAB. 32 apresentam-se esses resultados. 
TABELA 32 - Previsão de produção de $\mathrm{NH}_{4} \mathrm{HCO}_{3}$ com a utilização do $\mathrm{CO}_{2}$ proveniente da queima das termoelétricas do sistema nacional em dezembro de $2008^{313,316,318}$.

\begin{tabular}{lcccc}
\hline Sistema & $\begin{array}{c}\mathrm{CO}_{2} \\
\text { emitido } \\
\mathbf{e m} \\
\mathbf{t} / \mathbf{M W h}\end{array}$ & $\begin{array}{c}\mathrm{CO}_{2} \\
\text { emitido } \\
\mathbf{e m} \\
\mathbf{t} / \mathbf{a n o}\end{array}$ & $\begin{array}{c}\text { Quantidade } \\
\text { de }\end{array}$ & $\begin{array}{c}\text { Valor obtido na venda } \\
\text { de RCEs } \\
\text { (US\$/ano) }\end{array}$ \\
\hline Termoelétrica & 0,5 & 93.399 .120 & 103.776 .800 & $\begin{array}{c}\mathrm{US} \$ 1.355 .221 .231,20 \\
(\mathrm{R} \$ 2.352 .664 .057,363)\end{array}$ \\
\hline
\end{tabular}

Com os valores estimados pode-se, portanto, recomendar um estudo com uma abordagem que analise esses pontos, bem como propor alternativas para sua integração à política climática mundial e nacional. 


\section{GLOSSÁRIO}

A

- Acordos de Marraqueche (Marrakech Accords) - Firmados durante a $7^{\mathrm{a}}$ Sessão da Conferência das Partes da Convenção-Quadro das Nações Unidas sobre Mudança do Clima - COP. Representam as decisões relativas à regulamentação do Protocolo de Kyoto, inclusive quanto aos de implementação adicional e, por conseguinte, do MDL.

- Adicionalidade (Additionality) - Critério fundamental para que uma determinada atividade de projeto seja elegível ao MDL. Consiste na redução de emissões de GEE ou no aumento de remoções de $\mathrm{CO}_{2}$ de forma adicional ao que ocorreria na ausência de tal atividade.

- Anexo A - Corresponde aos GEE e às categorias de setores e fontes que estão direta ou indiretamente relacionados com essas emissões. Exemplificando GEE tais como dióxido de carbono $\left(\mathrm{CO}_{2}\right)$, metano $\left(\mathrm{CH}_{4}\right)$, óxido nitroso $\left(\mathrm{N}_{2}\right)$, entre outros. $E$ exemplos de categorias de setores e fontes emissoras, tais como energia, queima de combustível, setor energético, indústrias de transformação e de construção, transporte.

- Anexo B - Neste Anexo ao Protocolo de Kyoto estão listadas as metas de redução de emissões de gases de efeito estufa, que são exclusivas às Partes Anexo I da CQNUMC. Existem 39 Partes Anexo B, que são as mesmas 41 listadas no Anexo I da Convenção com exceção da Turquia e de Belarus (Bielo-Rússia).

- Anexo C - Corresponde às decisões adotadas pela Conferência das Partes (COP), às questões metodológicas relacionadas ao Protocolo de Kyoto, à elaboração e implementação dos que entrarão em votação e/ou em vigor de acordo com a Convenção. 
- Anexo D - Corresponde aos relatórios das Conferências das Partes em sua terceira sessão onde foram definidos os totais das emissões de dióxido de carbono das Partes do Anexo 1 em 1990, para os fins do Artigo 25 do Protocolo de Kyoto.

- Aprovação pela Autoridade Nacional Designada (AND) - Consiste na aprovação dada pela AND a um país onde são implementadas as atividades de projeto do MDL no sentido de que tal atividade contribui para o desenvolvimento sustentável desse país.

- Atividades de Projeto (Project Activities) - Atividades integrantes de um empreendimento ou projeto candidato ao MDL que proporcionem redução da emissão de GEEE ou o aumento da remoção de $\mathrm{CO}_{2}$.

- Atividades de Projeto de Pequena Escala (Small Scale Project Activities) - São atividades de projeto de menor custo de transação.

- Atmosfera - Atmosfera é a camada gasosa que envolve o planeta. A atmosfera terrestre consiste de $77 \%$ de nitrogênio e $21 \%$ de oxigênio. $O$ resto é vapor d'água e outros gases.

- Atores (Stakeholders) - Os atores são público, incluindo os indivíduos, grupos e comunidades afetados ou com possibilidade de serem afetados pela atividade de projeto do MDL.

- Autoridade Nacional Designada - ADN (Designated National Authority - DNA) - Os governos dos países participantes de uma atividade de projeto do MDL devem designar junto à CQNUMC uma Autoridade Nacional para o MDL. Essa Autoridade Nacional Designada (AND) atesta que a participação dos países é voluntária e, no caso do país onde são implementadas as atividades de projeto, que ditas atividades contribuem para o desenvolvimento sustentável do país. 
B

- Biosfera - A Terra é composta por vários ecossistemas sejam eles aquáticos, terrestres ou até mesmo aéreos. A soma de todos estes ecossistemas é a biosfera. Portanto, a biosfera seria a parte na qual ocorre vida no planeta e na qual a vida tem poder de ação.

- BS 7750 - conjunto de normas e diretrizes de gestão ambiental envolvendo diferentes organizações e acompanhando o desenvolvimento ambiental, aspectos gerais, termos e definições básicas, sistemas de gerenciamento ambiental, política ambiental, planejamento, implementação e operação, verificação e ação corretiva e análise crítica de empresas em geral.

- BTU - é um acrônimo para British Thermal Unit (Unidade Térmica Britânica) - uma unidade de medida não-métrica e, não pertencente ao Sistema Internacional (SI), usada principalmente nos E.U.A. e no Reino Unido. É uma unidade de energia que tem as seguintes equivalências: 1 $\mathrm{BTU}=252,2$ calorias ou 1.055,05585 joules. A quantidade de 1 BTU é definida como aquela quantidade de energia para elevar a temperatura de uma massa de uma libra de água em um grau Fahrenheit. Para se derreter a mesma massa de gelo, é necessário 143 BTU.

C

- Camada de Ozônio - Camada da estratosfera formada pelo gás ozônio, que atua como barreira parcial à penetração da radiação ultravioleta incidente na superfície terrestre, protegendo-a, dos efeitos prejudiciais à saúde e ao meio ambiente, causados pelo excesso de tal radiação.

- Cenário de Referência (Business-as-usual Scenario) - Cenário que quantifica e qualifica as emissões de gases de efeito estufa na ausência da atividade de projeto do MDL.

- Certificação (Certification) - Parte de uma das etapas do Ciclo do Projeto. Consiste na garantia formal concedida por uma EOD de que uma 
determinada atividade de projeto atingiu um determinado nível de redução de emissões de gases de efeito estufa ou aumento de remoção de $\mathrm{CO}_{2}$ durante um determinado período de tempo específico.

- CGD - Centro de Desenvolvimento Global - É uma organização independente, sem fins lucrativos, cuja política de investigação é dedicada a reduzir a pobreza global e a desigualdade. Através de uma combinação de pesquisa e extensão estratégica, o Centro envolve ativamente os responsáveis políticos e o público para influenciar as políticas dos Estados Unidos, outros países ricos, e instituições como o Banco Mundial, o FMI e a Organização Mundial do Comércio para melhorar a economia e as perspectivas de desenvolvimento social nos países pobres. CGD foi recentemente classificado entre os melhores do mundo, 15이 lugar dentre vários milhares de organizações de pesquisa.

- Ciclo do projeto (Projeto Cycle) - Etapas às quais uma atividade de projeto do MDL deve necessariamente se submeter para que possa originar RCEs, a última etapa do Ciclo do Projeto.

- Clorofluorcarbonos - Também conhecidos por CFC's, são substâncias químicas artificiais, utilizadas principalmente em refrigeradores, condicionadores de ar e aerossóis, e constituem o mais poderoso gás que provocam a intensificação do efeito estufa.

- Comércio de Emissões - Um dos mecanismos do Protocolo de Kyoto. Prevê que as Partes Anexo I podem participar do comércio de emissões com outras Partes Anexo I, objetivando cumprir compromissos de limitação e redução de emissões assumidos. A unidade aplicável a este mecanismo é a Unidade de Quantidade Atribuída - UQA.

- Comissão Interministerial de Mudança Global do Clima- CIMGC Estabelecida por Decreto Presidencial em 7 de Julho de 1999, é a AND do Brasil. Avalia e aprova os projetos considerados elegíveis no âmbito do $\mathrm{MDL}$, bem como pode definir critérios adicionais de elegibilidade àqueles considerados na regulamentação do Protocolo de Kyoto. 
- Conferência das Partes (Conference of the Parties - COP) - Órgão máximo da CQNUMC, composto por todos os países que ratificaram e é responsável pela sua implementação. A COP se reúne anualmente.

- Conferência das Partes na qualidade de Reunião das Partes do Protocolo (Conference of the Parties - COP/Meeting of the Parties MOP) - Órgão supremo do Protocolo. Parte das decisões tomadas pelo Comitê Executivo do MDL deverá ser referenda pelo COP/MOP.

- Conselho Executivo do MDL (CDM Executive Board): - Supervisiona o funcionamento do MDL. Entre as suas responsabilidades, destacam-se: (i) o credenciamento das Entidades Operacionais Designadas; (ii) a validação e registro das atividades de projetos do MDL; (iii) a emissão das RCEs; (iv) o desenvolvimento e operação do Registro do MDL e (v) o estabelecimento e aperfeiçoamento de metodologias para linha de base, monitoramento e fugas.

- Convenção-Quadro das Nações Unidas sobre Mudança do ClimaCQNUMC (United Nations Framework Convetion on Climate Change UNFCCC) - Convenção negociada sob a égide das Nações Unidas, adotada durante a Rio-92 e com objetivo de estabilização dos níveis de concentração de GEE na atmosfera num nível que impeça uma interferência antrópica perigosa no sistema climático. O Protocolo de Kyoto é um instrumento jurídico complementar e vinculado à CQNUMC.

- COP/MOP - (Conference of the Parties serving as the meeting of the Parties to the Kyoto Protocol) - a Conferência das Partes como Reunião das Partes do Protocolo de Kyoto, estabelecida pelo Artigo 13.1, é o órgão supremo do Protocolo, tendo por responsabilidade promover sua implementação efetiva

- Custos de Transação (Transaction Costs) - No caso especifico do MDL,são os custos relacionados ao Ciclo do Projeto e à comercialização das RCEs. 
D

- DDF - Development Dividend Framework - A metodologia, chamada Development Dividend Framework (DDF), utiliza um conjunto de critérios de avaliação determinados para efetuar a quantificação dos projetos propostos ao $\mathrm{MDL}$ quanto sua contribuição ao desenvolvimento sustentável, permitindo sua comparação relativa.

- Desmatamento - Processo de alteração da cobertura vegetal movido pela espécie humana em que a vegetação resultante armazena menos carbono do que a original (incluindo o solo sobre o qual ela se encontra).

- Dióxido de Carbono $\left(\mathrm{CO}_{2}\right)$ - Representado pela fórmula $\mathrm{CO}_{2}$, é um gás naturalmente presente na atmosfera terrestre em quantidades muito pequenas (apenas cerca de $0,03 \%$ do volume da atmosfera é constituído por este gás). É um importante fator na fotossíntese, pois fornece o carbono que será usado para a fabricação de moléculas que armazenam energia na forma de ligações químicas. Trata-se do mais importante gás que provoca o efeito estufa, depois do vapor d'água.

- Documento de Concepção do Projeto DCP (Projeto Design Document - PDD) - A elaboração do DCP é a primeira etapa do ciclo do projeto. Todas as informações necessárias para as etapas posteriores deverão estar contempladas no DCP.

$\mathbf{E}$

- Emissão de RCEs. (Emissions of CERs) - Etapa final do Ciclo do Projeto, quando o Conselho Executivo tem certeza de que, cumpridas todas as etapas, as reduções de emissões de gases de efeito estufa decorrentes das atividades de projetos são reais, mensuráveis e de longo prazo e, portanto podem dar origem a RCEs. 
- Entidade Operacional Designada - EOD (Designated Operational Entity - DOE) - Entidade credenciada pelo Conselho Executivo do MDL com a finalidade de: (i) validar as atividades de projeto propostas ao MDL e (ii) verificar e certificar as reduções das emissões de gases de efeito estufa e/ou remoção de $\mathrm{CO}_{2}$. A Entidade Operacional depois de credenciada pelo Conselho Executivo deverá, ainda, ser designada pela COP/MOP, que dessa forma ratificará ou não o credenciamento feito pelo Conselho Executivo.

- Fotossíntese - A fotossíntese é uma função que apenas os vegetais são capazes de realizar. É através dela que as plantas produzem compostos orgânicos ricos em energia (glicose) e liberam oxigênio. A fotossíntese ocorre quando a água e o gás carbônico, na presença da luz, dão origem à glicose, nas partes verdes dos vegetais. A folha é a parte do vegetal em que mais se realiza a fotossíntese. Além de ser rica em clorofila, sua posição na planta, geralmente exposta à luz, e sua forma laminar permitem que a energia do sol seja absorvida com maior eficiência.

- Fuga (Leakage) - Corresponde ao aumento de emissões de gases de efeito estufa que ocorre fora do limite da atividade de projeto do MDL que, ao mesmo tempo, seja mensurável e atribuível a essa atividade de projeto. A fuga é deduzida da quantidade total de RCEs obtidas pela atividade de projeto do MDL. Dessa forma, são considerados todos os possíveis impactos negativos em termos de emissão de gases de efeito estufa da atividade de projeto do MDL

G

- Gases de Efeito Estufa - GEE - (Greenhouse Gases - GHG) - São os gases listados no Anexo A do Protocolo de Kyoto, quais sejam: (i) dióxido de carbono $\left(\mathrm{CO}_{2}\right)$; (ii) metano $\left(\mathrm{CH}_{4}\right)$; (iii) óxido nitroso $\left(\mathrm{N}_{2} \mathrm{O}\right)$; (iv) hexafluoreto de enxofre $\left(\mathrm{SF}_{6}\right)$; e $(\mathrm{v})$ famílias de gases hidrofluorcarbonos (HFCs) e perfluorcarbonos (PFCs), cujas reduções podem gerar RCEs, 
UQAs e UREs no âmbito do Protocolo de Kyoto e, no caso de $\mathrm{CO}_{2}$, cuja remoção pode gerar URMs.

- Implementação Conjunta (Joint Implementation) - Outro dos mecanismos do Protocolo de Kyoto, pelo qual uma Parte Anexo I pode transferir para ou adquirir de qualquer outra Partes Anexo I unidades de redução de emissões - UREs, a fim de cumprir seus compromissos quantificados de limitação e redução de emissões de gases de efeito estufa.

- ISO - International Organization for Standardization ou Organização Internacional de Normalização. Fundada em 23 de Fevereiro de 1947, em Genebra, na Suíça, a ISO aprova normas internacionais em todos os campos técnicos, exceto na eletricidade e eletrônica, cuja responsabilidade é da International Electrotechnical Commission (IEC), fundada em 1906.

$\mathbf{L}$

- Limites do Projeto (Project Boundaries) - O limite da atividade de projeto deve abranger todas as emissões de gases de efeito estufa sob controle dos participantes da atividade de projeto que sejam significativas e atribuíveis, de forma razoável, a tal atividade. Essas emissões devem ser contabilizadas na Linha de base. A metodologia para definir os limites do projeto faz parte do DCP. As emissões significativas e atribuíveis, de forma razoável, às atividades do projeto, mas que estejam fora do limite do projeto, são classificados como fuga.

- Linha de Base (Baseline) - No âmbito do MDL, a Linha de base de uma atividade de projeto do MDL é o cenário que representa, de forma razoável, as emissões antrópicas de gases de efeito estufa por fontes que ocorreriam na ausência da atividade de projeto proposta, incluindo as emissões de todos os gases, setores e categorias de fontes listados no Anexo A do Protocolo de Kyoto que ocorram dentro do limite do projeto. Serve de base tanto para verificação da adicionalidade quanto para a 
quantificação das RCEs da atividade de projeto MDL. As RCEs serão calculadas justamente pela diferença entre emissões da linha de base e emissões verificadas em decorrência das atividades de projeto do MDL, incluindo as fugas. A linha de base é qualificada e quantificada com base em um Cenário de Referência.

M

- Mecanismo de Desenvolvimento Limpo- MDL (Clean Development Mechanism - CDM) - Um dos três mecanismos de implementação adicional. O MDL foi definido no Artigo 12 do Protocolo de Kyoto e regulamentado pelos Acordos de Marrakech. Dispõe sobre atividades de projetos de redução de emissão gases de efeito estufa ou aumento de remoção de CO2, implementadas em Partes Não Anexo I, que irão gerar Reduções Certificadas de Emissões (RCEs).

- Mecanismos de Implementação Adicional - Conferem um certo grau de flexibilidade e ajudam as Partes Anexo I no cumprimento de suas metas de redução de gases de efeito estufa. São três: (i) Implementação Conjunta, definida no Artigo 6 do Protocolo de Kyoto, (ii) Mecanismo de Desenvolvimento limpo, definido no Artigo 12, e (iii) Comércio de Emissões, definido no Artigo 17.

- Metano $\left(\mathrm{CH}_{4}\right)$ - Também conhecido como "gás dos pântanos", é formado pela decomposição de compostos orgânicos na ausência de oxigênio por determinadas bactérias, seja em pântanos, seja no estômago do gado, seja no de outros ruminantes. Fontes adicionais, induzidas pela espécie humana, são a queima de biomassa vegetal, vazamentos de dutos de gás natural, plantio de arroz em áreas alagadas e a mineração de certo tipo de carvão mineral. Boa parte do metano desaparece em reações químicas na própria atmosfera e uma fração pequena é absorvida por microorganismos existentes no solo. O metano contribuiu com $15 \%$ do efeito estufa.

- Monitoramento (Monitoring) - Quarta etapa do Ciclo do Projeto. Consiste no processo de coleta e armazenamento de todos os dados necessários 
para o cálculo da redução das emissões de gases de efeito estufa ou o aumento da remoção de $\mathrm{CO}_{2}$, de acordo com a metodologia de linha de base da atividade de projeto. O Plano de Monitoramento deve integrar $\mathrm{O}$ DCP e o processo de monitoramento será realizado pelos participantes da atividade de projeto.

0

- Ozônio $\left(\mathrm{O}_{3}\right)$ - Gás formado quando hidrocarbonetos reagem com óxidos de nitrogênio na presença de luz solar. É um dos poluentes mais graves da troposfera.

- OCDE - Organização para a Cooperação e Desenvolvimento Econômico. É uma organização internacional de 30 países que aceitam os princípios da democracia representativa e de livre mercado. Destes, México, Polônia e Turquia (marcados com*) são descritos como economias média/alta pelo Banco Mundial, porém a maioria de seus membros são economias de alta renda, com IDH alto e são considerados como países desenvolvidos. A sede da organização fica em Paris. Os países da OCDE são: Austrália, Áustria, Bélgica, Canadá, RepúblicaTcheca, Dinamarca, Finlândia, França, Alemanha, Grécia, Islândia, Hungria, Irlanda, Itália, Japão, Coréia do Sul, Luxembrugo, Holanda, Noruega, Portugal, Espanha, Suécia, Reino Unido, Estados Unidos da América, Nova Zelândia, Eslováquia, Polônia*, Suíça, México*, Turquia* e há um observador Taiwan.

Além disso, a União Européia, através da Comissão das Comunidades Européias, participa nos trabalhos da OECD, ao lado dos EstadosMembros da EU.

- Painel Intergovernamental sobre Mudança Climática (Intergovernmental Panel on Climate Change, IPCC) - Painel constituído por cientista de diversos países e áreas de conhecimento, com o objetivo de dar suporte cientifico e interagir com a CQNUMC. È responsável pela 
divulgação do cálculo do Potencial de Aquecimento Global (Global Warming Potential - GWP) e pelas revisões metodológicas deste cálculo.

- País onde são implementadas as atividades de Projeto do MDL - Parte Não Anexo I onde são implementadas as atividades de projeto no âmbito do MDL.

- Partes - Podem ser países isoladamente ou blocos econômicos, como por exemplo, a União Européia.

- Partes Anexo I (ou Anexo I) da CQNUMC - é integrado pelas Partes signatárias da Convenção pertencentes em 1990 à OCDE e pelos países industrializados da antiga União Soviética e do Leste Europeu. A divisão entre Partes Anexo I e Partes Não Anexo I tem como objetivo separar as partes segundo a responsabilidade pelo aumento da concentração atmosférica de gases de efeito estufa. As Partes Anexo I possuem metas de limitação ou redução de emissões.

- Partes Anexo II - são os países ricos listados no Anexo II da Convenção tem especial obrigação de ajudar com recursos financeiros e tecnológicos os países em desenvolvimento. Este grupo inclui os 24 primeiros membros originais da OECD e mais os da União Européia, sem os países em processo de transição para uma economia de mercado.

- Partes Não Anexo I - As Partes Não Anexo I são todas as Partes da CQNUMC não listadas no Anexo $\mathrm{I}$, entre as quais o Brasil, que não possuem metas quantificadas de redução de emissões.

- Partes Anexo B - No Anexo B do Protocolo de Kyoto estão definidas as metas de redução quantificada de emissões de gases de efeito estufa. Todas as Partes do Anexo I, à exceção da Turquia e da Belarus, estão listadas também no Anexo B. No âmbito do MDL, apenas Partes que aparecem listadas no Anexo $B$ e que tenham ratificado o Protocolo de Kyoto poderão utilizar RCEs como forma de cumprimento parcial de suas metas de redução de emissão de gases de efeito estufa. 
- Participantes do Projeto (Project Participants) - Para efeitos do MDL são aqueles envolvidos em uma atividade de projeto, podem ser Partes Anexo I, Partes Não Anexo I ou entidades públicas e privadas dessas Partes, desde que por elas devidamente autorizadas.

- Período de Obtenção de Créditos - Período em que as reduções de emissões de GEE decorrentes de atividades de projeto do MDL podem ser contabilizados para efeito de cálculo das RCEs. As reduções de emissões só poderão ser contabilizadas para efeito de cálculo das RCEs após o registro da atividade de projeto no Conselho Executivo do MDL.

- Plano de Monitoramento (Monitoring Plan) - Ainda que o processo de monitoramento faça parte da terceira etapa do Ciclo do Projeto, o Plano de Monitoramento, que define a metodologia para o processo, deve ser definido na primeira etapa, já que é parte integrante do DCP.

- Potencial de Aquecimento Global (Global Warming Potential, GWP) Índice divulgado pelo IPCC. Usado na uniformização das quantidades dos diversos gases de efeito em termos de dióxido de carbono equivalente, possibilitando que a reduções de diferentes gases sejam somadas. O GWP, que deve ser atualizado para o Primeiro Período de Compromisso (2008-2012), é o publicado no Segundo Relatório de Avaliação do IPCC.

- Primeiro Período de Compromisso (First Commitment Period) - O primeiro período de compromisso refere-se ao período compreendido entre 2008-2012.

- Protocolo de Kyoto - Instrumento jurídico internacional complementar e vinculado à Convenção-Quadro das Nações Unidas sobre Mudança do Clima, que traz elementos adicionais à Convenção. Entre as principais inovações estabelecidas pelo Protocolo, destacam-se os compromissos de limitação ou redução quantificada de emissões de gases de efeito estufa, definidos em seu Anexo B, bem como os mecanismos de implementação adicional, dentre os quais o MDL. 
$\mathbf{R}$

- Reduções Certificadas de Emissões - RCEs - Representam as reduções de emissões de gases de efeito estufa decorrentes de atividades de projetos elegíveis para o MDL e que tenham passado por todo o Ciclo de Projeto do MDL (validação/registro, monitoramento e verificação/certificação), que culmina justamente com a emissão das RCEs. As RCEs são expressas em toneladas métricas de $\mathrm{CO}_{2}$ equivalentes. As RCEs podem ser utilizadas por Partes Anexo I como cumprimento parcial de suas metas de redução de emissão de GEE.

- Reflorestamento / Florestamento (Reforestation / Aforestation) Reflorestamento conversão induzida pelo homem, de terra não florestada em terra floresta por plantio, semeadura e/ou a promoção de fontes naturais de sementes, em área que foi floresta, mas convertida em terra não floresta. Para o primeiro período de compromisso, atividades de reflorestamento são limitadas ao reflorestamento de terras que não possuíam florestas em 31/12/1989. Florestamento é a conversão induzida, diretamente pelo homem, de terra que não foi floresta por ao menos 50 anos, em terra floresta por plantio, semeadura e/ou a promoção de fontes naturais de sementes. No âmbito do MDL, as definições e modalidades de reflorestamento e de florestamento para o primeiro período de compromisso serão desenvolvidas considerando as questões de não permanência, adicionalidade, fuga, incertezas e impactos socioeconômicos e ambientais, inclusive, neste caso, os impactos sobre a biodiversidade e os ecossistemas naturais.

- Registro (Registry) - Parte da terceira etapa do Ciclo do projeto (Validação/Registro). Aceitação formal, pelo Conselho Executivo, de um projeto validado como atividade de projeto do MDL. Ele é pré-requisito para a verificação, certificação e emissão das RCEs relativas a uma atividade de projeto. Não confundir com "Registro do MDL" 
- Registro do MDL (CDM Registry) - Estabelecido e supervisionado pelo Conselho Executivo do MDL assegurarando a contabilização acurada da emissão, posse, transferência e aquisição de RCEs. O registro do MDL deverá conter dados eletrônica padronizados pertinentes à emissão, posse, transferência e aquisição de RCEs. Não confundir com o registro de projeto do MDL, uma das etapas do Ciclo do Projeto.

S

- Segundo Período de Compromisso (Second Commitment Period) Definido entre 2013 e 2017. As COP/MOP devem dar início à consideração de tais compromissos pelo menos sete anos antes do término do primeiro período de compromisso, ou seja, até 2005. RCEs, UREs e UQAs podem sertransferidas do primeiro para o segundo período de compromisso.

U

- Unidade de Redução de Emissão (Emission Reduction Unit - ERU) - É aplicada no âmbito do artigo 6 do Protocolo de Kyoto, que trata da Implementação Conjunta. Essa unidade é expressa em toneladas métricas de dióxido de carbono equivalente, sendo uma unidade igual a uma tonelada de gases de efeito estufa. A transformação para dióxido de carbono equivalente deve ser feita com base no Potencial de Aquecimento Global. As UREs podem ser utilizadas por Partes Anexo I como forma de cumprimento parcial de suas metas de redução de emissão de gases de efeito estufa ou transferidas parcialmente para o segundo período de compromisso.

- Unidades de Remoção URM (Removal Unit - RMU) - Representa remoções de gases de efeito estufa por sumidouros. As URMs são expressas em toneladas métricas de dióxido de carbono equivalente, sendo uma unidade igual a uma tonelada de gases de efeito estufa. A transformação para dióxido de carbono equivalente deve ser feita com base no Potencial de Aquecimento Global. As URMS podem ser utilizadas 
por Partes Anexo I como forma de cumprimento parcial de suas metas de redução de emissão de gases de efeito estufa em relação ao Artigo 3.

V

- Validação (Validation) - Parte da segunda etapa do Ciclo do Projeto (Validação/Registro). É o processo de avaliação independente de uma atividade de projeto por uma EOD, no tocante aos requisitos do MDL, com base no DCP.

- Verificação (Verification) - Parte da quinta etapa do Ciclo do Projeto (Verificação e Certificação). É o processo de auditoria periódica e independente realizado por uma EOD e destinada à revisão dos cálculos acerca da redução de emissões de gases de efeito estufa enviadas ao Conselho Executivo, por meio do DCP. Esse processo visa verificar, expost, se a redução de emissões efetivamente ocorreram na magnitude prevista ex-antes no DCP, e prevê ajustes em casos de diferenças. Apenas as atividades de projetos do MDL validadas e registradas são verificadas e certificadas. 


\section{REFERÊNCIAS BIBLIOGRÁFICAS}

1. GLOBAL WARMING POTENTIAL. The Complete Briefing of John Houghton. Cambridge: Cambridge University Press. 3. Ed. GWP, 2004.

2. BURROUGHS, W. J. Environmental Analysis and Problem Solving: A Multidisciplinary Approach. Cambridge: Cambridge University Press, 2002.

3. STRUCTURAL ADJUSTMENT PROGRAMME. Climate Change 1995: Economic and Social Dimensions of Climate Change - Contribution of Working Group III to the Second Assessment of the IPCC. Cambridge, UK: Cambridge University Press. SAP-WGIII, 1995.

4. ENERGY INFORMATION ADMINISTRATION. History: International Energy Annual 2006. (June-Dec. 2008). Projections: EIA, World Energy Projections Plus 2009. ElA. Disponivel em: $<$ http://www.eia.doe.gov/iea $>$. Acesso em: 02 ago. 2009.

5. ENERGY INFORMATION ADMINISTRATION. History: Office of Energy Markets and End Use, International Statistics Database and International Energy Annual 1999. (January 2001). Projections: EIA, World Energy Projection System (2001). EIA. Disponivel em: $<$ http://www.eia.doe.gov/iea>. Acesso em: 02 ago. 2009.

6. INTERGOVERNMENTAL PANEL ON CLIMATE CHANGE. Good Practice Guidance and Uncertainty Management in National Greenhouse Gas Inventories. IPCC, 2007.

7. PENNER, J. E. Aviation and the Global Atmosphere. Cambridge University Press. Cambridge, U.K. Databases to IPCC, 1999.

8. INTERGOVERNMENTAL PANEL ON CLIMATE CHANGE. Revised 2006 IPCC Guidelines for National Greenhouse Gas Inventories. Paris: United Nations Environment Programme, Organization for Economic CoOperation and Development, International Energy Agency. IPCC/UNEP/OECD/IEA, 1997.

9. HOFMANN, D. J.; BUTLER, J.H.; CONWAY,T.J.; DLUGOKENCKY, J. W.; ELKINS, K. M.; MONTZKA, S.A.; SCHNELL, R.C.; TANS, P. (2006b): Tracking climate forcing: The Annual Greenhouse Gas Index, EOS, Transactions, American Geophysical. Union, 87, Nov.16, 2006, 509-511. 
10. SANA, H. S. P. Aterros Sanitários e o Mercado de Créditos de Carbono: Análise de Viabilidade Econômica para Empreendimentos Sustentáveis em Municípios no Interior de São Paulo. São Paulo: IBMEC, 2006.

11. MRT. MINISTÉRIO DAS RELAÇÕES EXTERIORES. CQNUMC, Convenção Quadro das Nações Unidas Sobre Mudança do Clima. Tradução conjunta, MCT, MRT. Rio de Janeiro: FGV, 2002.

12. ENVIRONMENTAL PROTECTION AGENCY. Inventory of U.S. greenhouse gas emissions and sinks: 1990-2007. U. S. - Washington, DC 20460. April 2009. Disponível em:

$<$ http://www.epa.gov/climatechange/emissions/downloads09/InventoryUSG hG1990-2007.pdf>. Acesso em: 17 jun. 2009.

13. METZ, B.; DAVIDSON, O. R.; BOSCH, P. R.; DAVE, R.; MEYER, L.A. Climate Change 2007: Mitigation of Climate Change. Contribution of Working Group III to the Fourth Assessment Report of the Intergovernmental Panel on Climate Change, 2007 (IPCC). New York: Cambridge University Press.

14. BEIL, S. Evolution and design of an emissions trading market of greenhouse gases. Paper presented at the 2nd Annual Emissions Trading Forum. 30-31. Aug. 1999. Disponível em : $<$ http://www.aetf.net.au/ContentStore/ReferencePapers/Reference11.htm> Acesso em: 15 fev. 2007.

15. MIGUEZ, J. M. O Brasil e o Protocolo de Kyoto. Centro Nacional de Referência em Biomassa (CENBIO) Notícias, v. 3, n. 8, p. 3, 2000.

16. CONVENÇÃO QUADRO DAS NAÇÕES UNIDAS SOBRE MUDANÇA DE CLIMA. Protocolo de Kyoto e a Convenção sobre Mudança do Clima, 1997. MCT Disponível em:

$<$ http://www.mct.gov.br/clima/quioto/protocolo.htm $>$. Acesso em: 10 out. 2007.

17. UNITED NATIONS FRAMEWORK CONVENTION ON CLIMATE CHANGE. Request Inssuance of CER. UNFCCC. Disponível em: $<$ http://cdm.unfccc.int/Projects/pac/ar howto/Register/lssuance $>$. Acesso em: 27 jul. 2005.

18. CHRISTIANSON, G E. Grenhouse: the 200-year story of Global Warming. New York: Walker Publishing Company, 1999. 
19. MCT. MINISTÉRIO DA CIÊNCIA E TECNOLOGIA. Convenção Quadro Sobre Mudança do Clima. Guia de Orientação. Disponível em: $<$ http://www.mct.gov.br/clima/quioto/introduc.htm>. Acesso em: 17 set. 2005.

20. UNITED NATIONS STATISTICS DIVISION - ENVIRONMENTAL INDICATORS. Greenhouse Gas Emissions Disponível em: $<$ http://unstats.un.org/unsd/environment/air_co2_emissions.htm >. Acesso em: 25 nov. 2009.

21. SOUZA, N. M. S. Potencial de energia primária de resíduos vegetais no Paraná. 4ํㅡㄹ Encontro de Energia no Meio Rural, Out. 29-31, 2002. Campinas, São Paulo, S.P.

22. BRAZIL/U.S. ASPEN GLOBAL FORUM. Task force on early start projects for carbon emission reductions. São Paulo: Amcham, 2000. 39p.

23. MOUTINHO, P.; BUENO, M. O. O inventário brasileiro de emissões e o desmatamento na Amazônia. Clima em Revista, v. 2, n. 3, p. 1, 2002.

24. BODEN, T.A.; MARLAND, G.; ANDES, R.J. Global, Regional, and National Fossil-Fuel $\mathrm{CO}_{2}$ Emissions. Carbon Dioxide Information Analysis Center, Oak Ridge National Laboratory, U.S. Department of Energy, Oak Ridge, Tenn., U.S.A. DOI 10.3334/CDIAC/00001, 2009.

25. UNITED NATIONS FRAMEWORK CONVENTION ON CLIMATE CHANGE. UNFCCC. Convenção Sobre Mudança do Clima. Versão traduzida pelo MCT, Brasília. Disponível em:

$<$ http://www.mct.gov.br/clima/convencao/default.html>. Acesso em: 01 nov. 2005.

26. LIMA, M.A. Emissão de gases de efeito estufa provenientes da queima de resíduos agrícolas do Brasil. Jaguariúna. Embrapa, 1999.

27. PEREIRA, A. S. O Mecanismo de Desenvolvimento Limpo, Ministério de Minas e Energia, Secretaria Política para o Desenvolvimento Sustentável. MME, SPDS, 2006.

28. KIRCHHOFF, V. W. U. Queimadas no Brasil e no mundo e o efeito estufa. São Paulo: Contexto, 2002. 
29. ASSEMBLÉIA LEGISLATIVA DO ESTADO DE SÃO PAULO - Secretaria Geral Parlamentar - Departamento de Documentação e Informação Ementa sobre eliminação gradativa da queima da palha da cana-deaçúcar. Lei no 11.241, de 19/09/2002. Disponível em:

$<$ http://www.al.sp.gov.br/legislacao/norma.do?id=217> Acesso em: 16 abr. 2004.

30. SARIEGO, J. C. Educação ambiental: as ameaças ao planeta azul. 1. ed. São Paulo: Scipione, 2004.

31. HALL. D. O.; RAO, K. K. Photosyntesis. 6. ed. Cambridge: Cambridge University Press, 1999. 214 p.

32. A. PELLEGRINI, L.; OLIVEIRA, JR.S. Energy Analysis of Sugarcane Bagasse Gaseification. Energy. v. 32.p. 314, 2007a .

33. BANCO NACIONAL DE DESENVOLVIMENTO ECONÔMICO E SOCIAL. Efeito Estufa e a Convenção sobre Mudança do Clima. Rio de Janeiro: BNDES: MCT. Departamento de Relações Institucionais, 2005, 38 p.

34. MCCATHY, J. J.; CANZIANI, O. F.; LEARY, N. A.; DOKKEN, D. J.; WHITE, K. S. Climate Change 2004: impacts, adaptation and vulnerability. IPCC. Cambridge: Cambridge University, 2004, 1032 p.

35. KAPPEL, R.; SRAUB, P.; GRUTTER, J. M. Simulation the market for the greenhouse gas emission reductions. Heldswil: Grutter Consulting, 2004. 22p.

36. BRUNDTLAND, G. H. Nosso futuro comum: Comissão Mundial sobre Meio Ambiente e Desenvolvimento (CMMAD). 2. ed. Rio de Janeiro: FGV, 1991.

37. UNITED NATIONS FRAMEWORK CONVENTION ON CLIMATE UNFCCC. Caring for Climate: A guide to the Climate Change Convention and the Kyoto Protocol. Bonn, Germany: Climate Change Secretariat. 2005.

38. OLIVEIRA, P. A. V.; HIGARASHI, M. M.; NUNES, M. L. A. Efeito estufa: emissão de gases, na suinocultura, que provocam o efeito estufa. Suinocultura Industrial, São Paulo, v. 25, n. 7, p.16-20, 2003. 
39. ROCHA, Marcelo T. Aquecimento global e o mercado de carbono: uma aplicação do modelo CERT. 2003. Tese (Doutorado em Economia Aplicada) - Escola Superior de Agricultura Luiz de Queiroz, Universidade de São Paulo. Centro de Estudos Avançados em Economia Aplicada, CEPEA - ESALQ/USP. Piracicaba, São Paulo.

40. FALEIROS, G. Descoberta do Efeito Estufa faz $\mathbf{1 5 0}$ anos. Folha de São Paulo, São Paulo, 21 jun. 2009. Ciência e Saúde. Disponível em: $<$ http://www1.folha.uol.com.br/folha/ciencia/ult306u584162.shtml $>$ Acesso em: 30 ago. 2009.

41. BEIL, S. Evolution and design of an emissions trading market of greenhouse gases. $2^{\circ}$ Annual Emissions Trading Forum, 1999.

42. PLANO NACIONAL DE AGROENENERGIA 2006-2011 - Ministério da Agricultura, Pecuária e Abastecimento, Secretaria de Produção e Agroenergia. 2. ed. rev. - Brasília, DF : Embrapa Informação Tecnológica, 2006. $110 \mathrm{p}$.

43. KEELING, C. D.; BACASTOW, R. B.; WHORF, T. P. Measurements of the Concentration of Carbon Dioxide at Mauna Loa Observatory, Hawaii. In: Carbon Dioxide Review: 1982, CLARK, W. C. (Ed.). Oxford University Press, pp. 377-385, 1982.

44. KEELING,C.D.; BACASTOW, R.B.; BAINBRIDGE, A.E.; EKDAHL, C.A.; GUENTHER, P.R.; WATERMAN, L.S. Atmospheric carbon dioxide variations at Mauna Loa Observatory. Hawaii: Tellus, vol. 28, 538-551, 1976.

45. SANDOR, R. L.; WALSH, M. J. Some observations on the evolution of the international greenhouse gas emissions trading market. In: KOSOBUD, R. F.; SCHREDER, D.L.; BIGGS, H.M. Emission trade: environmental policy's new approach. Hoboken: John Wiley \& Sons Inc, 2000.

46. THONING, K.W.; TANS, P.P.; KOMHYR, W.D. Atmospheric carbon dioxide at Mauna Loa Observatory. NOAA GMCC. 1974-1985, Geophysical Research, vol. 94, 8549-8565, 1989.

47. GOLDEMBERG, J.; VILLANUEVA, L. D. Energia, meio ambiente e desenvolvimento. São Paulo: Edusp 2005. 227 p. 
48. BENINCASA, M.; ORTOLANI, A. F.; LUCAS JUNIOR, J. Biodigestores convencionais. 2. ed. Jaboticabal: Faculdade de Ciências Agrárias e Veterinária, UNESP,1991. $25 \mathrm{p}$.

49. REZENDE, D.; MERLIN, S.; SANTOS, M. Sequestro de carbono: uma experiência concreta. 2.ed. Palmas: Instituto Ecológica, 2001. 178 p.

50. ROCHA, M. T. Como determinar os impactos da redução das emissões de carbono sobre a economia brasileira e os seus setores. In: Congresso brasileiro de economia e sociologia rural. Brasília: Sober, 2000.

51. THE INTERNATIONAL GEOSPHERE-BIOSPHERE PROGRAMME. IGBP. Terrestrial Carbon Working Group. The terrestrial carbon cycle: implications for the Kyoto Protocol. Science, v.280, n.5368, p.1393-1394, 1998.

52. TAYLOR,P. "How do we know we have global environmental problems? Undifferentiated science-politics and its potential reconstruction". In Changing Life: Genomes-Ecologies-Bodies-Commodities. TAYLOR, P.; HALFON, S.; EDWARDS, P. (Eds) Minneapolis: University of Minnesota Press. Pp. 149-174.

53. MAHAN, B. M. Química um Curso Universitário. 1. Ed. São Paulo: EdgarBlucher, 2003. 604 p.

54. PAULING, L. Quimica General Una Introducion a la Quimica descriptiva y a la moderna teoria química. Madrid: Aguilar, 1955. 694 p.

55. YU, C. M. Sequestro Florestal do Carbono no Brasil: dimensões políticas, sócio-econômicas e ecológicas. São Paulo: Annablume, 2004.

56. KITZIS, D.R.; CONWAY, T.J.; TANS, P.P.; WATERMAN, L.S.; Waterman, THONING, K.W. Evidence of interannual variability of the carbon cycle. NOAA/CMDL Global Air Sampling Network. Geophysical Research, vol. 99, 22831-22855, 1994.

57. EARTH OBSERVATORY- The Carbon Cycle. Disponível em: $<$ http://earthobservatory.nasa.gov/Features/CarbonCycle/carbon cycle4.ph p >. Acesso em: 22 jan. 2009.

58. INTERGOVERNMENTAL PANEL ON CLIMATE CHANGE. IPCC. Cambio Climático: evaluación científica del IPCC. Grupo Intergubernamental de Expertos sobre el Cambio Climático. Madri: Ed. Instituto Nacional de Meterologia \& Centro de Publicaciones Del Ministério de Obras Publicas y Transportes. 2004, p. 2. 
59. INTERGOVERNMENTAL PANEL ON CLIMATE CHANGE. IPCC. Sixteen Years of Scientific Assessment in Support of the Climate Convention. Geneva: IPCC Secretariat. 2004. Disponível em $<$ http://www.ipcc.ch/abpout/anniversarybrochure.pdf>. Acesso em: 29 nov. 2006.

60. UNITED NATIONS FRAMEWORK CONVENTION ON CLIMATE. UNFCCC. Updated reporting guidelines on annual inventories following incorporation of the provisions. Decision 14/CP.11. Disponível em: : $<$ http://unfccc.int/resource/docs/2006/sbsta/eng/09.pdf>. Acesso em: 29 jun. 2008.

61. CONVENÇÃO-QUADRO DAS NAÇÕES UNIDAS SOBRE MUDANÇAS DO CLIMA. Página Oficial CQNUMC. Disponível em: <http://www.mct.gov.br>. Acesso em: 25 maio 2006.

62. FRAMEWORK CONVENTION ON CLIMATE CHANGE; FCCC/CP/1996/15/Add.1; 29 October 1996; Report of the Conference of the Parties at its second session. Revised Guidelines for the Preparation of National Communications by Parties Included in Annex I to the Convention, p18. Geneva 1996.

63. MARIANO C. CENAMO. Mudanças Climáticas, o Protocolo de Kyoto e - Mercado de Carbono; Piracicaba. Escola Superior Agricultura Luis de Queroz e Centro de Estudos Avançados em Economia Aplicada. ESALQ CEPEA. Fev. 2004.

64. MASKELL, K.; JOHNSON, C. A.; HOUGTHON, J. T.; DING, Y.; GRIGGS, D. J. Climate Change 2001: A Scientific Basis, IPCC. Cambridge University Press. Cambridge, U.K. IPCC 2001.

65. CONVENÇÃO-QUADRO DAS NAÇÕES UNIDAS SOBRE MUDANÇA DO CLIMA. CQNUMC. Unidade de Informações sobre Mudança do Clima (PNUMA) (IUC). Secretariado Permanente da Convenção. Disponível em: <http://www.mct.gov.br/clima/convencao.htm >. Acesso em: 12 nov. 2004.

66. INTERGOVERNMENTAL PANEL ON CLIMATE CHANGE. IPCC. Climate Change 2001: The Scientific Basis - Contribution of Working Group I to the Third Assessment Report of the IPCC. Cambridge: Cambridge University Press. 2001.

67. NOGUER, M.; GRIGGS, D. J. ; MASKELL, K. JOHNSON, C. A ; HOUGHTON, J.T.; DING, Y.; VAN DER LINDEN, P. J. Climate Change 2004: The scientific basis. IPCC. Cambridge: Cambridge University Press, 2001 a. $881 \mathrm{p}$. 
68. UNITED NATIONS FRAMEWORK CONVENTION ON CLIMATE CHANGE: The First Ten Years. Bonn, Germany: Climate Change Secretariat. Database to UNFCCC 2004.

69. INTERGOVERNMENTAL PANEL ON CLIMATE CHANGE. Climate Change 2002: The Scientific Basis - Contribution of Working Group II to the Third Assessment Report of the IPCC. Cambridge: Cambridge University Press. 2003.

Disponível em <http://www.ipcc.ch> Acesso em: 05 mar. 2006.

70. INTERGOVERNMENTAL PANEL ON CLIMATE CHANGE. Cambio Climático: evaluación científica del IPCC. Grupo Intergubernamental de Expertos sobre el Cambio Climático. Madri: Ed. Instituto Nacional de Meterologia \& Centro de Publicaciones del Ministério de Obras Publicas y Transportes. IPCC, 1990.

71. INTERGOVERNMENTAL PANEL ON CLIMATE CHANGE. Climate Change 2007: The Physical Science Basis. Cambridge Univ. Press, Cambridge UK and New York, NY USA. IPCC, 2007.

72. WORLD METEOROLOGICAL ORGANIZATION. Scientific Assessment of Ozone Depletion. Global Ozone Research and Monitoring Project. Report n‥ 44. Geneva, Switzerland. WMO, 1999.

73. CONVENÇÃO-QUADRO DAS NAÇÕES UNIDAS SOBRE MUDANÇA DO CLIMA. O Brasil e a Convenção Quadro das Nações Unidas sobre Mudança do Clima. CQNUMC. MCT. Disponível em: <http://www.mct.gov.br/clima/negoc/cop10.htm>. Acesso em: 17 abr. 2005.

74. UNITED NATIONS FRAMEWORK CONVENTION ON CLIMATE CHANGE. Calendário de encontros. UNFCCC, 2008. Disponível em: $<$ http://unfccc.int/meetings/unfccc calendar/items/2655.php?year=2008> Acesso em: 19 set. 2008.

75. UNITED NATIONS FRAMEWORK CONVENTION ON CLIMATE CHANGE. Parties to the Convention and Observer States. UNFCCC, 2004. Disponível em: $<$ http://unfccc.int/parties and observers/parties/items/2352.php $>$ Acesso em: 01 fev. 2009.

76. UNITED NATIONS FRAMEWORK CONVENTION ON CLIMATE CHANGE - List of Annex I Parties to the Convention. UNFCCC, 2004.

Disponível em: $<$ http://unfccc.int/parties and observers/parties/annex i/items/2772.php $>$ Acesso em: 21 set. 2009. 
77. UNITED NATIONS FRAMEWORK CONVENTION ON CLIMATE CHANGE. - List of Non-Annex I Parties to the Convention. UNFCCC, 2004. Disponível em: $<$ http://unfccc.int/parties and observers/parties/non annex i/items/2833.ph p >. Acesso em: 21 set. 2009.

78. SÉTIMA CONFERÊNCIA DAS PARTES, COP-7. Os Acordos de Marrakech - Fórum Brasileiro de Mudanças Climáticas - FBMC, MCT. Disponível em: <http://www.forumclimabr.org.br/acordos.htm>. e <http://www.mct.gov.br/clima/negoc/cop7.htm. Mar. de 2006>. Acesso em: 05 ago. 2009.

79. MAY, P. H.; LUSTOSA, M. C. Economia do Meio Ambiente. Rio de Janeiro: Campus, 2008.

80. WITKOWSKI, F. F.; GAZANI, F. R. O Mecanismo do Desenvolvimento Limpo. São Paulo: Fundação Peirópolis, 2008.

81. CENAMO, M. C. Mudanças Climáticas, o Protocolo de Kyoto e o Mecanismo de Desenvolvimento Limpo, 2004. Tese (Mestrado) Engenharia Florestal. ESALQ - Escola Superior de Agricultura Luiz Queiroz. SP.

82. VELDERS, G. J. M.; ANDERSEN, S. O.; DANIEL, J. S.; FAHEY, D. W.; MCFARLAND, M. (2007): The importance of the Montreal Protocol in protecting climate. Nat. Acad. Sciences 104, 4814-4819.

83. FRAMEWORK CONVENTION ON CLIMATE CHANGE. Conference of Parties: First Session. Berlin, Germany, 1995/7/Add.1. FCCC, 2004. Disponivel em <http://unfccc.int/resource/docs/cop1/07a01.pdf >. Acesso em: 23 set. 2009.

84. FRAMEWORK CONVENTION ON CLIMATE CHANGE. Conference of Parties: Second Session. Geneva, Switzerland, 1996/15/Add.1 - FCCC, 2004. Disponível em: <http://unfccc.int/resource/docs/cop2/15a01.pdf> Acesso em: 23 set. 2009.

85. UNITED NATIONS FRAMEWORK CONVENTION ON CLIMATE CHANGE. Official web site of the Third Conference of the Parties, Kyoto, Japan, UNFCCC, 1977. Disponível em: < http://unfccc.int/cop3/>. Acesso em: 24 set. 2009. 
86. FRAMEWORK CONVENTION ON CLIMATE CHANGE. Conference of Parties - Fourth Session. Buenos Aires, Argentina, 1998/16/Add.1 FCCC, 1998. Disponível em: $<$ http://unfccc.int/resource/docs/cop4/16a01.pdf>. Acesso em: 24 set. 2009.

87. INGARAMO, J.; SIERRA, E. El Marco Legal del Mecanismo de Desarollo Limpio (MDL). Buenos Aires: Instituto de Estúdios Econômicos da Bolsa de Cereales. 2005. Disponível em: $<$ http://www.bolcereales.com.ar/basepdf.asp?pag=Marco Legal.pdf $>$. Acesso em: 12 jan. 2007.

88. UNITED NATIONS FRAMEWORK CONVENTION ON CLIMATE CHANGE. Conference of Parties: Fifth Session. Bonn, Germany. UNFCCC, 1999. Disponível em: <http://unfccc.int/cop5/>. Acesso em: 24 set. 2009.

89. UNITED NATIONS FRAMEWORK CONVENTION ON CLIMATE CHANGE. Conference of Parties: Sixth Session. UNFCCC, 2000. The Hague, Netherlands. Disponível em: <http://unfccc.int/cop6/>. Acesso em: 26 set. 2009.

90. UNITED NATIONS FRAMEWORK CONVENTION ON CLIMATE CHANGE. Conference of Parties: Sixth Session, Part 2, Bonn, Germany. UNFCCC, 2001. Disponível em: <http://unfccc.int/cop6 2/index.html>. Acesso em: 26 set. 2009.

91. UNITED NATIONS FRAMEWORK CONVENTION ON CLIMATE CHANGE. Conference of Parties: Seventh Session, Marrakech, Maroc. UNFCCC, 2001. Disponível em: <http://unfccc.int/cop7/>. Acesso em 27 set. 2009.

92. UNITED NATIONS FRAMEWORK CONVENTION ON CLIMATE CHANGE. Conference of Parties: Eigth Session, New Delhi, India, 2002/7/Add1. UNFCCC, 2007. Disponível em: $<$ http://unfccc.int/resource/docs/cop8/07a01.pdf>. Acesso em: 27 set. 2009.

93. UNITED NATIONS FRAMEWORK CONVENTION ON CLIMATE CHANGE. Conference of Parties: Ninth Session, Milan, Italy. UNFCCC, 2003. Disponível em: <http://unfccc.int/cop9/>. Acesso em: 27 set. 2009.

94. CLEAN DEVELOPMENT MECHANISM EXECUTIVE BOARD. Clean Development Mechanism Simplified Project Design Document for Small Scale Project Activities: "Pesqueiro Energia Small Hydroelectric Project". Disponível em <http://cdm.unfccc.int/Projects/registered.html>. Acesso em 07 dez. 2006. 
95. UNITED NATIONS FRAMEWORK CONVENTION ON CLIMATE CHANGE. Conference of Parties: Tenth Session. Buenos Aires, Argentina. UNFCCC, 2004. Disponível em: $<$ http://unfccc.int/meetings/cop 10/items/2944.php >. Acesso em: 27 set. 2009.

96. BARAN, F.D. Avaliação de uma Floresta de Eucaliptos na Presença de um Mercado de Certificados para Reduções de Emissões de Carbono: Uma Abordagem por Opções Reais. 2005. Dissertação (Mestrado) Pontifícia Universidade Católica do Rio de Janeiro, Rio de Janeiro.

97. UNITED NATIONS FRAMEWORK CONVENTION ON CLIMATE CHANGE. Conference of Parties: Eleventh Session. Montreal, Canada. UNFCCC, 2005. Disponível em: < http://unfccc.int/meetings/cop 11/items/3394.php > Acesso em: 27 set. 2009.

98. UNITED NATIONS FRAMEWORK CONVENTION ON CLIMATE CHANGE. Conference of Parties: Twelfth Session, Nairobi, Kenya. UNFCCC, 2006. Disponível em: <http://unfccc.int/meetings/cop 12/items/3754.php>. Acesso em: 28 set. 2009.

99. UNITED NATIONS FRAMEWORK CONVENTION ON CLIMATE CHANGE. Conference of Parties: Thirteenth Session, Bali, Indonesia. UNFCCC, 2007. Disponível em:

$<$ http://unfccc.int/meetings/cop 13/items/4049.php>. Acesso em: 28 set. 2009.

100. UNITED NATIONS FRAMEWORK CONVENTION ON CLIMATE CHANGE. Conference of Parties: Fourteenth Session, Poznań, Poland. UNFCCC, 2008. Disponível em:

$<$ http://unfccc.int/meetings/cop 14/items/4481.php $>$. Acesso em: 28 set. 2009.

101. LORA, E. E. S. Prevenção e Controle da Poluição nos Setores Energético, Industrial e de Transporte. Rio de Janeiro: Interciência. 2000.

102. UNITED NATIONS FRAMEWORK CONVENTION ON CLIMATE CHANGE. Protocolo de Kyoto, UNFCCC. 2. ed. Brasília: MCT, 2001.

103. INTERGOVERNMENTAL PANEL ON CLIMATE CHANGE. Climate Change 2001: The Scientific Basis. Cambridge Univ. Press. Cambridge UK and New York, NY USA. IPCC, 2002. 
104. ELLERMAN, A. D.; DECAUX, A. Analysis of Kyoto Protocol and $\mathrm{CO}_{2}$ emissions trading using marginal abatement curves. Cambridge: MIT, 1998. 32p. (MIT Report, 40).

105. UNITED NATIONS FRAMEWORK CONVENTION ON CLIMATE CHANGE. Status of ratification. UNFCCC, 2004. Disponível em:

$<$ http://unfccc.int/essential background/convention/status of ratification/ite ms/2631.php>. Acesso em: 05 ago. 2006.

106. FRAMEWORK CONVENTION ON CLIMATE CHANGE. Modalidades e Procedimentos para atividades de projeto no MDL - Primeiro período de compromisso do Protocolo de Kyoto. Decisão 10/CP.9 FCCC/CP/2003/6/Add.2. Convenção-Quadro das Nações Unidas sobre Mudanças do Clima, CQNUMC, 2003.

107. THE UNITED NATIONS FRAMEWORK CONVENTION ON CLIMATE CHANGE - Full Text of the Convention-Article 1-Definitions. UNFCCC, 2006. Disponível em:

$<$ http://unfccc.int/essential background/convention/background/items/1353. php> Acesso em 05 nov. 2007.

108. NEW YORK TIMES. London. China overtakes U.S. in greenhouse gas emissions. New York Times, London, 06 jun. 2007. World Business.

109. ELLERMAN, A. D. ; JACOBY, H. D.; DECAUX, A. The effects on developing countries os the Kyoto Protocol and $\mathrm{CO}_{2}$ emission trading. Cambridge: MIT, 1998, 42p. (MIT Report, 41).

110. CENTER FOR GLOBAL DEVELOPMENT. China passa E.U., é líder mundial em emissões de carbono do Setor Elétrico - CGD, 2008. Disponível em: <http://www.cgdev.org/content/article/detail/16578/>. Acesso em: 30 set. 2009.

111. ENERGY INFORMATION ADMINISTRATION. International Energy Annual 1999 DOE/EIA - 0219 (99) (Washington DC, January 2001). Projections: EIA, World Energy Projection System 2001.

112. LOPES, I. V. O Mecanismo de Desenvolvimento Limpo - MDL: guia de orientação. Rio de Janeiro: FGV, 2002.

113. PEREIRA, A. S. Do Fundo ao Mecanismo: Gênese, Características e Perspectivas para o Mecanismo de Desenvolvimento Limpo; ao Encontro ou de Encontro à Eqüidade? 2002. Dissertação (Mestrado) em Planejamento Energético. Universidade Federal do Rio de Janeiro, Rio de Janeiro. 
114. FOLHA DE SÃO PAULO. Rússia aprova ratificação do Protocolo de Kyoto. Folha de São Paulo. São Paulo, 30 set. 2004. Disponível em: $<$ http://www1.folha.uol.com.br/folha/mundo/ult94u77037.shtml> Acesso em 30 ago. 2007.

115. BRASIL. Decreto Presidencial de 07 de julho de 1999, Diário Oficial, 08 de Julho de 1999.

116. DUBOIS, S. M. O cumprimento do Protocolo de Kyoto sobre Alterações Climáticas. Synthèse, $\mathrm{n}^{\circ} 01$, de 2007 , do Instituto para 0 Desenvolvimento Sustentável e Relações Internacionais.

117. UNITED NATIONS FRAMEWORK CONVENTION ON CLIMATE CHANGE. UNFCCC. Data exchange standards for registry systems under the Kyoto Protocol technical specifications (version 1.1). DES, 1977. Disponível em: <http://unfccc.int/files/kyoto mechanisms/registry systems/application/ pdf/des tech spec ver 1 final.pdf $>$. Acesso em: 12 dez. 2006.

118. UNITED NATIONS FRAMEWORK CONVENTION ON CLIMATE CHANGE. UNFCCC. The Kyoto Protocol to the Framework Convention on Climate Change. 1977. Disponível em: $<$ http://unfccc.int/essential background/ kyoto protocol/background/items/1351.php>. Acesso em: 15 jan. 2005.

119. MINISTÉRIO DA CIÊNCIA E TECNOLOGIA. MCT. Status atual das atividades de projeto no âmbito do Mecanismo de Desenvolvimento Limpo no Brasil e no mundo. Brasília, DF: MCT, 2006.

120. FOGEL, C. 2004. The Local, the Global and the Kyoto Protocol. In: JASANOFF, S.; MATELLO, M. (Eds). Earthly Politics. Cambridge: MIT Press. p. 103-125.

121. MINISTÉRIO DAS RELAÇÕES EXTERIORES. MRT. Divisão de Atos Internacionais, Decreto Legislativo nr. 144, de 20/06/2002 - Protocolo de Kyoto à Convenção-Quadro das Nações Unidas sobre Mudança do Clima. MRE, 2002. Disponível em: $<$ http://www.onu-brasil.org.br/doc quioto2.php>. Acesso em: 25 out. 2006.

122. CONVENÇÃO-QUADRO DAS NAÇÕES UNIDAS SOBRE MUDANÇA DO CLIMA. CQNUMC. Diretrizes para a implementação do artigo 6 do Protocolo de Quioto. Decisão 16/CP.7 FCCC/CP/ 2001/13/Add.2; 5-7. CQNUMC, 2002. 
123. MINISTÉRIO DAS RELAÇÕES EXTERIORES. MRT. Nações Unidas do Brasil - Divisão de Atos Institucionais - Protocolo de Quioto à Convenção-Quadro das Nações Unidas sobre Mudança do Clima Decreto Legislativo nr. 144, de 20/06/2002 - Ratificado pelo Brasil em $23 / 08 / 2002$.

124. UNITED NATIONS FRAMEWORK CONVENTION ON CLIMATE CHANGE. UNFCCC. Background Paper B - Meeting the Targets. (15th Conference of the Parties - Copenhagen Protocol) - Asia-Pacific Model United Nations Conference-The University of Queensland. AMUNC, 2009.

125. CONVENÇÃO DO QUADRO DAS NAÇÕES UNIDAS SOBRE MUDANÇA DO CLIMA. CQNUMC. Climate change secretariat. Genebra, Suíça. Texto oficial. UNFCCC, 1999. Disponível em: $<$ http://unfccc.int/resource/doos/convenkp/pdf >. Acesso em: 15 abr. 2005.

126. UNITED NATIONS CONFERENCE ON TRADE AND DEVELOPMENT. Mecanismo de Desenvolvimento Limpo. Fundação Getúlio Vargas. Editado sob o patrocínio da UNCTAD. Dez, 2004.

127. BANCO NACIONAL DE DESENVOLVIMENTO ECONÔMICO E SOCIAL. O Mecanismo de Desenvolvimento Limpo. BNDES, 2002.

128. UNITED NATIONS FRAMEWORK CONVENTION ON CLIMATE CHANGE. UNFCCC. Activities Implemented Jointly (AIJ). UNFCCC, 2000. Disponível em: <http://unfccc.int/program/coop/aijproj.html>. Acesso em: 03 nov. 2005.

129. ANDERSON, D: ROLAND, K.; SCHREINER, P.; SKJELVIK, J. M. Designing a domestic GHG emission trading system: the example od Norway. In: JEPMA, C. J. ; VAN DER GAAST, W. On the compatibility of flexible instruments. Dordrecht: Kluwer Academic Publishers, 9, p. 109124. 1999.

130. GAZANI, F. R. ; FRANGETTO, F. W.; Mecanismo de Desenvolvimento Limpo (MDL). São Paulo: Fundação de Peirópolis, 2000.

131. GODOY, S. G. M. O Protocolo de Kyoto e o Mecanismo de Desenvolvimento Limpo: uma avaliação de suas possibilidades e limites. 2005. Dissertação (Mestrado em Economia Política) - Pontifícia Universidade Católica de São Paulo. São Paulo, 2005.

132. WORLD BANK. Estimating Portencial Market for Clean Development Mechanism. State and Trends of the Carbon Market. 2005. Disponível em: <http://carbonfinance.org/pcf/>. Acesso em: junho de 2005. 
133. MACEDO, Z. L. Os limites da economia na gestão ambiental. Revista Margem, São Paulo, Vol. 15, jun 2002.

134. VALLE, C. E. Qualidade ambiental: ISO 14.000. 4⿳亠丷a ed. São Paulo: SENAC, 2002. São Paulo: Pioneira, 2002.

135. CONVENÇÃO QUADRO DAS NAÇÕES UNIDAS SOBRE MUDANÇA DO CLIMA. Convenções e Tratados - Protocolo de Kyoto. Nações Unidas do Brasil. CQNUMC. Disponível em:

<http://www.onu-brasil.org.br/doc quioto.php>. Acesso em: 13 ago. 2007.

136. UNITED NATIONS FRAMEWORK CONVENTION ON CLIMATE CHANGE. CDM: Project Activities Interactive Map. UNFCCC, 2007. Disponível em: $<$ http://cdm.unfccc.int/Projects/MapApp/index.html> Acesso em: 02 set. 2009.

137. SOUZA, G. D. Aplicação do Mecanismo de Desenvolvimento Limpo: 0 Caso Nova Gerar. 2007. Dissertação (Mestrado) - Programa de PósGraduação em Geografia Humana do Departamento de Geografia da FFLCH/USP, São Paulo.

138. NOVA GERAR. Homepage da empresa. Disponível em: $<\underline{\text { http://www.nova }}$ gerar.com.br>. Acesso em: 21 set. 2007.

139. RELATÓRIO DE DCP - Documento de Concepção do Projeto - $n^{\circ}$ 001/2004 - Projeto Nova Gerar - Projeto de Energia a partir de Gases de Aterro Sanitário. Disponível em: $<$ http://www.mct.gov.br/index.php/content/view/16045.html>. Acesso em: 12 set. 2009.

140. USHIMA, A. H. "Modelagem e simulação de pirólise e secagem de biomassa em um gaseificador de leito contracorrente. 1996. Tese (Mestrado) - Universidade Estadual de Campinas, Faculdade de Engenharia Mecânica. 2 vol, pp. 158, 1996.

141. GAMEZ, M. Os bilhões do Carbono. In: Revista ISTO É. Caderno Economia e Negócios. 16 de agosto 2007.

142. MINISTÉRIO DE MINAS E ENERGIA. Portal CONPET - Programa nacional da Racionalização do uso dos derivados do petróleo e do gás natural. MME, 2007. 
143. FERNANDEZ, P. Projeto Nova Gerar de Conversão de Gases de Aterro em Energia dentro do Mecanismo de Desenvolvimento Limpo - MDL. Disponível em: $<$ http://www.bayer.com.br/byee/home.nsf/04bbd938b0f97149c1256ac5005 64711/83256e850068df8283256f2e00 3d38c8/\$FILE/projeto\%20Pablo\%20Fernandez.pdf >. Acesso em 03 mai. 2009.

144. MARCOVITCH, J. Para Mudar o Futuro: Mudanças Climáticas, Políticas Públicas e Estratégias Empresariais. São Paulo, Edusp/ Saraiva. 2006.

145. FRANGETTO, F.W.; GAZANI, F.R. Viabilização jurídica do mecanismo de desenvolvimento limpo (MDL) no Brasil: o Protocolo de Kyoto e a cooperação internacional. São Paulo: Peirópolis; Brasília, DF: Instituto Internacional de Educação do Brasil (IIEB), 2002.

146. FUNDAÇÃO BRASILEIRA PARA O DESENVOLVIMENTO SUSTENTÁVEL /FINEP - Financiadora de Estudos e Projetos - Workshop - As Mudanças Globais e as oportunidades para a indústria brasileira e mundial. FBDS - São Paulo. Agosto 2001.

147. SHELLARD, S.N.; MOZZER, G.B.; MAGALHÃES, D. A. Estrutura institucional do Mecanismo do Desenvolvimento Limpo. In: SOUZA, R.P. S. Aquecimento Global e Créditos de Carbono - Aspectos Jurídicos e Técnicos. São Paulo: Quartier Latin, 2007.

148. MINISTÉRIO DA CIÊNCIA E TECNOLOGIA - Decreto Presidencial "Dispõe sobre o CIMGC e as normas jurídicas federais diretamente relacionadas à implementação do MDL - a Política Nacional de Mudanças Climáticas - PNMC, seus princípios, objetivos e instrumentos" - Criação em de 7 de julho de 1999, alterado pelo Decreto de 10 de janeiro de 2006. MCT. Disponível em: <http://www.mct.gov.br.>. Acesso em: 25 de nov. de 2007.

149. BRASIL. Protocolo de Quioto e Legislação Correlata. Coleção Ambiental - v.3. Senado Federal. Brasília: Subsecretaria de Edições Técnicas, 2004.

150. GUIMARÃES, R. L. Compreendendo o mecanismo de desenvolvimento limpo. Boletim da Sociedade Brasileira de Economia Ecológica. n.2. Campinas: UNICAMP, 2007.

151. COMISSÃO INTERMINISTERIAL DE MUDANÇA GLOBAL DO CLIMA. Anexo III, em conformidade com o Artigo 12.2 do Protocolo de Kyioto, Convenção-Quadro das Nações Unidas sobre Mudança do Clima" (Art. 3.1 Resolução ํo 1 CIMGC). 
152. UNITED NATION FRAMEWORK CONVENTION ON CLIMATE CHANGE, Overview of Project Activity Cycle. UNFCCC, 2000. Disponível em: $<$ http://unfccc.int/cdm/dmprojslide.html>. Acesso em: 5 ago. 2008.

153. MAROUN, M. R. Adaptação às Mudanças Climáticas: uma proposta de documento de concepção de projeto (DCP) no âmbito do mecanismo de desenvolvimento limpo (MDL). 207. Dissertação (Mestrado) Universidade Federal do Rio de Janeiro, Rio de Janeiro.

154. SATHAYE, J.; MURTISHAW, J.S.; PRICE, L.; LEFRANC, M.; ROY, J.; WINKLER, H.; SPALDING- FECHER, R. Multiproject baselines for evaluation of electric power projects. Lawrence Berkeley National Laboratory (paper LBLN-51917). 2002.

155. INTERGOVERNMENTAL PANEL ON CLIMATE CHANGE. Summary for Policymakers. In: Climate Change 2007: The Physical Science Basis. Contribution of Working Group I to the Fourth Assessment Report: 2007.

156. CLEAN DEVELOPMENT MECHANISM EXECUTIVE BOARD.

Approved Consolidated Baseline Methodology ACM0002: Consolidated Baseline Methodology for Grid-Connected Electricity From Renewable Sourses. Versão 6, Maio 2006. Disponível em:

$<$ http://cdm.unfccc.int/methodologies/PAmethodologies/approved.html>. Acesso em: 14 dez. 2006.

157. BOSI, M. An Initial View on Methodologies for Emission Baselines: Electricity Generation Case Study, Information Paper, Organisation for Economic Co-operation and Development, 2001.

158. UNITED NATIONS FRAMEWORK CONVENTION ON CLIMATE CHANGE Baseline and monitoring methodologhies. UNFCCC, 2000. Disponível em: <http://cdm.unfccc.int/methodologies $>$. Acesso em 2 jul. 2005.

159. FRONDIZI, M. R. I. O mecanismo de desenvolvimento limpo: guia de orientação. São Paulo: Imperial Novo Milênio - FIDES, 2009.

160. CONSELHO EMPRESARIAL BRASILEIRO. Modelo de Documento de Concepção de Projeto. ICF Consulting. 2003. Disponivel em: $<$ http://cdm.unfccc.int/methodologies/PAmethodologies/index.html>. Acesso em: 3 mai. 2007.

161. COSBEY, A. Defining and Measuring the Development Dividend. In: Making Development Work in the CDM: phase II of the development dividend project. Winnipeg: International Institute for Sustainable Development. Disponível em: <http://www.iisd.org. $>$ Acesso em dezembro de 2006>. 
162. CENTRO DE GESTÃO E ESTUDOS ESTRATÉGICOS. Confederação Nacional da Indústria - Ciência, Tecnologia e Evolução - Manual de Capacitação sobre Mudança do Clima e Projetos de Mecanismo de Desenvolvimento Limpo (MDL) - CGEE/MCT/CNI Brasília, DF: 2008.

163. COMISSÃO INTERMINISTERIAL SOBRE MUDANÇA GLOBAL DO CLIMA. Art. 3.1 Resolução no 1 - Artigo 12.2 do Protocolo de Kyoto à Convenção-Quadro das Nações Unidas sobre Mudança do Clima CQNUMC - CIMGC, 2003.

164. ASOCIACIÓN ESPAÑOLA DE LA INDÚSTRIA ELÉCTRICA - UNESA. Metodologías para la Implementación de los Mecanismos flexibles de Kyoto Mecanismo de Desarrollo Limpio en Latinoamérica, 2006.

165. CLEAN DEVELOPMENT MECHANISM EXECUTIVE BOARD. CDM Project Design Document Form: "Poechos I". Disponível em: $<$ http://cdm.unfccc.int/Projects/registered.html. $>$ Acesso em: 24 jan. 2006.

166. MAGALHÃES, D. de A.; MOZZER, G.B.; SHELLARD, S.N. As atividades de projeto no âmbito do Mecanismo do Desenvolvimento Limpo no Brasil. In: SOUZA, R.P. S. Aquecimento Global e Créditos de Carbono Aspectos Jurídicos e Técnicos. São Paulo: Quartier Latin, 2007.

167. MOZZER, G.B.; MAGALHÃES, D. A.; SHELLARD, S.N. Ciclo de submissão de projetos MDL e emissão de RCE (Reduções Certificadas de Emissões). São Paulo. 2002.

168. INSTITUTO BRASILEIRO DE RELAÇÕES COM INVESTIDORES. Carbon Disclosure Project Relatório 2008. América Latina Relatório produzido por: Fábrica Éthica Brasil - Consultoria em Sustentabilidade (Facilitador Continental), IBRI.2008.

169. ASSOCIAÇÃO BRASILEIRA DE EMPRESAS DE LIMPEZA PÚBLICA E RESÍDUOS. Especiais Panorama dos Resíduos Sólidos no Brasil. ABRELPE - 2007 Mecanismo de Desenvolvimento Limpo - MDL. Disponivel em: <http://www.abrelpe.org.br/pdf/8 MDL.pdf>. Acesso em: 12 jan. 2008.

170. MINISTÉRIO DO MEIO AMBIENTE, Japão - Manual do MDL para desenvolvedores de projeto e formuladores de políticas - Fundação do Centro Global para o Meio Ambiente, 2006. 
171. CLEAN DEVELOPMENT MECHANISM EXECUTIVE BOARD.

Appendix B of the Simplified Modalities and Procedures for SmallScale CDM Project Activity Categories, Type I (AMS-I.D) - Renewable Energy Projects: “Grid Connected Renewable Electricity Generation”, Versão 9, Julho 2006. Disponível em:

$<$ http://cdm.unfccc.int/methodologies/SSCmethodologies.html>. Acesso em 13 dez. 2006.

172. XAVIER, L.N.; DINIZ, A.L.; COSTA, F.S.; MACEIRA, M.E.P. Aprimoramento da Modelagem da Função de Produção Energética das Usinas Hidroelétricas no Modelo DECOMP: Metodologia e Resultados, XVIII SNPTEEE, Curitiba, Outubro de 2005.

173. CLEAN DEVELOPMENT MECHANISM EXECUTIVE BOARD. Clean Development Mechanism Project Design Document Form: "La Higuera Hydroelectric Project". Disponível em:

$<$ http://cdm.unfccc.int/Projects/registered.html>. Acesso em: 2 fev. 2006.

174. UNEP RISO CENTRE. Climate and Sustainable Development. United Nations Environment Programme Division of Technology, Industry, and Economics - Global Trends in Sustainable Energy Investment Report , 2009.

175. MICHAELOWA, A. Climate Strategies Empirical analysis of performance of CDM projects: FINAL REPORT. Climate Strategies c/o University of Cambridge, 13-14 Trumpington Street, Cambridge, CB2 1QA, UK, 2006.

176. UNEP RISO CENTRE/UNEP. CDM/JI Pipeline Analysis and Database. Energy, Climate and Sustainable Development - CD4 CDM - Capacity Development For The Clean Development Mechanism. Disponível em $<$ http://cdmpipeline.org/>. Acesso em: 12 out. 2009.

177. FEDERAÇÃO DAS INDÚSTRIAS DO ESTADO DO RIO DE JANEIRO. Boletim do escritório de Carbono Fórum no Rio Ambiente 2009 Junho FIRJAN-, 2009.

178. UNITED NATIONS DEVELOPMENT PROGAMME. The Clean Development Mechanism - an assessment of progress. UNPD, 2006. Disponível em: <http://www.undp.org/climatechange>. Acesso em 12 abr. 2008.

179. UNITED NATIONS DEVELOPMENT PROGAMME. Adaptado de IKOTEMA - Soluções tecnológicas por Flavia Witkowski Frangetto, 2008. 
180. AGÊNCIA NACIONAL DE ENERGIA ELÉTRICA. Banco de Informações da Geração: Matriz de Energia Elétrica. ANEEL. Disponível em:

<http://www.aneel.gov.br/area.cfm?idArea=15 > . Acesso em: 2 nov. 2007.

181. BOSI, M.; LAURENCE, A.; MALDONADO, P.; SCHAEFFER, R.SIMOES, A.F.; WINKLER, H.; LUKAMBA, J. M. Road testing baselines for greenhouse gas mitigation projects in the electric power sector. International Energy Agency/Organization for the Economic Cooperation and Development, 2002.

182. EMPRESA DE PESQUISA ENERGÉTICA. Balanço Energético Nacional 2007. Ano Base 2006 (Resultados Preliminares). BEN/MME. Rio de Janeiro, BRASIL: Empresa de Pesquisa Energética /EPE. 2007.

183. THE GREENHOUSE GAS PROTOCOL INITIATIVE / WRI / WBCSD. GHG Protocol. Normas internacionais de monitoramento e comunicação das emissões de GEE. GHG / World Resources Institute / World Business Council for Sustainable Development. Disponível em: <www.ghgprotocol.org>. Acesso em: 2 jul. 2009.

184. THE GREENHOUSE GAS PROTOCOL INITIATIVE - The foundation for sound and sustainable climate strategies - GGP. Disponível em: <http://www.ghgprotocol.org/> Acesso em: 10 jan. 2009.

185. PAINEL INTERGOVERNAMENTAL DE MUDANÇAS CLIMÁTICAS. Relatório da IPCC/ONU - Novos Cenários Climáticos. Conferência Latino-Americana sobre Meio Ambiente e Responsabilidade Social. Paris. 02/02/1007.

186. SUMÁRIO EXECUTIVO DO RELATÓRIO. Mudanças climáticas e segurança energética no Brasil. Assessoria de Comunicação da Coppe/UFRJ com o apoio da Embaixada do Reino Unido. 2008, Rio de Janeiro: Gráfica Nova Brasileira. 35 p.

187. PAINEL INTERGOVERNAMENTAL DE MUDANÇAS CLIMÁTICAS. Intergovernmental Panel on Climate Change Special. Report on Emission Scenarios. Viena, 2000.

188. JONES, R. G.; NOGUER, M.; HASSEL, D.; HUDSSON, D.; WILSON, S.; JENKINS G.; MITCHEL, J. Generating high resolution climate change scenarios using Precis. Exeter, UK: Meteorological Office Hadley Centre, 2004.

189. ENERGY INFORMATION ADMINISTRATION. International Energy Annual 2006. EIA, World Energy Projections Plus (June-December 2008). Disponivel em: <www.eia.doe.gov/iea.Projections >. Acesso em: 12 jan.2009. 
190. TOURINHO, O.A.F. The Valuation of Reserves of Natural Resources: An Option Pricing Approach, University of California, Berkeley, PhD Dissertation, Novembro 1979.

191. YOUNG,E.J. "Which Way Ahead for China?" Energy Strategies for a Turbulent Economy: Perspectives from CERAWEEK 2009. Disponivel em: $<$ www.cera. com> . Acesso em: 15 mar. 2009.

192. ENERGY INFORMATION ADMINISTRATION. International Energy Outlook 2009 - Official Energy Statistics from the U.S. Government- Center for Strategic and International Studies Washington, DC. 2009.

193. OLIVEIRA, J. A. P. Meio Ambiente e desenvolvimento sustentável. In SCELZA, RUEDIGER, SOBREIRA. Desenvolvimento e construção nacional : políticas públicas. Ebape/FGV. Ed. FGV, 2005.

194. ORGANIZATION FOR ECONOMIC COOPERATION AND DEVELOPMENT. Economic Outlook n‥ 80. Paris, France, November 2006, Annex Table 21, OECD. "Potential GDP, Employment and Capital Stock,". Disponivel em: $<w w w . o e c d . o r g / d a t a o e c d / 5 / 49 / 37841330 . x l s>$. Acesso em: 15 fev. 2008.

195. EMPRESA DE PESQUISA ENERGÉTICA. Plano Nacional de Energia PNE 2030. 2007. Disponível em: $<$ http://www.epe.gov.br/Lists/Estudos/DispForm.aspx?|D=12>. Acesso em : 02 ago. 2007.

196. MINISTÉRIO DAS RELAÇÕES EXTERIORES. Relatório Brasileiro para a Cúpula Mundial para o Desenvolvimento Social. MRE. Séries, Cambrigde: University Press, 1995.

197. INSTITUTO NACIONAL DE PESQUISAS ESPACIAIS. Caracterização do clima atual e definição das alterações climáticas para o território brasileiro ao longo do século XXI. Relatório n. 6: Mudanças climáticas e possíveis alterações nos biomas da América do Sul. São Paulo: CPTEC/INPE, 2007.

198. BEYOND PETROLIUM. Statistical Review of World EnergyJune 2009 Relatório Energy matters. BP. Disponivel em: $<$ http://www.bp.com/productlanding.do?categoryld=6929\&contentld=70446 22>.Acesso em: 02 set. 2009. 
199. AGÊNCIA NACIONAL DE ENERGIA ELÉTRICA - Banco de Informações de Geração. 2007a. Disponível em:

$<$ http://www.aneel.gov.br/area.cfm?idArea=15 \&idPerfil=2>. Acesso em: 18 set. 2009.

200. MINISTÉRIO DE MINAS E ENERGIA. Balanço energético nacional 2006. Rio de Janeiro: EPE Empresa de Pesquisa Energética, MME - 2006.

201. MARLAND, G.; BODEN, T. A.; ANDRES, R. J. Global. Regional, and National CO2 Emissions, Trends: A Compendium of Data on Global Change (Oak Ridge, TN: Carbon Dioxide Information Analysis Center, 2007); BP, Statistical Review of World Energy. London: 2007.

202. MASARIE, K.A.; TANS, P.P. Extension and integration of atmospheric carbon dioxide data into a globally consistent measurement record. J. Geophysics Research. vol. 100, 11593-11610, 1995.

203. HOFMANN, D. J.; BUTLER, J. H.; DLUGOKENCKY, E. J. The role of carbon dioxide in climate forcing from 1979 - 2004: Introduction of the Annual Greenhouse Gas Index. Tellus B, 58B, 614-619, 2006.

204. GLOBAL REPORTING INITIATIVE. Sustainability Reporting Guidelines. GRI, 2002.

205. THE GREENHOUSE GAS PROTOCOL A Corporate Accounting and Reporting Standard Revised edition - BP. Environmental Performance: Group Reporting Guidelines, Version 2.2, 2000.

206. PETROLEUM INDUSTRY GUIDELINES. Reporting Greenhouse Gas Emissions. International Petroleum Industry Environmental Conservation Association. IPIECA - London, 2003.

207. BEYOND PETROLIUM. BP Statistical Review of World Energy 2009. Comunicado de imprensa sobre o relatório. BP. 2009.

208. U. S. GEOLOGICAL SURVEY- Science for a Changing world-Statistics and Information Cement. EU - USGS, 2009. Disponivel em: $<$ http://minerals.usgs.gov/minerals/pubs/commodity/cement>. Acesso em: 02 jul. 2009.

209. ENERGY INFORMATION ADMINISTRATION. E.U. Departament of Energy - EIA U.S. Carbon Dioxide Emissions from Energy Sources 2008 Flash Estimate. May 2009. 
210. MINISTÉRIO DA CIÊNCIA E TECNOLOGIA - Coordenação-Geral de Mudanças Globais. Comunicação Nacional Inicial do Brasil à Convenção-Quadro das Nações Unidas Sobre Mudança do Clima. MCT - SEPED-Secretaria de Políticas e Programas de Pesquis e Desenvolvimento - Brasília, Novembro de 2004.

211. EGGLESTON, H.S.; BUENDIA, L.; MIWA, K.; NGARA, T.; TANABE K. NGGIP (National Greenhouse Gas Inventories Progamme) IPCC, 2006. Inventários Nacionais de Gases de Efeito Estufa. IGES, Japan.

212. GLOBAL ENVIRONMENT FACILITY. Apresentação de Propostas de Projeto para o Programa do Fundo Global para o Meio Ambiente. GEF/MCT/ASCAP- Assessoria de Captação de Recursos, 2003.

213. COMITÊ INTERMINISTERIAL SOBRE MUDANÇA DO CLIMA. GOVERNO FEDERAL . Decreto o 6.263 de 21 de novembro de 2007. PLANO NACIONAL SOBRE MUDANÇA DO CLIMA - PNMC - Versão para Consulta Pública Setembro, 2008.

214. IBGE - Instituto Brasileiro de Geografia e estatística - PIB - Produto Interno Bruto. Taxa Média Anual de Crescimento do Produto Interno Bruto Média Geométrica por Período Brasil - 1995 - 2008. Disponível em: $<$ http://www.sei.ba.gov.br/index.php?option=com content\&view=article\&id= 135\&ltemid=218 $>$. Acesso em: 10 out. 2009.

215. FUNDAÇÃO DE AMPARO À PESQUISA DO ESTADO DE MINAS GERAIS. Economia e Energia. Progressos na Matriz Energética e de Emissões de Gases Causadores do Efeito Estufa. FAPEMIG. Disponível em: <http://ecen.com/matriz/eee23/emister.htm > Acesso em: 23 jun. 2009.

216. BEN - Balanço Energético Nacional de 2008 - Resultados Preliminares (ano base 2007). - EPE - Empresa de Pesquisas Energéticas - MME MINISTÉRIO DE MINAS E ENERGIA. Disponível em: $<$ http://www.worldenergy.org/documents/resultados pre ben 2008.pdf> Acesso em: 12 set. 2009.

217. AMERICAN PETROLEUM INSTITUTE. Compendium of Greenhouse Gas Emissions Estimation Methodologies for the Oil and Natural Gas Industry. Disponível em: <http://engineers. ihs.com/news/climatechange/2009/api-ghg-estimation-compendium-090909.htm >. Acesso em: 15 set. 2009.

218. METZ, B.; DAVUDSON, O.; LOOS, M.. Special Report on Carbon Dioxide Capture and Storage. IPCC, 2007. Produced by Work Goup III. Cambridge University Press, Cambridge, UK, 442 pp. 
219. SOCOLOW, R.; PACALA, S. Stabilization Wedges: Solving the Climate Problem for the next $\mathbf{5 0}$ years with current technologies". Science Vol.305, pp 968 - 972. - 13 agosto 2004.

220. PRINCETON ENVIRONMENT INSTITUTE. The Stabilization Triangle: Tackling the Carbon and Climate Problem With Today's Technologies, Carbon Mitigation Initiative. Princeton University (2007). Disponível em: $<$ http:// www.princeton.edu/ cmi/resources/CMl Resources new files/ Wedges Concept Game Materials 2005.pdf> Acesso em: 9 out. 2009.

221. CUNHA, P., SARTORI, C., LOVATO, C. Desenvolvimento Tecnológico do Seqüestro de Carbono na PETROBRAS. $2^{\circ}$ Seminário Brasileiro sobre Seqüestro de Carbono e Mudanças Climáticas. Maceió, Brasil. 2008.

222. SOCOLOW, R.; PACALA, S. A Plan to keep carbon in check . Scientific American, Ano 5, edição Especial no53 , Outubro 2006, p.30-37

223. METEOROLOGIA AMBIENTAL. Composição da atmosfera da Terra. Disponível em: $<$ http://www.dca.iag.usp.br/www/material/mftandra/material/aca336/intro ga ses.pdf> Acesso em: 29 set. 2009.

224. EMPRESA DE CONSULTORIA AMBIENTAL. Composição do ar e impurezas. Disponível em:

$<$ http://www.consultoriaambiental.com.br/artigos/composicao do ar e imp urezas.pdf> Acesso em 29 set. 2009 .

225. HERZOG; GOLOMB, 2004 Herzog H. \& Golomb D. Carbon Capture and Storage from Fossil Fuel Use. Encyclopedia of Energy,Cambridge, MA: Massachusetts Institute of Technology, 2004, 19p.

226. DEPARTAMENT OF ENERGY. Carbon Sequestration Research and Development, DOE, 1999. Disponível em $<$ www.ornl.gov/carbon sequetration/ > Acesso em: 17 jun. 2005.

227. INTERGUBERNAMENTAL DE EXPERTOS SOBRE EL CAMBIO CLIMÁTICO. La captación y el almacenamiento de dióxido de carbono - Resumen para responsables de políticas y Resumen técnico. Informe especial del IPCC Grupo de Trabajo III- OMM / PNUMA, 2006.

228. INTERGOVERNMENTAL PANEL ON CLIMATE CHANGE. Special Report on Carbon dioxide Capture and Storage. Montreal, Canadá. IPCC, 2005. 
229. HOLLOWAY, S. Underground Sequestration of Carbon Dioxide - a Viable Greenhouse Gas Mitigation Option. 2005. Energy, 30(1112):2318-2333

230. SWINGLAND, lan R. Capturing Carbon and Conserving Biodiversity. Publisher Earthscan, 2003.

231. BACHU, S.; BONOJOLY, D.; BRADSHAW, J.; BURUSS, R.; MATHIASSEN, O. $\mathrm{CO}_{2}$ Storage capacity estimation: Methodology and gaps. International Journal of Greenhouse Gas Control, 2007. Vol. 1. pp. 430-443.

232. EUROPEAN COMISSION. Project Synopses: $\mathbf{C O}_{2}$ Capture and Storage Projects. Bélgica, 2007.

233. ROCHA, L. Experiências de Injeção de $\mathrm{CO}_{2}$ em Reservatórios de Petróleo do Recôncavo Baiano: Histórico e Perspectivas. Petrobras / UNBA. 1ํ Seminário Brasileiro de Seqüestro de Carbono e Mudanças Climáticas - Natal-RN - abril de 2007.

234. INTERGOVERNAMENTAL PANEL CLIMATE CHANGE. Special Report on Carbon Dioxide Capture and Storage. Preparado pelo Grupo de Trabalho III. Cambridge University Press, Cambridge, 2007, UK, 442 pp.

235. BENSON, S.M. Carbon Dioxide Capture for Storage in Deep Geological Formations. Monitoramento e Verificação. Berkeley , EUA. Cap.19, Elsevier, 2005.

236. SVENSSON, R., ODENBERGER, M., JOHNSSON F., STROMBERG, L. Transportation systems for $\mathrm{CO}_{2}$ - application to carbon capture and storage, 2004. Energy Conversion and Management,vol. 45, pp. 23432353.

237. INTERNATIONAL ENERGY AGENCY. Sequestro e captura de cabono em formações geológicas. IEA 2001. Disponível em<http://www.co2crc.com.au $>$ Acesso em: 15 dez. 2008.

238. FIGUEROA, J.D.; FOUT, T.; PLASYNSKI, S.; MCLLURIED, H.; SRIVASTAVA, R. D. Advances in $\mathrm{CO}_{2}$ Capture technology - The U.S. Department of Energy's Carbon Sequestration Program. 2008. International Journal of Greenhouse Gases control.2, pp.9-20.

239. YANG, H., $X U, Z$., FAN, M. Progress in carbon dioxide separation and capture: A review, Journal of Environmental Sciences, v. 20, pp. 14-27. 2008. 
240. THOMAS, D. C. Carbon Dioxide Capture for Storage in Deep Geologic Formations - Results from the $\mathrm{CO}_{2}$ Capture Project Capture and Separation of Carbon Dioxide from Combustion Sources. Volume 1.Berkeley, EUA. Editora Elsevier. 2006.

241. COOPERATIVE RESEARCH CENTRE. Greenhouse Gas Technologies. Injection and storage $\mathrm{CO}_{2}$. CO2/CRC. Disponível em: $<$ http://www.co2crc.com.au/aboutgeo/storage.html> Acesso em: 01 out. 2009.

242. INTERNATIONAL ENERGY AGENCY. IEA, 2001. Disponível em: $<$ http://www.co2crc.com.au > Acesso em : dez. 2008.

243. SUGUIO, K. Geologia sedimentar. São Paulo: Edgard Blucher $1^{\mathrm{a}}$ edição, 2003, $416 \mathrm{pg}$

244. GALE, J. Geological Storage of $\mathrm{CO}_{2}$ : What do we know, where are the gaps and what more needs to be done?, Energy, vol.29, pp. 1329-1338, 2004.

245. GUPTA, N., SASS, B., CHATTOPADHYAY, S., SMINCHAK, J., WANG, P., ESPIE, T. Geologic storage of $\mathrm{CO}_{2}$ from refining and chemical facilities in the Midwestern US, 2004, Energy, vol 29, pp. 1599-1609.

246. SVENSSON, R., ODENBERGER, M., JOHNSSON F., STROMBERG, L. Transportation systems for $\mathrm{CO}_{2}$ - application to carbon capture and storage, 2004, Energy Conversion and Management,vol. 45, pp. 2343-353.

247. BRADSHAW, J. Greenhouse Gas Storage Solutions. IPCC, 2007.

248. MOREIRA, J. R. Perfil dos projetos MDL. $3^{\circ}$ Congresso Brasileiro de Eficiência Energética - Workshop Mercado de Créditos de Carbono. Secretaria de Meio Ambiente Governo de São Paulo- São Paulo, 29 de Junho de 2006.

249. PARSONS, R . W. Handbook Geological Fundamentals- São Paulo, S.P. : Baker, 1. ed. 1997.

250. COTAÇÃO DO DÓLAR COMERCIAL. Disponível em: <http://economia.uol.com.br/cotacoes/>. Acesso em 4 out. 2009. 
251. TOLMASQUIN, M. TIOMNO (organizador), Fontes Renováveis de Energia, Rio de Janeiro. Interciência: Cenergia, 2003.

252. MACEDO, I. C. Estado da arte e tendências tecnológicas para energia. Brasília, DF: Centro de Gestão e Estudos Estratégicos, 2002. 90 p.

253. ROSILLO-CALLE, F.; BAJAY, S. V.; ROTHMAN, H. Uso da Biomassa Para Produção de Energia na Indústria Brasileira. 2005, Editora Unicamp.

254. HOOGWIJK, M.; DEN BROEK, R.; BERNDES, G.; FAAIJ, A. A review of assessments on the future of global contribution of biomass energy. In: World Conference on Biomass Energy and Industry, 1, 2000, Sevilla. London: James \& James, 2001.

255. COELHO, S.T.; GOLDEMBERG, J.; CORTEZ, L.A.B.; MACEDP, I.C. ; MOREIRA, J.R.; PALETTA,C.E.M.; WALTER, A.C.; BRAUNBECK, O.; HOFFMANN, R.; PRETZ, R. Geração de energia a partir da biomassa (exceto resíduos do lixo e óleos vegetais. In: TOLMASQUIM, M.T. (Org.). Fontes renováveis de energia no Brasil. Rio de Janeiro: Editora Interciência, pp. 1-90, 2003.

256. BATZIAS, F. A.; SIDIRAS, D. K.; SPYROU, E. K. Evaluating livestock manures for biogas production: a GIS based method. Renewable Energy, Oxford, v. 30, n. 8, p.1161-1176, 2005.

257. CORTEZ, L. A.; LORA, E. S.; GÓMEZ, E. O. Biomassa para energia. Campinas, S. P.: Editora da Unicamp, 2008. 736 p. v.1.

258. GAZZONI, D. L. Empresa Brasileira de Pesquisa Agropecuária - Centro Nacional de Pesquisa de Soja - Universidade Federal do Rio Grande do Sul, UFRGS, Brasil.

259. COELHO, S.T.; MARTINS, S.; SANTOS, S. M. A. O Estado da Arte da Gaseificação. Comparação entre Tecnologias de Gaseificação de Biomassa existentes no Brasil e no Exterior e Formação de Recursos Humanos na região Norte. Centro Nacional de Referência em Biomassa (CENBIO), 2002.

260. LORA, E. S. ; ANDRADE, R. V. Estado da arte e potencial de utilização dos biocombustíveis no Brasil . Biomassa Energia, Viçosa, Brasil, v. 2, n. 1, p. 19-36, 2006. 
261. JENKINS, B. M., Bioenergy, Biofuels; and Potentials for Sustainable Development. Março, 2007. Energy Lecture Series, Department of Biological and Agricultural Engineering; 14 de março, 2007. Disponível em: $<$ http://bioenergy.ucdavis.edu/materials/Presentations/Jenkins\%20031407 \%20-\%20EnergyLecture Biofuels.pdf>. Acesso em 24 set. 2009.

262. CIFERNO, J. P.; MARANO, J. J. Benchmarking Biomass Gasification Technologies for Fuels, Chemicals and Hydrogen Production. Departamento de Energia dos Estados Unidos e National Energy Technology Laboratory. Junho, 2002.

263. CRAIG, K, R.; MANN, M. K. Cost and Performance Analysis of Three Integrated Biomass Gasification Combined Cycle Power Systems. National Renewable Energy Laboratory. 2000.

264. WALTER, A.C.S. New Technologies for Modern biomass Energy Carries, Industrial Uses of Biomass Energy - The example of Brazil, Taylor \& Francis, London, 2000.

265. DASAPPA, P. J.; PAUL, H. S.; MUKUNDA, N. K. S.; RAJAN, G. S; SRIDHAR, $H$. V. - Biomass gasification technology - a route to meet energy needs - CURRENT SCIENCE, VOL. 87, NO. 7, 10 OCTOBER 2004 P 908 A 916 - Department of Aerospace Engineering, 1Centre for Sustainable Technologies, Indian Institute of Science, Bangalore 560 012, India.

266. CORTEZ, L. A. B.; LORA, E.S. Tecnologias de Conversão Energética da Biomassa. Manaus: EDUA/EFEI.1997, 540 p.

267. BIOMASS TECHNOLOGY GROUP. Gasification. The pyrolysis and combustion .BTG. Disponível em: < www.btgworld.com >. Acesso em 14 out. 2009.

268. MOREIRA, J. M.; RUGGERO P. A. Efeitos da Utilização da Energia de Biomassa sobre o Meio-Ambiente.

Disponível em:

$<$ http://www.fem.unicamp.br/ em313/paginas/gaseif/gaseif.html.>. Acesso em 30 jan. 2009.

269. LORA, E. S.; VENTURINI, O. J. Biocombustíveis. Rio de Janeiro, R.J.: Interciência, 2008.

270. IAQUANIELLO,G.; MANGIAPANE, A. Integration of biomass gasification with MCFC. International Journal of Hydrogen Energy 31, 2006, p 399-404. 
271. USHIMA, A. H. "Aspectos tecnológicos de gaseificadores e sistema de limpeza de gases". Centro Nacional de Referência em Biomassa (CENBIO), 2002.

272. WINROCK, S. Trade Guide on Renewable Energy in Brazil, International Guide. Brazil, Salvador, Bahia, October, 2002.

273. THE BIOMASS ENERGY FOUNDATION PRESS. GENGAZ. Disponível em $<$ http://www.gengas.nu/byggbes/index.shtml $>$. Acesso em 08 out. 2005.

274. VAN SWAllJ, W.P.M. Gasification, the process and the technology, Resources and Conservation, v.7, p. 337-349, 1981

275. SÁNCHEZ, C.G. Estudo da volatilização e da gaseificação de biomassa em leito fluidizado, Tese (Doutorado) - Faculdade de Engenharia Mecânica, UNICAMP. Campinas, 1994.

276. LORA, E. S. ; ANDRADE, R. V. ; GOMEZ, E. O. ; SALES, VILAS, C. A. ; MELO, B. A.; SAUVANELL, A. L. B. ; MERENCIO, D.O. . Principales resultados de los proyectos en gasificación de biomasa en el Nucleo de Excelencia en Generación Termoeléctrica y Distribuida de la Universidad Federal de Itajubá en Brasil. Biomassa \& Energia (Viçosa), v. 03, p. 36-47, 2006.

277. USHIMA, A. H. Modelagem e simulação de pirólise e secagem de biomassa em um gaseificador de leito contracorrente. 1996. Tese (Mestrado) - Universidade Estadual de Campinas, Faculdade de Engenharia Mecânica, 2 vol, pp. 158, 1996.

278. REED, T. B.; GAUR, S. A. A. Survey of Biomass Gaseification 2000. The National Renewable Laboratory and The Biomass Energy Foundation, 2001

279. REED, T. B.; GRABOSKI, M. S.; LEVIE, B. Fundamentals, development \& scale - up of the air-oxygen stratified downdraft gasifier. Biomass Energy Foundation Press, 1994.

280. AHMED, I.; GUPTA A. K. Syngas yield during pyrolisis and steam gasification of paper. Applied energy 86 (2009) 1813-1821

281. NETL - GASIFICATION WORD DATABASE. Current Industry Status. U. S. Department of Energy Office of Fossil Energy National Energy Technology laboratory, 2007. Disponível em: $<$ http://www.netl.doe.gov/techonologies/coalpower/gasification/database/ga sification2007 web.pdf $>$. Acesso em 05 Jan 2008 > 
282. MUKUNDA, H.S.; DASAPPA, S.; PAUL, P. J.; RAJAN, N. K. S.;

SHRINIVASA; U.; Gasifiers and combustors for biomass - technology and field studies. Department of Aerospace Engineering, Indian Institute of Science, Bangalore, India. Energy for Sustainable Development I Volume I No. 3 I September 1994.

283. BOWEN, D, LAU R., ZABRANSKY, R., REMICK, R., SLIMANE, S., DOONG. Techno-Economic Analysis of Hydrogen Production by Gasification of Biomass Hydrogen, Fuel Cells, and Infrastructure Technologies FY 2003 Progress Report. Disponível em: $<$ http://www1.eere.energy.gov/hydrogenandfuelcells/pdfs/iib5 bowen.pdf > Acesso em 15 mar. 2009.

284. LORA, E. S.; SALOMON, K.R. Estimate of ecological efficiency for thermal power plants in Brazil. Energy Conversion and Management, Elsevier Ltd, Holanda, v. 46, p. 1293-1303, 2005.

285. WALDHEIM, L. Overview of Gasification of Biomass. TPS Termiska Processer. Piracicaba, São Paulo Setembro, 2005.

286. WOODS, J.; HALL, D. O. Bioenergy for development: technical and environmental dimensions. Rome: Organização das Nações Unidas para a Agricultura e Alimentação (FAO),1994. (Environment and Energy. Paper 13).

287. U. S. DEPARTMENT OF ENERGY. Current perspective on gasification plants around the word. National Energy Technology Laboatory, 2006. $25 p$.

288. COELHO, S.T. Avaliação da cogeração de eletricidade a partir de bagaço-de-cana em sistemas de gaseificador/turbina a gás. 148 p + anexos. Dissertação (Mestrado). Programa Interunidades de PósGraduação em Energia da Universidade de São Paulo - PIPGE/ USP, 1992.

289. LORA, E. S.; HADDAD, J. Geração Distribuída - Aspectos Tecnológicos, Ambientais e Institucionais. Rio de Janeiro, R.J.: Interciência, 2006. 240 p.

290. LORA, E. S.; NASCIMENTO, R. M. A. Geração Termelétrica Planejamento, Projeto e Operação. Rio de Janeiro, R.J.: Interciência MME/EFEI, 2004. 1269 p. v. 2.

291. NEIVA, A.C.B. Estudo de alimentadores de Bagaço de Cana para Reatores Atmosféricos, Dissertação de Mestrado, Faculdade de Engenharia Mecânica, UNICAMP. Campinas, 1998. 
292. FERNANDES, M.C., SÁNCHEZ, C.G. Economic Viability of a Biomass Gasification Power Plant for Rural Electrification. In: CleanAir V - fifth international conference on technologies and combustion for a clean environment, .Lisboa. July, 1999.

293. FERNANDES, M.C. Avaliação Tecno-econômica da Gaseificação do Capim-elefante para Eletrificação Rural, Dissertação de Mestrado, Faculdade de Engenharia Mecânica, UNICAMP. Campinas, 2000.

294. BEHAINNE, J.J.C. Diminuição de $\mathrm{H}_{2} \mathrm{~S}$ na gaseificação de carvão mineral mediante adição de dolomita em reator de leito fluidizado. Tese de Mestrado, Faculdade de Engenharia Mecânica, UNICAMP. Campinas, 1999.

295. MUKUNDA, H.S., DASAPPA, S., SHRINIVASA, U. Open-top Wood Gasifiers. In: JOHANSSON, T.B. Renewable Energy - Sources for Fuels and Electricity. London: Earthscan, 1992. Cap.16, p.699-727.

296. ROCHA, B. R. P.; MONTEIRO, C.; SILVA, I. M. O. Uso de briquetes compostos para produção de energia no Estado do Pará. AGRENER, 2002. Quarto encontro de energia no Meio Rural, out. 2002, Campinas SP.

297. WENDER, I. Reactions of synthesis gas. Fuel Processing Technology, V.48, n.3, p.189-297, 1996.

298. GAO, NINGBO; LI, AIMIN; QUAN, CUI; GAO, FAN. Hydrogen-rich gas production from biomass steam gasification in an updraft fixed-bed gasifier combined with a porous ceramic reformer. International Journal Of Hydrogen Energy 33, May. 2008.(Elsevier, 5430 - 5438)

299. BERNARDI, P. J. Alternativas para a produção de hidrogênio nas regiões brasileiras visando a geração de energia elétrica distribuída. IPEN - USP. São Paulo, S.P. 2009.

300. LEE, JAMES.W.; LI,RONGFU Integrations of fossil energy systems with $\mathrm{CO}_{2}$ sequestration through $\mathrm{NH}_{4} \mathrm{HCO}_{3}$ production. Energy Conversion and management - 44, p. 1535 - 1546, 2003.

301. BAI, HSLUNLING, YEH, C. AN. Removal of $\mathbf{C O}_{2}$ greenhouse gas by ammonia scrubbing. Institute of Environmental, National Chiao, Tung University. 1997, 36, 2490-2493 
302. COELHO, A. M., RIBEIRO, B., RESENDE, A., TEIXEIRA, G. Eficiência Agronômica do Cloreto de Amônio e Bicarbonato de Amônio Como Fontes de Nitrogênio Para a Cultura do Milho. Comunicado Técnico 136, Embrapa, 2006. Sete Lagoas, MG. In: Congresso nacional de milho e sorgo, 26: Embrapa Milho e Sorgo, 2006.

303. ZHANG, Z. Research on physical chemistry characters and production increasing mechanisms of long effective ammonium bicarbonate. China Science (B), 1996, 26, 453.

304. LIU, J.; WAMG, S.; ZHAO, B.; TONG, H. CHEN, C. Absorption of carbon dioxide in aqueous ammonia. Energy procedia. Elsevier. 903-940 (2009).

305. CHINA NATIONAL CHEMICAL. Handbook of chemical engineering art and design. Shangai: China National Chemical Engineering Industry Press, 1955. p. 722

306. XI, Z.; SHI, X.; LIU, M.; CAO, Y.; WU, X.; RU. G. Agrochemical properties of ammonium bicarbonate. Turang Xuebao, 1985, 223-232

307. PLUMMER, L. N.; PAKHURST, D. L. Development of reaction models for ground-water systems. Geochim Cosmochim Acta. 665-668 (1983).

308. BROOKS, L. A.; AUDRIET, L. F. Ammonium Carbamate. Inorganic Synthesis. 1946. 2-85.

309. BROOKS, R. Manufacture of ammonium bicarbonate. British Patent 742 , 386, 1953.

310. HATCH, T. F.; PIGFORD, R. L. Simultaneous absorption of carbon dioxide and ammonia in water. Industrial Chemical Engineering Fundaments, 1962, 1, 209.

311. SHALE, C. C.; SIMPSON, D. G.; LEWIS, P. S. Removal of súlfur and nitrogen oxides from stack gases by ammonia. Chemical Engineering Programme Symposion. 1971. 52-67.

312. KOUTINAS, A. A.; YIANOULIS, P.; LYCOURGHIODS, A. Industrial scale modelling of the thermochemical energy storage system based on $\mathrm{CO}_{2}$ $+2 \mathrm{NH}_{3}-\mathrm{NH}_{2} \mathbf{C O O N H} \mathrm{N}_{4}$ equilibrium. Energy Conversion Manage. 1983, 23-55.

313. NEEFF, T. Guidebook to markets and commercialization of CDM projects. Turrialba, C.R : CATIE, 2007. 42 p. - (Serie técnica. Manual técnico / CATIE ; no. 65). 
314. BRASIL. MME - Ministério das Minas e Energia. BEN -Balanço Energético Nacional 2000: Ano Base 2007. Rio de Janeiro, EPE - Empresa de Pesquisa Energética.

315. YARA. Cotação do Mercado Internacional de Fertilizantes - Disponível em:

$<$ http://www.yara.com/en/investor relations/analyst information/fertilizer pri ces/index.html. . . Acesso em 19 Fev. 2009.

316. ENVIRONMENTAL BROKERS. Cotação do Mercado Internacional de Créditos de Carbono - Disponível em: <http://www.emitmarkets.com/?gclid=CMzispWLy5KCFQKHxwodrWWsuw..$>$ Acesso em 30 Mar. 2009.

317. MENG, L.; BURRIS, S.; BUI, H.; PAN, W. Development of na analytical method for distinguishing ammonium bicarbonate from the products of an aqueous ammonia $\mathrm{CO}_{2}$ srubber. Analytical Chemistry, Vol. 77, No. 18, September 15, 2005.

318. MITSUBICHI FINANCIAL GROUP. UFJ, 2008. Disponível em: $<$ http://money.cnn.com/magazines/fortune/global500/2008/snapshots/1103 2.html. $>$ Acesso em: 04 nov. 2009

319. NAKAMOTO, K. Infrared and Raman Spectra of Inorganic and Conduction Compounds. New York: John Wiley \& Sons, 3. ed, 1986.

320. KUCHERYAVIY, V. I.; GORLOVSKII, D. M. Densities of coexisting phases in the equilibrium gas-liquid system $\mathrm{NH}_{3}-\mathrm{CO}_{2}-\mathrm{CO}-\left(\mathrm{NH}_{2}\right)_{2}-\mathrm{H}_{2} \mathrm{O}$ at high temperatures and pressures. Zh. Prikl. Khim. 1970, 43, 1675.

321. DIAO, Y.; ZHENG, X.; HE, B.; CHEN, C.; XU, C. Experimental study on capturing $\mathrm{CO}_{2}$ greenhouse gas by ammonia scrubbing. Energy Conversion and Management. Vol. 45, Issues 13-14, August 2004, Pages 2283-2296

322. MERCK, K. Reagents chemicals diagnostics; Iriodin / Afflair: Darmstadt, Germany, 1996.

323. PELKIE, J. E.; CONCANNON, P. B.; MANLEY, D. B.; POLING, B. E. Product distributions in the $\mathrm{CO}_{2}-\mathrm{NH}_{3}-\mathrm{H}_{2} \mathrm{O}$ system from liquid conductivity measurements. Ind. Eng. Chem. Res. 1992, 31, 2209.

324. KOUBSKY, P.; HLADKY, V. Equilibrium calculations in the system $\mathrm{NH}_{3}-\mathbf{C O}_{2}-\mathbf{H}_{2}$ O. Int. Chem. Eng. 1976, 16, 392 